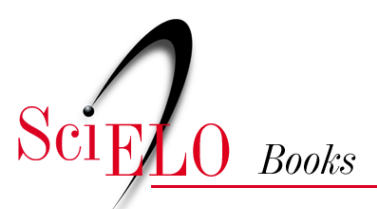

\title{
Análise estratégica em saúde e gestão pela escuta
}

\author{
Francisco Javier Uribe Rivera
}

\section{SciELO Books / SciELO Livros / SciELO Libros}

RIVERA, F.J.U. Análise estratégica em saúde e gestão pela escuta [online]. Rio de Janeiro: Editora FIOCRUZ, 2013, 309 p. ISBN: 978-85-7541-303-6. https://doi.org/10.7476/9788575413036.

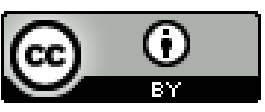

All the contents of this work, except where otherwise noted, is licensed under a Creative Commons Attribution 4.0 International license.

Todo o conteúdo deste trabalho, exceto quando houver ressalva, é publicado sob a licença Creative Commons Atribição 4.0. 


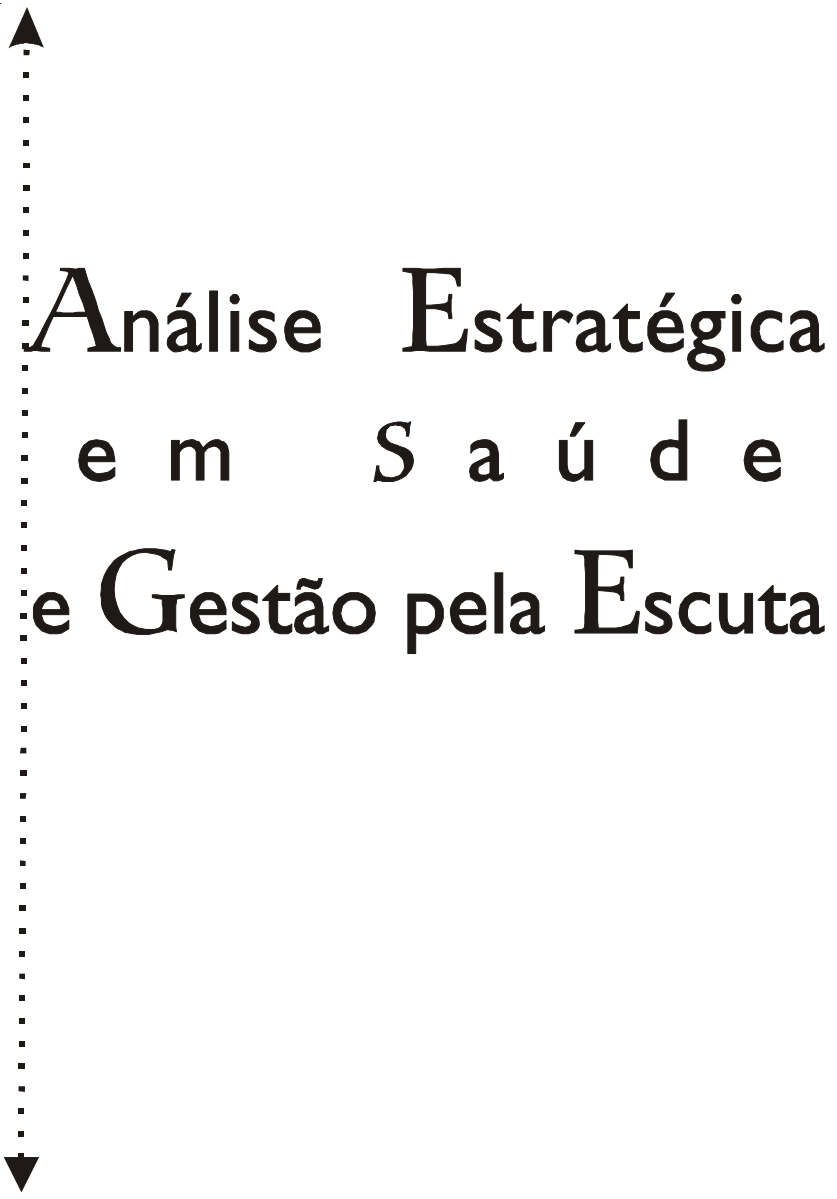




\title{
FUNDAÇÃO OSWALDO CRUZ
}

Presidente

Paulo Marchiori Buss

Vice-Presidente de Desenvolvimento Institucional, Informação e Comunicação

Paulo Gadelha

\section{EDITORA FIOCRUZ}

\author{
Coordenador \\ Paulo Gadelha
}
Conselho Editorial
Carlos E. A. Coimbra Jr.
Carolina M. Bori
Charles Pessanha
Jaime L. Benchimol
José da Rocha Carvalheiro
José Rodrigues Coura
Luis David Castiel
Luiz Fernando Ferreira
Maria Cecília de Souza Minayo
Miriam Struchiner
Paulo Amarante
Vanize Macêdo

Coordenador Executivo

João Carlos Canossa P. Mendes 


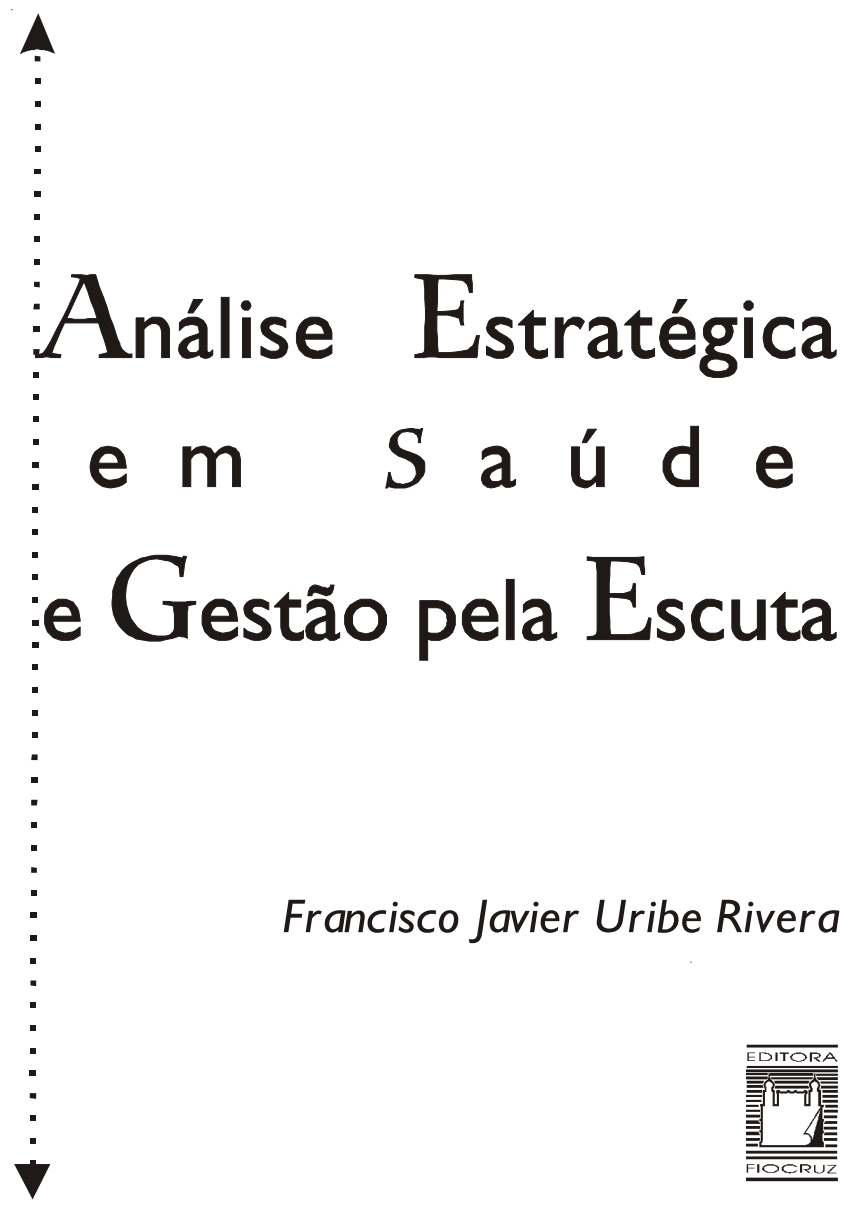


Copyright (C) 2003 by Francisco Javier Uribe Rivera

Todos os direitos desta edição reservados à

FUNDAÇÃO OSWALDO CRUZ / EDITORA

ISBN: 85-7541-027-X

Capa, Projeto Gráfico: Carlota Rios e Gordeeff

Editoração Eletrônica: Ramon Carlos de Moraes

Revisão, copidesque e padronização de originais: Fernanda Veneu

Catalogação-na-fonte

Centro de Informação Científica e Tecnológica

Biblioteca Lincoln de Freitas Filho
U76a Uribe rivera, Francisco javier
Análise Estratégica em Saúde e Gestão pela Escuta/
Francisco Javier Uribe Rivera. Rio de Janeiro : Ed Fiocruz, 2003.
312p., tab

1. Planejamento Estratégico. 2. Administração Hospitalar

3. Planejamento em Saúde

CDD- 20.ed. - 362.10425

2003

EDITORA FIOCRUZ

Av. Brasil, 4036 - 10 andar - sala 112 - Manguinhos

21041-361 - Rio de Janeiro - RJ

Tels: (21) 3882-9039 e 3882-9041

Telefax: (21) 3882-9006

e-mail: editora@fiocruz.br

$\mathrm{http}: / / \mathrm{www} \cdot$ fiocruz.br 


\section{Colaboradores}

Elizabeth Artmann.

Assistente social, sanitarista, doutora em Saúde Coletiva pela Faculdade de Medicina da Universidade Estadual de Campinas (Unicamp), pesquisadora adjunta de Saúde Pública da Ensp/Fiocruz.

\section{Fernando Augusto de Cunha Ramos.}

Médico, especialista em Psiquiatria (IPUB/UFRJ), especialista em Gestão Hospitalar (Ensp/Fiocruz), ex-diretor do Hospital Philippe Pinel (RJ), onde atualmente coordena a Residência Médica.

\section{Liliane Mendes Penello.}

Médica, especialista em Psiquiatria e Psicoterapia Analítica de Grupo, especialista em Gestão Hospitalar (Ensp/Fiocruz), funcionária do Ministério da Saúde, exdiretora do Hospital Philippe Pinel (RJ). 


\section{SUMÁRIO}

Apresentação

I. Planejamento e Gestão em Saúde: flexibilidade metodológica e agir comunicativo

Francisco Javier Uribe Rivera

Elizabeth Artmann

2. Análise Estratégica Hospitalar e Projeto Assistencial:

a perspectiva de Michel Crémadez e François Grateau

Francisco Javier Uribe Rivera

3. Aplicação da Démarche Stratégique ao Hospital

Philippe Pinel: pensando em rede

Fernando Augusto de Cunha Ramos

Liliane Mendes Penello

Francisco Javier Uribe Rivera

4. Análise Estratégica e Prospectiva em Saúde: o enfoque de Godet e simulações de cenários para o Programa de Saúde da Família (PSF) I5I

Francisco Javier Uribe Rivera

5. Cultura e Liderança Comunicativa

Francisco Javier Uribe Rivera

6. Comunicação e Negociação Gerencial

Francisco Javier Uribe Rivera

7. (Inter)subjetividade, Aprendizagem Organizacional

e Mudança: algumas ferramentas lúdico-pragmáticas

Francisco Javier Uribe Rivera 


\section{Apresentação}

Reúne-se, aqui, uma série de trabalhos cujo fio condutor representa uma proposta teórico-metodológica de gestão, traduzida no título: Análise Estratégica em Saúde e Gestão pela Escuta. Estes estudos ganham coerência em relação ao passado ou por oposição ao passado. Representam um desdobramento de nossa tese de doutoramento em Saúde Pública, defendida em 1991 na Escola Nacional de Saúde Pública da Fundação Oswaldo Cruz (Ensp/Fiocruz), que consistiu em um contraponto teórico-metodológico entre a Teoria do Agir Comunicativo de Habermas e a Teoria do Planejamento Estratégico em Saúde. Naquele momento, fomos animados pelo propósito de (des)construir o enfoque de planejamento estratégico, através de uma análise crítica sistemática, alicerçada na idéia do planejamento como uma relação interativa dialógica, superadora da lógica da utilidade individual e da reificação dos outros atores. Essa crítica não objetivou, porém, a negação radical dos métodos conhecidos de planejamento estratégico, especialmente do enfoque situacional de Matus, mas um alargamento de perspectiva, na direção de uma maior flexibilidade metodológica, resgatando o planejamento a serviço da criação de um ambiente de comunicação ampla, da busca por legitimidade e do consenso na construção das propostas pertinentes.

A tese teve um escopo eminentemente teórico de refletir, no interior do campo do planejamento e da gestão, um novo paradigma, o comunicativo. A partir de então, conscientes de que a crítica teórica é necessária, porém insuficiente em um campo pragmático, emerge o propósito de realizar um trabalho propositivo que implicasse dar um conteúdo prático a uma proposta de agir comunicativo em gestão e planejamento. Tal propósito não tem sido fácil de realizar, pois subentende o estabelecimentos de mediações, de pontes, entre o nível mais epistemológico da grande teoria e a especificidade do terreno da gerência. Este esforço comporta a busca de autores e de enfoques do campo respectivo que possam ser utilizados como fatores de articulação e ser identificados como expoentes da gestão como intersubjetividade discursiva e como 
processo de desenvolvimento da aprendizagem, da solidariedade e de nexos ou redes criativas. Isto quer dizer que não é possível deduzir mecanicamente ou linearmente do agir comunicativo uma proposta prática. Esta só se configura como uma diversidade pragmática de enfoques que podem ser aproximados dos pressupostos gerais desse paradigma comunicativo.

A docência sistemática na pós-graduação da Ensp nos ensejou uma disciplina de pesquisa e reflexão que nos permitiu apreender autores e enfoques, os quais pudemos aglutinar dentro de nosso referencial. Alguns foram testados ou experimentados junto aos alunos dessa casa e algumas dessas experiências queremos trazer à tona no livro. Estes alunos foram a condição de possibilidade de alguns capítulos. Podem ser chamados quase co-autores, em alguns momentos, e a eles agradecemos. $\mathrm{O}$ trabalho de pesquisa, articulado à docência, é lento, cumulativo e demanda tempo. É uma tentativa permanente de dissipar os traços de escuridão inerentes ao experimentar com idéias em prol de mais luz. Isto, somado aos altos e baixos da vida, explica o lapso de tempo ao trazer à tona os resultados deste trabalho nesta publicação e porque não atingimos completamente este propósito. Vale dizer que o trabalho de pesquisa com idéias é permanente e contínuo.

Os autores principais que fomos solidificando nesse nosso processo relativamente sistemático, às vezes intuitivo, de apreensão das identificações discursivas, são, principalmente Matus, Crémadez, Godet e Senge.

Carlos Matus, grande ideólogo do planejamento latinoamericano, falecido há pouco tempo, nos ensinou a arte de pensar mais pragmaticamente o planejamento como gerência descentralizada de problemas abordados criativa e interativamente, bem como as regras de como pensar estrategicamente uma organização. É o autor que mais pudemos abarcar e conhecer, e que mais marcas deve ter deixado no nosso imaginário mais profundo. Ele não é o motivo principal deste trabalho, mas a ele dedicamos as primeiras linhas, no primeiro capítulo, pois é a partir das lacunas/possibilidades que nele identificamos, iluminados pelo Agir Comunicativo de Habermas, que desenvolvemos a pesquisa de outros autores e perspectivas que pudessem complementar sua abordagem, preenchendo os vazios e possibilidades de comunicação. Sua produção profícua é mais do que suficiente e nos leva naturalmente à busca de novos autores que ampliem o perfil de sua obra, como parte deste nosso trabalho de pesquisa. Devemos frisar aqui que o legado de Matus é um patrimônio inexorável nesta área que é o nosso campo de reflexão e de prática.

Michel Crémadez, de uma equipe francesa de gestão estratégica (de Altos Estudos Comerciais), é o segundo autor que conhecemos com maior profundidade relativa. À sua obra teórico-prática e a seus desdobramentos, dedicamos 
uma parte significativa do livro (dois capítulos). Crémadez e François Grateau ex-diretor do Centro Regional Hospitalar Universitário de Lille (CHRU) - são os responsáveis pelo desenvolvimento da démarche stratégique em saúde, na área hospitalar. Este enfoque foi trazido por nós do CRHU de Lille, em razão de um estágio que fizemos lá como parte de uma política de colaboração entre a Ensp/Fiocruz, brasileira, e a Ensp francesa.

O CHRU é uma holding hospitalar, de natureza pública, que opera como referência para todo o norte da França e parte da Bélgica. Este enfoque foi adaptado por nós à realidade brasileira, respeitando o rigor dos princípios e da metodologia originais, e aplicado em vários hospitais públicos do Brasil.

Existem algumas diferenças entre a realidade francesa e a brasileira. $\mathrm{Na}$ França, o que é publico é parte do sistema hospitalar, não assim o sistema ambulatorial. No Brasil, o sistema ambulatorial é predominante público e, na área hospitalar, há uma predominância do setor privado, embora o público tenha um papel de destaque acima de tudo no que diz respeito à alta complexidade e, por outro lado, parte importante do setor privado se encontre sob a regulação do público, atendendo à clientela do Sistema Único de Saúde, e sendo financiado parcialmente com recursos públicos.

O que diferencia as realidades vividas nos dois países de maneira mais significativa é o fato de, na França, haver uma oferta hospitalar mais saturada, configurando situações mais claras de concorrência - entendida como superposição de atividades e descoordenação (que se traduzem em disputa de recursos e/ou de clientela). Nesse contexto, a aplicação da démarche é mais claramente justificável ou necessária. No Brasil, haveria menos recursos relativos e, em alguns espaços geográficos (não os grandes centros urbanos densamente povoados), identificamos situações de monopólio ou de poucas estruturas hospitalares, sem concorrência. Estas situações dificultariam a aplicação da démarche como método de coordenação ou de regulação da concorrência. No entanto, não a invalidam completamente. Simular a concorrência nestes casos é o conselho que se dá para aplicar a démarche como perspectiva de análise que visa a melhorar os níveis de qualidade pré-existentes.

Outro elemento do contexto que favoreceria a aplicação do enfoque na França corresponde à obrigatoriedade normativa de que os hospitais formulem projetos de estabelecimento para negociar entre si e com a regulação dentro da perspectiva da regionalização( das agências regionais de hospitalização criadas em fins da década de 90 e início do ano 2000). No entanto, o avanço recentemente experimentado pelo Brasil no desenho de uma política de regionalização, que compense os problemas decorrentes da municipalização radical da década de 90 (Norma Operacional da Assistência à Saúde NOAS-SUS 01/02. Portaria MS/GM n³73, de 27/01/2002. Brasília -DF), cria condições para a 
instauração de uma lógica de formulação de projetos como componentes do processo de negociação de redes micro e macrorregionais.

Podemos assinalar que a partir de nossa experiência de aplicação do enfoque no Brasil avançamos expressivamente no domínio do mesmo, justamente porque ele se transformou numa realidade prática, fomentando novos trabalhos também acadêmicos. Neste livro, extraímos e apresentamos o que nos parece fundamental da obra dos autores, fazendo nossas próprias análises e comentários. Acrescentamos um caso elaborado com alunos do curso de Gestão Hospitalar da Ensp, a partir de um exercício didático de aplicação da metodologia a um hospital do Rio de Janeiro; Hospital Philippe Pinel, e o roteiro de aplicação desta forma de análise estratégica. O que tem de comunicativo nesta proposta, é o objetivo geral de transformar situações de concorrência em colaboração, de gerar projetos integrados e solidários por serviço que compensem a diferenciação, o postulado organizacional de redes de exploração de transversalidades internas e externas aos hospitais, e a sua implementação participativa e dialógica, de baixo para cima, como lugar de comunicação permanente. É essencial ao enfoque a observância de algumas características culturais das organizações profissionais, como a grande autonomia operacional dos centros assistenciais. Tendo em vista a escuta desse padrão cultural, o enfoque procura o maior envolvimento dos atores de base e a criação de elos de ligação entre o estratégico e o operacional, através de uma comunicação intensiva entre a direção e os profissionais.

A seguir, o outro autor que perfilamos no livro é Michel Godet, francês, um dos autores que trabalha com análise prospectiva de maior renome internacional. A prospectiva e a construção de cenários configuram uma das dimensões mais inestruturadas da gestão e um campo ainda ser melhor explorado. Esta natureza da prospectiva não é motivo para evitar o tema. A gestão e o planejamento não são possíveis sem uma visão do futuro, dos cenários futuros. Esta necessidade inexorável define uma das características que diferenciam o planejamento estratégico do normativo, como aprendemos com Matus.

A metodologia de Godet chama a atenção e se impõe pelo seu grau de formalização interna e pelo fato de aliar uma lógica de análise qualitativa dos atores sociais e uma lógica mais matemática de probabilização de tendências a partir de um sistema de consulta ampla a especialistas. Este enfoque não é novo. Porém, é permanentemente novo o desafio de aplicá-lo criativamente com as adaptações necessárias à área da saúde. O nosso objetivo é apresentá-lo com esse espírito de inovação e de levantamento de alternativas instrumentais.

Assim sendo, o protocolo de trabalho do autor será objeto de um capítulo particular de acordo com a nossa leitura do mesmo e contraposto a visões mais qualitativas e simplificadas de técnica de cenários. Vários casos trabalhados com 
alunos no âmbito do Programa de Saúde da Família (PSF) serão inseridos no intuito prático de possibilitar a apreensão de sua lógica. O aspecto comunicativo nesta visão da prospectiva está representado pela tentativa prática de reduzir a subjetividade imanente à leitura do futuro através da consulta ampla a especialistas e da exploração da possibilidade do consenso entre eles, mesmo que entre eles não se estabeleça uma relação dialógica direta.

Comunicativo é o espírito da oficina de trabalho participativa de pares e de atores externos, costurando acordos sobre o que será essencial no futuro e sobre suas implicações práticas para o desenho da ação presente. Comunicativo é o uso que, de acordo com Senge, pode ser feito da narrativa do futuro com um meio de trazer a tona os modelos mentais dos atores envolvidos nessa narrativa e o diálogo que pode se estabelecer sobre esses modelos particulares, visando a alinhar a visão através da reflexão crítica desses materiais.

Peter Senge é o autor que conhecemos mais recentemente. Ele nos trouxe também um certo dom da simplicidade. Representando a corrente americana e internacional da learning organization, este autor nos traz uma importante metáfora: a do entendimento da organização como uma sociedade ou intersubjetividade em processo permanente de aprendizagem. Como sistema que aprende, a organização dependeria, para ter êxito, do desenvolvimento, por parte dos seus membros, das habilidades de reflexão, de interação, de indagação e de argumentação necessárias à transferência de símbolos e capacidades inerentes ao aprender mesmo. Esta corrente está diretamente ligada à visão da organização como processo lingüístico e de comunicação.

Nosso objetivo é estabelecer nexos entre intersubjetividade e gestão desde a perspectiva da aprendizagem e apresentar instrumentos e propostas de aprendizagem organizacional que potencializem mudanças. Esta corrente incorpora temáticas que fazem parte de maneira mais típica de uma forma de gerir que supõe uma ausculta cultural permanente e o exercício de uma liderança comunicativa, de apoio sistemático à capacidade coletiva de aprendizagem. Está extremamente próxima das temáticas que constituem o objeto dos últimos três capítulos sobre gestão pela escuta: cultura, liderança comunicativa e negociação.

O pano de fundo é o conceito de liderança como possibilidade intersubjetiva de desenvolvimento do consenso necessário ao andamento produtivo de uma organização e à promoção das mudanças que se tornam pertinentes. Dos autores que trabalham o conceito de liderança (alguns apresentados aqui, especialmente nos capítulos cinco e sete), retiramos a idéia básica de que as principais habilidades da mesma são a visão estratégica que se articula à capacidade de refletir o futuro e à capacidade de mediar coletivos e subjetividades.

O título deste livro, Análise Estratégica em Saúde e Gestão pela Escuta, expressa o desejo de oferecer materiais de análise e de utilidade prática que possam 
ajudar a incentivar o desenvolvimento da liderança individual e coletiva. A publicação representa, através de sua proposta, a tentativa de apresentar mais uma referência para o treinamento de habilidades típicas da liderança. A gestão pela escuta acentua a necessidade de uma liderança que se desenvolva a partir de uma escuta da cultura, de uma capacidade aumentada de negociação cooperativa e de um poder de comunicação a serviço, preferencialmente, do crescimento do coletivo.

No primeiro capítulo, em co-autoria com Elizabeth Artmann, atualizamos nosso mapeamento de tendências neste campo e dos desafios em termos de pesquisa para complementar o referencial do planejamento estratégico-situacional, de maneira a construir um substrato prático para a gestão comunicativa. Esta discussão é uma atualização de um artigo já publicado em 1999, na Revista Ciência \& Saúde Coletiva, da Associação Brasileira de Pós-Graduação em Saúde Coletiva (Abrasco).

No segundo capítulo, apresentamos a proposta teórico-metodológico de Michel Crémadez, que se notabiliza pelo esforço de transformação de uma lógica do planejamento estratégico corporativo em um sistema de gestão estratégica para hospitais do setor público e privado, que contribua para uma avaliação sistemática da missão em função de uma perspectiva que privilegia os usuários do sistema e a composição de redes.

O capítulo três representa o resultado de um exercício de aplicação do enfoque da análise estratégica hospitalar francesa ao Hospital Philippe Pinel, cujo autor principal foi o então diretor do hospital e aluno da Ensp, Fernando Augusto de Cunha Ramos, do Curso de Gestão Hospitalar (1997).

No quarto capítulo apresentamos, discutimos e aplicamos o modelo de análise de Godet, e outras aproximações à questão dos cenários de cálculo prospectivo.

Os capítulos cinco, seis e sete representam um conjunto de textos de nossa autoria cujo fio condutor é a gestão pela escuta. Destacamos, em cada um, questões específicas pertinentes ao tema.

No primeiro deles, no capítulo cinco, apresentamos vários enfoques de análise cultural, incluindo uma discussão sobre a perspectiva de mudança cultural e de análise do conceito de liderança, privilegiando uma concepção comunicativa da mesma, que se articula à possibilidade de mudança cultural.

O sexto capítulo representa um enfoque geral de negociação cooperativa consagrado por autores como Fischer e Ury da escola de Negociação de Harvard - onde destacamos a necessidade da utilização de ferramentas de comunicação que provêm de âmbitos variados, como a própria psicologia.

No capítulo sete, (Inter)subjetividade, aprendizagem organizacional e mudança: algumas ferramentas lúdico-pragmáticas, apresentamos as principais 
correntes da metáfora da organização que aprende, ferramentas e instrumentos de trabalho a serviço do desenvolvimento de uma liderança comunicativa e da mudança.

Em anexo, apresentamos o roteiro para análise estratégica do perfil assistencial das especialidades médicas, constituído pelas matrizes referentes às várias etapas do enfoque respectivo, os critérios de análise estratégica explicitados com as perguntas necessárias à avaliação dos mesmos, e toda a orientação para formular uma estratégia e um plano de ação.

Este é um trabalho coletivo. Não há produção a partir de zero. Os principais autores que trabalhamos estão presentes no livro e este se propõe a reunir suas várias subculturas dentro do universo cultural maior definido pelo alcance do título. A dinâmica da pós-graduação da Ensp e seus vários atores também está presente. Trazemos a contribuição de ex-alunos, notadamente o grupo da Saúde Mental do Curso de Gestão Hospitalar de 1997, co-autor do capítulo três, e dos alunos de várias turmas da disciplina de Planejamento e Gestão em Saúde do Mestrado de Saúde Pública da Ensp, que nos ajudaram a construir os cenários para o PSF.

Enfim, esperamos sinceramente que este livro seja útil para o leitor e contribua para o ensino da gestão em saúde e para a gerência organizacional. 


\section{Planejamento e gestão em saúde: flexibilidade metodológica e agir comunicativo}

Francisco Javier Uribe Rivera

Elizabeth Artmann

Neste capítulo inicial, visamos a realizar uma análise das perspectivas teórico-metodológicas do planejamento/gestão em saúde no Brasil. Para tal, nos vemos obrigados a assumir uma perspectiva situacional e a resgatar do conjunto de nossas reflexões e leituras um fio condutor, o das possibilidades do planejamento estratégico, segundo a nossa matriz cultural, na constituição de organizações solidárias. O termo comunicante atribuído a essas organizações é retirado de Bartolli (1992) apud Rivera (1996a) e corresponde a organizações abertas, evolutivas, flexíveis, com finalidade explícita e responsabilizante para todos.

No desenvolvimento deste excurso, identificamos os aspectos produtivos da proposta do planejamento estratégico situacional e suas lacunas conceituais e metodológicas, procurando indicar possíveis áreas de complementação que poderiam ser motivo de investigação e de aplicação, no intuito de abrir caminho a uma proposta mais ampla e comunicacional do objeto aludido. Desta maneira, tentamos dar um substrato mais prático à alternativa do planejamento comunicativo resgatada de uma crítica ao modelo puramente estratégico (Artmann, 1993; Rivera, 1995).

No percurso do trabalho, procuramos também fazer um mapeamento de tendências na área de planejamento e gestão nos planos nacional e internacional. Não há a intenção de fazer uma análise aprofundada destas, mas de fazer alguns comentários que podem levar a questionamentos delimitadores de objetos de pesquisa.

Deve ficar claro ao longo do trabalho que situamos o planejamento - como momento de desenho - no interior do processo de gerenciamento/gestão de serviços e sistemas. O planejamento, assim, é entendido como ferramenta organizacional, fazendo parte de um processo mais amplo de desenvolvimento das organizações, que valoriza a condução da ação. As próprias possibilidades do planejamento são interpretadas aqui como mediadas/subordinadas à cultura das organizações. 


\section{O Planejamento Situacional como Possibilidade Instituinte de uma Organização Comunicante}

O planejamento fracassa na sua tentativa original de obtenção de uma regulação global, imperativa, da sociedade. Como alternativa à economia de mercado, o planejamento realizado pelos países socialistas não deixou de ser o modelo de regulação de um ator único, de um ator tecnocrático, que subordinou as relações intersubjetivas a uma visão de desenvolvimento com base no determinismo econômico.

Os modelos de planejamento global de que o setor saúde se apropria, como o Cendes/OPS, padecem do mesmo problema: a incapacidade de totalização a partir de uma perspectiva central de atores e instituições díspares, com racionalidades distintas. Há uma incapacidade do Estado de representar a diversidade mediante atos formuladores que substituem a negociação política.

O planejamento estratégico em saúde surge, em meados da década de 70, como a tentativa reconhecer a complexidade ao introduzir as idéias da superioridade do político sobre o econômico e da diversidade de atores-sujeitos do ato de planejar. A questão da viabilidade política passa a ocupar um papel central e a definição de propostas/compromissos de ação, a depender de uma articulação que se abre a uma perspectiva policêntrica de análise.

Talvez o grande mérito do planejamento estratégico tenha sido trazer à tona a necessidade de diálogo. Falar em planejamento comunicativo corresponde a uma interpretação do planejamento estratégico matusiano como a possibilidade de uma problematização coletiva, capaz de articular sujeitos sociais, como a possibilidade de incorporação de um raciocínio sobre a governabilidade de situações de compartilhamento e dispersão do poder que enfatiza a negociação política.

Ainda que o planejamento estratégico não tenha colocado com transparência essa perspectiva - sua abordagem do poder como relação entre acúmulos de recursos mobilizados em torno do objetivo da vitória de atores individuais oculta essa visão -, encontramos aspectos que permitem uma interpretação comunicativa. O reconhecimento do ato de planejar como relação interativa, a adoção da negociação cooperativa como meio estratégico possível, a valorização da explicação do outro como parâmetro de crítica da nossa e possível complemento e, finalmente, o destaque concedido à cultura no delineamento das regras institucionais são elementos que abrem caminho para uma interpretação menos presa a uma racionalidade pura de fins.

Assume-se o planejamento comunicativo como meio de construção de organizações dialógicas. Um aspecto fundamental deste enfoque é a busca da inte- 
gração, da possibilidade de um projeto solidário, entendido como desafio gerencial permanente. Nesta perspectiva, a escolha dos métodos de desenho ou de análise se subordina a esse objetivo próprio ao campo da gestão. Podem-se utilizar vários métodos que criem a possibilidade de fluxos de comunicação ampliada e de negociação de compromissos. Não há, portanto, a pretensão de uma exclusividade metodológica. O próprio método deve passar por um confronto com a diversidade.

Vale ressaltar que a perspectiva comunicativa não se reduz à escolha de métodos, mas envolve o processo gerencial como um todo, a partir de uma racionalidade ampliada, para além da racionalidade de fins, considerando o mundo da vida dos atores envolvidos em uma postura dialógica que motive a construção de projetos que possam ser assumidos coletivamente como compromissos.

Ajudar a desenvolver uma dinâmica de direção que potencialize o diálogo gerador de compromissos é, então, o fio condutor de uma nova compreensão do planejamento que não consegue mais se divorciar da gestão. Matus (1994a) entendeu muito bem que a viabilidade do modelo racional de planejamento por ele defendido dependia de determinadas características das regras organizacionais, especialmente das regras de responsabilidade que sobredeterminariam a qualidade da gestão.

O triângulo de ferro do Planejamento Estratégico Situacional (PES) (Matus, 1994a) pode ajudar a delimitar os contornos de uma organização comunicante ou dialógica. Os três vértices representam os principais subsistemas do sistema de direção estratégica: a Agenda do Dirigente, que exige concentração no que é estratégico, a Gerência por Operações e o sistema de Petição e Prestação de Contas. $\mathrm{O}$ autor defende que a pouca responsabilidade gera uma tendência no sentido da centralização e da ingovernabilidade. A falta de prestação de contas leva o dirigente a não organizar a sua agenda de modo a priorizar problemas de alto valor relativo. Desta maneira, acumula todo tipo de problemas, não delega, gerando, como conseqüência, a ingovernabilidade (falta de poder e autonomia decisória).

Idealmente, defende-se o objetivo da construção de uma organização onde a prestação de contas por resultados seja uma norma interiorizada culturalmente pelos indivíduos, onde haja desconcentração do poder e delegação permanente (uma sábia distribuição do poder de processamento de problemas) e onde predomine um tipo de gestão criativa por operações ou por objetivos.

Para o autor, a responsabilidade supõe uma demanda de planejamento criativo e este último supõe um estímulo à descentralização. É importante destacar que Matus, junto com Trosa (2001), entende a responsabilidade ligada à possibilidade de controle dos processos de produção técnica e organizativa por parte de quem se coloca como objeto de controle. Estes dois autores desmistificam uma deter- 
minada crítica radical à gestão por objetivos, de negação do planejamento, ao afirmar que, sem objetivos livremente planejados em ambientes comunicativos, não é possível desenvolver a responsabilidade individual. Pode-se dimensionar sua importância nos marcos dos processos de reforma do setor público, como uma postulação do princípio de que a responsabilidade, embora pressuponha a descentralização, a responsabilidade opera como um freio a uma descentralização exagerada, sem controles, geradora de desigualdades e de mais fragmentação. Isto se aplica à crítica feita ao processo de descentralização do Sistema Único de Saúde (SUS) do Brasil, de municipalização autárquica, típica dos anos 90, pela proposta da Noas (Brasil, 2002), em que se reivindica mais eqüidade e integralidade. A este respeito, vale a pena lembrar, ainda, a ênfase dada por Matus (1994 a, b) à combinação inteligente entre centralização e descentralização.

Matus acredita que, com novas práticas gerenciais, será possível viabilizar uma alta qualidade da gestão. Estas novas práticas gerenciais se confundem com a proposta de seu sistema de direção estratégica, que, além de contar com os subsistemas destacados, deve ser apoiada por outros, como o planejamento estratégico, o sistema de informações etc. A recomendação explícita é de que essa construção siga o modelo de uma reforma organizativa vertical, no sentido de uma reforma radical e seletiva em todos os sistemas relevantes da organização simultaneamente, dada a mútua dependência de todos os subsistemas, cada um gerando demandas para os outros.

A sobredeterminação que as regras de responsabilidade exerceriam sobre toda a dinâmica de gestão reforça a importância da cultura como conjunto de estruturas mentais que subordinariam todas as práticas de trabalho e as derivadas formas organizativas. A necessidade de impactar esse baluarte definidor das virtualidades gerenciais chama a atenção para a prioridade dos componentes Teoria e Treinamento em quaisquer processos de mudança organizacional. Assim, o primeiro passo de uma estratégia de reforma administrativa estaria representado no modelo matusiano pelo desenvolvimento de um centro de treinamento que procuraria promover novas práticas gerenciais e de trabalho.

Sutilmente, o voluntarismo racionalista de Matus encontra um limite nas possibilidades de lidar com cultura. Embora reconheça a primazia da cultura em relação aos processos de trabalho, o autor não aprofunda sua análise em busca de uma proposta de intervenção mais eficaz. A cultura impõe um elemento de moderação que dificulta o estabelecimento de prazos para a mudança organizacional, alimentada pela indeterminação do processo de mudança cultural (Rivera, 1996a; 1998a; Artmann, 1997a).

Não questionamos a proposta de treinamento e teoria em si, mas devemos relativizar seu impacto quando vista como medida isolada de atuação sobre es- 
truturas mentais. Para atingir esse objetivo, o desenvolvimento de práticas educativas permanentes deveria ser acompanhado de mudanças no sistema de gerência. O próprio Matus assinala que a mudança das práticas de trabalho subordinadas às estruturas mentais - depende da introdução de novos métodos e sistemas devidamente fundamentados em treinamento. Embora admita uma relação quase linear da cultura para as práticas de trabalho e destas para as formas organizativas, o autor assinala a existência de relações inversas, mais fracas a curto prazo, mas passíveis de tornarem-se muito fortes em um período maior (Matus, 1997). Nesta perspectiva, a introdução de novas racionalidades gerenciais pode gerar impactos para a cultura em longos períodos. Basicamente, pensamos na introdução de um sistema de gestão criativa que priorize formas de tomada de decisão e de controle coletivas, consensuadas, capazes de estimular a comunicação. A única possibilidade de mudar cultura a longo prazo reside na capacidade de construção legitimada de novas representações que os atores podem ter em função de sua participação em processos comunicativos, de aprendizagem. De qualquer maneira, a cultura terá de ser considerada como elemento de viabilidade ou de modulação da proposta de mudança organizacional. Nas organizações do tipo profissional, segundo classificação de Mintzberg (1989), como é o caso das organizações de saúde, não se justifica a introdução de um sistema pesado de gestão estratégica, do tipo supraestrutural, mas sim de um conjunto de práticas que, de maneira mais informal, contenham filosofia da intensificação do espírito da gestão por compromissos. O dado cultural da forte autonomia profissional nessas organizações sugere reforçar o objetivo de ajudar os profissionais a internalizar o raciocínio estratégico como parte de seu processo de decisão cotidiano, como alternativa a pesados processos de formalização de planos realizados em instâncias separadas dos centros operadores, de corte tecnoburocrático.

Em relação a esta questão, temos destacado a necessidade de valorização da reflexão realizada por autores da área da saúde pública (Dussault, 1992; Lima, 1994) acerca dos requisitos em termos de modelo de gestão colocados pela leitura das características das organizações profissionais de saúde. A complexidade do trabalho nessas organizações, a impossibilidade relativa de uma padronização mecanística e a intensa distribuição do poder sugerem, junto com outras características, um modelo de gestão negociado, de ajustamento mútuo, comunicativo. Isto reforça nossa perspectiva de organização comunicante.

Nesta perspectiva da organização comunicante, o desenvolvimento de novas racionalidades gerenciais como desafio cultural vai supor o exercício de uma liderança para a aprendizagem, e de complexos processos de estabelecimento de redes interativas de natureza dialógica e instrumental. 
De Matus (1993), resgatamos, principalmente, os seguintes elementos: a idéia de um sistema de gestão descentralizada por operações; a análise de problemas e de soluções, bem como aspectos da análise de viabilidade e do desenho estratégico.

É inerente a um sistema de gestão descentralizada definir objetivos a partir de problemas colocados fora e dentro da organização (ou macroorganização). A capacidade de processamento destes, entendidos como necessidades declaradas ou demandas, define a qualidade da oferta institucional. A arte de gerir consiste, para Matus (1994a), em saber distribuir bem os problemas pela organização, de modo que todos os níveis estejam sempre lidando de forma criativa com problemas de alto valor relativo. $\mathrm{O}$ modelo organizacional proposto por este autor é o de uma organização reflexiva a todos os níveis, como condição de governabilidade.

O caráter totalizador e rigoroso da explicação situacional facilita a escolha de operações de caráter transversal ou horizontal, que transcendem setores, departamentos e unidades e, nesta medida, o planejamento situacional favorece a integração horizontal, sob a forma de uma estrutura matricial por projetos. A horizontalização pode ser entendida aqui como sinônimo de descentralização e de criatividade, de tratamento multidisciplinar.

Há, no PES, um apelo claro no sentido da coordenação lateral, como alternativa a um tipo de estrutura tipicamente hierárquica. Este elemento característico de estruturas descentralizadas e participativas tem sido destacado pelo Laboratório de Planejamento do Departamento de Saúde Coletiva (Lapa), da Unicamp, como parte de um modelo que enfatiza, também, uma boa dose de autonomia das unidades de produção e a necessidade de colegiados de gestão que democratizem a tomada de decisão. Por referência às organizações profissionais de saúde, defendemos a tese de equipes de gestão com representantes das principais categorias profissionais.

A complexidade do PES tem sido suavizada através de propostas e adaptações do método (Artmann, 1993; Cecílio, 1997) que conservam aspectos como a necessidade de uma boa descrição do problema como base para uma explicação eficaz; a diagramação das relações de causalidade sob a forma de uma rede ou árvore simples de causalidade; a definição de nós críticos com base no protocolo ad-hoc do PES e a descrição dos mesmos tendo em vista ajudar à definição do conteúdo mais preciso das propostas de intervenção (operações), vistas como macrounidades de ação que incidem sobre os nós críticos; a definição por operação da relação recursos/produtos/resultados; uma análise de viabilidade simplificada baseada na motivação dos atores em relação às operações e na definição de quem controla predominantemente os recursos envolvidos nas operações; e, finalmente, a necessidade de relacionar genericamente estratégias de viabilização e construir indicadores de acompanhamento do plano. 
A adaptação e simplificação do PES tem ajudado a evitar uma centralização obsessiva em questões metodológicas, reforçando a idéia de que o método é um simples meio a serviço de sujeitos.

Alguns problemas ou deficiências do PES já foram apontadas por nós em alguns trabalhos. O primeiro é a inexistência de uma reflexão mais aprofundada sobre cultura como componente da viabilidade de uma intervenção planejada (Artmann, 1993; 1997a; Rivera, 1995; 1996a). A necessidade de um desenvolvimento específico da tecnologia de negociação cooperativa é o segundo (Rivera, 1998b).

Uma determinada visão da liderança que destaca a necessidade de um estado maior constituído pelo desenvolvimento de superestruturas de gestão, em detrimento do aperfeiçoamento de habilidades da liderança centradas na capacidade da mediação das relações interpessoais (Rivera, 1996a; 1998a), representa outra deficiência do PES. Este questionamento deve ser suavizado tendo em vista a admissão, nos últimos trabalhos de Matus (1996), da possibilidade do exercício de uma liderança baseada na força moral e no consenso, identificada com o estilo Ghandi de fazer política (pouco expressivo historicamente).

A questão da validade do método para o delineamento ou precisão de uma visão compartilhada sobre a missão institucional (Artmann et al., 1997) também pode ser considerada um problema.

Outro ponto importante de debilidade é uma construção ainda muito simplificada da prospectiva, em que predomina uma relação excessivamente determinista do contexto sobre o plano e onde as relações cruzadas entre as variáveis-chave do cenário não são devidamente registradas ou formalizadas (Rivera, 1998c).

A possibilidade de construção de um projeto coletivo a partir da multiplicidade de racionalidades presentes em organizações de saúde representa outro problema, assim como as dificuldades inerentes à própria complexidade do método.

Estas áreas definem desafios metodológicos importantes.

A questão da cultura nos leva a Thévenet (1986; 1993), autor francês que destaca a necessidade de uma análise participativa da cultura que colabore para discernir nela aspectos fortes que podem ser funcionais à mudança. A visão da cultura como recurso se coloca pragmaticamente a serviço do objetivo de discernir os aspectos que deveriam ser reforçados para enfrentar problemas correlatos. A relação problemas-cultura, como definição desafiadora permanente, apresenta a cultura como condição de viabilidade das formas de enfrentamento dos problemas. 
O autor propõe uma grade de análise cultural, com categorias de informação marcantes e formas de estabelecimento de hipóteses culturais. O caráter participativo e sistemático da pesquisa cultural colabora para a possibilidade de realização de um sentido profundo inerente a essa análise, o de ajudar a desvendar representações sociais compartilhadas, o qual reforça núcleos de colaboração e agregação institucionais. A cultura, como um conjunto de tradições e préinterpretações de situações, tem um papel determinante na organização e sua abordagem é bastante interessante para a compreensão do mundo organizacional. Contudo, com base em Habermas (1987), entendemos que as tradições culturais, ainda que condicionem fortemente o funcionamento das organizações e a ação dos atores, podem ser questionadas a partir do exercício de um discurso crítico. Esta questão encontra-se abordada no texto de Artmann (1997a).

O PES distingue, no momento estratégico, a negociação (conflitiva, mista e cooperativa) como um meio estratégico possível. A indicação da necessidade de um tal tipo de estratégia não é suficiente se não for acompanhada de uma reflexão mais aprofundada do conteúdo específico da negociação. A Escola de Negociação de Harvard, de Fischer e Ury (1985), enseja uma bom modelo de negociação cooperativa, do tipo ganhar-ganhar, que se aproxima de um modelo argumentativo. Aspectos marcantes deste enfoque são:

- a necessidade de separar a negociação da substância do problema do relacionamento intersubjetivo, que requer um investimento particular;

- a necessidade de negociar a partir dos interesses, dos pressupostos ou motivações das posições, e não das posições mesmas, procurando discernir, em posições aparentemente opostas, interesses comuns a explorar em termos de faixas de acordo, ou interesses distintos, porém não conflitantes, que podem ser harmonizados;

- a idéia de que a negociação é um processo ideativo, criativo, interdisciplinar, de geração de múltiplas opções de ganho mútuo, o qual desvirtua a idéia da negociação como um bolo fixo;

- a tese de que o fundamental é negociar critérios de validade universal ou de maior legitimação capazes de balizar objetivamente a possibilidade de um acordo.

O enfoque de negociação de Como Chegar ao Sim (1985) pode e deve ser explorado como complemento necessário ao planejamento estratégico e ao desenvolvimento das habilidades da liderança.

O paradigma da "organização que aprende” de Peter Senge dá uma especial atenção à questão da liderança. Em “O Novo Trabalho do Líder”' (Starkey, 1997), o autor se contrapõe à visão da liderança forte, carismática, assumindo a liderança como a principal responsável pelos processos de aprendizagem coletiva. Apren- 
der significa incorporar habilidades novas, nunca completamente realizadas, de interação e de reflexão. Estas habilidades básicas, que supõem um questionamento profundo dos modelos mentais, dos pressupostos e crenças dos participantes organizacionais, podem ajudar a consolidar uma visão compartilhada capaz de tensionar a organização em um sentido renovador e produtivo. Não haveria, para Senge, algo como conteúdos universais e específicos da administração, mas o desafio de criar uma liderança disseminada, como possibilidade de mediação reflexiva das relações interpessoais e de escuta da subjetividade (expressa por meio do não dito que mediatiza negativamente relações de aprendizagem mal sucedidas). Parte importante da proposta deste autor refere-se à necessidade de desenvolver um raciocínio estrutural no que diz respeito à explicação de problemas, buscando-se causas essenciais de alto poder de alavancagem, o qual o aproxima de Matus. Outra contribuição refere-se à necessidade de trabalhar a técnica de simulação de cenários como instrumento de aprendizagem. Sobre este este último particular, Senge sustenta que a aprendizagem da experiência é limitada, pois a realidade é complexa, sendo difícil o estabelecimento de relações claras de causa-efeito entre as decisões que tomamos hoje e suas conseqüências, dados seus distanciamentos eventuais no tempo e no espaço. Este elemento de indeterminação obrigaria a tentar aprender do futuro, mediante experiências de simulação que essencialmente ajudariam a 'costurar' uma visão de futuro organizacional. Para o autor, o grande mérito da prospectiva é possibilitar um diálogo sobre os modelos mentais que embasam as visões de futuro, que cria possibilidades harmonizadoras no que está relacionado à visão organizacional. Trazer "a lembrança do futuro" corresponde à tentativa de reforçar uma construção positiva da visão que opere como um pólo forte da modelagem do projeto institucional, que se tensiona criativamente com a experiência dos problemas da organização. Há, em Senge - que utilizou como base a experiência de seguidores da learning organization -, uma nova compreensão do planejamento como processo de aprendizagem. O fundamental não seria a elaboração de grandes planos estratégicos, mas a difusão ou incorporação de um raciocínio estratégico pelo corpo organizacional, a ser aplicado no cotidiano das decisões sobre opções alternativas. Coerente com o pensamento de Mintzberg, a estratégia seria o resultado, não de um processo superior destacado no tempo e no espaço, mas de múltiplas interações entre os agentes organizacionais munidos de habilidades comuns como, por exemplo, de análise de sistemas. Este conceito seria o de estratégia emergente, que desde a nossa perspectiva, valoriza o planejamento tático-operacional ou o momento tático-operacional do planejamento.

Um dos nossos questionamentos diz respeito à contribuição do PES para o delineamento da missão, dos produtos organizacionais. Matus (1994b) afirma que o primeiro desafio da organização é a correta delimitação de seus produtos e responsáveis. O planejamento a partir de problemas terminais, colocados 
pela ambiência externa, pelos usuários da organização, poderia ajudar a realizar este delineamento. Vários passos seriam necessários: um levantamento exaustivo dos problemas de saúde de uma área de referência; sua priorização em função de critérios sociopolíticos e técnico-sanitários (epidemiológicos, econômicos, de vulnerabilidade etc.); uma explicação adaptada procurando selecionar nós críticos nas várias áreas de prestação de serviços possíveis, setorial e extra-setorialmente (promoção, prevenção específica, tratamento, acompanhamento, reabilitação, etc.) e, finalmente, uma distribuição das operações-ações entre as várias unidades de serviços de saúde da área (em função do grau de complexidade acordado para as mesmas) e as unidades extrasetoriais. Devem-se respeitar algumas particularidades do setor: critérios específicos de priorização; classificação das operações/ações em várias formas específicas de cuidado/prestação; um planejamento ex-ante da complexidade das unidades operacionais. A priorização de determinados problemas não pode deixar de ser acompanhada por um tratamento extensivo aos problemas menos prioritários, ainda que em um nível de manutenção que implique a não piora da situação de saúde. A necessidade de um atendimento universal em saúde leva a considerar o aspecto de rede e aspectos extrasetoriais dos problemas de saúde.

A maior parte das experiências que temos acompanhado reflete uma tendência a trabalhar no âmbito dos problemas mais intermediários que afligem uma organização, em detrimento da seleção de problemas terminais no nível de rede local, embora aqueles impactem também os produtos finais. Neste caso, a seleção de problemas pressuporia uma missão previamente definida, o qual reforça a importância de pré-requisito da mesma. Às vezes, a própria falta de clareza sobre a missão aparece como problema (Artmann et al., 1997b). Acreditamos, porém, que há no Brasil um capital acumulado no âmbito da definição da oferta a partir de problemas terminais dentro da corrente da Vigilância à Saúde, que tem produzido instrumentos próprios de programação situacional. Esta abordagem não é denominada programação situacional impunemente: é bastante extensiva e se apóia em formas de territorialização, em formas de estimativa rápida de problemas que esquadrinham minuciosamente regiões, em mapas de risco epidemiológico e social, e finalmente, na dinâmica de explicação de problemas e de desenho de ações.

Esta é, sem dúvida, uma das áreas de pesquisa avaliativa mais importantes do momento. Pensamos, porém, que a situação é tão ou mais complexa no âmbito do setor hospitalar envolvendo também o subsetor privado. Este âmbito está caracterizado, em alguns espaços, por situações de concorrência ou de descoordenação (desintegração, duplicidade), em que se disputam clientela ou recursos. Aqui nos parece útil o enfoque de gestão estratégica hospitalar de Michel Crémadez: a démarche stratégique (1997). 
Esse enfoque supõe inicialmente a segmentação ou agrupamento de atividades homogêneas por especialidade. Em seguida, realiza-se a análise estratégica específica de cada segmento em função de duas dimensões: o valor de cada segmento, correspondente à capacidade de atração de clientela e ao interesse do hospital de lhe alocar recursos, e a posição competitiva do mesmo função do grau de controle dos fatores chave de sucesso respectivos. Calculam-se o valor e a posição concorrencial por meio de um sistema de notação. A partir desta análise, se constrói o porta-fólio de cada especialidade, que corresponde à localização de todos os segmentos dentro de uma grade constituída pelas duas variáveis ou dimensões anteriores. Este documento serve de base para a definição da estratégia, consistente de três grandes objetivos: segmentos a expandir; segmentos a manter; segmentos a desativar, recortar, negociar com a rede. Finalmente, desenha-se o plano de ação, caracterizado, geralmente, por atacar os pontos fracos da análise concorrencial e mexer com aspectos do valor, quando possível.

Este enfoque tem sido aplicado a algumas situações hospitalares e, embora não tenhamos tido tempo de avaliar com mais profundidade estas experiências, ainda recentes, detectamos um relativo sucesso no delineamento da missão. Apesar da linguagem típica do planejamento estratégico corporativo, este instrumento ajuda a negociar formas de integração com a rede. Fundamentada na estratégia de diferenciação ou de aprofundamento das competências distintivas, a análise estratégica de Crémadez permite transformar a concorrência frontal em colaboração. É, finalmente, um espaço de comunicação que fortalece a autonomia dos centros operadores e que ajuda a promover mudanças culturais pela difusão do pensamento estratégico nestes centros.

Um confronto PES/ démarche acerca das possibilidades da utilização de ambos no caso da formulação da missão é um tema de investigação que estimulamos. Parece-nos que os dois enfoques podem contribuir muito mais do que a Qualidade Total, que, para além de seus apelos no sentido das Jornadas de Missão, não exibiria enfoques metodológicos tão estruturados.

A questão da prospectiva tem sido embrionariamente desenvolvida por nós à luz de Godet (Rivera, 1998c), com a intenção de solucionar problemas não resolvidos pelo PES. Do enfoque de Godet, duas técnicas nos chamam a atenção: a análise estrutural, que é uma simulação do poder de influência recíproco (duas a duas) das variáveis inicialmente relacionadas para construir o cenário do sistema escolhido, e a matriz dos impactos cruzados centrada nas principais tendências ou hipóteses de comportamento das variáveis. A primeira permite reduzir o número de variáveis, ao selecionar as mais importantes (de maior poder de determinação), e a segunda possibilita analisar em que medida uma hipótese de comportamento de uma variável influencia as hipóteses de comporta- 
mento das outras. Podemos dizer que estes dois instrumentos são de grande valia na construção de cenários.

Alicerçada na consulta a especialistas para reduzir a subjetividade, na análise do jogo dos atores e em um software baseado em cálculo de probabilidades de cenários, a abordagem de Godet corresponde ao que se tem de mais avançado no campo da prospectiva mais formalizada.

Não se pode esquecer, porém, que pode-se traduzir a mesma abordagem formalizada em um enfoque mais qualitativo e simples, que resgata as duas técnicas mencionadas. A simplificação da técnica, posta a serviço da discussão dos modelos mentais dos participantes da simulação, nos moldes da proposta de Senge, parece pertinente.

\section{Panorama dos Enfoques Gerenciais no Mundo}

Da multiplicidade de enfoques existentes, comentaremos, de maneira sintética, quatro correntes que nos parecem expressivas: A Gestão da Qualidade Total (QT), a Reengenharia, o Planejamento Estratégico Corporativo e a Learning Organization.

Sobre a QT tecemos comentários em artigo ad-hoc (Rivera, 1996b). Com um discurso estimulante de centralização no cliente e de reconhecimento das relações de confiança fornecedor-cliente como garantia de qualidade, a QT parece não ter estruturado instrumentos e técnicas que lhe propiciem a superioridade metodológica sobre outras correntes, principalmente sobre a variedade de enfoques estratégicos. Apesar de contar com instrumentos de utilidade para a detecção e explicação de problemas (em ambientes participativos), a QT não desenvolveu enfoques próprios de análise de atores e de prospectiva. Isto, somado a toda uma tradição histórica de preocupação estatística com a redução de variedade e com a padronização produtiva, tende a fazer dela uma corrente normativa com matizes humanitárias. Recentemente, evoluiu, a partir de uma leitura menos racionalizadora da obra de Deming, para um discurso que sustenta a alternativa de uma Liderança Comunicativa em contraposição à Administração por Objetivos e para a incorporação de elementos da Administração Estratégica, principalmente o conceito de fatores chave de sucesso. Sem um corpo teórico-metodológico próprio e adaptado aos avanços da época, a QT persiste como um remanescente que se alimenta de todos e pretende ser o grande abrigo de todos eles.

A Reengenharia, vista equivocadamente por adeptos da QT como sua continuação, entra no mercado como uma moda de poucas receitas, algumas extre- 
mamente válidas, porém de efeitos secundários imprevisíveis. A compactação de processos é uma delas. A crítica à fragmentação exagerada do trabalho e a defesa da criação de equipes de trabalho são fatores que colaboram para uma maior criatividade e diversificação, para uma maior inovação. Menos padronizadora do que a QT, a Reengenharia sucumbe pelo peso do autoritarismo, pela pretensão de provocar rupturas organizacionais, pelos motivos ocultos de enxugamento e de demissão de força de trabalho, secundários à tentativa de integração de tarefas e de simplificação dos múltiplos controles anteriores. No campo do planejamento, uma leitura produtiva da Reengenharia, aliada ao enfoque lingüístico das organizações de Flores (1989), pode ser verificada em Matus (1994b) e traz algumas contribuições importantes.

O Planejamento Corporativo Americano, representado, por exemplo, por Michael Porter (1980; 1986), da Escola de Negócios de Harvard, mostra um grande dinamismo no âmbito das grandes corporações americanas e japonesas. Apoiado na segmentação estratégica das empresas e em um tipo de análise estratégica das possibilidades mercadológicas desses segmentos, este enfoque tem-se mostrado útil para a definição de estratégias que permitam vantagens comparativas. Esta corrente lança mão de vários porta-fólios de atividades, um dos quais é o portafólio mercado/posição concorrencial, adaptado criativamente por Crémadez para uma aplicação em hospitais e no setor público. Ainda restam dúvidas quanto à aplicação do modelo empresarial original à lógica do setor social.

Já se comentaram aspectos da Learning Organization em relação à liderança. Aprendido na V Disciplina de Senge (1998), o paradigma da organização que aprende constitui-se de técnicas e instrumentos que visam a despertar habilidades de aprendizagem. A questão seria aprender a aprender, através da incorporação de habilidades de reflexão, de indagação, de argumentação, de colocação autêntica. Estas capacidades dizem respeito a cinco disciplinas: a aprendizagem em equipe; $\mathrm{o}$ trabalho com modelos mentais; o domínio de si mesmo; a visão compartilhada; o pensamento sistêmico. Um aspecto crítico desta corrente corresponderia ao uso proposto por Senge da idéia de arquétipos sistêmicos ou de regularidades de comportamento para efeitos de aprendizagem. Com esta tentativa, Senge reduz os comportamentos globais possíveis das empresas econômicas a uns poucos modelos cuja capacidade de dar conta da diversidade pode ser questionável.

\section{O Planejamento de Saúde no Brasil}

Mehry (1995) fez uma boa classificação do estado da arte em artigo conhecido. Do nosso ponto de vista, os quatro modelos referidos podem perfeita- 
mente conviver em um fluxo de muita alimentação. De sua diversidade situacional de pontos de vista, podem-se apreender aspectos que podem tornar-se complementares, ainda que as divergências apontem, por vezes, para a construção de diferentes tipos de modelos assistenciais.

A corrente da Vigilância à Saúde destaca-se pela busca de operacionalização prática de conceitos do planejamento situacional dentro do contexto da construção da idéia de distrito sanitário como processo social de mudança da práticas sanitárias, no sentido da eficiência e eficácia sociais, eqüidade e democratização. Este processo manifesta-se no espaço local, onde se estabelecem as relações entre instituições de saúde, de preferência ancoradas no paradigma da promoção da saúde, sob a regulação de uma autoridade sanitária local e a sociedade ou grupos sociais, com a diversidade de problemas que se expressam na singularidade daquele território. Este, além de território-solo, constitui-se em território econômico, político, ideológico, cultural e epidemiológico.

Este enfoque reúne um conjunto de técnicas de vários campos, do planejamento urbano-espacial, da epidemiologia, do planejamento estratégico em saúde e da gestão. Nutre um conceito alternativo à velha saúde pública que se destaca pela tentativa de criar horizontalidades entre os velhos programas sanitários, através do planejamento a partir de problemas, baseado na concepção matusiana, em contraposição ao enfoque por programas.

Facilitador de uma visão mais socioambiental do binômio saúde-doença, este enfoque abriria caminho para uma perspectiva de intersetorialidade e de promoção em saúde, contribuindo, assim, para uma recriação dos modelos assistenciais, a partir de novas práticas sanitárias. Estas práticas sanitárias se constituem em conjuntos de processos de trabalho, articulados em operações, que impõem uma estratégia de ação sobre os nós críticos dos problemas e seus efeitos em um dado território.

Duas práticas sanitárias contraditórias coexistem no Distrito Sanitário. A primeira refere-se à Vigilância à Saúde, direcionada para problemas de enfrentamento contínuo, escolhidos pelo alto impacto nas condições de vida dos grupos populacionais das microáreas. A segunda, a Atenção à Demanda, volta-se para a intervenção pontual, ocasional sobre os efeitos dos problemas ao nível individual autopercebidos e é considerada estratégica para a legitimidade social do projeto e para a captação de informações para a Vigilância à Saúde que, pretende-se, venha a ser a prática hegemônica.

Um problema deste enfoque poderia estar representado pela ausência de uma proposta que dê conta das particularidades do âmbito hospitalar.

A corrente da Programação em Saúde da Universidade de São Paulo (USP) propõe a construção de um sistema de saúde programado em termos de suas 
atividades a partir da Epidemiologia Social. Visa a reduzir uma lógica de atenção espontânea, de mercado. Afirma-se em um tipo de construção micropolítica de novas práticas assistenciais, de referenciamento a equipes de saúde integral (em vários campos do atendimento). Busca promover novas aglutinações dos programas tradicionais em conjuntos mais amplos e modernos, privilegiando o componente populacional. Os autores identificam uma evolução da programação de uma posição de "técnica de planejamento" (racionalização econômica do processo de produção em saúde) para um significado de "modelo assistencial ou modelo operatório das práticas de saúde" (tecnologia de trabalho), integrando as práticas médica e sanitária, apresentando-as como um campo de experimentação de novas formas de trabalho em saúde. Problemático pode ser para esta corrente o grau de subordinação da velha clínica a uma racionalidade programada. Talvez seja menos voluntarioso pensar em termos de uma tensão permanente entre demanda programada e espontânea, no contexto da qual procurar-se-ia uma hegemonia relativa da primeira, nos termos da Vigilância à Saúde. Destacase, ainda, a externalidade das questões de viabilidade com relação ao método. É pertinente, finalmente, destacar a evolução desta corrente de uma visão de ufanismo em relação às possibilidades da Epidemiologia como Sujeito do Planejamento (parafraseando o discurso crítico produzido no Lapa), para compreensão habermasiana de que o planejamento integrado do modelo assistencial do SUS é uma questão de negociação política, de comunicação, condicionando a resolutividade geral do sistema.

Em relação à corrente da Gestão Estratégica e do Planejamento de Saúde articulada ao Modelo Tecno-assistencial em Defesa da Vida, do Lapa, já comentamos os esforços desenvolvidos na direção do desenvolvimento de uma tecnologia leve de planejamento (a partir do enfoque matusiano e do ZOPP (sigla em alemão para o Método de Planejamento de Projetos Orientados por Objetivos). A noção de caixa de ferramentas (composição de técnicas, procedimentos e enfoques adaptados do PES, de Mário Testa, de elementos teóricos da psicanálise e da análise institucional, entre outros) dá uma idéia da flexibilidade de abordagem e da diversidade de instrumentos manipulados por esta corrente, que experimentou em profundidade tanto o planejamento situacional quanto o enfoque de qualidade total. Sua riqueza se explica pela acumulação de experiências (de condução e de consultoria/pesquisa) tanto na rede básica quanto no campo hospitalar, ainda que parta inicialmente de uma concepção redebasicocêntrica, propondo, depois, uma mudança da clássica pirâmide para um círculo, onde o sistema admitiria várias portas de entrada, segundo a melhor tecnologia e oportunidade para cada usuário. Os profissionais do Lapa sempre defenderam a flexibilização dos critérios de hierarquização. O território é visto com restrições: é importante definir a área de responsabilidade das instituições de saúde, mas o usuário não pode ser aprisionado em uma área restrita, pois se movimenta no 
sistema em busca da satisfação de suas necessidades. A concepção tradicional e verticalizada de programas é substituída pela formulação criativa de equipes locais, organizadas buscando evitar corporativismos e monitoradas por avaliações de desempenho referenciadas por metas vinculadas aos objetivos definidos para os serviços. A proposta de organização do sistema de saúde visa a dar conta das relações entre os diversos tipos de produtores, tendo nos gerentes locais/regionais uma base fundamental de articulação, onde todos os produtores deveriam estar submetidos ao controle público. A relação da unidade de saúde com a população é estruturada com algumas noções emprestadas da área de Saúde Mental: vínculo e responsabilidade e acolhimento, procurando-se desenvolver uma relação personalizada e humanizada.

A crítica dos profissionais do Lapa de Campinas às propostas tecnocráticas e prescritivas em planejamento e gestão que pressupõem uma precedência dos métodos em relação aos sujeitos é por nós partilhada. Segundo Matus, o método serve, no máximo, para ajudar a sistematizar o conhecimento da realidade e não substituí-lo. Quem planeja é sempre o ator. Para Matus, um ator com conhecimento do problema e capacidade de raciocínio estratégico com certeza enfrentará melhor um problema do que alguém com pouco conhecimento da realidade e apenas conhecimento de método, por melhor que este seja. De qualquer modo, não há como negar a importância de métodos que ajudem a realizar a complexa tarefa de gerir situações que apresentam variáveis não controláveis e que exigem respostas eficazes, criativas e flexíveis.

Partilhamos, ainda, da preocupação com o sujeito, e especificamente com a subjetividade, o que parece ser um diferencial analítico na proposta do Lapa. Embora ainda não se tenha um quadro claro de como a análise institucional recuperaria a subjetividade dos agentes em processos de autonomização e de instituição de novas relações de poder capazes de democratizar amplamente estruturas organizacionais, cumpre registrar, no entanto, o esforço desenvolvido para realizá-lo.

A abordagem comunicativa em planejamento, que tem origens a partir de reflexões teóricas sobre experiências com o enfoque do PES e do estabelecimento de um diálogo com a Teoria da Ação Comunicativa de Habermas, tem atualmente vários desdobramentos teórico-metodológicos e pragmáticos, alguns expostos na primeira parte deste texto. Alguns destes desdobramentos merecem ser aprofundados através de linhas de investigação, das quais ressaltamos:

- análise da cultura como componente de viabilidade de um projeto, buscando uma metodologia de escuta da cultura, o estabelecimento da relação cultura-problemas em face de uma determinado macroproblema e o desenho de estratégias de utilização da cultura como recurso da intervenção sobre problemas; 
- desenho metodológico e missão institucional, envolvendo uma análise comparativa das possibilidades do PES e do enfoque de Crémadez, em vários níveis de atenção em saúde;

- desenvolvimento de habilidades de liderança e de negociação, que configuram junto com o trabalho cultural o campo do que denominamos gestão pela escuta;

- $\quad$ discussão teórica geral sobre a relação entre a gestão pela escuta e os métodos racionalistas de gestão;

- aplicação mais sistemática da prospectiva como recurso crucial dentro do cálculo estratégico;

- possibilidades de diálogo entre o planejamento situacional e os enfoques da administração estratégica e do planejamento estratégico corporativo, favorecendo uma abordagem do contexto de mix público/privado;

- o resgate da subjetividade no campo da gestão, em processos de construção coletiva de projetos institucionais, a partir de conceito amplo de razão. É importante considerar a interrelação destas várias linhas e a preocupação com o desenvolvimento de métodos/enfoques, posturas e condutas que aprofundem processos de solidariedade e geração de compromissos compartilhados em um permanente aprender a aprender.

\section{Referências Bibliográficas}

ARTMANN, E. O Planejamento Estratégico Situacional: a trilogia matusiana e uma proposta para o nivel local de saúde (uma abordagem comunicativa), 1993. Rio de Janeiro: Escola Nacional de Saúde Pública. Dissertação (Mestrado).

ARTMANN, E. Cultura e Mudança Organizacional. São Paulo: Unicamp, 1997a. (Mimeo.)

ARTMANN, E.; AZEVEDO, C. S. \& SÁ, M. C. Possibilidades de aplicação do enfoque estratégico de planejamento no nível local de saúde : análise comparada de duas experiências. Cadernos de Saúde Pública, 13(4):723-740, 1997b.

BRASIL. Ministério da Saúde. Regionalização da Assistência à Saúde: aprofundando a descentralização com eqüidade no acesso. Norma Operacional da Assistência à Saúde NOAS-SUS 01/02 (Portaria MS/GM n³73, de 27/01/2002).Brasília -DF. 
CECÍLIO, L. C. O. Uma sistematização e discussão de tecnologia leve de planejamento estratégico aplicada ao setor governamental. In: MERHY, E. E. \& ONOCKO, R. (orgs.). Agir em Saúde.Um Desafio para o Público. São Paulo: Hucitec, 1997. p.161-167

CRÉMADEZ, M. Le Management Stratégique Hospitalier. Paris: InterEditions, 1997.

DUSSAULT, G. Gestão dos serviços de saúde. Características e exigências. $\mathrm{R} A P, 26: 8-19,1992$.

FISHER, R. \& URY, W. Como Chegar ao Sim. A Negociação de Acordos sem Concessões. Rio de Janeiro: Imago, 1985.

FLORES, F. Inventando la Empresa del Siglo XXI. Santiago do Chile: Hataché, 1989.

HABERMAS, J. Teoria da la Acción Comunicativa. Madri: Taurus, 1987.

LIMA, S. M. L. Definição e implementação de objetivos nas organizações públicas de saúde. RAP, 28:38-64, 1994.

MATUS, C. Política, Planejamento e Governo. Brasília: Ipea, 1993.

MATUS, C. Sobre la teoría de las macroorganizaciones. Revista PES n.3, Santafé de Bogotá. 1994a.

MATUS, C. El Metodo PES, reingenieria pública y la teoría de las conversaciones: trabas y problemas. Revista PES n.2, Santafé de Bogotá, 1994b.

MATUS, C. Chimpanzé, Maquiavel e Ghandi.Estratégias Politicas. São Paulo: Fundap, 1996.

MATUS, C. Adeus, Senhor Presidente. Governantes e Governados. São Paulo: Fundap, 1997.

MERHY, E. E. Planejamento como tecnologia de gestão: tendências e debates em planejamento em saúde no Brasil. In: GALLO, E. (org.) Razão e Planejamento. Reflexões sobre Política, Estratégia e Liberdade. São Paulo/Rio de Janeiro: Hucitec/Abrasco, 1995. p.117-194.

MINTZBERG, H. Mintz̧berg on Management: Inside our Strange World of Organizations. Nova York: The Free Press, 1989.

PORTER, M. Choix Stratégiques et Concurrence. Paris: Economica, 1980.

PORTER, M. L'Avantage Concurrentiel. Comment devancer ses concurrents et maintenir son avance. Paris: InterEditions, 1986. 
RIVERA, F. J. U. Agir Comunicativo e Planejamento Social (uma crítica ao enfoque estratégico). Rio de Janeiro: Editora Fiocruz, 1995.

PORTER, M. A gestão situacional (em saúde) e a organização comunicante. Cadernos de Saúde Pública, 12(3):357-372, 1996a.

PORTER, M. Planejamento estratégico-situacional ou controle de qualidade total? Um contraponto teórico-metodológico. Cadernos FUNDAP n.19, p. 25-45, 1996b.

PORTER, M. Cultura, Liderança Comunicativa e Gestão. Rio de Janeiro: Escola Nacional de Saúde Pública (Ensp/Fiocruz), 1998a. (Mimeo.)

PORTER, M. Comunicaşão e Negociação Gerencial (como Requisito das Organizações Profissionais de Saúde). Rio de Janeiro: Escola Nacional de Saúde Pública (Ensp/Fiocruz), 1998b. (Mimeo.)

PORTER, M. Análise Estratégica e Prospectiva. Rio de Janeiro: Escola Nacional de Saúde Pública (Ensp/Fiocruz), 1998c. (Mimeo.)

SENGE, P. A Quinta Disciplina. Arte e Prática da Organização que Aprende. São Paulo: BestSeller, 1998.

STARKEY, K. Como as Organizações Aprendem. São Paulo: Futura, 1997.

THÉVENET, M. La Culture d'Entreprise. Paris: Presses Universitaires de France, 1993.

THÉVENET, M. Audit de la Culture d'Entreprise. Paris: Les Editions d'Organisation, 1986.

TROSA, S. Gestão Pública por Resultados (quando o Estado se compromete). Brasília: ENAP/Revan, 2001. 


\section{Análise estratégica hospitalar e PROJETO ASSISTENCIAL: a perspectiva de Michel Crémadez e François Grateau}

Francisco Javier Uribe Rivera

A Démarche Stratégique representa, originalmente, o enfoque utilizado na definição da missão do Centro Hospitalar Regional Universitário (CHRU) de Lille, norte da França. Depois de uma visita a esta estrutura hospitalar, pude conhecer este importante instrumento de gerenciamento que, adaptado por nosso grupo ao Brasil, já foi aplicado em várias unidades hospitalares do Rio de Janeiro e divulgado pelo país. ${ }^{1}$

O termo démarche significa processo, trâmite, gestão, e poderíamos traduzilo como gestão estratégica. Nós nos propomos, neste capítulo, a apresentar, em grandes linhas, a proposta metodológica da Démarche Stratégique, bem como algumas de suas mais importantes referências teóricas.

A démarche é um método que supõe a adaptação de um enfoque empresarial ao setor público de serviços de saúde. Este enfoque de planejamento/gestão estratégica apóia-se em elementos da microeconomia, do campo da estratégia e da política, e da área do desenvolvimento organizacional e cultural. Introduz também algumas categorias próprias da área de saúde e da epidemiologia, reconhecendo a especificidade do setor público de saúde, na França. Está alicerçado em autores como H. Mintzberg (1982), Michel Crozier e Erhard Friedberg (1977), M. E. Porter (1982) e M. Thevenet (1986).

A partir de sua principal referência, a obra Le Management Stratégique Hospitalier, de M. Crémadez e François Grateau (1992; 1997), este enfoque propõe-se a

Destacam-se as experiências pioneiras no Hospital da Posse e no Hospital Phillipe Pinel e posteriormente nos hospitais da Lagoa, Cardoso Fontes, Raphael de Paula Souza e Lourenço Jorge, entre outras, mobilizando um grupo constituído pelo autor deste capítulo, por Elizabeth Artmann (Ensp/Fiocruz), Clayre Maria Bomfim Lopes (Nesc/UFRJ), Rejane Sobrino (Nesc/UFRJ) e Rosa Maria de Souza Souza (SES$\mathrm{RJ})$, entre outras. 
definir racionalmente a missão de um hospital, situando-o na perspectiva ideal de uma rede coordenada de serviços de saúde. Compreende-se, então, a organização hospitalar como uma organização pró-ativa, centrada sobre o exterior, que assume o ambiente como recurso e não como restrição. Isto significa que a definição da missão terá de ser negociada com o ambiente externo institucional, incluindo os outros hospitais da área à qual pertence. Desta maneira, destaca-se a capacidade pró-ativa da organização e sua atuação dinâmica sobre o ambiente.

As características das organizações sanitárias tendem naturalmente para um padrão que se distancia do ideal. Este ideal estaria representado pela aplicação de critérios de racionalidade econômica da missão, pela concepção do ambiente externo como recurso e por uma maior integração intrainstitucional. Contudo, o padrão apresentado pelas organizações de saúde e analisado com mais profundidade adiante tem alguns traços característicos: um processo de autonomização dos centros operacionais, decorrente de uma sorte de ruptura entre a direção estratégica e estes últimos, uma extrema diferenciação ou atomização das estruturas internas em função da especialização do trabalho, e uma desconsideração relativa da ambiência externa em razão de uma sobrevalorização corporativa do interno. Estas características dificultam a a possibilidade de um projeto gerencial que enfatize a integração intra-institucional, a racionalidade econômica da missão específica e a negociação de uma rede de cuidados com os outros estabelecimentos da ambiência imediata. A perspectiva da démarche é promover um tipo de movimento cultural que contrabalance essas tendências, abrindo caminho para o desenvolvimento de uma forma de organização que se aproxime daquelas premissas ideais (Rivera, 1997; Artmann, 2002).

Mais especificamente, os objetivos da démarche seriam:

- promover um elo de ligação entre a gerência estratégica e os centros assistenciais, por meio da comunicação;

- definir a missão do hospital de acordo com o critério de oportunidade. Isto equivale a determinar preferencialmente um padrão de atividades que permita vantagens comparativas, ao mesmo tempo que oferece um serviço de qualidade aos usuários;

- buscar um lugar de comunicação, onde os atores-serviços possam chegar a definir um projeto coletivo;

- favorecer a integração do hospital em uma rede de oferta de cuidados estruturada com a preocupação da eficácia e da eficiência;

- promover um processo de transformação cultural progressiva, não necessariamente preso à busca de objetivos instrumentais, imediatos.

Do ponto de vista da estratégia microeconômica, este enfoque questiona uma visão homogênea da excelência, representada pela intenção de firmar, na mesma 
escala; todas as áreas de atendimento. A alternativa a esta visão seria a de trabalhar a vocação de cada estabelecimento dentro da perspectiva da complementariedade. A melhor estratégia para que um estabelecimento possa obter vantagens comparativas é a diferenciação, que corresponde à definição de suas áreas de excelência, com o objetivo de priorizá-las, de expandi-las, negociando com a rede de serviços o atendimento das clientelas não incluídas nestas áreas (típicas de atividades de menor desenvolvimento relativo). A opção nuclear do enfoque é a idéia de procurar transformar a concorrência frontal em colaboração, buscando as competências distintivas de cada hospital e negociando as missões entre os diferentes estabelecimentos.

$\mathrm{Na}$ perspectiva político-organizacional, o enfoque se opõe a uma definição normativa e tecnocrática de diretrizes, apostando na via da responsabilização dos atores, que implica no desenvolvimento de processos comunicativos e de negociação internos e externos, que redundem em acordos relativos aos projetos assistenciais pertinentes a uma rede. Em relação à estrutura organizacional, o enfoque postula a necessidade de intensificar as estruturas em rede interna e o diálogo multidisciplinar, promovendo a busca de transversalidades.

Apresentaremos, a seguir, vários elementos da proposta geral de gestão estratégica de Crémadez, a partir de um resumo comentado de sua obra:

- as premissas gerais, de ordem teórico-conceitual, do enfoque;

- o método de análise estratégica da missão das especialidades médicas;

- $\quad$ as estratégias básicas de obtenção de vantagens comparativas;

- a proposta de estrutura organizacional em rede;

- a questão da padronização de processos de trabalho visando a organizar a diversidade;

- uma proposta geral de análise e planejamento da distribuição de recursos humanos.

\section{Premissas Teóricas Gerais do Enfoque de Crémadez}

\section{Dinâmica organizacional e prática decisional das organizações profissionais de saúde}

A partir de Mintzberg (1982), Crémadez e Grateau determinam, detalhadamente, as principais características de uma organização profissional:

- Primazia do centro operacional: engloba um grande número de unidades bastante independentes, altamente especializadas, que reconhecem um ambiente diferenciado. Significa que estas unidades são mais importantes 
do que outras estruturas/instâncias organizacionais, reunindo suficiente saber e autonomia para tomarem suas próprias decisões. Cada centro operacional se diferencia por ter as próprias normas, procedimentos, usuários diferenciados e por estar ligado a diferentes entidades ou sociedades de especialistas (sociedade de cardiologia, sociedade de oftalmologia, ortopedia, de cirurgiões etc.).

- Preponderância do relacional: o trabalho é coordenado por meio do ajustamento mútuo, que pressupõe relações espontâneas e informais entre responsáveis, e do processo de padronização das profissões, pois a formação profissional e a socialização em sociedades especializadas contribuem para a posse de um patrimônio comum de saber, métodos e comportamentos. Esta característica reforça a autonomia profissional e um fraco sentimento de pertinência à organização.

- Debilidade da tecnoestrutura: a tecnoestrutura tem um fraco poder de ingerência sobre os processos operacionais da organização, a não ser na dimensão econômica.

- A logística é importante: o tipo de coordenação respectiva é procedural e por resultados e se efetiva de maneira centralizada. A lógica diferente dos universos médico e logístico pode gerar problemas de coordenação. A expansão da importância dos meios logísticos tipicamente médicos, como equipamentos e tecnologias hospitalares, cria lutas de influência entre administradores e médicos, bem como conflitos dentro da própria comunidade médica.

- Ausência de linha hierárquica rígida: a direção não tem a capacidade nem a competência para dirigir diretamente os chefes dos vários serviços. Atua indiretamente através da tecnoestrutura e dos serviços funcionais e/ou de instâncias de negociação.

O resultado dinâmico desta caracterização é uma forte diferenciação (Lawrence \& Lorsch, 1973), com várias dimensões:

- Diferenciação entre o mundo administrativo e o mundo assistencial: o primeiro está mais voltado para as instâncias de regulação, persegue objetivos quantitativos e econômicos, inseridos em uma perspectiva política, articulando curto e longo prazos. Já o segundo busca objetivos mais qualitativos, ligados a uma perspectiva de mais curto prazo, representada pela demanda dos pacientes. Está centrado sobre tarefas particulares que requerem a mera aplicação de meios consagrados. Estas atividades são exercidas de maneira liberal e têm uma fraca pertinência organizacional. O nível hierárquico, neste segundo caso, está determinado pela competência. 
- Diferenciação entre logística e centro operacional: a logística é organizada de maneira mais mecanicista e coordenada segundo critérios econômicos, de forma centralizada. O mundo médico é descentralizado e organizado segundo o saber próprio e especializado. Há choques entre administração e centro operacional no que diz respeito ao controle dos equipamentos e das tecnologias médicas descentralizadas.

- Diferenciação no centro operacional: há uma forte especialização horizontal, bem como uma diferenciação no interior de cada serviço entre as várias categorias de profissionais e entre corpo médico e paramédico.

Para Crémadez, a diferenciação é fonte de eficácia. É necessário respeitar algum grau de diferenciação, valorizar as diferenças sem buscar a homogeneidade ou simetria. Deve-se, porém, compensar os efeitos negativos da diferenciação desenvolvendo formas de integração de uma força equivalente.

Como resultado de suas características estruturais e dinâmicas, a prática decisória das organizações profissionais é incrementalista: as decisões são tomadas em série, em função do poder de pressão momentâneo dos vários atores hospitalares, sem uma perspectiva de conjunto. Há uma justaposição de objetivos. Não se verifica, assim, o processo de formulação de uma estratégia anterior (ex-ante). Não se busca ou não se quer uma estratégia, esta seria o resultado emergente de decisões de natureza mais operacional, pontual. A estratégia emergente é o fruto de uma inflexão ou de um deslocamento discreto da estratégia anterior sob a influência de decisões sucessivas não geradas de forma global (Nioche, 1997).

Outros resultados da dinâmica organizacional dos estabelecimentos de saúde referem-se ao fechamento em relação ao exterior (ao ambiente) e um baixo sentimento de pertença à organização por parte dos profissionais médicos. $\mathrm{O}$ ambiente é percebido como um constrangimento e os que nele atuam adotam uma postura reativa. A organização está centrada sobre si mesma.

O processo de decisão estratégica procura inverter essas tendências. Objetiva ajudar a criar uma cultura em que o ambiente seja percebido como recurso; em que se antecipem as tendências do ambiente de modo a atuar criativamente sobre ele e onde a organização desenvolva sinergias e parcerias de modo a trabalhar dentro da premissa de redes de colaboração.

\section{A prática decisional da gestão estratégica}

A gestão estratégica rompe com a dissociação entre o estratégico e o operacional, buscando diluir essa divisão vertical. O poder de decidir sobre o aproveitamento de uma oportunidade está amplamente difundido pela organização e 
não mais concentrado na cúpula. A direção assinala as grandes orientações, os valores centrais do projeto organizacional, mas não define a estratégia propriamente dita, que depende da articulação de todos os atores organizacionais.

A gestão estratégica introduz um tipo de planejamento contínuo, flexível e ajustado, buscando concretizar um conjunto coerente de projetos. Traz à tona a questão dos objetivos por oposição a uma lógica de meios. É uma prática decisional mais integradora. Ao envolver o maior número de atores do centro operacional, procura reduzir ou, pelo menos, tornar transparente, o jogo político interno, por intermédio de vários fatores:

- A gestão estratégica teria a virtude da transparência representada pela utilização, no processo decisório, de dados objetivos sobre a atividade de base, e não de meras impressões de fundamentação relativa.

- A transparência estimula a comunicação desde a concepção das bases de coleta de informação, que pode cristalizar-se em uma nomenclatura comum de classificação e avaliação dos atos médicos, das patologias, modos de atendimento etc. O compartilhamento dessa informação contribuiria para uma harmonização da linguagem entre os atores de base da organização.

- É possível reconstituir, através do processo da segmentação estratégica, os diferentes domínios de atividade desmembrados pelo jogo da distribuição territorial do poder. As conseqüências desta transparência são várias: os diferentes atores da mesma unidade de base podem raciocinar a partir de uma visão mais clara e compartilhada de sua atividade, para prever sua evolução e conseqüências. A identificação, a partir da análise estratégica dessa segmentação, de domínios de atividades compartilhados permite explorar as sinergias, elaborar alternativas e estratégias comuns; a verificação de relações entre serviços permite estabelecer pontes entre os mesmos. Cria-se, ainda, uma interação permanente entre o mundo administrativo e o médico, pois o sistema de informações médicas e determinados tratamentos de dados passam a incorporar preocupações estratégicas, o que permite associar o raciocínio gerencial com o técnico.

- A gestão estratégica seria uma pedagogia de avaliação, na medida em que introduziria a preocupação com os resultados, para além de uma conduta pautada na aplicação de meios. A questão de como atender às expectativas dos usuários de uma rede estaria no centro de uma política de avaliação sistemática, como cultura a ser desenvolvida. O processo de avaliação estratégica se traduz, pela via da negociação, em projetos de ação, que se constituem em um estímulo à mudança, pois esse processo suscita uma inquietação natural em relação aos resultados possíveis.

- A gestão estratégica ajuda a formalizar as avaliações e os comentários que as justificam, gerando bases mais sólidas para dirimir litígios ou divergências 
de interpretação. A formalização é um elemento capital da comunicação e da coesão entre as diferentes categorias de profissionais.

- A gestão estratégica explora a diversidade, pois ensina a aceitar a possibilidade de abandonar a posse de uma tecnologia ou de um equipamento, quando não constituem competências distintivas de um serviço ou do hospital, e quando a eles se tem acesso através de sinergias e parcerias, de modo a se concentrar no estudo de formas alternativas de tipo de atendimento que podem valorizar o serviço e, ao mesmo tempo, ser úteis para os usuários.

- A gestão estratégica introduz o raciocínio dos custos de oportunidade ao levar em conta as necessidades dos outros e o grau de satisfação global obtido pela organização. A aplicação de um recurso a uma atividade deve ser justificada pelo maior ganho comparativo atingido relativamente a usos alternativos. As diferenciações, representadas pelo aprofundamento de competências distintivas, são estimuladas na medida em que se subordinam a uma perspectiva de maior eficiência e eficácia globais, considerando o sistema ou a rede.

- A gestão estratégica introduz a necessidade de estimular projetos que permitam a captação de recursos adicionais, o que pode ajudar a limitar conflitos de poder e a viabilização de projetos que, de outra forma, teriam de ser abandonados ou adiados.

A gestão estratégica pretende, assim, arbitrar pelos custos de oportunidade para criar uma solidariedade.

\section{A crise de identidade e a necessidade de renovar o contrato psicológico}

A identidade organizacional é um correlato francês do conceito de cultura. Este último englobaria as representações sociais compartilhadas sobre a organização e sua missão, dados sua história e seu papel na sociedade. O conceito de identidade acrescentaria, a esta visão integradora, uma dimensão oculta pela cultura: a dos jogos de poder dos atores e de seus mecanismos psíquicos. Considera-se cultura, nesta perspectiva, como "significante" da identidade e identidade, como algo que recupera a função ideológica das representações organizacionais e sua lógica de poder (Strategor, 1997). A identidade é um tipo de lógica coerente de uma organização, uma visão coletiva, partilhada, procedente de influências internas e externas. Ela se inspira em paradigmas e gera paradigmas que condicionam a vida dos indivíduos no interior da organização. Está na base de uma sorte de contrato psicológico entre cada indivíduo e a organização que define a natureza e a força de sua identificação com ela. 
A erosão de certos paradigmas tradicionais contribui para criar uma crise de identidade organizacional. O contrato psicológico que liga os indivíduos à organização se enfraquece como resultado do impacto da mudança de diversos paradigmas: o da Medicina, do serviço público e o paradigma profissional.

- A mudança do paradigma da Medicina: há uma especialização e concentração crescente de atividades e de meios tecnológicos em grandes estruturas hospitalares, que demanda, de forma crescente, uma intervenção do tipo gerencial. Diminui o estilo de exercício liberal da profissão e intensifica-se o controle administrativo dessas estruturas. Ao mesmo tempo que o trabalho médico se insere em estruturas burocráticas, a medicina passa a ser vista de uma nova perspectiva. Uma atuação médica eficaz passa a supor uma articulação entre a medicina orgânica/positivista e um enfoque ecológico ou ambiental. A oposição entre generalistas e especialistas perde sentido. O papel do médico agindo isoladamente vai sendo substituído pela atuação em equipe. As parcerias se tornam indispensáveis, assim como a concepção de novas formas de hospitalização. A busca por solidariedade entre os atores ocupa o centro das atenções.

- A mudança do paradigma do serviço público: a redução dos recursos leva ao questionamento acerca da possibilidades eqüitativas do serviço público, ou, como diríamos no Brasil, sobre seu caráter universal. Atender a todos igualitariamente passa a ferir o princípio da equidade, pois dificulta o acesso para determinadas camadas da população. Para muitos, o serviço público transformou-se na defesa de monopólios, atuando com excessiva independência (acarretando situações de arbítrio e de anonimato) e que tende a se reduzir, como conceito, a uma ideologia tecnocrática. Postula-se que o serviço público deve passar a aceitar a concorrência, a avaliação, a necessidade da escuta dos usuários, a abertura ao ambiente. Deve tornar-se internamente competitivo (racionalizando seus recursos) e trabalhar em rede. Privilegiam-se também a idéia da contratualização, bem como o estabelecimento de formas de cooperação e parcerias.

- A mudança do paradigma do profissional: a experiência deixa de ser a base essencial da competência profissional. A veloz renovação dos conhecimentos e das tecnologias torna obsoletos os recursos cognitivos anteriores. Isto provoca um crescimento da especialização e uma regressão da autonomia dos especialistas. A complexidade técnica crescente provoca uma interpenetração maior entre o técnico e o econômico. Diante desse quadro, a formação tradicional, mais artesanal, de acompanhamento de um profissional mais antigo, perde importância relativa. A formação e atualização permanente torna-se uma das chaves da competência profissional; a possibilidade de operar reorientações profissionais (mudança de especialidades) torna-se capital, tanto para o desempenho das carreira individual como para a eficiência organizacional. 
Os principais traços da identidade organizacional postos em questão seriam: a não explicitação dos projetos organizacionais, a justaposição de objetivos; o isolamento dos profissionais e dos serviços; a recusa à avaliação das competências; o corporativismo profissional; o estilo liberal de exercício profissional; a informalidade; a predominância dos critérios técnicos sobre os econômicos; a marginalização da gerência; a pouca preocupação com o ambiente externo, entre outros.

Essas mudanças criam uma crise de identidade, que acentua sentimentos e reações negativas, como a contestação dos médicos como grupo dominante, a recusa a escolher prioridades e o bloqueio de iniciativas, que substituem a vontade de empreendimento dos mesmos profissionais e a regulação de conflitos pelo crescimento. No plano externo, o hospital torna-se mais reativo, superestima restrições de recursos e passa a olhar o futuro com inquietação. Fazem parte do pano de fundo desta crise as necessidades de fortalecer a regulação administrativa e de introduzir critérios econômicos de gestão dos centros operacionais, o que ameaça a autonomia.

A gestão estratégica pretende operar movimentos que permitam a renovação do contrato psicológico entre os profissionais e a organização, em nossos dias bastante enfraquecidos. O impacto sobre a identidade organizacional compreenderia vários fatores:

- Ao formular um projeto de organização mais estruturado, com base na exploração de sinergias e de parcerias, a gestão estratégica busca colocar em evidência soluções (o que tem impactos psicológicos naturais) e escolher aquelas que permitem um maior ganho coletivo ao favorecer o compartilhamento de recursos. A gestão estratégica combina as estratégias individuais dentro de uma estratégia de conjunto, deslocando as atenções das atribuições para as contribuições. A formalização da informação, das análises e dos planos favorece a apreensão da organização por todos os atores. A instância reguladora (Ministério da Saúde) é convocada a decidir sobre objetivos explícitos e não somente sobre distribuição de recursos em estado de penúria. $\mathrm{O}$ próprio diretor do hospital fortalece sua posição ao ter de arbitrar, em última instância, o contexto de vários projetos médico-assistenciais.

- O processo de análise estratégica cria lugares de encontro, estimula a reflexão coletiva (intra e inter grupo profissional), distribui responsabilidades entre grupos, cria novas unidades, aumenta as interfaces externas. $\mathrm{O}$ sistema de poder, dividido e preso aos serviços, evolui para o estabelecimento de transversalidades e de interdependências. A natureza ao mesmo tempo técnica e econômica das decisões conduz à evolução das relações entre administradores e médicos no sentido da colaboração. Haveria mais integração e formalização. 
- O melhor conhecimento mútuo, com base na socialização de um sistema de informação, promove uma gestão negociada, que acentua a necessidade das sinergias e parcerias operacionais. O ambiente passa a ser o centro das atenções. Os vários agentes organizacionais passam a se visitar mutuamente, a conversar, a se encontrar mais. Os valores passam a ser questionados, trazidos à tona como fundamento das decisões. Determinados tabus como a competência alheia são relativizados. A avaliação estratégica justifica a necessidade de uma análise da competência global dos serviços em relação à capacidade de dar resposta aos usuários. A rigidez de posições corporativas cede lugar, em função da possibilidade do encontro, a posições mais flexíveis.

- O imaginário organizacional evolui, em síntese, para uma valorização da interdependências que compensa a reivindicação de autonomia, para uma apreciação positiva do sentido de bem coletivo da atividade. Os indivíduos se apropriam da organização com informação, formalização e análise e desenvolvem uma motivação para a ação. Sentem-se modelando e adaptando dinamicamente sua organização.

A renovação do contrato psicológico depende da mobilização de três alavancas:

- O papel da liderança: as situações de crise exigem a presença do poder de motivação do líder. Esta liderança deve anunciar a capacidade de assumir a iniciativa e de explorar novas regras do jogo. Deve comunicar com clareza, visando a fixar, focalizar progressivamente um novo modo de comportamento, guiado por um estado de espírito menos individualista, mais solidário, mais centrado na ação coletiva, que valorize as contribuições mútuas, a comunicação, que seja menos hierarquizado, menos prescritivo, mais aberto às expectativas externas, mais transparente. Esta liderança deve ajudar a projetar a imagem do sistema político não como um jogo de pressões aleatórias, mas como um processo de ação interativa consensual e contributiva.

- O papel da comunicação: a comunicação ajuda a criar uma linguagem comum e a integrar os discursos individuais em uma perspectiva global, de modo a aumentar a coesão social. A comunicação implica o reconhecimento do outro como legítimo outro, no reconhecimento das expectativas dos interlocutores, no reconhecimento da imagem que projetamos para os outros e na comparação entre essa imagem e o desejado. A comunicação exige uma releitura da organização para nos reconhecermos - como coletividade - no passado e para explorar determinados traços culturais que podem ser úteis para mudar, ou para identificar formas retardatárias de prática das quais podemos nos afastar positivamente. Comunicar nossa oferta de atividades é uma forma de fortalecer nossos compromissos diante dos demais integrantes da rede e de aumentar nosso nível de exigência. 
- A apropriação da organização pelos atores: sem uma apropriação da estratégia pelos atores, esta não irá em frente. Dada a característica processual, adaptável, nuançada, dos projetos dos vários serviços, torna-se necessário que os vários atores subscrevam uma carta de intenções estratégicas geral, que tenda a dar unidade às iniciativas locais, algo assim como o grande projeto de estabelecimento. Como entre o discurso e a real modificação de comportamentos há uma distância importante, é fundamental que se assuma a análise estratégica como um processo exploratório, iterativo e progressivo, como aprendizagem permanente.

\section{O modelo de mudança organizacional}

Este modelo de gerenciamento tenta articular a necessidade de racionalidade com a ampla participação dos atores da base organizacional. Opõe-se ao Modelo Racional de uma Ator Único (a direção), que busca apenas uma única solução ótima de natureza econômica, a partir de uma problemática que se pretende estruturada. Insere-se na perspectiva do Desenvolvimento Organizacional, que encara a mudança não como a gestão da passagem de um estado de equilíbrio para um estado de equilíbrio diferente, mas como a gestão do desequilíbrio que caracteriza toda organização dinâmica, desequilíbrio e movimento estando intimamente ligados. Na perspectiva do Desenvolvimento Organizacional, mudança e aprendizagem são fenômenos naturais e essenciais, de caráter permanente e não eventos induzidos ocasionalmente de fora. Esta perspectiva consiste em impedir a ingerência da hierarquia para que os atores organizacionais pesquisem os obstáculos ao bom funcionamento organizacional, que se identificam com freqüência com o comportamento interativo. Outra contribuição ao novo modelo de gerenciamento é a Análise Sociológica das Organizações, de Crozier (1977), que defende a necessidade de uma ampla participação para apoiar o processo de conquista do mundo exterior no potencial energético de atores autônomos que negociam um projeto solidário.

Este modelo é racional, pois acentua a necessidade de formular objetivos, pautados em uma raciocínio de custos de oportunidade e uma análise de tendências do ambiente exterior. É um modelo de negociação, participativo, de baixo para cima, que se apóia na formalização das análises, avaliações e estratégias e na utilização de um método de trabalho comum.

É um modelo propício à mudança, porque permite desde o início o encontro onde não havia encontro. 
Algumas características deste modelo:

- O processo supera o modelo: a coerência é fruto de ajustamentos sucessivos, de uma aprendizagem progressiva sobre a possibilidade de objetivos comuns, mesmo que parciais. Neste processo de aprendizagem, destaca-se a preocupação com a necessidade de uma atuação permanente sobre um ambiente complexo e evolutivo, de maneira não reativa.

- A organização é o produto das orientações: a organização se constrói a partir de planos de ação definidos coletivamente e de uma política de sinergias.

- As orientações provêm da base: em uma organização diversificada e achatada, a definição centralizada da estratégia é necessariamente redutora.

$\mathrm{Na}$ promoção do processo de mudança duas questões são vitais para Crémadez: em primeiro lugar, a necessidade de investimento pedagógico expressivo no território da metodologia, e de que os atores incorporem a idéia de que poderão manter o controle sobre o processo, dependendo os resultados de suas possibilidades; em segundo lugar, a necessidade de obter resultados rápidos e de que se consolide a idéia de que o distanciamento crítico em relação às competências profissionais ajudará a desbloquear situações inextricáveis.

Alguns princípios são muito importantes neste processo: ser transparente e argumentativo no processo de busca incessante do consenso, evitando apostar no antagonismo para contornar situações de impasse; evitar condutas de exclusão, mantendo a porta sempre aberta à discussão; explorar o poder de sensibilização do diretor, o qual deve explicitar com clareza sua vontade de mudança e assinalar as grandes linhas teóricas deste processo, considerando a satisfação dos usuários, a realização dos atores internos e um maior alcance da missão; dar-se o tempo necessário, considerando as particularidades de cada serviço e hospital, para que aconteçam processos de mudança; apostar na obtenção de resultados concretos para reforçar a crença na mudança no imaginário dos atores; fugir de um jogo em que um ator ganha e o outro perde, através da exploração das sinergias e parcerias, da socialização de meios; tornar os processos decisórios mais rápidos e combater a burocracia, para dar sinais evidentes de uma menor inércia organizacional.

Garantir uma viabilidade de permanência e continuidade para mudança dependeria de três fatores: a transferência da metodologia para os atores internos, com a substituição progressiva dos consultores externos; a evolução progressiva da tecnoestrutura; e o investimento em formação. 


\section{O Método}

As fases do método e seu conteúdo geral são:

- A análise do existente: corresponde ao diagnóstico do método.

- A segmentação: esta etapa corresponde à definição dos principais agrupamentos homogêneos de atividades, considerados aqueles que apresentam uma mesma problemática estratégica.

- A análise do valor e da posição competitiva de cada um dos segmentos resultantes dos agrupamentos de atividades: o valor corresponde ao interesse relativo ou ao nível de prioridade relativo que os segmentos teriam para a especialidade em função de uma política geral e depende do interesse na alocação de recursos. Um critério genérico na aferição desse valor está representado pela capacidade potencial de atração de clientela ofertando um atendimento de excelência, com eficiência; a posição competitiva é avaliada considerando-se o grau de controle sobre os chamados fatores-chave de sucesso (FCS), que corresponderiam a vantagens ou situações positivas necessárias para se ter êxito em uma atividade.

- A construção do porta-fólio de atividades, visando à definição da estratégia geral de atuação ou dos objetivos: o porta-fólio é um gráfico cuja abscissa está representada pela posição competitiva do estabelecimento e cuja ordenada representa-se pela capacidade de atração (valor) dos segmentos.

- O Plano de Ação, visando a atingir os objetivos a partir das estratégias, definidas em termos de três possibilidades: priorizar o desenvolvimento de um segmento; estabilizá-lo; reduzir o recrutamento de clientela ou recortar o segmento.

- A montagem dos indicadores de monitoramento do plano.

Vejamos o conteúdo mais específico de cada fase.

\section{A análise do existente}

O diagnóstico é administrativo e médico.

O diagnóstico administrativo é do tipo tradicional, com informações como: tempo médio de permanência, número de ingressos, pessoal médico e paramédico, estrutura física, perfil da demanda etc.

O diagnóstico médico compreende:

- relação de patologias atendidas por disciplina médica, ordenadas de acordo com uma complexidade crescente; 
- relação de tecnologias utilizadas por disciplina, ordenadas de acordo com a complexidade;

- cruzamento entre patologias e tecnologias, identificando-se a incidência das tecnologias sobre as patologias;

- relação das modalidades de atenção, considerando-se quatro critérios:

- se as atividades visando às patologias são ou não programáveis ou eletivas;

- se a intervenção sobre as patologias demanda consulta ambulatorial e/ ou hospitalização;

- o tipo de hospitalização requerida: o tempo da internação requerida;

- se as patologias listadas demandam um tipo particular de capacidade diagnóstica ou de exploração funcional (plateau tecnique) existente no serviço ou fora dele.

A fase diagnóstica inclui ainda a relação dos concorrentes e dos parceiros, bem como o desenho da rede de cuidados.

A rede de cuidados é um quadro que pretende levantar as atividades por segmento, divididas em atividades de diagnóstico, tratamento e acompanhamento, realizadas no serviço, em outros serviços do mesmo hospital e na rede (interfaces externas). (Ver Figura 1).

Figura 1 - Rede de cuidados (quadro adaptado) - (filière de soins).

\begin{tabular}{|l|l|l|l|}
\cline { 2 - 4 } \multicolumn{1}{c|}{} & Diagnóstico & Tratamento & Acompanhamento \\
\hline Serviço & & & \\
\hline Hospital (outros serviços) & & & \\
\hline Rede (interfaces externas) & & & \\
\hline
\end{tabular}

Fonte: UAS-CHRU, 1995.

O quadro Rede de Cuidados é um instrumento que possibilita identificar superposições e complementaridades eventuais entre os três níveis de serviços referidos, possibilidades de concorrência e também carências de atividades. 
O objetivo maior desta fase diagnóstica é proporcionar elementos para a fase seguinte, que consiste em segmentar os serviços segundo uma lógica que veremos a seguir.

\section{A segmentação estratégica}

A segmentação implica definir coletivamente, no nível de cada serviço, agrupamentos homogêneos de atividades, definidos como aqueles pólos de atividades em que predomina a identidade de elementos do ponto de vista de sua problemática estratégica. Neste processo, devem-se reduzir ao mínimo possível os fatores de discrepância. Caso se notem grandes diferenças, devem-se realizar novas divisões de categorias.

O objetivo central da definição de segmentos homogêneos é criar categorias que permitam uma análise estratégica representativa, tendo em vista que o hospital é uma instituição multiproduto, onde nem sempre todos os grupos de atividades apresentam o mesmo desenvolvimento ou o mesmo valor estratégico. Considera-se, então, que cada segmento reconhece um ambiente concorrencial específico.

A fase da segmentação é uma análise multicritérios, em que as diferentes atividades são submetidas ao crivo de vários critérios específicos:

- As patologias apresentadas pelos pacientes: tipo e localização da afecção; grau de complexidade; imbricações entre patologias.

- As características do processo de atendimento: necessidade de internação convencional ou específica (leitos de isolamento), grau de programação ou de eletividade da atividade.

- As características das tecnologias utilizadas: necessidade de dispor de uma estrutura técnica (de apoio diagnóstico, terapêutico ou de acompanhamento) específica; tamanho do investimento realizado ou a ser realizado; acesso à estrutura técnica geral.

- As competências necessárias: grau de sofisticação dentro da especialidade; multidisciplinaridade (recurso às competências de diversos especialistas).

- A concorrência: número de instituições e de profissionais que exercem a atividade e meios disponíveis.

- Tipo de população envolvida: idade, sexo, categoria sócio-profissional específica, ativo ou inativo.

- O lugar da atividade na rede de cuidados: urgência, diagnóstico, atenção, acompanhamento, educação sanitária, prevenção. 
Podem-se reunir estes critérios em quatro grupos:

- as patologias (enfarte, insuficiência cardíaca, arritmias etc., na cardiologia);

- as tecnologias (radiologia, ultra-som, laser etc.);

- os modos de atenção (internação convencional, consulta ambulatorial, hospital-dia etc.);

- população (alcoólatras, idosos, crianças, mulheres, entre outros).

Pode ser interessante uma análise progressiva, começando pelos critérios médicos patologia e tecnologia, mas busca-se criar agrupamentos homogêneos do ponto de vista dos quatro critérios, e não de um em particular. A definição é situacional, tendo em vista que os envolvidos podem privilegiar um determinado critério ou dois. Em geral, priorizam-se, de acordo com a experiência, os critérios médicos. Não se trata de descobrir uma estrutura universal e geral, que serviria de referência para organizações que oferecem atividades análogas, como se organiza e recorta o campo de uma disciplina científica. A definição dos segmentos está influenciada estrategicamente pela necessidade de apresentar, desde o início, os conjuntos de atividades típicos de cada hospital que contribuem para sua diferenciação. A forma como as atividades são organizadas previamente em função de uma dada cultura também é determinante de recortes particulares. A subjetividade é inerente à segmentação na medida em que esta depende do olhar que os interessados dirigem sobre suas atividades e o ambiente externo específico, condicionado pela identidade cultural da organização.

Cada um destes quatro ângulos de aproximação destaca, em maior ou menor medida, a dimensão médica, organizacional ou social da atividades. Assim, se os dois primeiros são estritamente de ordem médica, o terceiro (processo de atendimento) trata do contexto organizacional oferecido aos pacientes, ao passo que o quarto (população) está mais centrado nas necessidades de uma categoria específica de indivíduos. A escolha respectiva traduz escolhas estratégicas diferentes em termos da pesquisa de vantagens competitivas:

- Um segmento centrado nas patologias traduz a adoção de uma posição ampla na rede de cuidados, correspondendo a uma oferta diversificada e a processos de atenção variados (consultas, explorações funcionais, cuidados, acompanhamentos etc.).

- Um segmento centrado na tecnologia prioriza uma oferta específica correspondente a uma posição mais restrita e mais pontual na oferta de cuidados, seja no nível do diagnóstico, seja no nível curativo, ou no de acompanhamento (técnica particular de reeducação, por exemplo). Em geral, escolhese um segmento tecnológico quando se trata de técnicas e equipamentos de uma certa complexidade, de uso não indiscriminado, que englobam um 
conjunto característico de patologias e que constituem vantagens comparativas ou "exclusividades".

- Um segmento centrado em um modo de atenção privilegia o contexto dentro do qual se encontra o paciente e destaca a resposta a certas necessidades ou constrangimentos a partir dos quais ele pode julgar se os serviços que lhe são oferecidos (urgência, programação, duração...) estão adaptados às suas necessidades.

- Um segmento centrado em uma população específica de pacientes privilegia as expectativas ou as necessidades de ordem sanitária, mas também de ordem social, de um grupo de indivíduos aos quais podemos oferecer um serviço diferenciado, adaptado à sua especificidade.

O destaque dado a uma dimensão, patologia, por exemplo, não exclui, de maneira alguma, as outras dimensões: tecnologia, população, modo de atenção, que podem apresentar-se de maneira subordinada. Estes critérios não predominantes complementariam a descrição das características dos segmentos e ajudariam a refletir sobre o aspecto das sinergias. Em uma instituição, podem-se adotar, ao mesmo tempo, segmentos estratégicos que obedecem a critérios predominantes diferentes.

A segmentação estratégica é um método que permite apreender uma realidade complexa e decompô-la em subconjuntos mais simples de entender. Para constituir estes subconjuntos, privilegiam-se certos fatores comuns às atividades que os compõem, subordinando os fatores que as diferenciam. Assim, constrói- se um modelo redutor da realidade. A segmentação estratégica apresenta um risco importante se perdermos de vista as simplificações que ela oportuniza. Os segmentos não são estanques, tendo interfaces que devem ser estudadas. A identificação de problemáticas transversais é, então, indissociável da segmentação. Isto permite dar uma coerência de conjunto às atividades segmentadas anteriormente.

Quando o ponto de partida da segmentação é a estrutura organizacional, fica evidente a presença de relações entre os serviços, ligações freqüentemente escamoteadas pela dinâmica e diferenciação organizacional ou sacrificadas no altar da preservação dos territórios. As problemáticas transversais estariam geralmente ligadas:

- a oportunidades de colaboração entre disciplinas completamente afastadas no passado (por exemplo, o estudo do sono pode progredir através da associação de competências da pneumologia, da neurologia e da psiquiatria).

- à desestabilização, por inovações tecnológicas, de fronteiras classicamente reconhecidas, que provoca com freqüência guerras de apropriação (por exemplo, entre a endoscopia e a radiologia intervencionista). 
- à colocação em evidência de dependências mútuas no seio de uma mesma rede de cuidados (entre a cirurgia e a medicina para o diagnóstico e depois para o acompanhamento de certas formas de câncer ou de transplante, por exemplo).

- à evidência de necessidades comuns a várias disciplinas diferentes (avaliação dos desafios da nutrição, por exemplo).

O tratamento das problemáticas transversais pode-se traduzir, seja por uma nova segmentação: remodelagem do conteúdo dos segmentos existentes, aparecimento de novos segmentos (exemplo: o vascular, em cardiologia), seja pela delimitação de novos campos de sinergias (exemplo: entre o segmento vascular da cardiologia e o da neurologia).

A sinergia é o excedente de eficácia ou eficiência resultante da operacionalização conjunta de duas ou mais atividades ou segmentos distintos. A identificação das sinergias é fundamental sobre o plano estratégico, pois permite dar, mais uma vez, uma unidade ao conjunto dos segmentos reunidos em uma mesma organização. As sinergias definem as linhas de força da colaboração a se instaurar entre os diferentes componentes da organização, ou seja, a aplicação em comum dos recursos a fim de que a gestão das interfaces entre os segmentos seja fonte de vantagens competitivas. Se a detecção das sinergias é de ordem estratégica, a mobilização das mesmas pode ser também de ordem organizacional, através da adaptação das estruturas no sentido amplo, principalmente através da mobilização de estruturas de integração.

É importante assinalar que o processo de segmentação nunca é definitivo ou fixo e não se prende ao pré-existente, havendo a possibilidade de surgimento de segmentos virtuais. Durante este processo, novas e interessantes formas de segmentar podem surgir. Assim, uma segmentação iniciada através do predomínio do critério patologia pode mostrar-se extremamente extensa e pouco operacional e evoluir posteriormente para uma segmentação prioritariamente por tipo de atendimento, com a inclusão subordinada dos critérios tecnologia e população. As áreas de diferenciação estratégica de um hospital podem mudar ao longo do tempo, condicionando novas formas de segmentação que devem ser tratadas como um processo de aproximações sucessivas. Este processo é iterativo, progressivo e exploratório.

Daremos aqui alguns exemplos:

Segmentos do Hospital Psiquiátrico Philippe Pinel-SMS-Rio de Janeiro

- Ambulatório de Adultos

- Centro de Orientação Infanto-Juvenil (COIJ)

- Cais (Hospital-Dia de Adultos)

- Núcleo de Assistência Integral à Criança Autista e Psicótica (Naicap-Hospital-Dia de crianças) 
- Enfermarias A + B (psicóticos/pacientes graves)

- Unidade de Tratamento de Alcoolistas (UTA)

- Recepção e Emergência

- Laboratório (especializado em psiquiatria)

- Serviço de Imagem Cerebral

Esta segmentação está baseada fundamentalmente no critério tipo ou modo de atendimento, embora se apresentem recortes referentes a outros critérios, como, população (adulto/criança), patologia (UTA) e tecnologia (Serviço de Imagem Cerebral).

Segmentos da Cardiologia do Hospital da Lagoa-SMS-Rio de Janeiro

- Doença Arterial Coronariana (DAC)

- Arritmias

- Síncopes

- Cardiopatias Congênitas

- Hemodinâmica Intervencionista

- Hipertensão Arterial

- Cardiomiopatias

Esta segmentação é clássica, predominando amplamente o critério patologia, com a presença subordinada do critério tecnologia - hemodinâmica - , que reúne atividades que incidem sobre algumas das patologias que definiram segmentos (configurando uma superposição).

\section{Análise do valor de cada segmento}

A determinação do valor implica analisar cada segmento segundo vários critérios/subcritérios, dos quais destacamos:

- $\quad$ estado atual e perspectivas do mercado;

- barreiras à entrada de novos concorrentes;

- sinergias;

- $\quad$ grau de motivação interna;

- oportunidades do ambiente;

- $\quad$ potencialidades do segmento.

O objetivo central da análise do valor é hierarquizar os segmentos por meio de uma ponderação de critérios e de uma notação relativa. 
Cada critério geral teria um peso determinado, em termos percentuais, na fixação do valor do segmento (assim como os subcritérios específicos). Este peso é variável, situacional e referente à especialidade escolhida, ainda que esta ponderação relativa possa variar, para uma mesma especialidade, no caso de hospitais diferentes. Contudo, o peso expresso em percentuais permanece uniforme para a especialidade do hospital em foco, bem como para todos os seus segmentos. Esta ponderação corresponderia à importância relativa que cada critério teria para a comunidade de profissionais envolvida na análise estratégica segundo a aplicabilidade relativa dos critérios. Definido o peso relativo de cada critério, procede-se a um sistema de notação, atribuindo-se uma nota de 0 (zero) a 20 (vinte) por critério a cada segmento analisado. Esta nota consensuada corresponderia a uma visão prospectiva de como cada segmento se comportaria em relação a cada critério. Isto é, qual seria o nível de sinergia potencial? Quais as perspectivas de que cresça ou se desenvolva? Que potencial de captação de clientela e de desenvolvimento de pesquisa e de ensino é possível estabelecer? etc. O valor global do segmento será aferido em função das notas por critério e de seu peso específico, chegando-se a um score específico por segmento.

Passaremos a discutir brevemente o conteúdo destes critérios, à luz do material colhido em Lille, França, na UAS-CRHU (1995 a e b), bem como a partir da adaptação feita para a realidade brasileira (ver Anexo).

Em relação ao mercado, consideram-se as perspectivas de desenvolvimento, o risco de flutuação e a intensidade da concorrência.

As perspectivas de desenvolvimento referem-se à possibilidade de crescimento futuro dos segmentos de uma especialidade, considerando-se o cenário epidemiológico-social e o cenário tecnológico. Deve-se considerar que a evolução das técnicas de diagnóstico e de terapia podem contribuir para aumentar ou diminuir a demanda de serviços.

É importante a análise do risco de flutuação das técnicas que refere-se à previsão da emergência de novas técnicas capazes de modificar sensivelmente a atividade a curto ou médio prazo.

A intensidade da concorrência corresponde à previsão do quantitativo de instituições e de profissionais realizando a mesma atividade e a sua expressão em termos do controle dos meios necessários à oferta da atividade em questão.

Inicialmente, uma alta expectativa de crescimento induzida pelos fenômenos epidemiológicos e tecnológicos, uma previsão de estabilidade na evolução das técnicas e a presença de poucos concorrentes contribuiriam para valorizar o segmento, ao garantir, em tese, mais mercado para a especialidade de um hospital. Mas esta análise pode ser relativizada, dependendo do contexto sanitário, social e político da região onde se encontra o hospital. 
Em relação às barreiras de entrada de novos concorrentes no mercado, considera-se fundamentalmente o montante do investimento envolvido no desenvolvimento dos segmentos e as possibilidades de ser rentável ou obsoleto. Um investimento elevado já realizado e a previsão de continuidade valorizam o segmento em uma situação específica, pois isto significa vantagens comparativas em relação a outras organizações que não tenham realizado o mesmo investimento - que pode ser visto como barreira à entrada no mercado.

Pode-se desdobrar este investimento em equipamentos e tecnologia, capacidade instalada, recursos humanos especializados etc. Pode-se, também, considerá-lo de maneira agregada, com prioridade para o componente tecnológico.

As sinergias referem-se à possibilidade de compartilhar equipamentos, tecnologias, capacidade instalada, apoio logístico, bem como a opinião especializada dos profissionais. Este critério é importante tanto do ponto de vista da economia de custos quanto da qualidade dos serviços. Considera-se também que o sinergismo com outros segmentos e especialidades de um mesmo hospital e o potencial de parceria com a rede são fatores que incentivam o surgimento de um mercado ou de clientela, valorizando, portanto, o segmento.

Deve-se avaliar o grau de motivação interna pela disposição do corpo profissional de uma especialidade em investir nos vários segmentos. Esta é uma variável de conteúdo subjetivo relacionada ao grau de interesse que as atividades comportam em função do status das mesmas, de sua complexidade e da particular formação e cultura dos médicos.

As oportunidades do ambiente incluem a possibilidade de trazer recursos externos desenvolvendo cada segmento, de melhorar a imagem externa da especialidade e do hospital, o interesse manifesto das autoridades sanitárias revelado pela disposição de outorgar financiamentos suplementares, bem como o potencial de inovação decorrente da possibilidade de transferência de determinadas tecnologias.

As potencialidades dos segmentos corresponderiam à capacidade de atração de clientela regional e local, assim como às de geração de atividades de ensino e de pesquisa.

A atribuição de uma nota ao segmento por (sub)critério está baseada na formulação de perguntas-chave. Por exemplo, a avaliação das perspectivas de desenvolvimento supõe as perguntas:

A atividade em questão irá progredir nos próximos anos?

- $\quad$ em função dos fatores de risco (idade, por exemplo) ou

- $\quad$ em função da evolução tecnológica ou do savoir-faire (novas terapêuticas)?

Uma nota alta corresponderia à previsão de um forte crescimento e uma nota baixa, à estimativa de uma diminuição importante. 
Apresentamos, a seguir, a matriz básica adaptada do quadro de aferição de valor (Figura 2).

Figura 2 - Matriz de avaliação do valor dos segmentos de especialidade.

Especialidade/Disciplina:

Segmento:

Avaliação do Valor do Segmento:

\begin{tabular}{|l|l|l|l|}
\hline \multicolumn{1}{|c|}{ Critérios de avaliação } & $\begin{array}{c}\text { Peso } \\
\%\end{array}$ & $\begin{array}{c}\text { Nota } \\
\text { (de 0 a 20) }\end{array}$ & $\begin{array}{c}\text { Score } \\
(=\mathrm{p} \mathrm{x} \mathrm{n})\end{array}$ \\
\hline Mercado & & & \\
\hline $\begin{array}{l}\text { • Crescimento } \\
\text { - Insco de flutuação }\end{array}$ & & & \\
\hline Valon ponderade concorrencial & & & \\
\hline Barreiras à entrada & & & \\
\hline Sinergias & & & \\
\hline Grau de motivação interna & & & \\
\hline Oportunidades do ambiente & & & \\
\hline Potencialidades do segmento & & & \\
\hline Valor do segmento & 100 & & \\
\hline
\end{tabular}

Fonte: Crémadez \& Grateau, 1992.

Em nossa experiência, a análise do valor é considerada segundo os seguintes critérios: possibilidades de crescimento; intensidade da concorrência; tamanho do investimento, como barreira à entrada; potencial de sinergias (internas ao hospital), potencial de parcerias externas; potencial local e potencial regional de captação de clientela; motivação interna; potencial de ensino e de pesquisa; contribuição para o projeto político ou para a grande missão do hospital; contribuição para a imagem externa. Estes critérios comportam subcritérios explicitados durante a aplicação do enfoque para tornar o cálculo mais fácil.

O resultado desta fase é uma descrição precisa da problemática específica do segmento. Este método, apesar de não partir da categoria problema, permite, nesta fase, ir ao encontro dos problemas específicos. Por exemplo: 
- muitos concorrentes identificados resultam em uma nota fraca no tocante à intensidade da concorrência, o que contribui para um valor de mercado relativamente menor;

- expectativa de poucos aportes externos compromete o item oportunidades do ambiente;

- o fraco desenvolvimento da pesquisa pode comprometer as potencialidades de desenvolvimento geral.

Para que os critérios anteriormente aludidos não sejam fundamentalmente bases de investigação, mas de avaliação, é necessário submetê-los a um processo de formalização rigoroso. Assim, a avaliação do valor deve ser realizada sobre bases idênticas para todos os segmentos de atividade que compõem um estabelecimento. Caso contrário, a avaliação não poderá mais resultar em escolhas estratégicas, pois a elaboração de cada uma das grades específicas estaria apoiada em valores e modos de apreensão do meio ambiente diferentes, o que impediria toda comparação significativa.

A formalização da grade de avaliação deve evitar ao máximo os riscos de interpretações divergentes. Assim, o título do critério deve acompanhar-se de uma definição precisa do conteúdo do critério, da maneira de avaliar (significado positivo da variação) e do modo de cotação que será utilizado. Freqüentemente o grau de maturidade da organização face à avaliação definirá a utilização de uma cotação numérica. A vantagem de uma cotação numérica é permitir ponderar os diferentes critérios e obter uma nota global mais facilmente.

Apesar de todas as precauções que se possam tomar, a indisponibilidade de certos dados, bem como o fato de que, em certos casos, os especialistas consultados estejam implicados na cotação fazem com que não se possa evitar uma boa dose de subjetividade. A única maneira de minimizar esta questão é fazer com que a cotação se efetue em um contexto de participação suficientemente amplo para que haja a necessidade de se obter um consenso.

\section{A Avaliação dos fatores-chave de sucesso e da posição competitiva}

A análise da posição competitiva ou estratégica do hospital corresponde à identificação dos fatores-chave de sucesso (FCS) e ao grau de controle relativo por parte do hospital. Os FCS servem para avaliar a capacidade do hospital para obter bons resultados em cada um dos segmentos de atividade, ou seja, para satisfazer a demanda do serviço correspondente em qualidade e quantidade. 
Os FCS correspondem às competências/tecnologias que se devem controlar para se ter êxito nas atividades em análise. A identificação destes fatores-chave é equivalente à definição situacional de elementos de capacidade discriminante, ou seja, de capacidades específicas de ordem relacional, tecnológica, financeira ou de competências, cujo controle garante posições de vanguarda.

Este conceito apresenta as seguintes características fundamentais:

- O que se deve indicar é o conjunto de fatores que promovem efetivamente o êxito, quer dizer, o que é valorizado pelo meio ambiente dos profissionais e dos usuários. As confusões mais freqüentes, às quais é necessário estar bastante atento, são: confundir FCS e norma profissional (interna ou não à organização), por um lado e fatores-chave de sucesso e competência disponível, de outro.

- O número de fatores considerados deve ser limitado; tudo é importante, mas somente alguns elementos são decisivos.

- O nível de competência requerida pode ser avaliado em termos absolutos (mínimo requerido de ordem normativa), mas o que importa é a competência relativa, quer dizer, o diferencial de competências que se estabelece com relação aos concorrentes.

- Os FCS não são invariantes. Sua composição evolui em função dos fenômenos que influenciam as expectativas dos usuários. Estes podem ter uma origem ambiental (fenômenos sobre os quais se pode freqüentemente agir, ao menos indiretamente) ou resultar dos esforços das organizações, em competição entre elas mesmas, que tornam discriminantes fatores considerados anteriormente como secundários. Quando, depois da cotação, o diferencial entre os concorrentes aparece como relativamente fraco, pode-se interrogar sobre a pertinência dos fatoreschaves de sucesso definidos. Com efeito, se todos os concorrentes estão próximos e obtém uma nota satisfatória, deve-se perguntar se o fator-chave de sucesso não pertence ao passado, se seu efeito discriminante pode estar já superado ou se as posições concorrenciais dependem de outros parâmetros. Por outro lado, se todos os concorrentes resultam mal cotados, é necessário se perguntar se não existe um desvio que opera entre a visão do especialista (seu sistema normativo) e a visão do usuário (suas expectativas).

A identificação dos FCS deve ser realizada apoiando-se ao máximo na observação do meio ambiente, analisando o que determina o sucesso de um concorrente considerado particularmente ameaçador, interrogando os interessados, sejam profissionais e usuários. Esta identificação é indissociável 
da identificação dos concorrentes e consiste em explorar, pela reflexão estratégica, certos dados de marketing, interrogando-se sobre a persistência das expectativas observadas e sobre os fatores suscetíveis de modificá-las.

O levantamento de dados sobre FCS se faz por referência ao lugar que se ocupa na rede de cuidados correspondente ao segmento estudado. Ocupar uma certa posição na rede de cuidados específica pode ser, em si, um FCS. Uma vez determinado o espaço a ocupar, convém mobilizar um certo número de recursos e de capacidades de controle para propor serviços percebidos como tendo uma qualidade superior aos de seus concorrentes. A obtenção dos FCS é fruto da pesquisa sistemática sobre tipo, qualidade e volume dos recursos que teriam um efeito discriminante sobre o desempenho relativo dos concorrentes envolvidos.

Para ser operacional, isto é, conduzir à formulação de planos de ação que permitam melhorar a posição concorrencial do estabelecimento sobre um segmento de atividade dado, é necessário que a formulação dos FCS seja precisa. Não se trata de dizer, por exemplo, "são necessários médicos competentes" mas de precisar qual é a competência que faz a diferença; ao invés de "são necessários equipamentos eficientes", identifica-se qual é o equipamento cuja detenção constitui uma real vantagem estratégica.

O que faz o sucesso é aquilo efetivamente percebido pelo consumidor dos serviços ofertados. O fato de que o universo da saúde seja um universo prescritivo complica certamente o problema na medida em que pode haver em certos casos dificuldades para conciliar as expectativas dos profissionais e as dos pacientes. É necessário envolver todas as partes, especialmente os usuários (aqui incluídos os profissionais usuários da rede), na pesquisa dos FCS e evitar assumir a postura dependente de confundir expectativas com normas técnicas de boa qualidade profissional. As ferramentas de informação do marketing, os estudos de imagem, de satisfação e de opinião constituem neste sentido um suporte precioso. É por isto que a dimensão relacional (parcerias, comunicação) é freqüentemente fonte de elementos discriminantes.

É importante salientar que, diferente do valor, os FCS não podem ser idênticos para todos os segmentos de atividade, pois representam a especificidade da atividade. E mais, uma grande semelhança nos FCS de diferentes segmentos deve conduzir a repensar a segmentação.

O objetivo central desta definição é hierarquizar as atividades (os segmentos) em função de sua posição concorrencial.

O método de análise consiste dos seguintes passos:

- $\quad$ identificação dos FCS;

- levantamento dos concorrentes; 
- ponderação dos FCS ou definição do seu impacto ou de seu peso relativo sobre a posição concorrencial o que consiste em distribuir 100 pontos entre os FCS em função de sua importância relativa;

- notação: ato de atribuir nota de 0 a 20 a cada FCS em função do grau de controle real dos mesmos, considerando o controle próprio e também o controle dos concorrentes/parceiros;

- determinação da posição relativa própria e dos concorrentes, através da comparação dos scores pertinentes (o score de cada concorrente é determinado a partir dos produtos do peso e da nota por FCS);

É importante assinalar aqui que a definição da posição competitiva dos concorrentes implica a falta de um conhecimento mais preciso da mesma, uma pesquisa complementar em parte in loco (acumulando-se dados objetivos sobre o controle dos FCS). Assim, evita-se a subjetividade excessiva e erros inerentes a uma mera simulação à distância.

A matriz de análise do controle dos fatores-chave de sucesso com alguns exemplos é a seguinte (Figura 3):

Figura 3 - Matriz de análise dos fatores-chave de sucesso (FCS). Posição competitiva.

\begin{tabular}{|l|l|l|l|l|l|l|l|l|}
\hline Segmento & \multicolumn{5}{|c|}{ Concorrentes - Referência } \\
\hline Fatores-chave de sucesso & Peso & Nota & A & B & C & D & E \\
\hline Competência laboratorial & & & & & & & \\
Cooperação cardiologistas & & & & & & & \\
Acolhimento & & & & & & & \\
Acompanhantes & & & & & & & \\
Disponibilidade scanner & & & & & & & \\
Animação rede generalistas & & & & & & & \\
\hline Score segmento & 0 & 0,00 & 0,00 & 0,00 & 0,00 & 0,00 & 0,00 \\
\hline Posição relativa & & & & & & & \\
\hline
\end{tabular}

Fonte: Crémadez \& Grateau, 1992.

\section{A construção do porta-fólio de atividades. A elaboração de uma visão de conjunto}

O porta-fólio de atividades é uma matriz de valor/posição concorrencial onde são posicionados os segmentos estratégicos de uma especialidade para se ter uma idéia de conjunto e de valor comparativo. Na prática, é um gráfico constituído pelo valor como ordenada e pela posição competitiva como abcissa. Cada segmento é representado por um círculo cujo tamanho representa o volume de 
produção relativo das atividades que ele representa, e sua posição sobre o mapa depende do score obtido quando da avaliação do valor e do grau de controle dos fatores-chave de sucesso o que define sua posição competitiva. O gráfico é dividido em quatro quadrantes, sendo os dois superiores correspondentes a segmentos de alto valor, e os dois inferiores, a segmentos de baixo valor. Os quadrantes à direita referem-se a segmentos de alta posição competitiva, e os da esquerda, a segmentos de baixa competitividade (Figura 4).

Figura 4 - Porta-fólio de atividades.

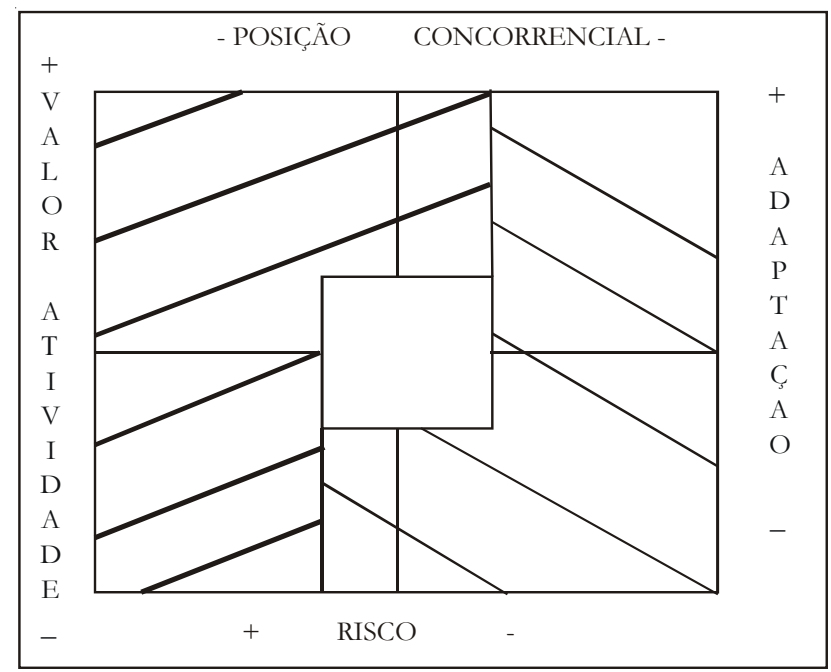

Fonte: Crémadez \& Grateau, 1997.

O exame do porta-fólio deveria permitir um diagnóstico rápido do risco estratégico a que o segmento se expõe, resultante da maior ou menor adaptação da oferta de serviços (valor da atividade) e do esforço requerido para suplantar a concorrência (a posição concorrencial). Também deveria sugerir as grandes linhas de ação de acordo com a posição estratégica no futuro.

O porta-fólio pode estar estruturado em três zonas:

- À direita, uma zona de fraco risco estratégico (tracejado fraco): a inadaptação dos serviços é, na maioria dos casos, compensada pela excelência da posição concorrencial.

- À esquerda, uma zona de forte risco estratégico (tracejado forte): a adaptação dos serviços é, no melhor dos casos, debilitada pela fragilidade da posição concorrencial. 
- No centro, uma zona de indiferenciação (branca), correspondendo às atividades medianamente valorizadas e não discriminadas com relação à concorrência: zona de forte incerteza estratégica.

Os exemplos que constam da Figura 5 foram retirados da obra de Crémadez \& Grateau (1997):

Figura 5 - Exemplos de porta-fólios de atividades.
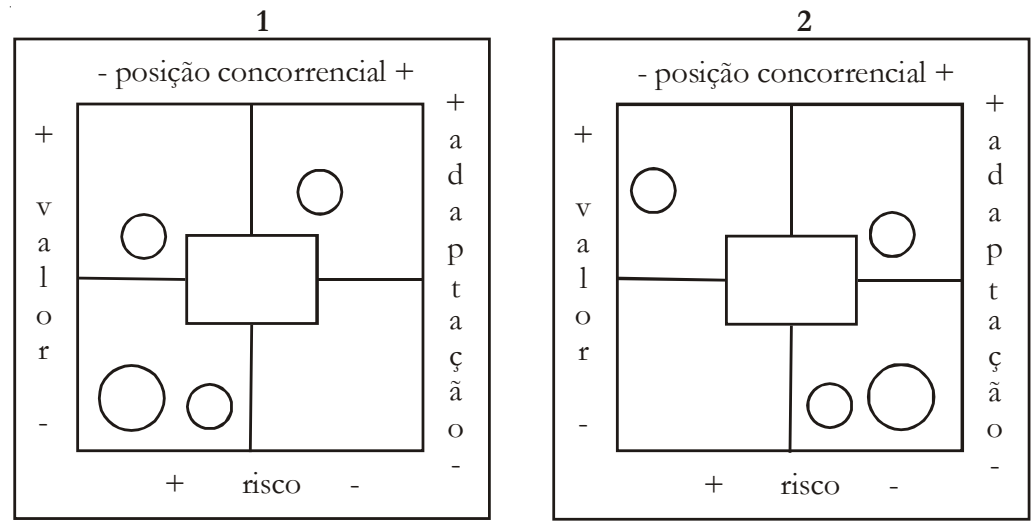

3
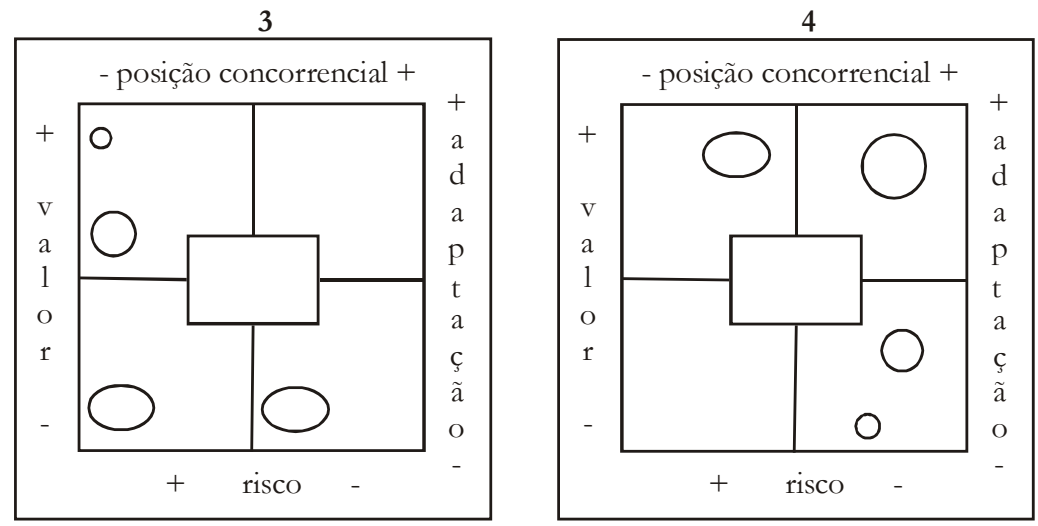

O porta-fólio número 1 representa alto risco, pois somente um segmento de atividade comporta uma boa posição concorrencial. Em contrapartida, está medianamente adaptado, pois cerca da metade do volume de atividade se destina aos segmentos mais bem posicionados em termos de valor. O principal problema da instituição será desvencilhar-se dos segmentos inadaptados a fim de canalizar seus recursos em direção aos segmentos mais bem adaptados, e notadamente em direção ao segmento que deveria ganhar em posição concorrencial. 
Nesta ocasião, será necessário analisar detalhadamente o conteúdo, em termos de população, patologia, tecnologia e de modo de atendimento do segmento mais importante (em volume de atividades) e não tão bem posicionado. Esta investigação permite "separar o joio do trigo" e revalorizar as atividades referidas favorecendo aquelas que, graças a uma orientação particular, fornecerão uma resposta mais adaptada as necessidades dos usuários. Trata-se, em certos casos, de se concentrar sobre a resposta específica a uma categoria de usuários que aparece como majoritária em um segmento considerado. Em outros casos, será conveniente adotar um modo de atenção mais bem adaptado e mudar de posição na rede de cuidados. Poderá ser o caso, ainda, de reduzir o número de patologias atendidas ou de concentrar-se sobre aquelas que correspondem mais à vocação do estabelecimento. Enfim, o encaminhamento poderia ser o de modificar as tecnologias utilizadas a fim de abrir um novo campo de ação. Assim, o desengajamento de um segmento de atividade não é sinônimo de abandono puro e simples; ele deve ser acompanhado de um plano de ação específico e, eventualmente, de um esforço de investimento.

O porta-fólio número 2 demonstra pouco risco: somente um segmento se coloca em posição concorrencial desfavorável. É, em contrapartida, pouco adaptado, já que o segmento que tem a pior posição concorrencial é precisamente aquele que representa o melhor valor. Entretanto, é difícil fazer evoluir este porta-fólio de forma constante, via redistribuição dos recursos entre os segmentos que o compõem. Com efeito, quando uma importante parte da atividade tem fraco valor, mas uma posição concorrencial mais forte, é difícil desembaraçar-se dela. Esta situação pode, em certos casos, traduzir uma insuficiência de difusão das tecnologias e/ou do savoir-faire. Uma das saídas pode ser então realizar a transferência dos segmentos mal posicionados, liberando assim recursos que poderão ser reorientados em direção ao segmento de atividade mais valorizado, mas onde se pode melhorar a posição concorrencial. Em certas situações extremas, onde há o risco de ser definitivamente ultrapassado em relação a este último segmento, por falta de uma reação mais rápida, será necessário investir sem esperar os efeitos da transferência. Neste caso, é necessário ser extremamente vigilante a fim de que a transferência se faça o mais rápido possível e que os recursos liberados possam ser reorientados em direção a outros domínios. Caso contrário, a longo prazo, poderá haver uma captação de recursos indevida, que prejudica as atividades que poderiam se beneficiar desses recursos.

O porta-fólio número 3 é um porta-fólio ao mesmo tempo mais arriscado e menos adaptado, que denota um fraco domínio do setor considerado. Necessita, antes de tudo, de uma análise precisa da concorrência, já que o encontramos freqüentemente nos domínios de atividade que estão submetidas a uma evolução científica e/ou técnica que abre novas perspectivas. Neste caso, será 
necessário antes de tudo voltar a atenção sobre os dois segmentos mais valorizados, a fim de definir as estratégias que permitirão fazer progredir sua posição estratégica. É necessário por vezes se desembaraçar o mais rapidamente possível dos segmentos de fraco valor. Entretanto, o tempo do processo de desengajamento dependerá de uma aceitação psicológica por parte dos profissionais ligada à evolução dos segmentos de alto valor.

O porta-fólio número 4 aparece como mais promissor e equilibrado, pois os segmentos menos importantes (em volume de atividade) não estão bem posicionados em termos de valor. Denota um forte controle do domínio considerado. As preocupações são, neste caso, de duas ordens: de um lado, controlar as manobras da concorrência para evitar surpresas desagradáveis e evitar a super alocação de recursos decorrente da influencia interna que poderão adquirir os responsáveis pelo domínio em questão.

Estes quatro exemplos mostram que, nos casos extremos, é necessário, antes de tudo, preocupar-se com os concorrentes e com o meio ambiente, descobrir as oportunidades e ameaças e, que convém, antes de tudo, em certos casos, analisar com detalhe o conteúdo das atividades, a partir dos pontos fortes e fracos identificados.

Da leitura dos porta-fólios, podemos depreender que os segmentos prioritários são os de alto valor. Em geral, deveriam ser estimulados os segmentos de alto valor. Porém, nem sempre um segmento de baixo valor é sinônimo de abandono do mesmo (especialmente quando o volume de atividade é grande e a atividade não é realizada por outros). Por outro lado, quando os segmentos apresentam uma baixa capacidade competitiva, mas alto valor, significa que a melhor estratégia seria a de investir na melhoria da posição competitiva, aumentando o rendimento e o controle dos fatores-chave de sucesso. O ideal é encontrar os segmentos à direita do porta-fólio. Porém, o porta-fólio não deve inspirar movimentos de forma mecânica: ele é um documento para ajudar a pensar uma estratégia.

O porta-fólio serve para determinar prioridades, para fixar a estratégia do hospital em termos de três possibilidades de objetivos, principalmente:

- Desenvolver um segmento: identificar as atividades que deve ser expandidas, priorizadas, desenvolvidas particularmente. Este objetivo em geral se confunde com a estratégia de diferenciação ou de agregação de um plus de valor percebido como melhora de qualidade, podendo implicar mais custos, em investimentos específicos para enfrentar os pontos fracos típicos dos FCS. O desafio aqui seria buscar a estratégia de diferenciação que envolvesse relativamente menos custos.

- Manter ou estabilizar um segmento: definir os segmentos a manter em "banho-maria", no mesmo nível de desenvolvimento histórico, se possível re- 
duzindo custos. Aqui podem constar segmentos de alta competitividade e valor, os quais poderiam ser apenas mantidos na atual posição, reduzindo custos e liberando recursos para outras atividades.

- Reduzir o recrutamento da clientela para um segmento: definir os quais seria necessário recortar ou focalizar, desestimular, diminuir, negociando a transferência parcial ou total de atividades para a rede (entende-se por focalização privilegiar um determinado tipo de usuário ou nosologia).

Para Porter (1982), haveria três estratégias genéricas, mais bem discutidas adiante a partir da obra de Crémadez \& Grateau, 1997: diferenciação, que implicaria definir uma oferta única, exclusiva, diferenciada, percebida por todos como superior qualitativamente, cujo acesso também poderia ser diferenciado; liderança no custo, que representaria diminuir custos para liberar recursos para outros segmentos, sem comprometer a qualidade; focalização (que pode evoluir como estratégia de custos e/ ou diferenciação).

\section{Elaboração dos planos de ação}

Os planos incluem os esforços a realizar para agir sobre a rede de médicos de consultório (que referem pacientes), para implementar associações, para formar médicos e pessoal paramédico, para comunicar o savoir-faire controlado, para adquirir novas tecnologias, para implementar novos modos de atenção etc.

O Plano de Ação é o 'que fazer' para implementar a Estratégia. Consistiria em um conjunto de atividades, tais como:

- Formas de apropriação/desenvolvimento dos FCS visando a enfrentar os pontos fracos identificados na análise incorporação de tecnologias e de recursos humanos, treinamentos, desenvolvimento de fatores de qualidade etc.

- Ações de negociação e de comunicação internas ao hospital e com a rede, incluindo o estabelecimento de sinergias e parcerias externas.

- Ações visando a revalorizar um segmento, atuar sobre algum critério da análise do valor de baixo score, passível de intervenção (quando a decisão política é de buscar aumentar o valor).

- Ações visando a modificar o modelo assistencial, as formas de atendimento que caracterizam um determinado segmento e o perfil de tecnologias utilizadas.

- Ações de natureza social e intersetorial.

- Ações que desenvolvam objetivos tipicamente médicos, como determinadas pesquisas. 
A consolidação de um plano de ação é um contínuo retomar da análise estratégica do valor e da posição competitiva, com o objetivo de aumentar o controle dos FCS, para melhorar a posição estratégica geral. O plano culmina com a definição dos indicadores de monitoramento das ações para que seja possível acompanhar as mudanças propostas.

\section{Avaliação das dificuldades encontradas}

Esta avaliação apóia-se, principalmente, em dados colhidos na Unidade de Análise Estratégica do Centro Hospitalar de Lille, nos encontros mantidos durante nossa visita àquele complexo hospitalar, em encontros que aconteceram no Brasil, quando da vinda de Monsieur Le Ludec, ${ }^{2}$ em documentos citados que fazem parte do material instrutivo do enfoque e, em parte, em uma análise ainda parcial de algumas experiências brasileiras.

Entre as dificuldades gerais, destacam-se: o ceticismo, a descrença na mudança, as barreiras de linguagem, a desconfiança, a indiferença e a recusa a comprometer-se.

Em relação ao diagnóstico, as maiores dificuldades residem na ausência de sistemas de informação ao início da démarche, na opacidade da atividade da concorrência, na seleção da informação qualitativa, na debilidade da base documental e na pobreza dos dados epidemiológicos e/ou na dificuldade de sistematizá-los.

$\mathrm{Na}$ fase da segmentação, alguns problemas se tornam evidentes:

- a segmentação é um conceito difícil de se apreender: o grupo médico tende a confundir segmento e grupo homogêneo de doença, em circunstâncias que a segmentação das práticas de trabalho pode obedecer a outros critérios (como o tecnológico, o gerencial e o populacional), para além do critério entidade epidemiológica. Isto gera algumas reticências por parte dos profissionais;

- a linguagem utilizada não pertence ao vocabulário médico;

- há uma tendência para definir uma segmentação "territorial", reflexo de uma luta pelo poder ou reveladora de problemas latentes.

Sobre a fase da análise estratégica, detectaram-se outros problemas:

- a lógica das grades não é facilmente percebida, há uma interrogação múltipla sobre a utilidade da ponderação e da notação;

Monsieur Le Ludec é um dos responsáveis pelo desenvolvimento da demarche stratégique em Lille, tendo acompanhado a experiência por nove anos. 
- a notação é considerada definitiva quando se examinam todos os segmentos;

- os comentários devem ser objeto de um consenso absoluto, o que torna a formalização cansativa;

- os serviços em posição de monopólio se prestam menos a este tipo de análise;

- surge a necessidade da busca de informações adicionais e, muitas vezes, existe dificuldade na obtenção dos dados.

O processo de elaboração dos planos, finalmente, enfrenta algumas dificuldades:

- os objetivos são às vezes pouco ou mal definidos por falta de comprometimento;

- $\quad$ ausência de participação de profissionais não médicos do hospital;

- planos de ação de natureza essencialmente médica, sem ligação com um projeto social;

- indicadores às vezes difíceis de pôr em prática.

\section{Análise crítica geral}

Em primeiro lugar, um dos maiores méritos da démarche é ensejar a definição de objetivos médicos e desenvolvimento de um processo de a avaliação das atividades institucionais e da missão organizacional. O grande objetivo da busca da articulação gerencial de um projeto médico é, em grande medida, cumprido. Durante a nossa visita à Unidade de Análise Estratégica do CHRU, pudemos levantar e revisar os Projetos de Estabelecimento concluídos ao longo de quatro anos de aplicação exaustiva da démarche. Praticamente todos os serviços dos vários hospitais desta verdadeira holding hospitalar foram envolvidos nesta lógica gerencial. Os estágios de desenvolvimento do projeto da démarche variam de serviço a serviço. Porém, esta nova racionalidade gerencial já é uma realidade, reconhecida na França como um dos modelos de gestão respeitados.

A aplicação da démarche não é um processo apenas formal, que se resume à documentação pertinente aos projetos de estabelecimento centralizados na Unidade de Análise Estratégica. Sua lógica de implementação, baseada em reuniões colegiadas, insere-se no objetivo de motivar uma comunicação ampla a serviço de uma mudança cultural. O desafio implícito é articular um coletivo em torno de um projeto único, que considere a rede. Os resultados da démarche medem-se ao longo do tempo, em um processo interativo, sempre exploratório, capaz de impactos culturais decisivos. Isto não é uma tarefa simples, assimilável à condição de uma gestão racionalizadora ou estabilizadora, de efeitos imediatos. Trata-se 
de construir a colaboração, através, principalmente, de novas parcerias, do aprofundamento de sinergias internas e de uma nova postura, mais comunicativa entre os diferentes profissionais/atores.

A Coordenação da Unidade de Análise Estratégica garante, no entanto, a existência de resultados palpáveis, que constam de trabalhos em vias de publicação, a que tivemos acesso durante a visita. Estes trabalhos, como o de Thomas Le-Ludec (1995), acentuam em geral a montagem de estruturas transversais de colaboração entre hospitais, especialidades e segmentos. A produção de resultados instrumentais, situados na lógica da otimização da alocação de recursos e da colaboração com a rede, é, sem dúvida, uma necessidade prática, premente, de caráter legitimador.

Problematizemos um pouco mais o enfoque. Uma das principais restrições à démarche, surgida nas nossas discussões, refere-se à eventualidade da segmentação estratégica reforçar a atomização, ao invés de ajudar a integração (por ser muito molecular). Esta crítica é bastante séria e merece uma discussão. Existe a possibilidade de que a segmentação se paute pela especialização do conhecimento médico e pela disputa de territórios. Por outro lado, deve considerar-se que a aplicação geral do enfoque é feita serviço por serviço, disciplina por disciplina. Que a análise estratégica dos segmentos é um trabalho feito no nível de pequenos grupos. Surgem perguntas naturais do tipo: como promover a agregação, a coordenação horizontal, a fim de garantir um projeto integrado, prioridades únicas por estabelecimento? Como compensar a tendência à diferenciação implícita em uma segmentação muito molecular?

$\mathrm{Na}$ realidade, este problema se coloca para fora da especialidade, pois considerando a especialidade em si, uma segmentação bem feita forneceria as bases técnicas necessárias para uma análise de prioridades que permitiria chegar pela via da discussão crítica e democrática a um consenso de especialidade. Um bom detalhamento dos grupos homogêneos de atividades ajudaria a estabelecer uma dinâmica de avaliação voltada para a caracterização da posição estratégica diferencial dos mesmos grupos. Não se é bom em tudo. Há áreas de excelência e de não excelência. A não diferenciação de atividades poderia ocultar particularidades e defasagens em posição estratégica dificultando o processo de priorização de atividades. Por outro lado, uma segmentação baseada em um diagnóstico médico rico e na tentativa de agrupar atividades homogêneas a partir da conjugação de vários critérios técnicos e sociais, pode ajudar a desmontar feudos montados a partir do exercício do poder e da informalidade.

A questão se refere ao aspecto interespecialidades. Com base nas conversações que mantivemos na UAS, podemos assinalar que a necessidade e a possibilidade da integração dependem de uma dinâmica que obriga a agregar e desagregar iterativamente os grupos de trabalho e a procurar instâncias de discussão mais abrangentes, que superem o microcosmo do segmento, da disciplina e até 
do hospital. Um dos grandes desafios do método está relacionado à existência de fóruns ampliados de agregação de interesses, onde se processe o grande acordo ou a grande negociação do projeto hospitalar, imanente à lógica da démarche.

É importante frisar que se, de um lado, a segmentação pode ser considerada um fator de diferenciação, não é menos verdadeiro, por outro lado, que é a partir da categoria celular de segmento que a démarche procura 'costurar' a idéia de uma rede integrada de oferta de cuidados. Uma das preocupações mais marcantes do plano de ação consiste deliberadamente em destacar as sinergias e parcerias potenciais inerentes a cada segmento, para a partir daí explorar possibilidades de estruturas em rede. Não se deve esquecer que um dos objetivos nucleares do enfoque é justamente o de criar um movimento de transformação do hospital em uma organização aberta. Detectar os pontos de sinergia e de complementaridade é a base para a formulação de lugares organizativos de discussão mais ampliada. Finalmente, devemos reforçar a idéia de que a segmentação pode obedecer a critérios mais integradores como tipo de atendimento ou população, para além de uma divisão baseada na diversidade de patologias ou tecnologias. Desta maneira, procuramos sustentar o argumento de que a segmentação estratégica é a base de um processo contraditório de diferenciação e de integração, em que a busca da complementaridade e da colaboração é um dos requisitos essenciais, a ser garantido por um tipo de metodologia política de negociação que implique o desenvolvimento de discussões transversais e da montagem de estruturas em rede.

Uma das maiores dificuldades está relacionada à difícil aplicação da démarche em situações de monopólio. Parece-nos que a démarche francesa supõe um contexto de menor restrição de recursos e de competição, o que nem sempre acontece nos países em vias de desenvolvimento. Pode-se argumentar que em alguns espaços desses países vigoram essas condições de contexto, mas não em todos. Esta situação não invalida o enfoque, apenas o restringe em sua aplicação. Mesmo em uma situação de concorrência precária ou inexistente, a simulação da concorrência que pode virtualmente passar a existir ajuda a estabelecer estratégias para aprimorar o domínio dos fatores-chave de sucesso das atividades.

De qualquer maneira, a perspectiva de aplicação do enfoque dependeria de simplificações e adaptações ao nosso contexto. Vamos referir-nos, em geral, às principais reformulações necessárias, de acordo com as discussões preliminares desenvolvidas no nosso âmbito.

Tudo indica que uma adaptação dos critérios envolvidos na determinação da capacidade de atração se faz necessária. Na realidade, a relação de critérios e o seu peso específico são variáveis, ajustáveis no método, em função das características do mercado de serviços de saúde em pauta, em cada momento. Nesta medida, a idéia de se trabalhar com um elenco menor de variáveis representati- 
vas, cuidadosamente escolhidas, é algo absolutamente normal, tendo em vista o contexto local e as possibilidades de manuseio da metodologia.

Outro aspecto que pode ser objeto de adaptações refere-se à definição de objetivos. O método original não enfatiza a criação, pelo menos explicitamente, de novos segmentos como parte das principais estratégias, embora esta possibilidade esteja incluída na abordagem francesa. Dada a necessidade eventual de se abrirem novos serviços, em função de carências sanitárias, situação comum em países com poucos recursos, a estratégia deveria acrescentar, às três dimensões de objetivo do enfoque (desenvolver, estabilizar, reduzir), a meta da criação de novas atividades.

Nesta linha de raciocínio, consideramos necessário reforçar os critérios populacionais e epidemiológicos, para contrabalançar as características da démarche relacionadas a um modelo típico de planejamento baseado na oferta. Esses critérios ligados à detecção de necessidades de saúde deveriam ser levados em conta de maneira mais explícita na análise da possibilidade de abertura de novos grupos de atividades e na análise do valor dos grupos de atividades (re)organizados valendo-se da estrutura da oferta preexistente. Devemos acrescentar, porém, para fazer justiça ao método, que o dado epidemiológico está embutido no critério possibilidades de crescimento ou desenvolvimento dos segmentos como parte da análise do valor estratégico dos mesmos ou de seu nível de prioridade relativo.

Com estas considerações gerais, concluímos aqui nossa apresentação panorâmica do método de planejamento da démarche, não sem antes afirmar que vemos este enfoque como um modelo de gestão estratégica e comunicativa da realidade hospitalar com enormes possibilidades práticas, como pudemos constatar na nossa experiência de aplicação no Brasil, que não é desprezível.

\section{A Conquista de Vantagens Concorrenciais: estratégias genéricas}

Dispõe-se de uma vantagem determinante sobre seus concorrentes quando se detém a primazia de uma competência fundamental para se ter êxito em um segmento de atividade. A vantagem concorrencial se fundamenta no fato que os usuários (pacientes, quem referencia...) reconhecem à oferta de um concorrente um acréscimo de valor suficiente para que prefiram a ele recorrer. Este diferencial de valor se resume em geral a uma relação qualidade/preço. Em circunstâncias em que a realidade de preços não impera, pode-se apreciar o valor concedido a um serviço pelos esforços feitos para pela clientela para ter acesso a ele (deslocamento, espera consentida...). 
Podem-se seguir duas vias estratégicas gerais para aumentar a base de vantagens concorrenciais disponível: aumentar o valor para o usuário ou envolver menos recursos sem diminuir o valor do serviço, tal como percebido pelo usuário em termos de qualidade.

A estratégia de diferenciação acentua o valor. Esta via supõe a possibilidade de criarmos um acréscimo de valor superior ao custo suplementar envolvido para esse fim. A via dos ganhos em eficiência, em troca, supõe que sejamos capazes de racionalizar a produção de tal maneira a não afetar a qualidade e a que esta racionalização gere um ganho de recursos suficiente para que sua realocação produza uma vantagem estratégica dominante.

Para detectar as fontes de vantagens concorrenciais, seria necessária uma visão analítica dos processos de criação de valor no interior de uma empresa e de suas interações, isto é, analisar sua cadeia de valor e a estrutura de custos correspondente. $\mathrm{O}$ termo cadeia de valor (oriundo de M. Porter) corresponde à descrição das atividades que a organização implementa para realizar e colocar à disposição dos clientes seus produtos ou serviços.

Haveria vários tipos de atividades:

- A gerência e o conjunto de atividades estruturantes, incluindo a negociação com os financiadores e os fornecedores, a organização de atividades, a gestão de recursos humanos, o financiamento do investimento, os estudos de mercado, as escolhas tecnológicas e de tipo de serviços etc.

- As atividades de suporte operacional: considera-se atividade de suporte operacional toda atividade logística que não corresponde a um fator chave de sucesso para determinado segmento da atividade, mas que é necessária para a realização da prestação de serviço. Em geral, esta atividade corresponde à logística não médica, passível de ser terceirizada porque não corresponde a um savoir-faire determinante no jogo concorrencial .

- As atividades operacionais principais: todas aquelas que concorrem principal e diretamente para a realização do serviço. Podem ser mais ou menos específicas de um segmento ou ser compartilhadas entre vários, como é o caso da estrutura tecnológica relativa aos setores de imagem e de biologia, por exemplo. Estas tecnologias se organizam em torno de processos de atendimento mais ou menos formalizados, precisos e controlados. A concepção e a condução destes processos deveriam estar no centro da reflexão sobre ganhos em eficiência e em valor. Esta dimensão depende totalmente da experiência dos profissionais (médicos e para médicos) e não costuma ser objeto de intercâmbio de experiências. É nesses processos de atendimento que as práticas rotineiras dominam e são raramente questionadas de maneira regular e organizada. Porém, são causas habituais de acréscimos no custo: redundância de exames, exames inúteis e custosos, entre outros. 
Os diferentes componentes de uma cadeia de valor não são independentes. Há conexões entre os vários componentes da cadeia de valor de um mesmo segmento e entre componentes de segmentos diversos. Estes componentes também apresentam interfaces com componentes da cadeia de valor de outras instituições com as quais a organização mantém relações de referência de pacientes, de fornecimento e compra de produtos ou de intercâmbio científico.

As vantagens concorrenciais seriam obtidas através da intervenção nestas interfaces como trabalhando no nível de cada componente gerador de valor. A exploração das interfaces é uma fonte importante de vantagens, que subentende a existência de um bom sistema de comunicação/acompanhamento. Crémadez inclui a logística médica e a comunicação informatizada como atividades operacionais principais justamente por este motivo.

Há inúmeros exemplos de exploração das interfaces: a saída de um serviço clínico e a entrada em outro; a relação emergência-serviços para o encaminhamento dos pacientes e a coerência de seu tratamento; a interface medicina-cirurgia em algumas patologias e atos, como a cancerologia, as hérnias de disco, a insuficiência coronariana, os transplantes etc. e as relações de referência e contra-referência de pacientes com a rede.

O conhecimento da estrutura de custos dos segmentos é de fundamental importância para a definição de estratégias de obtenção de vantagens. A estrutura de custos de uma atividade caracteriza-se, de maneira sintética, pela proporção de custos fixos de origem central, de custos fixos específicos e de custos variáveis. Os custos fixos mais importantes das atividades hospitalares correspondem à infra-estrutura de internação/alojamento, ao pessoal e às tecnologias implementadas.

Quando a estrutura de custos de uma atividade revela uma preponderância dos custos fixos alocados sobre os custos fixos específicos e os custos variáveis, seria interessante optar pela busca de vantagens estratégicas pelos custos. Quando se revela uma preponderância do custo variável unitário direto e de custos fixos específicos em relação aos custos fixos centrais alocados, seria necessário pensar em termos de diferenciação. A diversidade de atividades de um estabelecimento leva a adotar um mix de estratégias genéricas.

Em outras palavras e segundo nossa interpretação, a estratégia de custos, em geral, seria justificada principalmente, quando os segmentos dependem de tecnologias e de infraestrutura de internação custosas e compartilhadas (que não representam custos fixos específicos). Isto porque seria necessário considerar estes recursos e minimizar a disputa de maneira a garantir recursos para todos, o que demandaria uma racionalização, como, por exemplo, controlar o tempo de permanência, baixando custos. A não ser que o segmento apresente forte potencial de diferenciação, o fato de não contar com recursos próprios (ou 
potencial de captação destes recursos) que gerem custos fixos, como tecnologias, sugere que a estratégia de diferenciação não seria a melhor opção. Neste caso, o investimento necessário em capacidade instalada, tecnologias e recursos humanos especializados representaria relativamente uma nota menor, devido ao baixo controle, diminuindo o score resultante da análise de valor do segmento. $\mathrm{O}$ investimento ainda por ser realizado dificultaria a obtenção de vantagens comparativas via diferenciação.

\section{A estratégia fundada nos custos}

É indispensável conceber uma estratégia de custos em todos os segmentos de atividade que precisam de infra-estruturas caras e compartilhadas, que apresentam um custo variável unitário pouco elevado e reduzidas formas de se diferenciarem expressivamente dos concorrentes.

Genericamente, a estratégia de custos consiste em privilegiar atividades que reforcem o potencial de sinergia já existente - atividades para as quais o controle dos custos compartilhados é um savoir-faire determinante -, bem como em eliminar custos específicos não justificados para garantir a conexão mais eficaz entre cadeias de valor.

O controle do custo operacional dos recursos humanos supõe investimentos em formação e em organização. Para o pessoal paramédico, recomenda-se uma formação polivalente e/ou a criação de grupos polivalentes que permita uma maior flexibilidade na sua distribuição pela organização, garantindo um forte grau de aderência a cada serviço específico para onde foram destinados (uma posição intermediária entre a gestão global ou centralizada do corpo de profissionais e uma destinação rígida no interior de um). Para o pessoal médico, recomenda-se uma formação que fomente uma visão multidisciplinar, assim como o estabelecimento permanente de contatos visando à formulação de consensos sobre as práticas profissionais.

Os custos de infra-estrutura são sensíveis à taxa de ocupação e de rotatividade, por um lado, e à adequação dos pacientes à vocação da estrutura, por outro.

Em uma estratégia de custos, seria necessário maximizar a taxa de ocupação, o que dependeria, em boa medida, de estruturas menos rígidas, mais flexíveis, que se adaptem às evoluções do mercado, ao rendimento e à própria evolução da missão da organização.

A rotatividade está ligada ao tempo de permanência dos pacientes. Para reduzir custos, seria necessário combater alguns procedimentos relacionados à entrada e à saída de pacientes e privilegiar estruturas de atendimento especializa- 
do, programado e de duração determinada, que explorem as sinergias entre atividades.

É conveniente, ainda, regular as relações entre as estruturas técnicas de apoio diagnóstico e terapêutico e os serviços clínicos, levar em conta os pontos de estrangulamento não superáveis a curto prazo e recorrer eventualmente aos meios de parceiros externos.

A adequação depende do grau de correspondência entre o tipo de clientela e a especialização da estrutura. A inadequação é fonte de desperdício de recursos e resulta, em boa medida, de serviços de triagem e de orientação que funcionam mal.

O controle do fluxo de pacientes é um elemento fundamental da redução de custos. Uma boa comunicação com os serviços que referenciam pacientes e com aqueles que complementam um cuidado é fator chave dessa estratégia.

\section{Os custos tecnológicos}

O controle destes custos depende da oportunidade de aquisição de equipamentos a preços estáveis, conhecidos e que favoreçam um prazo de recuperação curto dos investimentos. Devem-se avaliar os riscos no caso de superposição de equipamentos nos diferentes concorrentes e evitar equipamentos ociosos ou semi-ociosos.

Em segundo lugar, é necessário considerar a concentração de equipamentos como fator de economias de escala e seu compartilhamento quando isto é necessário para atingir a massa crítica de atividade correspondente ao limiar de rentabilidade.

O controle da aprendizagem da apropriação das tecnologias é fundamental. Todas as fases envolvidas na implementação de uma tecnologia, para além da mera manipulação, devem ser objeto de um treinamento que envolva um conjunto diversificado de pessoas, de modo a não ficar restrito ao operador. Este processo deve envolver também o controle e a gestão do processo de substituição tecnologias.

Os ritmos de utilização dos equipamentos, a fim de evitar os custos adicionais decorrentes de flutuações (super ou subutilização), é outro importante fator no controle de custos tecnológicos, que depende de um bom controle da demanda e dos fluxos de chegada.

Um elemento fundamental numa estratégia fundada nos custos é a pesquisa de inovações tecnológicas capazes de diminuir o tamanho da infra-estrutura necessária e/ou de gerar uma substituição tecnológica que permita uma maior 
programação do atendimento, um controle crescente dos prazos de tratamento e uma tendência para formas de tratamento que impliquem tempos de internação mais reduzidos (tecnologias para cirurgias menos invasivas, por exemplo).

\section{Os custos variáveis}

Representam uma fração menor do conjunto de recursos alocados em um estabelecimento hospitalar, mas a margem de liberdade depende em grande parte de seu controle.

A redução de custos variáveis depende de duas alavancas fundamentais:

- A gestão do abastecimento e de estoques que repousa no desenvolvimento de competências específicas.

A capacidade de negociação representa um fator importante de redução dos custos de abastecimento que não é implementado devidamente. Baseia-se na seleção, conhecimento do mercado, prática da concorrência , utilização dos efeitos de tamanho e de escala nas compras. Já a competência em explorar a sensibilidade da estrutura de custos dos fornecedores ao comportamento do cliente: estabilidade das especificações, prazos de pagamento, regularidade e volume dos pedidos unitários, etc. são fatores de redução dos custos dos fornecedores dos quais podemos tirar partido nas negociações. A terceira competência específica é o rigor na definição das especificações dos produtos comprados e, principalmente, na definição de seu acondicionamento unitário em função das práticas de consumo (evitando o desperdício devido a acondicionamentos não adaptados, por exemplo).

- A formalização das práticas de atendimento e sua análise crítica regular

A implementação de rotinas profissionais pela formalização é indispensável para controlar os custos variáveis, pois a formalização atuaria positivamente, em termos de eficiência, sobre os três componentes fundamentais dos custos variáveis: o consumo de atos, de produtos farmacêuticos e de material de consumo.

\section{Estratégias de diferenciação}

A diferenciação, em geral, confunde-se com o desenvolvimento de uma competência médica específica, associada, em certos casos, ao controle de certas tecnologias. Esta é a via de diferenciação mais comum historicamente. Mas não é e não deveria ser a única.

A diferenciação pode operar modificando um ou vários elementos da cadeia de valor, explorando as relações entre os elementos das cadeias de valor de 
dois segmentos que apresentam sinergias potenciais e modificando a conexão e a coordenação com os parceiros externos. Todos estes elementos podem desempenhar um papel determinante na satisfação global do cliente.

\section{Modificação da cadeia de valor de um segmento}

Esta estratégia pode consistir em introduzir um serviço complementar na cadeia de valor de um segmento: desenvolvimento de cuidados paliativos no tratamento do câncer; aumento do número de formas de preparação do parto em obstetrícia. Pode significar, também, completar ou modificar apenas um componente da cadeia de valor: a passagem de um "serviço-porta de entrada" (triagem) para a admissão direta pode ser uma via de diferenciação que questiona os elementos acesso, acolhimento, comunicação clientes-sistema de referência da cadeia de valor de vários serviços. É o complemento normal da especialização dos serviços clínicos. Com efeito, a especialização tem pouco impacto, se não acompanhada de uma ampliação das relações com o sistema de referência que permita o recurso direto.

Pode-se compensar a perda de flexibilidade induzida pela especialização pela criação de estruturas intermediárias concebidas para responder às necessidades dos pacientes fora da etapa aguda e para economizar recursos raros e custosos (o compartilhamento destas estruturas entre serviços é extremamente necessário e ainda pouco experimentado). Uma maior colaboração com os parceiros externos pode evitar alongamentos indevidos das internações.

\section{Modificação da conexão e coordenação entre dois segmentos que apresentam sinergias}

Corresponde a remodelar as relações entre dois segmentos com a finalidade de explorar novas sinergias: estreitar os laços entre os médicos especializados e a cirurgia em torno da problemática dos transplantes ou entre a pediatria e a obstetrícia para oferecer um serviço mais completo para as futuras mães, gerando efeitos positivos no sentido do recurso posterior a este hospital no que concerne ao acompanhamento dos filhos.

\section{Modificação da conexão e da coordenação com parceiros externos}

Significa o estabelecimento de parcerias visando a suprir carências de equipamentos, desenvolver pesquisa clínica, participar do ensino universitário ou de 
pós-graduação, diminuir o tempo de permanência e a beneficiar-se da transferência de tecnologia etc.

Como a diferenciação pode implicar em mais custos o grande desafio que enfrenta esta estratégia é a escolha de formas de diferenciação relativamente menos custosas, em que o ganho em valor ou qualidade do serviço prestado supere os acréscimos em custo.

A estas duas estratégias genéricas deveríamos acrescentar uma terceira, já indicada anteriormente, a Focalização, que consistiria em recortar um segmento ou em privilegiar dentro do mesmo uma determinada categoria de usuário, de nosologia clínica ou de tipo de tecnologia de atendimento. Por exemplo, restringir o ambulatório de adultos de um determinado hospital psiquiátrico à população adscrita a uma área programática menor ou às patologias de maior complexidade. Ou ainda, privilegiar dentro do mesmo um tipo de atendimento aquele mais programável, referenciado (paciente ligado a uma determinada equipe), de natureza multidisciplinar.

\section{O Hospital como Estrutura em Rede}

Como já foi bastante salientado, um dos objetivos estratégicos do enfoque em pauta é o estabelecimento de redes de cooperação interna e externa, e um tipo de estrutura organizacional coerente com essa perspectiva.

Crémadez e Grateau (1992) reconhecem a possibilidade de quatro tipos de cooperação eventual. Neste sentido recriam, para o contexto sanitário, as formas de aliança estratégica definidas no texto sobre Política Geral de Empresa: Stratégie, Structure, Décision, Identité, do grupo Strategor (1997). Estes tipos são:

- Parceria vertical: corresponde a coordenar os papéis dos estabelecimentos no seio de um mesmo processo de prestação de cuidados. Por exemplo, integração entre os níveis primário, secundário e terciário de um determinado domínio de atividade (implantação de um sistema de referência e contra-referência materno-infantil).

- Integração Conjunta: corresponde ao compartilhamento de uma tecnologia, especialmente de recursos raros (diagnóstico e terapia). Aqui, sem se acabar completamente com a concorrência virtualmente existente, congela-se um elemento.

- Adicionamento ou acréscimo: neste caso, não há mais concorrência. Articulam-se estabelecimentos ou unidades em torno de serviços completos. Há a constituição de um potencial comum. Por exemplo: organi- 
zação de pesquisa multicêntrica. Neste caso, a concorrência virtual cede o lugar à competição interna.

- Complementaridade: consiste na valorização das contribuições complementares, na geração de uma prática diferenciada útil para todos os cooperantes. Exemplo: cooperação entre redes de cuidados, entre a medicina e a geriatria, substituindo a concorrência pela cooperação.

É importante resgatar a idéia de que o processo de integração estratégica do enfoque em questão não se coaduna com uma visão monolítica da saúde pública, representada pela proposta de um único modelo de integração incutido pela regulação central, considerado um modelo de otimização. A rede deve ser vista como o resultado da imbricação das oportunidades de diferentes formas de cooperação de que se oferecem aos atores que compõem um sistema. É um conceito que repousa sobre a capacidade de negociação e contratualização dos atores, já referida. O papel da regulação seria o de incitar, ativar e coordenar este processo de aproximação e de relacionamento, respeitando a diversidade. Neste particular, a via da responsabilização dos atores nada tem a ver com um tipo pesado de planificação tecnocrática (Rivera, 1998).

A respeito do postulado da organização em rede interna, é necessário assinalar que, em nossos dias, o paradigma predominante deveria ser o da flexibilidade e adaptabilidade organizacional. Postulam-se estruturas planas, com um número mínimo de níveis hierárquicos e unidades de pequeno tamanho e grande latitude de ação. Este ideal organizacional já é uma realidade no ambiente hospitalar. O grande problema hospitalar é, porém, a falta de integração ou a diferenciação exagerada, que deve ser compensada.

A estrutura em rede interna, vista como alternativa à diferenciação desmedida, é definida como a organização das relações entre indivíduos multipertencentes, que assumem papéis flexíveis em processos de integração, suscetíveis de valorizar o potencial de riqueza e de inovação ligado a uma diferenciação incitada ou estimulada.

A estrutura pertinente possibilita aumentar a iniciativa e a inovação, cria a possibilidade de novos serviços que podem significar uma vantagem competitiva, e permite a reunião de dimensões estratégicas interdependentes e de importância equivalente (sem hierarquia).

As principais características de uma organização em rede interna seriam, para Crémadez \& Grateau (1997), as seguintes:

- A dinâmica organizacional supera (ou prevalece sobre) as formas estruturais.

- Um profissional pode ser responsável por uma dimensão da organização e subordinado ao responsável de uma outra dimensão. Esta estrutura estimula a capacidade de liderança da organização. 
- A missão da liderança formal seria mobilizar o potencial de iniciativa da organização a serviço de uma perspectiva estratégica.

- O dirigente deve se preocupar com a adesão dos atores aos eixos de colaboração. A desierarquização da participação nas instâncias de integração é um imperativo.

- Em uma estrutura em rede, a estratégia e as opções em geral são elaboradas em conjunto, em uma perspectiva global.

- O Poder se fundamenta na capacidade de fazer chegar a informação aos indivíduos que estão melhor localizados para utilizá-la, sem retê-la.

- A solidariedade predomina, o desempenho é coletivo.

- Os processos são de auto-organização.

- Não se deve descurar da ambiência externa, que é o perigo implícito na excessiva preocupação com as relações internas.

Uma Rede estaria composta por pólos (nós da rede) que combinam as unidades de base em função de conexões que visam a obter a integração desejada. Estas conexões podem corresponder estruturalmente a comitês permanentes ou temporários ou a departamentos e podem se dar em vários planos: conexões econômicas, burocráticas, operacionais, culturais etc., várias dimensões podem estar presentes simultaneamente.

Em relação ao poder de ativação, de criação de novos intercâmbios, de novas conexões, defende-se um modo de ativação controlada: grande efervescência na base, limitada por processos de seleção de iniciativas na cúpula.

O conjunto do dispositivo estaria baseado no principio da auto-organização das relações entre as unidades, que se desenvolve nos pólos de integração, e da auto-organização das unidades de base, correspondendo a um modelo de descentralização, que é mais amplo na medida em que as unidades são de pequeno tamanho e que a organização é plana, achatada. A capacidade de representação nas estruturas de integração estaria baseada na competência relacionada à problemática tratada e não na linha hierárquica (na chefia tradicional).

O enfoque sugere a possibilidade de vários critérios de definição de eixos transversais: população (idosos, mãe-filho...), conjunto de patologias (cancerologia, endocrinologia), campo anatômico (visceral, neurológico), implementação de tecnologias mais ou menos sofisticadas (cirurgia, transplantes).

Em relação a este último aspecto, algumas técnicas permitiriam uma estrutura de tratamento multidisciplinar, como por exemplo (Le Ludec, 1995a apud Rivera, 1998): reagrupamento em torno das técnicas laser de gastroenterologistas, dermatologistas, ginecologistas e cirurgiões; reagrupamento de fisiologistas, radiologistas e neurologistas em torno da ecografia vascular; reunião em torno 
da cirurgia anti-arrítmica de cardiologistas, cirurgiões cardiovasculares, engenheiros biomédicos.

Trata-se, portanto, de mobilizar as sinergias ao redor de aproximações multidisciplinares, da problemática das emergências, dos idosos etc. Ou seja, de superar a rígida atomização entre as unidades de base correspondentes às tradicionais especialidades médicas, procurando articulá-las a partir dos critérios anteriores, considerados em um sentido abrangente. Particular importância concede-se, ainda, ao critério gerencial: tipo de atendimento neste processo de desatomização.

O objetivo central da estrutura em rede é desenvolver redes de reflexão estratégica. As conexões variam. Algumas são importantes estrategicamente, mas não geram ligações operacionais pesadas e contínuas.

Quando o campo transversal das relações aumenta (muitas unidades de base contempladas), a densidade das relações operacionais diminui, o que enseja uma centralização vertical na dimensão estratégica e uma descentralização horizontal importante. Isto corresponde a um contexto organizacional em que várias unidades seguem diretrizes estratégicas comuns com grande autonomia operacional.

$\mathrm{Na}$ busca pela transversalidade, o enfoque faz justiça ao critério gerencial como potencial fator de integração ou de reunião da diversidade. Sustenta-se a necessidade de explorar as formas ou modos de atendimento (ambulatório, hospital-dia, emergências etc.) como lugares possíveis de negociação interdisciplinar. Esta forma de gerenciamento defende a necessidade de normalizar os modos de atendimento para organizar a diversidade, como veremos adiante. Esta normalização implicaria a definição comunicativa das características dos processos de trabalho respectivos e de suas condições de sucesso ou, dito de outro modo, no estabelecimento de diálogos internos voltados para a geração de acordos sobre estas variáveis das formas de atendimento. Esta definição daria subsídios complementares para uma política de maior adaptação do perfil dos recursos humanos.

Este método de gerenciamento assume a necessidade de questionar a rigidez organizacional, promovendo a mobilidade e a polivalência e de planejar melhor a alocação de recursos humanos, tendo em vista o grau de adaptação dos mesmos às necessidades tecnológicas do trabalho e suas expectativas de satisfação. Assim, a gestão de recursos humanos é vista pelo enfoque como lugar dinâmico de definição das qualidades relativas ao perfil dos recursos que cada forma de atendimento demandaria e de suas possibilidades de satisfação. Da mesma maneira que em relação ao uso da categoria modo de atendimento como possibilidade de diálogo normalizador a serviço da transversalidade, o enfoque assume a gestão de recursos humanos como uma um grande locus de reflexão estratégica sobre a motivação dos profissionais (recursos humanos), para além da especialização, como será desenvolvido mais adiante. 


\section{A Organização da Diversidade ao Redor do Conceito de Modo de Atendimento}

Crémadez e Grateau (1997) partem da premissa de que a evolução tecnológica acarreta vários fenômenos em boa parte articulados: uma diversificação importante dos modos de atendimento; o compartilhamento crescente das infra-estruturas por distintos tipos de profissionais; uma interdependência crescente entre as unidades clínicas e logísticas; a oferta direta por parte das estruturas técnicas de apoio diagnóstico e terapêutico de prestações específicas. Estes fenômenos correspondem, em geral, à dissociação crescente da atividade clínica das infra-estruturas dentro das quais ela se exerce (ela deixa de ser exercida em um único lugar). Isto multiplica e torna mais complexos os processos de trabalho, as combinações de processos e os lugares e condições de exercício profissional,

De territórios quase privados, as unidades de cuidados transformam-se em ferramentas compartilhadas, em tipos de estruturas técnicas cada vez mais diferenciadas, que oferecem aos profissionais e aos pacientes recursos adaptados a uma concepção mais variada e mais aberta das práticas de cuidados.

Há, por conseguinte, uma diversificação crescente dos processos de atenção e, paradoxalmente, um aumento do grau de interdependência dos mesmos e das várias atividades que compõem a cadeia de valor de cada um. A necessidade de uma maior interdependência se expressa tanto no interior de cada hospital quanto entre ele e a rede.

Uma diversidade crescente de atores é mobilizada pelos processos de trabalho, em função de seu caráter cada vez mais transversal. Diante deste panorama, surge a necessidade de um trabalho de gestão da diversidade, de análise e otimização de processos, que possa operar como potente alavanca de comunicação e de compreensão entre os atores envolvidos, e de eficácia, vista pelo lado do controle da qualidade e dos custos. Preocupados com a necessidade de racionalizar o trabalho no interior dos hospitais, Crémadez e Grateau sugerem a proposta de tentar reduzir a diversidade de processos de produção de cuidados, identificando um número limitado de processos operacionais/tipos, correspondentes a modos de atendimento aglutinadores.

O objetivo deste trabalho de gestão ou de organização da diversidade seria promover a modelização, a normalização de um número limitado de processos implementados em tantas estruturas diferentes (de serviços especializados) quanto maior seja o tamanho do estabelecimento. Esta visão, que concede um privilégio à categoria modo de atendimento, rompe com a imagem da prática médica como 
um tipo de prestação que depende fundamentalmente da tecnicidade de seus atos, da personalidade e competência dos profissionais especializados, e que se exerce através de um único modo de atendimento.

Um modo de atendimento é definido como a normalização do processo (ou o conjunto do percurso) que se faz seguir a um paciente, a fim de satisfazer a necessidade que o leva a recorrer à instituição. Um modo de atendimento caracteriza a organização do trabalho no seio da estrutura (hospital, especialidade, serviço) que se dedica à sua implementação, e o tipo de relações que ela mantêm com as unidades prestadoras de serviço que concorrem para este atendimento. Um modo de atendimento é de alguma maneira um processo depurado das particularidades ligadas a um domínio de cuidados preciso (especialidade). Neste sentido, pode-se falar em normalização.

Os principais modos de atendimento identificados são: Hospitalização Convencional; Hospitalização Domiciliar; Consultação; Emergências; Hospitalização Programada de Duração Determinada (reunião de várias especialidades em um mesmo estabelecimento que trata de eventos nosológicos programáveis) etc.

O principal objetivo desta modelização é ajudar à gestão operacional, na medida em que permite padronizar e controlar processos produtivos, com mais qualidade e eficiência, e adequar os recursos (especialmente, os recursos humanos) aos mesmos. Esta normalização ajuda aos prestadores logísticos a adaptar seus serviços às características de cada modelo de atendimento e permite, ainda, definir os níveis de exigência que cada um deles deveria atender para obter uma vantagem comparativa.

Os autores sugerem uma proposta de leitura e de análise destes modelos, constituída de variáveis que permitem identificar as características de cada modo de atenção, e de variáveis que correspondem a fatores determinantes de seu desempenho, como veremos a seguir (Figura 6).

Estas variáveis permitem diagramar os vários modos de atendimento e compará-los. Esta diagramação implica a atribuição por consenso de valores de zero a 4 às dimensões e aos fatores abrangidos pelas variáveis, em função de sua importância relativa para cada modo de atendimento. Apresentaremos dois diagramas correspondentes à emergência e à hospitalização programada de duração determinada (HPDD), considerando os dois tipos de variáveis apontadas (figuras 7 e 8 ). 
Figura 6 - Caracterização de tipos de atendimento.

\begin{tabular}{|l|l|}
\hline \multicolumn{1}{|c|}{$\begin{array}{c}\text { Características dos processos } \\
\text { implementados }\end{array}$} & \multicolumn{1}{c|}{ Comentários } \\
\hline $\begin{array}{l}\text { Parâmetros de Concepção } \\
\text { Controle do tempo } \\
\text { Flexibilidade } \\
\text { Polivalência }\end{array}$ & $\begin{array}{l}\text { Em que medida esta dimensão é considerada? } \\
\text { Há necessidade de se adaptar? } \\
\text { Qual o grau de heterogeneidade das atividades? }\end{array}$ \\
\hline $\begin{array}{l}\text { Nível de Complexidade } \\
\text { Sofisticação técnica } \\
\text { Multiplicidade de intervenientes } \\
\text { Variantes }\end{array}$ & $\begin{array}{l}\text { Grau de sofisticação dos atos praticados? } \\
\text { Os intervenientes são numerosos? }\end{array}$ \\
\hline $\begin{array}{l}\text { Modo de Regulação-Chave } \\
\text { Formalização/Padronização } \\
\text { Ajustamento mútuo entre atores } \\
\text { Programação }\end{array}$ & $\begin{array}{l}\text { Os procedimentos são codificados? } \\
\text { As relações entre atores são densas? }\end{array}$ \\
\hline $\begin{array}{l}\text { Eapacidade de Adaptação } \text { necessário o planejamento? } \\
\text { Descontinuidade } \\
\text { Imprevisto } \\
\text { Incerteza }\end{array}$ & $\begin{array}{l}\text { A variabilidade dos fluxos é fundamental? } \\
\text { O imprevisto é inerente ao modo x ? }\end{array}$ \\
\hline $\begin{array}{l}\text { Atitude-Chave } \\
\text { Proatividade } \\
\text { Reatividade } \\
\text { Seletividade }\end{array}$ & O atendimento é adaptável no processo? \\
\hline
\end{tabular}

\begin{tabular}{|l|l|}
\hline \multicolumn{1}{|c|}{$\begin{array}{c}\text { Fatores determinantes do } \\
\text { desempenho }\end{array}$} & \multicolumn{1}{c|}{ Comentários } \\
\hline $\begin{array}{l}\text { Relação com o Tempo } \\
\text { Observância dos prazos } \\
\text { Dspera }\end{array}$ & $\begin{array}{l}\text { Em que medida a satisfação do paciente } \\
\text { depende da observância de cada um dos } \\
\text { critérios que qualificam a relação com o } \\
\text { tempo característica do modo estudado? }\end{array}$ \\
\hline $\begin{array}{l}\text { Regulação das Interfaces } \\
\text { Antes }\end{array}$ & $\begin{array}{l}\text { Em que medida a qualidade das prestações é } \\
\text { função do controle do que ocorre antes, } \\
\text { durante e depois da hospitalização? }\end{array}$ \\
Depois & $\begin{array}{l}\text { Em que medida a qualidade das prestações } \\
\text { desses tipos influi sobre a satisfação do } \\
\text { paciente? }\end{array}$ \\
\hline $\begin{array}{l}\text { Médicas } \\
\text { Admínticas }\end{array}$ & $\begin{array}{l}\text { Em que medida a qualidade da colaboração } \\
\text { nos três níveis de organização do hospital } \\
\text { influi sobre a qualidade da prestação e sobre a } \\
\text { satisfação do cliente? }\end{array}$ \\
\hline $\begin{array}{l}\text { Integração } \\
\text { Na equipe de base } \\
\text { Com atores complementares } \\
\text { Com outras unidades }\end{array}$ & $\begin{array}{l}\text { Em que medida a qualidade da prestação é } \\
\text { determinada por uma descrição precisa do } \\
\text { campo de ação coberto pelo modo de } \\
\text { atendimento (quem, por que, como?) }\end{array}$ \\
\hline $\begin{array}{l}\text { Formalização } \\
\text { Modo de seleção } \\
\text { Protocolos clínicos } \\
\text { Processos de atendimento }\end{array}$ & \\
\hline
\end{tabular}


Figura 7 - Comparação das características de dois modos de atendimento.

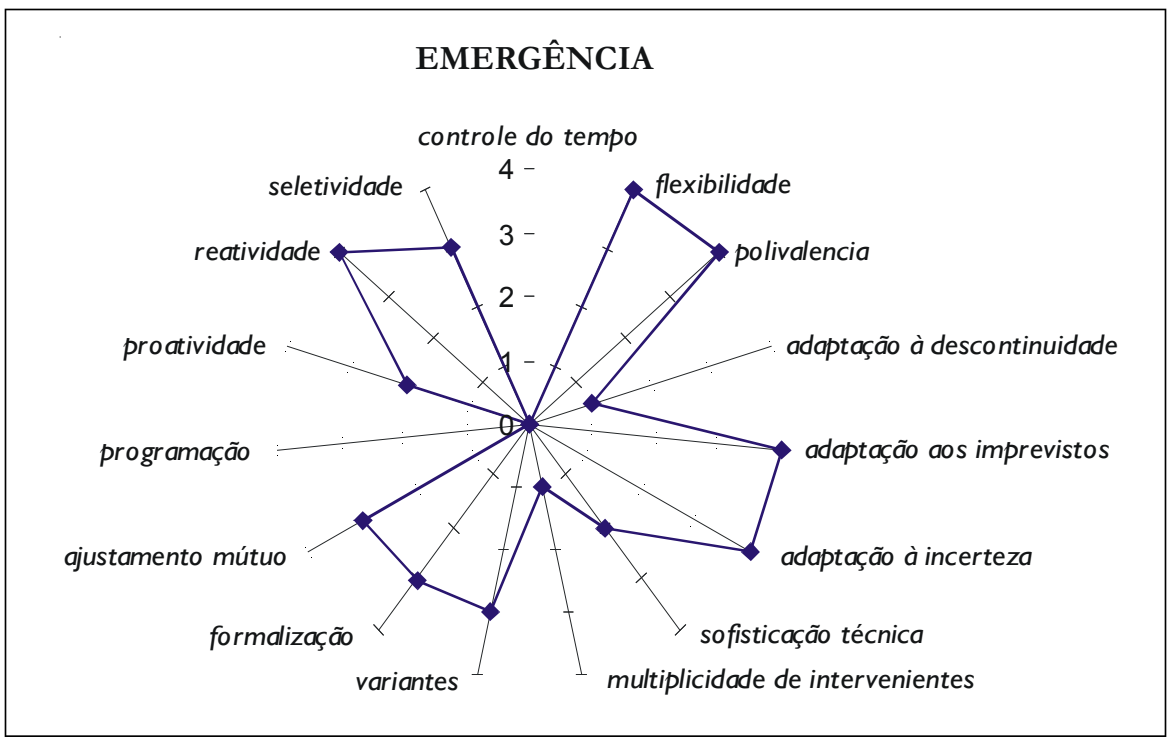

\section{HOSPITALIZAÇÃO PROGRAMADA DE DURAÇÃO DETERMINADA}

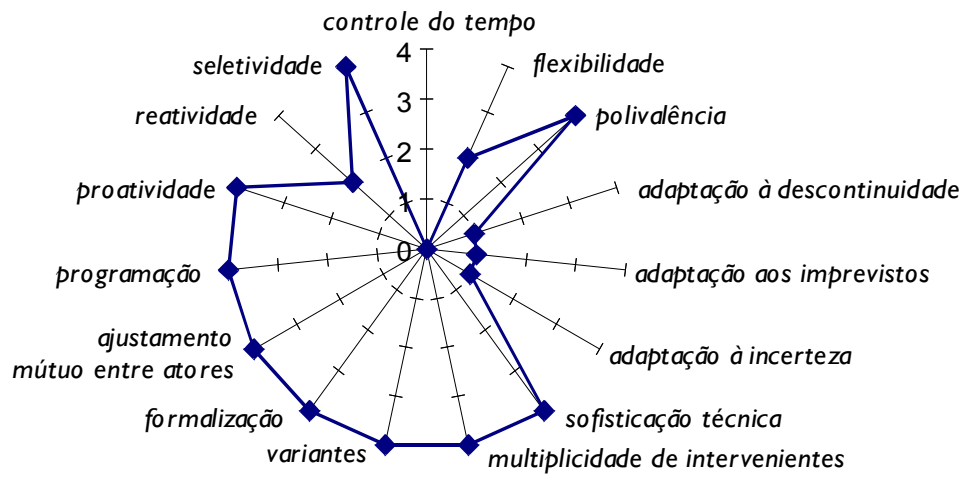


Figura 8 - Comparação dos fatores determinantes do desempenho.

\section{EMERGÊNCIA}

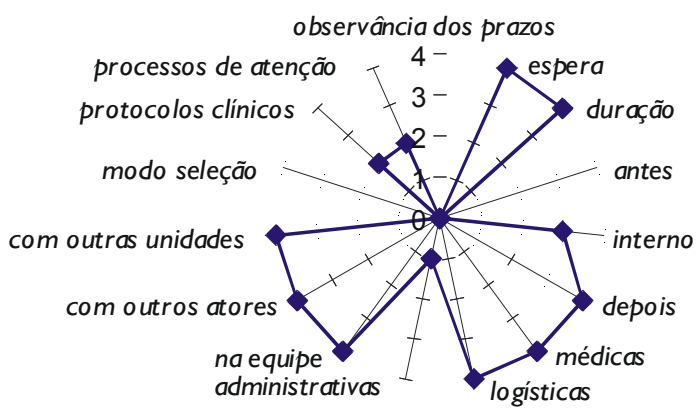

\section{HOSPITALIZAÇÃO PROGRAMADA DE DURAÇÃO DETERMINADA}

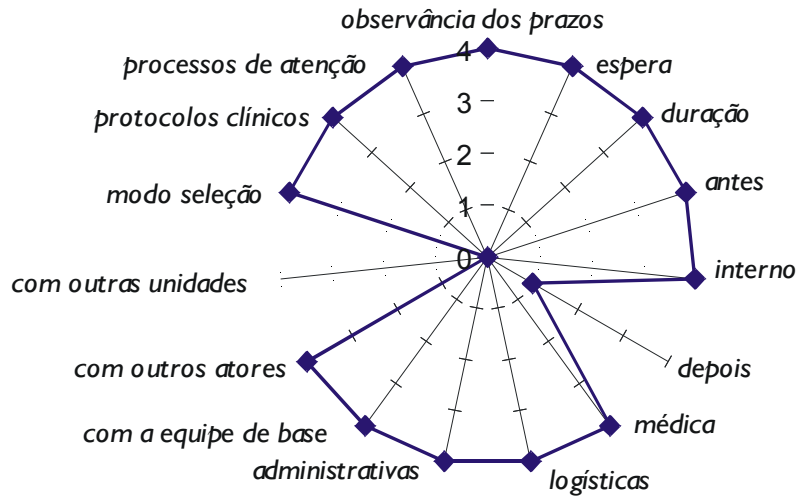


A análise comparativa dos dois modos revela que, do ponto de vista dos fatores determinantes da satisfação, a HPDD é muito mais exigente, considerando-se as possibilidades de obtenção de vantagens comparativas. Ela é altamente sensível a todos os critérios, ao passo que o outro é sensível apenas alguns. Para que o modo HPDD seja bem-sucedido, deve responder de maneira satisfatória ao nível de exigência requerido. Questões como a observância dos prazos, o controle do desempenho administrativo e uma maior padronização de procedimentos são fatores claramente distintivos.

Os dois modos respondem a necessidades diferentes. Isto significa que cada vez que se atenda na emergência um paciente que se beneficiaria mais de uma HPDD, gerar-se-á uma satisfação menor e serão aceitas disfunções que colocarão a instituição em uma posição vulnerável por referência a um concorrente capaz de oferecer um atendimento adaptado.

Uma modelização deste tipo permitiria:

- Encaminhar os pacientes aos modos de atendimento suscetíveis de aumentar sua satisfação.

- Limitar as disfunções ligadas à inadaptação dos processos e das estruturas à diversificação das necessidades.

- Oferecer novas fontes de satisfação aos recursos humanos.

No entanto, a idéia central desta aproximação é permitir a gestação de um diálogo entre profissionais de distintas especialidades em torno de critérios gerenciais, definidos pelos modelos de atendimento apontados. Este processo de comunicação (de alcance progressivamente crescente), visaria a estruturar uma linguagem ou um glossário comum, desenvolver uma capacidade de concepção operacional, capaz de aglutinar, de integrar, de permitir contatos interdisciplinares (Rivera, 1998).

Toda a prática da démarche estratégica objetiva, fundamentalmente, a busca da integração como alternativa à diferenciação das organizações profissionais, resgatando o traço cultural da autonomia, o que significa apostar em processos de gestão ascendentes. Mesmo referindo-se à segmentação estratégica (definição dos produtos das especialidades hospitalares em termos de agrupamentos homogêneos de atividades), esta preocupação está presente: a busca da transversalidade problemática, das sinergias operacionais e culturais.

$\mathrm{Na}$ prática, o resgate do componente gerencial tipo ou modo de atendimento como fenômeno aglutinador introduz una nova forma de transversalidade, que se soma aos critérios população, tecnologia, conjunto de patologias etc. (da segmentação estratégica), que permitiria adensar o campo das possibilidades de estruturas em rede interna (Rivera, 1998). 
Como afirmam os autores (Crémadez \& Grateau, 1997:395):

Depuis quelques anneés, la diversité s'impose progressivement à l'hôpital, sans qu'il soit preparé à l'assumer, ce qui provoque un certain nombre des convulsions dont nous sommes témoins actuallement. Pour y faire face, il lui faut adapter sa culture e ses modes d' action et être capable de plus de formalization pour faciliter la communication qui devient une variable déterminante de l'efficacité en permettant à l'efficience des différents professionnels de mieux se conjuguer. Mais il lui faut aussi apprendre à standardiser ses pratiques sans les uniformizer et sans perdre la flexibilité et l'adaptabilité que lui confere sa caractéristique de structure organique.

A organização da diversidade, coerentemente com a referência, comporta um duplo movimento: normalização-diferenciação. A modelização dos modos de atendimento, em função dos processos abrangidos, suporia o movimento contrário: a adaptação dessa modelização geral ao contexto organizacional específico dos profissionais que organizam suas práticas em função da população específica que atendem, das patologias pertinentes e das tecnologias ad-hoc do serviço.

\section{A Gestão de Recursos Humanos como Interação em Busca da Flexibilidade e da Motivação}

O enfoque estratégico em pauta se propõe a questionar a rigidez organizacional, expressa do ponto de vista dos recursos humanos por dois fenômenos: a falta de mobilidade profissional e a inexistência de uma política de planejamento e de gestão operativa desses recursos, apoiada na busca de uma adaptação entre as exigências de qualidade (de perfil) e as fontes de satisfação implícitas nos processos de trabalho, de um lado, e a alocação de recursos profissionais, de outro.

A alocação de recursos humanos segue, predominantemente, uma via hierárquica, caracterizada pela predominância do critério tecnocrático da especialidade e da disciplina médica, não considerando o critério gerencial da diversidade de formas de prática que uma mesma especialidade pode assumir. Para além da consideração exclusiva das competências técnicas individuais, os autores analisados propõem a necessidade de uma nova concepção de carreiras, horizontal, fundamentada na diversidade de condições de exercício das (mesmas) competências profissionais no hospital.

Neste sentido, eles se apóiam no conceito já analisado de modo de atendimento. Cada um dos modos ou tipos de atendimento identificados corresponde 
a uma "situação profissional", representa uma faceta do fazer médico. Cada um requer qualidades humanas e profissionais singulares, determina condições de trabalho e oferece fontes de satisfação específicas que concedem a um determinado fazer uma riqueza singular.

Trabalhar no centro cirúrgico, em reanimação, em um serviço de geriatria, na unidade ambulatorial de um hospital, na hospitalização domiciliar, na consultação etc. são situações profissionais que requerem aptidões, saberes específicos, competências, características psicológicas diferentes. Por outro lado, estas situações comportam fontes de satisfação e de motivação específicas. Caracterizá-las e utilizar sua riqueza e diversidade para conceber formas de encaminhamento das carreiras e uma gestão de pessoal moderna parece ser primordial. Organizar a mobilidade sobre a base do conceito de modo ou tipo de atendimento pode oferecer múltiplas formas de satisfação, novas motivações e novas perspectivas de evolução para os indivíduos.

Pode-se praticar um exercício análogo ao que foi feito em relação à diferenciação dos modos de atendimento. Basicamente, dois quadros de variáveis podem ser construídos: um, correspondente às qualidades requeridas (em termos de perfil profissional) por cada forma, e outro, representado pelas fontes de satisfação (figuras 9 e 10). Exemplos:

Figura 9 - Exemplos de qualidades requeridas.

\begin{tabular}{|c|c|}
\hline Qualidades requeridas & Comentários \\
\hline $\begin{array}{l}\text { Competências Profissionais } \\
\text { Técnica } \\
\text { Pedagógica } \\
\text { Atualização }\end{array}$ & $\begin{array}{l}\text { Nível de tecnicidade requerido } \\
\text { Exigências de educação dos pacientes } \\
\text { Necessidade de renovar conhecimentos e práticas }\end{array}$ \\
\hline $\begin{array}{l}\text { Aptidões Pessoais } \\
\text { Aptidão de concepção } \\
\text { Aptidão decisional } \\
\text { Aptidão relacional }\end{array}$ & $\begin{array}{l}\text { Conceber e organizar o atendimento } \\
\text { Decidir frente a situações imprevistas } \\
\text { Abrir-se ao próximo e comunicar-se }\end{array}$ \\
\hline $\begin{array}{l}\text { Capacidades de Ação Coletiva } \\
\text { Auto-organização } \\
\text { Trabalho em equipe } \\
\text { Gestão de parcerias }\end{array}$ & $\begin{array}{l}\text { Organização pessoal, método e rigor } \\
\text { Inserção grupal, contribuição ao trabalho } \\
\text { coletivo } \\
\text { Autoridade e senso da negociação }\end{array}$ \\
\hline
\end{tabular}


Figura 10 - Exemplos de fontes de satisfação.

\begin{tabular}{|c|c|}
\hline Fontes de satisfação & Comentários \\
\hline Inserção profissional & $\begin{array}{l}\text { Reconhecimento no seio de um grupo, sentimento } \\
\text { de pertença }\end{array}$ \\
\hline Responsabilidade & Engajamento e capacidade de iniciativa \\
\hline Valorização técnica & Sofisticação das práticas profissionais \\
\hline Carga afetiva & Implicação e sentimento de utilidade Facilidade no \\
\hline Controle da relação com o outro & relacionamento interpessoal \\
\hline Autonomia & Liberdade de ação \\
\hline
\end{tabular}

Estes quadros de variáveis nos permitem estabelecer vários diagramas referentes aos vários tipos de atendimento, onde se procura identificar o nível de exigência de cada variável e o grau de envolvimento dos fatores de motivação assinalados em cada modo específico. Para simplificar e considerando que este trabalho é apenas uma introdução ao tema, apresentaremos os casos da hospitalização convencional e da hospitalização domiciliar (Figura 11).

Figura 11 - Comparação das situações hospitalar e extra-hospitalar.

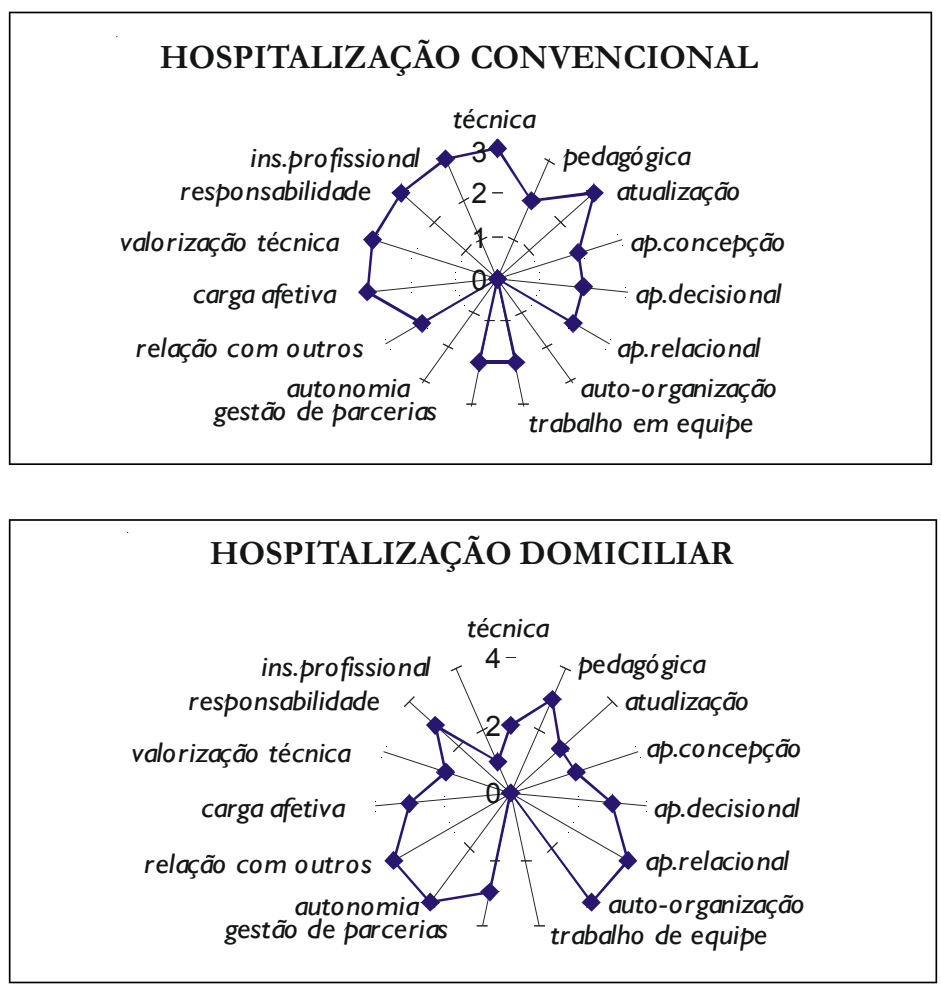


Assim, trabalhar em uma hospitalização em domicílio pode fazer da capacidade de auto-organização um elemento-chave, ao passo que esta apresentará somente um interesse mínimo em um contexto sedentário e estruturado como a hospitalização convencional, que requererá capacidades de trabalho em equipe mas menos desenvolvidas que em uma unidade de tratamento de emergência.

Trabalhar em consultação demandaria menos, no plano das competências técnicas, do que trabalhar na perspectiva da hospitalização programada de duração determinada. Porém, a exigência de atualização técnica não é fundamentalmente diferente. A atitude de concepção seria, no caso da consultação, menos solicitada do que a atitude decisional.

A análise das qualidades requeridas, combinadas com a análise das características e dos fatores de desempenho de um tipo de atendimento permite compreender melhor o clima organizacional, a pressão exercida sobre os indivíduos e apreciar melhor a natureza da atração que ele pode representar (ou não) para os profissionais segundo sua idade, sua motivação, seus antecedentes, assim como seu contexto social. Assim claramente explicitados, os modos ou tipos de atendimento podem permitir a um agente se projetar em um percurso profissional, e à instituição negociá-lo em função de seu perfil e de sua evolução e dos meios que ela pode mobilizar para favorecer num ou noutro sentido profissional.

A partir de uma análise multicritérios, obtêm-se representações dos diferentes tipos de atendimento. $\mathrm{O}$ resultado deste exercício praticado por um grupo profissional homogêneo nos mostra que, para seus membros, a satisfação fornecida pela HPDD está mais ligada à técnica e ao trabalho em equipe enquanto que para a hospitalização domiciliar são os aspectos relacionais e a autonomia que importam. Que a emergência comporta uma carga afetiva bem superior à consultação ou à HPDD.

O exemplo citado pode parecer caricatural, mas é ilustrativo. O que importa é explorar as possibilidades de uma tal aproximação, para o que seria necessário: dispor de um número maior de critérios, cuja definição precisa constituirá um glossário; selecionar e definir os critérios com as pessoas envolvidas (o caráter participativo é essencial); e estabelecer com elas as representações dos vários tipos de atendimento. Devem-se estabelecer e confrontar. A representação que cada grupo profissional tem das características e da atratividade de cada tipo de atendimento, de um lado, e a representação que deles podem ter as equipes de base que os implementam, do outro.

Esta aproximação não deve ser encarada mecanicamente. Trata-se de gerar um diálogo, de providenciar ferramentas úteis aos profissionais para melhor compreender e melhor adaptar-se ao seu universo profissional, inovar e fazê-lo evoluir. Busca-se uma melhor adequação entre indivíduos e organização em uma perspectiva dinâmica, permitindo lhes libertar-se justamente das representações 
caricaturais e ajudando-os a operar as evoluções desejáveis para eles e para a organização onde exercem.

A aproximação anterior pode ter várias aplicações. Uma delas é conceber modalidades de avaliação da carga de trabalho e de determinação do efetivo mais pertinente: assim, a avaliação poderá ser realizada de maneira diferente no caso de uma hospitalização convencional - em que a clientela é mais heterogênea, o serviço, menos codificado, menos formalizado e o tempo, menos restritivo - e no de uma HPDD que fornece serviços de uma variedade limitada e conhecida, a uma clientela selecionada, em um quadro temporal mais restritivo em termos de prazos e de cronologia.

Adaptar os horários e o tempo de trabalho é outra das aplicações: os ritmos de trabalho e os horários poderão ser diferenciados segundo a necessidade de continuidade no atendimento ou ao contrário a ausência de continuidade, mas também segundo a distribuição dos fluxos de pacientes, a importância dos fatores aleatórios ou o controle quantitativo da atividade pela programação.

Por fim, deve-se lembrar de adaptar os indicadores de desempenho individual e fazer emergir a noção de desempenho coletivo. A observância dos prazos predominará em certos casos sobre a duração, a densidade (complexidade) dos pacientes sobre o número.

Mas também, organizar a mobilidade e a polivalência no hospital e conceber os planos de formação conciliando as necessidades institucionais, as necessidades profissionais e as expectativas individuais. A identificação dos tipos de atendimento permite esclarecer aos indivíduos as diferentes possibilidades de exercício profissional que a instituição lhes oferece e explicitar suas características, seus desafios, exigências e vantagens. Uma primeira diferenciação de perfis profissionais está dada pelo conceito de modo ou tipo de atendimento normalizado. Uma segunda diferenciação deverá ser feita no sentido da definição das especificidades existentes no nível de cada tipo de atendimento, especificidades ligadas às exigências particulares das populações e das especialidades médicas. Esta segunda revelará toda a variedade do exercício de cada profissão representada no hospital. A diferenciação de perfis, feita nas duas bases, permitiria oferecer um quadro geral de ajuda à detecção das possibilidades de mudança para os interessados mesmos e para a organização. Esta identificação pressuporia o confronto entre as possibilidades de perfil profissional implícitas nos processos de trabalho e as características específicas dos recursos humanos, aferidas através de processos de avaliação dos mesmos (Figura 12), em que se procuraria levantar em que medida determinadas exigências de perfil profissional são por eles preenchidas. A questão está em saber em que medida determinadas exigências representam pontos fortes ou fracos para um determinado recurso humano. 
Figura 12 - Elementos da avaliação.

\begin{tabular}{|l|l|l|}
\hline $\begin{array}{c}\text { Competências } \\
\text { profissionais }\end{array}$ & Pontos fortes & Pontos fracos \\
\hline $\begin{array}{l}\text { Técnica } \\
1\end{array}$ & & \\
$3 . \ldots \ldots .$. & & \\
\hline Pedagógica & & \\
\hline$\ldots \ldots \ldots \ldots \ldots \ldots . .$. & & \\
\hline Atualização & & \\
\hline
\end{tabular}

Elementos de um balanço de competências (1, 2, 3 etc.corresponderiam a critérios específicos de cada competência que permitiriam qualificá-la melhor).

O objetivo de gerar a mobilidade é oferecer, aos profissionais, a possibilidade de renovar a sua motivação. E do ponto de vista da instituição, permitir uma alocação de recursos humanos mais flexível, que responda às necessidades de curto e longo prazo e mais adaptável, no sentido de um planejamento de RH que leve em conta a evolução da tecnologia e das necessidades. Neste último caso, o componente prospectivo é essencial e pode se manifestar por exemplo através da necessidade de um reequilíbrio entre formas de atendimento (redução relativa da hospitalização tradicional em beneficio da HPDD) ou através da emergência de novas formas de atendimento, como o campo da psiquiatria vem a gerar a partir do momento em que ela decide por sua externalização.

A busca por uma maior flexibilidade e de uma maior adaptabilidade supõe um movimento inverso àquele realizado no sentido de captar a diferenciação que define toda a riqueza do exercício profissional em um hospital. Aumentar a flexibilidade operacional significa definir um marco para organizar a desatomização, os intercâmbios de experiência, as substituições, as equipes de plantonistas, etc. Trata-se de recompor a diversidade buscando não mais os fatores de diferenciação mas os fatores de integração, as proximidades de quaisquer tipos. Os modos ou tipos de atendimento são evidentemente o primeiro nível desta recomposição. Mas pode-se ir além e buscar as similitudes entre modos de atendimento. Os grupos de polivalência assim constituídos permitirão ampliar as possibilidades de gestão qualitativa e quantitativa.

Um grupo de polivalência será constituído, seja por uma reaproximação de tipos de atendimento que valorize características comuns a cada um dos modos reagrupados seja por um reagrupamento de perfis diferenciados cuja proximi- 
dade terá sido julgada sobre um critério diferente (população, patologia, tecnologia). A proximidade deverá ser suficiente para que os profissionais possam revezar-se (mediante um curto prazo de adaptação derivado de uma formação).

Tal forma de gestão das competências dos RH baseada no critério gerencial tipo de atenção, para além do critério técnico da especialidade médica, tem o grande mérito de ser uma forma de gestão que não busca a adequação entre o indivíduo e um posto de trabalho ou que não opera sobre a base da descrição de tarefas a realizar. Ela busca analisar a adequação dos indivíduos a contextos de ação amplos, definidos sob o ângulo organizacional (as relações entre os diferentes atores), sob o ângulo pessoal (as qualidades e motivações individuais) e sob o ângulo estratégico (a qualidade do serviço a fornecer). Desta maneira, busca-se uma aumento global da competência institucional, para além das competências individuais e técnicas. Dada a natureza participativa desta gestão, o que se valoriza são essencialmente as capacidades de auto-organização das unidades e lugares de trabalho.

Uma proposta deste tipo supõe uma nova forma de encarar a formação. A formação deveria estar subordinada aos objetivos institucionais e privilegiar uma concepção mais ampla da eficácia, que implicasse na possibilidade de que os vários atores venham a perceber as interações que condicionam o desempenho global da organização. O desafio é integrar as competências pessoais e profissionais em um quadro coletivo de funcionamento.

Uma proposta nova de formação deveria integrar três dimensões: a das competências necessárias a cada um dos grupos profissionais que compõem o hospital, centradas no conjunto: disciplinas, especialidades e grupos de tecnologias/patologias; a das interações entre profissionais, que caracterizam o modo de funcionamento operacional das unidades de base e os processos implementados; a das relações entre grupos profissionais que condiciona o funcionamento global da organização através do jogo das relações hierárquicas, e das relações logística-tecnoestrutura-centro operacional.

A cada um destes campos corresponderia um tratamento apropriado da formação que permita realizar o indispensável duplo movimento de diferenciação e de integração. Diferenciação pela posta em prática de ações que permitam dotar cada grupo profissional das competências específicas necessárias à boa realização de seu papel, integração pela implementação de ações que permitam aos diferentes profissionais, convocados a colaborar, um melhor controle das condições de sua colaboração. Cada um destes campos está caracterizado por um determinado mix profissional e de conteúdos de formação específicos: dominante técnica para o primeiro, dominante relacional para o segundo, dominante gerencial para o terceiro. $\mathrm{O}$ interesse por este tipo de proposta de formação depende de sua associação a uma renovação da concepção de carreiras de pessoal e à valorização da formação continuada como ferramenta de formação profissional. 


\section{Referências Bibliográficas}

ARTMANN, E. Démarche Stratégique (Gestão Estratégica Hospitalar): um enfoque que busca a mudança através da comunicação e solidariedade em rede, 2002. Tese de Doutorado, Campinas: Departamento de Medicina Preventiva da Faculdade de Ciências Médicas, Unicamp.

CRÉMADEZ, M. \& GRATEAU, F., 1992 (1ª ed.), 1997(2ªed.). Le Management Stratégique Hospitalier. Paris: Inter Éditions.

CROZIER, M. \& FRIEDBERG, E. L'Acteur et le Système. Paris: Éditions du Seuil, 1977.

LAWRENCE, P. R. \& LORSCH, J. H. Adapter les Structures de l'Entreprise. Éditions d'Organisation, 1973.

LE-LUDEC, T. L'Autonomie Stratégique des Établissements de Santé: Frein ou Levier pour la Régulation du Système Hospitalier? Actes du Colloque de la Société Française d'Évaluation des Stratégies. Montpellier, 1995.

MINTZBERG, H. Structure et Dynamique des Organisations. Paris: Éditions d'Organisation, 1982.

PORTER, M. E. Choix Stratégiques et Concurrence. Paris: Ed. Econômica, 1982.

RIVERA, F. J. U. A “démarche” estratégica: a metodologia de gestão do Centro Hospitalar Universitário de Lille, França. Cadernos de Saúde Pública, 13(1):73-80,jan/mar., 1997.

RIVERA, F. J. U. O enfoque de integração estratégica de Crémadez e Grateau e a gestão de recursos tecnológicos e humanos. RAP 32(6):179-208, 1998.

STRATEGOR, Stratégie, Structure, Décision, Identité. Politique Générale d'Entreprise. Paris: Dunod, 1997.

THÉVENET, M., 1986. Audit de la Culture d'Entreprise. Paris: Éditions d'Organization.

UAS-CHRU (Unité d'Analyse Stratégique - Centre Hospitalaire Régional Universitaire), 1995a. La Démarche Stratégique. Guide Méthodologique. Material Instrucional. Lille: UAS-CHRU. (Mimeo.)

UAS-CHRU (Unité d'Analyse Stratégique - Centre Hospitalaire Régional Universitaire), 1995b. La Démarche Stratégique. Sommaire. Material Instrucional. Lille: UAS-CHRU. (Mimeo.) 


\title{
Aplicação da démarche stratégique ao INSTITUTO PHILLIPE PINEL: pensando em rede
}

\author{
Fernando Augusto de Cunba Ramos \\ Liliane Mendes Penello \\ Francisco Javier Uribe Rivera
}

Este capítulo é uma condensação do trabalho final do Curso de Especialização em Gestão Hospitalar da Escola Nacional de Saúde Pública, de 1997. Foi resultado de um estudo desenvolvido por um grupo de alunos da Saúde Mental, predominantemente do Hospital Philippe Pinel. Desta experiência, participaram outros técnicos ligados à gestão estratégica do hospital, dirigido na época pelo Dr. Fernando Augusto da Cunha Ramos, principal responsável por este trabalho. ${ }^{1}$

O Hospital Philippe Pinel era uma unidade federalizada, municipalizada em 1999. Está sediada na Área Programática 2.1 da Secretaria Municipal de Saúde do Rio de Janeiro, no bairro de Botafogo. Esta unidade não restringe seu atendimento à área programática pertinente e aos bairros adjacentes, mas recebe uma população de toda a cidade e as vezes do Estado. Dispõe de atividades tradicionais de internação, de emergência e de ambulatório e recentemente incorporou diversas formas de atendimento na linha do hospital-dia, assumidas cada vez mais como a imagem-objetivo da unidade. São 91 leitos (para pacientes agudos, para unidade de tratamento de alcoolistas e para emergência) e 70 consultórios (distribuídos pelos ambulatórios de adulto e criança, pelos hospitais-dia e outras formas de atendimento pertinentes).

O trabalho original contém, além de uma aplicação do enfoque de gestão estratégica de Crémadez (1992), variações metodológicas importantes que enriquecem sobremaneira o método em si. Realizou-se, por exemplo, uma meta-análise dos fatores-chave de sucesso dos vários segmentos da Unidade, visando a ponderar a importância relativa das principais categorias agrupadas de fatores (metafatores). Também o grupo simulou vários portafólios prospectivos, correspondendo a situações-objetivo a alcançar progres-

1 Participaram do trabalho original, além dos responsáveis pela formatação desta versão, João Luis Barroca de Andrea, João Paulo Bastos Hildebrand, Maria Lelita Xavier e Sonia Maria da Conceição Marçal. 
sivamente em função da implementação da estratégia. Dessa proposta global, apresentamos aqui apenas a parte relativa à aplicação tradicional do enfoque, no intuito de servir como ilustração de como analisar um serviço e preparar uma estratégia de intervenção.

É importante afirmar que esta experiência procedeu, por falta de tempo, a segmentar de maneira intuitiva e estratégica, com base na experiência acumulada. Isto é, o diagnóstico inicial do enfoque não foi desenvolvido de maneira formalizada, embora estivesse incluído de maneira implícita na segmentação.

Toda a parte doutrinária do trabalho, referente ao ideário da reforma psiquiátrica e à proposta dos Centros de Atenção Diária (Caps), também foi retirada, para privilegiar o método de trabalho em si. Isto pode ter significado algum empobrecimento daquele documento original, que se reflete em um tipo de apresentação em que predominam o cálculo e o preenchimento dos formatos do enfoque. Porém, estimamos que este caso ajuda a visualizar a forma de aplicação dos critérios da análise do valor dos segmentos, a análise da competitividade, a leitura de um porta-fólio e a formulação de uma estratégia e de um plano de ação. Complementa, assim, a apresentação do grande arcabouço teórico-metodológico da démarche strategique, feita no capítulo anterior, e ilustra o uso do roteiro de aplicação do enfoque (Anexo).

\section{Aplicação do Método: consideração fase a fase}

\section{A análise do existente}

O IPP acha-se constituído por três macrossegmentos, a saber: assistencial, ensino e pesquisa e administrativo-logístico. Para a análise realizada neste trabalho, optamos por aprofundar o estudo do macrossegmento assistencial, eixo-síntese da missão institucional.

\section{A segmentação estratégica}

O primeiro critério de segmentação adotado foi o de macrossegmentação da missão institucional, fazendo-se o recorte de sua função assistencial. Em seguida realizou-se uma microssegmentação deste recorte inicial, tomando-se como critério principal o modo de atenção e como critérios acessórios os de patologia (Naicap e UTA) e de população (Ambulatório de Adultos, COIJ, Naicap e Cais). 


\section{Segmentos a estudar}

1. Ambulatório de Adultos

2. Centro de Orientação Infanto-Juvenil (COIJ)

3. CAIS (Hospital-Dia de Adultos)

4. Núcleo de Assistência Integral à Criança Autista e Psicótica (Naicap-Hospital-Dia de crianças)

5. Enfermarias A + B (psicóticos/pacientes graves)

6. Unidade de Tratamento de Alcoolistas (UTA)

7. Recepção e Emergência

8. Laboratório (especializado em psiquiatria)

9. Serviço de Imagem Cerebral

Observamos aqui, mais uma vez, a necessidade de se definirem o atual e futuro cenários da Instituição a fim de passarmos à terceira fase do método: a análise do valor (capacidade de atração) dos segmentos e a análise da posição competitiva de cada segmento. Somente a partir destes cenários podemos pensar a adequação dos critérios de avaliação.

\section{Propostas de trabalho (cenário desenhado)}

- Rede de Saúde Mental, organizada em linhas gerais (mínimas) da seguinte forma: Centros de Atenção Diária (mais de um por Área Programática); Sistema de Suporte e Retaguarda de Emergência e Internação (máximo de 01 por AP); Serviços de Referência em Laboratório Especializado e Imagem cerebral (01 para, no mínimo, 02 APs).

- Rede Municipal prevista pela Constituição e pelas Leis Orgânicas da Saúde.

- Vontade política do atual Governo Federal em patrocinar o processo de descentralização de suas unidades.

Trabalhar com o cenário da municipalização, entre outros aspectos, implica (no Município do Rio de Janeiro) um modelo de gestão centralizador, i.e., com baixa autonomia administrativa das unidades. Refletimos que, neste caso, a lógica de rede aponta para uma concorrência mais por recursos do que por clientela. Estaremos disputando: com os Hospitais Gerais, de Emergência ou de Alta Tecnologia (hospitais de custo elevado) e com as Unidades da própria Rede Específica de Saúde Mental. 


\section{A Análise do Valor de Cada Segmento}

A determinação do valor de cada segmento implica a análise de vários critérios genéricos (com subcritérios) que apresentam um peso determinado em termos percentuais. Este peso é variável e relativo entre os diversos critérios, porém mantém-se o mesmo para todos os segmentos estudados. A nota (0-20) dada a cada um dos critérios de valoração constitui o fator variável entre os diversos segmentos. Esta nota acha-se baseada na formulação de questões-chave. Uma nota alta no item possibilidade de crescimento do segmento, por exemplo, corresponderia à previsão de uma forte ampliação deste, e uma nota fraca à estimativa de uma diminuição importante.

O valor global de cada segmento resultará do somatório dos produtos do peso pela nota (= score) de cada critério avaliado. O objetivo central da análise do valor é hierarquizar os segmentos. A matriz utilizada na análise do valor dos segmentos do Instituto Philippe Pinel (IPP) encontra-se a seguir (Figura 1):

Figura 1 - Critérios de avaliação do valor.

\begin{tabular}{|l|c|}
\hline \multicolumn{1}{|c|}{ Critérios de Avaliação } & Peso \\
\hline Contribuição para o projeto político geral & $15 \%$ \\
(e a imagem do hospital) & \\
Motivação Interna & \\
Sinergia com os demais segmentos & $10 \%$ \\
\hline Potencial Regional & $8 \%$ \\
\hline Possibilidade de Crescimento & \\
Intensidade de Concorrência & \\
Possibilidade de Conseguir Recursos Externos & \\
\hline Investimento (barreiras à entrada) & $6 \%$ \\
\hline
\end{tabular}

A distribuição percentual dos pesos refletiu a valoração e hierarquização, por parte do grupo, dos nove critérios já previamente determinados pela matriz da démarche.

Desta forma, entendemos que os itens contribuição para o projeto político geral (e a imagem do hospital), motivação interna, sinergia com os demais segmentos e possibilidades de parceria externa deveriam ter uma importância maior 
na análise do valor e, por isso, atribuímos a cada um desses critérios $15 \%$ de peso. Aos itens potencial regional e possibilidade de crescimento, atribuímos 10\%, ao item intensidade da concorrência $8 \%$ e aos itens possibilidades de conseguir recursos internos e investimentos (barreiras à entrada), $6 \%$. Com esses pesos definidos, passamos a avaliar segmento por segmento, lembrando que o sistema de notação utiliza como instrumento a resultante entre a avaliação de cada critério no cenário projetado (idealizado) e a avaliação do mesmo no cenário atual (real).

Iniciamos, assim, a análise do valor de cada segmento contrapondo dois importantes critérios: sua possibilidade de crescimento comparada à sua contribuição para o projeto político geral e para a imagem da Instituição como um todo. Sugerimos que a análise de cada segmento seja acompanhada de consulta à respectiva matriz, a fim de tornar mais fácil sua compreensão.

\section{A Análise da Posição Competitiva de Cada Segmento e a Avaliação Segundo o Grau de Controle dos Fatores Estratégicos de Sucesso}

Trata-se, nesse caso, de avaliar as vantagens ou condições positivas necessárias para que se tenha êxito em uma atividade.

Os passos a seguir são:

- Identificação dos fatores estratégicos de êxito (fatores chaves de sucesso) ou elementos de capacidade discriminante.

- Levantamento dos concorrentes.

- Ponderação dos fatores estratégicos de êxito (definição de seu impacto ou de seu peso sobre a posição concorrencial).

- Notação.

\section{Segmento I (Ambulatório de Adultos)}

\section{Análise do valor}

Aqui, por exemplo, a possibilidade de crescimento é bastante significativa por conta do fenômeno crescente de medicalização e conseqüente psiquiatrização do mal-estar em nossa sociedade e também porque o modelo ambulatorial constitui uma forma já consagrada e simplificada de assistência extra-hospitalar; 
assim o peso torna-se relativamente grande. A nota, por sua vez, refletirá a resposta do segmento a essa tendência, o que dependerá do projeto político do Instituto. No caso, acreditamos que devemos investir na redução das internações e do tempo médio de permanência dos pacientes, o que significa aumento e qualificação de ações na recepção e emergência e no ambulatório. Por outro lado, consideramos que essa possibilidade de crescimento não deve se dirigir ao ambulatório mais tradicional que conhecemos. Portanto, com relação à sua contribuição para o projeto político institucional, esse ambulatório clássico recebe nota baixa.

A grande concorrência que existe para este segmento implica nota baixa (menor valor de mercado) neste item. Quanto à motivação interna, acreditamos que a chegada de novos profissionais (plausível no cenário da municipalização ou de flexibilização gerencial) - novos tanto no sentido etário quanto no de formação profissional — produzirá um aumento da motivação global: seja diretamente, pelo trabalho destes, seja indiretamente, por meio do contato com profissionais mais antigos.

Os investimentos já realizados nesse segmento não constituem barreiras à entrada de novos investimentos. A notação foi mediana.

A avaliação das sinergias mostra o quanto já se trabalha e o quanto ainda precisamos trabalhar de forma compartilhada. A notação foi alta.

A possibilidade de parcerias externas existe; a notação abaixo da média reflete a resultante da projeção dessa possibilidade no cenário de um Caps, por exemplo, comparada à mesma possibilidade em um ambulatório tradicional.

O potencial regional foi avaliado com nota abaixo da média, considerando que esse atendimento tradicional pode ser feito em vários outros serviços da área (pressupõe uma base territorial indefinida).

A possibilidade de conseguir recursos externos recebeu nota bastante baixa, pela mesma lógica descrita no item parcerias externas. Ressaltamos, no entanto, a possibilidade de sediar pesquisas nas diversas áreas relacionadas ao comportamento humano.

Por esta análise, o segmento obteve o score de 9,36.

\section{Análise da posição competitiva}

Para este segmento, foram estabelecidos os seguintes fatores estratégicos de êxito:

1. Equipe multiprofissional, tecnicamente bem formada e motivada para o trabalho.

2. Acesso a Serviços de Apoio Diagnóstico e Terapêutico (SADT).

3. Disponibilidade de medicamentos. 
4. Flexibilidade de resposta a demanda (tanto no que diz respeito ao tipo quanto ao número de atendimentos oferecidos).

5. Integração à rede de serviços de saúde.

Seguindo o método de análise adotado, partimos para a avaliação do peso de cada item dentro de uma visão prospectiva capaz de projetar um novo modelo de assistência, em que a consulta ambulatorial apareça como um modo de atendimento entre outras modalidades assistenciais, e não corporificada como elemento definidor de um serviço específico e cristalizado.

Passa-se a considerar, na verdade, uma forma de assistência inspirada na experiência dos Caps e Naps, em que cada paciente acha-se vinculado a uma equipe de referência, que deverá acompanhá-lo em qualquer situação que se apresente.

Assim distribuímos o peso, conferindo $25 \%$ para os itens 4 e 5 , respectivamente flexibilidade de resposta à demanda e integração à rede de serviços, uma vez que esses fatores detêm em si a lógica dessa modalidade de atenção.

O item equipe multiprofissional obteve $20 \%$ porque a lógica acima proposta será executada pelos recursos humanos existentes, que precisam estar assim qualificados: profissionais variados, com boa formação técnica, dispostos a interagir uns com os outros e adequadamente motivados para o difícil trabalho a que se propõem.

Os outros dois itens obtiveram 15\% na divisão percentual e representam o acesso a SADT, fundamental para o acompanhamento integral do paciente e monitoramento seguro do tratamento psiquiátrico. A disponibilidade de medicamentos aponta para a garantia de continuidade do tratamento nessa esfera, além da possibilidade de escolha da droga mais indicada para cada caso.

Continuando com as indicações do método, passamos a executar a notação de 0 a 20 para cada um desses itens, considerando a avaliação atual desses fatores e o grau de controle que possuímos sobre os mesmos.

Há uma dificuldade a considerar no que se refere à avaliação da concorrência. Para esta avaliação, recorremos a todas as informações de que dispúnhamos sobre os concorrentes para que conseguíssemos compor um cenário próximo da realidade. Para este segmento, determinamos os seguintes concorrentes: o ambulatório do Instituto de Psiquiatria da Universidade Federal do Rio de Janeiro (IPUFRJ), o atendimento prestado pelos Departamentos e Serviços de Psicologia Aplicada (DPA) da Universidade Federal do Rio de Janeiro (UFRJ), da Universidade Santa Úrsula (USU), e da Pontifícia Universidade Católica (PUC), e Clínicas Sociais das Sociedades Psicanalíticas, todos localizados em nossa Área Programática (AP). 
Os scores finais foram:

- Instituto Philippe Pinel (IPP) $-11,00$

- IPUFRJ - 8,65

- DPA's - 3,00

- Clínicas Sociais - 1,50

Consideramos como forte concorrente o IPUFRJ, principalmente porque caminha na mesma lógica do IPP.

Percebemos que dois itens se destacam no IPP, puxando o score para cima: o acesso a SADT, que em nosso caso concentra-se no segmento Laboratório Especializado, e a disponibilidade de medicamentos, que em nosso caso é excelente.

Quanto à equipe multiprofissional, o IPUFRJ conta com maior variedade de profissionais. Acreditamos, no entanto, que suas dificuldades quanto à integração dos profissionais e à motivação destes para o trabalho são bastante semelhantes às nossas ou até maiores.

No que se refere à flexibilidade de resposta à demanda, a notação foi baixa para ambos, embora com alguma vantagem para o IPP, uma vez que este, em seu papel de pólo de internações, recebe uma demanda espontânea, diferentemente do IPUFRJ, que, por sua face acadêmica, seleciona situações e casos mais adequados à formação de seus alunos de pós-graduação e a seus projetos de pesquisa.

Quanto ao item integração à rede de serviços, as notações também achamse próximas para as duas instituições, porém, pelos mesmos motivos citados, o IPP leva uma pequena vantagem.

A análise desses dois últimos itens nos faz pensar em um outro fator estratégico de êxito que não utilizamos aqui mas que recuperaremos ao final deste trabalho, quando da formulação do plano de ações: trata-se da base territorial (figuras 2 e 3 ). 
Figura 2 - Avaliação do valor (capacidade de atração) do segmento ambulatório de adultos.

\begin{tabular}{|l|c|c|c|}
\hline \multicolumn{4}{|c|}{ Nome do Segmento: Ambulatório de Adultos } \\
\hline \multicolumn{1}{|c|}{ Critérios de Avaliação } & $\begin{array}{c}\text { Peso } \\
\%\end{array}$ & $\begin{array}{c}\text { Nota } \\
0-20\end{array}$ & $\begin{array}{c}\text { Score } \\
(=\mathrm{p} \mathrm{x} \mathrm{n} / 100)\end{array}$ \\
\hline 1. Possibilidade de crescimento & 10 & 15 & 1,50 \\
\hline 2. Intensidade de concorrência & 8 & 8 & 0,64 \\
\hline 3. Investimento (barreiras à entrada) & 6 & 10 & 0,60 \\
\hline $\begin{array}{l}\text { 4. Sinergias (em nível de competências e infra- } \\
\text { estruturas compartilhadas) }\end{array}$ & 15 & 15 & 2,25 \\
\hline 5. Motivação interna & 15 & 10 & 1,50 \\
\hline 6. Possibilidades de parceria externa & 15 & 8 & 1,20 \\
\hline 7. Potencial regional & 10 & 8 & 0,80 \\
\hline 8. Possibilidade de conseguir recursos externos & 6 & 2 & 0,12 \\
\hline $\begin{array}{l}\text { 9. Contribuição para o projeto político geral } \\
\text { (e a imagem do hospital) }\end{array}$ & 15 & 5 & 0,75 \\
\hline Valor do Segmento & 100 & \multicolumn{2}{|c|}{9,36} \\
\hline
\end{tabular}

Figura 3 - Avaliação da posição competitiva do segmento ambulatório de adultos.

\begin{tabular}{|c|c|c|c|c|c|c|c|c|c|}
\hline \multicolumn{10}{|c|}{ Controle dos Fatores Estratégicos de Êxito } \\
\hline \multirow{3}{*}{$\begin{array}{c}\text { Fatores Estratégicos } \\
\text { de Êxito }\end{array}$} & \multicolumn{3}{|c|}{ Hospital } & \multicolumn{6}{|c|}{ Concorrentes } \\
\hline & \multicolumn{3}{|c|}{ IPP } & \multicolumn{2}{|c|}{ IPUFRJ } & \multicolumn{2}{|c|}{ DPAs } & \multicolumn{2}{|c|}{ CSPs } \\
\hline & Peso & Nota & Score & Nota & Score & Nota & Score & Nota & Score \\
\hline $\begin{array}{l}\text { 1. Equipe } \\
\text { multiprofissional motivada } \\
\text { e capacitada }\end{array}$ & 20 & 10 & 2,00 & 13 & 2,60 & 10 & 2,00 & 5 & 1,00 \\
\hline $\begin{array}{l}\text { 2. Acesso a serviços de } \\
\text { apoio diagnóstico }\end{array}$ & 15 & 15 & 2,25 & 12 & 1,80 & 0 & 0,00 & 0 & 0,00 \\
\hline $\begin{array}{l}\text { 3. Disponibilidade de } \\
\text { medicamentos }\end{array}$ & 15 & 20 & 3,00 & 10 & 1,50 & 0 & 0,00 & 0 & 0,00 \\
\hline $\begin{array}{l}\text { 4. Flexibilidade de } \\
\text { resposta à demanda }\end{array}$ & 25 & 5 & 1,25 & 3 & 0,75 & 0 & 0,00 & 0 & 0,00 \\
\hline $\begin{array}{l}\text { 5. Integração à rede de } \\
\text { saúde }\end{array}$ & 25 & 10 & 2,50 & 8 & 2,00 & 4 & 1,00 & 2 & 0,50 \\
\hline Score sobre o segmento & 100 & \multicolumn{2}{|c|}{11,00} & \multicolumn{2}{|c|}{8,65} & \multicolumn{2}{|c|}{3,00} & \multicolumn{2}{|c|}{1,5} \\
\hline Posição Relativa & \multicolumn{3}{|c|}{1} & \multicolumn{2}{|c|}{2} & \multicolumn{2}{|c|}{3} & \multicolumn{2}{|c|}{4} \\
\hline
\end{tabular}

Concorrentes: IPUFRJ, DPA e Clínicas Sociais Psicanalíticas (CSP). 


\section{Segmento 2 (COIJ-Ambulatório Infanto-Juvenil)}

\section{Análise do valor}

Quanto à possibilidade de crescimento, afirmamos que é bastante grande pelos mesmos motivos apontados no segmento 1. Acrescentaríamos aqui, no entanto, a tendência também à psiquiatrização e à medicalização das alterações de comportamento e das dificuldades de aprendizagem manifestadas no ambiente escolar, freqüentemente causadas pela exigência de adaptação a uma estrutura escolar falha e inadequada. Nota alta.

Em relação ao projeto político geral e à imagem do hospital, lembramos que a psiquiatria infantil tem apenas 50 anos de história e que os quadros psiquiátricos graves são menos prevalentes na infância do que na idade adulta. Notação média.

Do ponto de vista das sinergias, é um segmento que por suas especificidades é mais fechado intrainstitucionalmente que o segmento 1. Recebeu nota média. Já a intensidade de concorrência tem poucos concorrentes, o que lhe confere nota alta.

No item barreiras à entrada de novos investimentos, consideramos que já houve por parte da Instituição um grande investimento no setor, o que implica partir de um piso mais elevado para maiores investimentos. Nota acima da média.

A motivação interna para esse tipo de trabalho é grande: trabalhar com crianças descortina um maior leque de possibilidades terapêuticas e estimula o uso de criatividade. Nota alta.

As possibilidade de parcerias externas é grande, tendo em vista a pouca oferta de serviços especializados neste campo, inclusive na área privada. Nota acima da média.

O potencial regional recebe nota acima da média, uma vez que, nesse caso, pelas especificidades, a base territorial tenderá a ser ampla.

Recursos externos recebem nota baixa por conta da situação atual, o que pode ser revertido com uma mudança de cenário.

Score do segmento: 11,91 .

\section{Análise da posição competitiva}

Para este segmento, mantivemos os cinco fatores estratégicos de êxito do segmento anterior, acrescentando ao primeiro, que se refere à equipe, os termos 
interdisciplinar e ampliada que comentaremos mais adiante. Adicionamos, porém, um sexto fator: integração à rede escolar.

Para a avaliação do peso de cada fator apresentado, mantivemos a idéia da análise prospectiva, agora voltada para a prestação de atendimento na área infanto-juvenil.

Observamos que, nessa faixa etária, o peso da equipe sobe para $25 \%$, ou seja, o trabalho integrado dos diferentes profissionais (equipe ampliada e interdisciplinar) traz diferenças bastante significativas para o resultado do trabalho terapêutico com crianças e adolescentes, mesmo no contexto de um serviço ambulatorial. O trabalho com pais e famílias revela-se fundamental, uma vez que boa parte do sofrimento psíquico da criança está relacionado às divisões, cisões e conflitos familiares. Esta característica aumenta significativamente o nível de desafio para a equipe terapêutica, exigindo maior complexidade de atuação independentemente das técnicas ou teorias adotadas.

Pela mesma razão, a integração com o restante da rede de saúde - (principalmente serviços de pediatria) e de educação - é fundamental. É na escola que, amiúde, ocorre pela primeira vez a manifestação do sofrimento da criança, o qual pode se revelar inclusive sob a forma de sintomas corporais, o que chamamos somatização. Para cada um destes itens, estabelecemos $20 \%$ de peso.

Acesso a SADT obteve o mesmo percentual de 15\%, sublinhando aqui o já apontado no segmento anterior, ou seja, a necessidade de monitoramento e acompanhamento integral e seguro do paciente, ainda mais tratando-se de uma criança.

O item disponibilidade de medicamentos não apresenta aqui peso tão importante, uma vez que a psicofarmacologia tem papel menos destacado nessa faixa etária, sendo geralmente desaconselhado o uso de medicação em crianças com menos de seis anos. O trabalho principal é de natureza psicoterápica, fonoaudiológica e de terapia ocupacional, entre outros. Voltamos aqui à importância do funcionamento interdisciplinar da equipe. Passando à notação, lembramos novamente que esta é feita considerando o panorama atual: aqueles recursos com os quais contamos no momento.

A maior notação (20) foi dada à disponibilidade de medicamentos, que é farta, com muitas opções.

O acesso a SADT recebeu nota 15 basicamente por conta da qualidade de nosso laboratório e pela possibilidade de realização de exames eletroencefalográficos na clínica das epilepsias do IPP.

A equipe, como já citamos, precisa necessariamente integrar-se para ser capaz de responder às complexas questões trazidas pelas crianças e suas famílias, o que acaba por produzir maior motivação para o trabalho. A flexibilidade de 
resposta à demanda recebe nota baixa pelas mesmas razões apresentadas na avaliação do segmento anterior. Este item e a maior integração à rede de saúde e à rede escolar são na verdade os pontos cruciais no processo de modificação e de reorganização do modelo assistencial que dispomos. Por isso, na atualidade, recebem nota baixa.

Neste segmento, a análise da concorrência foi feita em relação ao IPUFRJ e ao Instituto de Neurologia Deolindo Couto (INDC). Este último foi escolhido por conta do freqüente encaminhamento de crianças ao neurologista em função de queixa de desligamento ou hiperatividade em sala de aula, geralmente para realizar um eletroencefalograma.

Este segmento, praticamente, não apresenta outros concorrentes, sendo o IPUFRJ a instituição que se encontra mais próxima em termos da assistência prestada. Em geral, a oferta deste tipo de serviço é pequena na rede pública de saúde, especialmente para pré-púberes.

Aqui tampouco analisamos a base territorial, o que será resgatado quando discutirmos o plano de ações.

Nossa posição concorrencial é, segundo nossa análise, superior em relação aos dois concorrentes, entretanto, o IPUFRJ acha-se bastante próximo.

Os scores obtidos foram:

- $\quad$ IPP $-11,35$.

- $\quad$ IPUFRJ $-10,55$.

- $\quad$ INDC - 7,30.

As nossas vantagens em relação ao IPUFRJ ocorrem por conta da melhor disponibilidade de medicamentos e maior flexibilidade de resposta à demanda.

Já a superioridade em relação ao INDC é ainda maior: este não trabalha com a lógica da equipe interdisciplinar, apresenta insuficiente disponibilidade de medicamentos, não tem praticamente qualquer flexibilidade de resposta à demanda, e revela baixa integração à rede de saúde. A integração (relação com) à rede escolar, no entanto, é um pouco maior que a nossa, pelos motivos já expostos (figuras 4 e 5). 
Figura 4 - Avaliação do valor (capacidade de atração) do segmento COIJ.

\begin{tabular}{|l|c|c|c|}
\hline \multicolumn{4}{|c|}{ Nome do Segmento: COIJ (ambulatório infanto-juvenil) } \\
\hline \multicolumn{1}{|c|}{ Critérios de Avaliação } & $\begin{array}{c}\text { Peso } \\
\%\end{array}$ & $\begin{array}{c}\text { Nota } \\
0-20\end{array}$ & $\begin{array}{c}\text { Score } \\
(=\mathrm{p} \mathrm{x} \mathrm{n} / 100)\end{array}$ \\
\hline 1. Possibilidade de crescimento & 10 & 15 & 1,50 \\
\hline 2. Intensidade de concorrência & 8 & 15 & 1,20 \\
\hline 3. Investimento (barreiras à entrada) & 6 & 12 & 0,72 \\
\hline $\begin{array}{l}\text { 4. Sinergias (em nível de competências e infra- } \\
\text { estruturas compartilhadas) }\end{array}$ & 15 & 10 & 1,50 \\
\hline 5. Motivação interna & 15 & 15 & 2,25 \\
\hline 6. Possibilidades de parceria externa & 15 & 12 & 1,80 \\
\hline 7. Potencial regional & 10 & 12 & 1,20 \\
\hline 8. Possibilidade de conseguir recursos externos & 6 & 4 & 0,24 \\
\hline $\begin{array}{l}\text { 9. Contribuição para o projeto político geral } \\
\text { (e a imagem do hospital) }\end{array}$ & 15 & 10 & 1,50 \\
\hline Valor do Segmento & 100 & \multicolumn{3}{|c|}{11,91} \\
\hline
\end{tabular}

Figura 5 - Avaliação da posição competitiva do segmento COIJ.

\begin{tabular}{|l|c|c|c|c|c|c|c|c|c|}
\hline \multirow{2}{*}{ Fatores Estratégicos de Êxito } & \multicolumn{3}{|c|}{ Hospital } & \multicolumn{5}{c|}{ Concorrentes } \\
\cline { 2 - 11 } & \multicolumn{3}{|c|}{ IPP } & \multicolumn{2}{c|}{ IPUFRJ } & \multicolumn{2}{c|}{ INDC } & \\
\cline { 2 - 11 } & Peso & Nota & Score & Nota & Score & Nota & Score & Nota & Score \\
\hline $\begin{array}{l}\text { 1. Equipe interdisciplinar } \\
\text { motivada, capacitada e } \\
\text { "ampliada” }\end{array}$ & $\mathbf{2 5}$ & 15 & 3,75 & 15 & 3,75 & 5 & 1,25 & & \\
\hline $\begin{array}{l}\text { 2. Acesso a serviços de apoio } \\
\text { diagnóstico e terapêutico }\end{array}$ & $\mathbf{1 5}$ & 15 & 2,25 & 15 & 2,25 & 15 & 2,25 & & \\
\hline $\begin{array}{l}\text { 3. Disponibilidade de } \\
\text { medicamentos }\end{array}$ & 5 & 20 & 1,00 & 10 & 0,50 & 5 & 0,25 & & \\
\hline $\begin{array}{l}\text { 4. Flexibilidade de resposta à } \\
\text { demanda }\end{array}$ & 15 & 5 & 0,75 & 3 & 0,45 & 1 & 0,15 & & \\
\hline 5. Integração à rede de saúde & 20 & 8 & 1,60 & 8 & 1,60 & 5 & 1,00 & & \\
\hline 6. Integração à rede escolar & 20 & 10 & 2,00 & 10 & 2,00 & 12 & 2,40 & & \\
\hline
\end{tabular}

Concorrentes: Ipufrj, Instituto de Neurologia Deolindo Couto (INDC). 


\section{Segmento 3 (Cais/Hospital-Dia de Adultos)}

\section{Análise do valor}

Analisando, em conjunto, a contribuição para o projeto político e imagem do hospital e a possibilidade de crescimento, concluímos que este segmento é, atualmente, o que mais se aproxima do novo modelo de atenção que desejamos prestar à clientela. Tal avaliação resultou em nota máxima nos dois casos. Trata-se de sublinhar que, neste segmento, reside o gerador da maior parte dos trabalhos do IPP que trazem em si a chancela do ideário da reforma psiquiátrica, trata-se, portanto, do corpo em expansão do próprio projeto político do Instituto. O Cais é o porto seguro dos pacientes graves, que a ele se vinculam de uma forma diferenciada daquela que acontece na internação tradicional ou no ambulatório clássico. O Cais pode vir a ser, ampliando e diversificando suas ações, o núcleo formador de um verdadeiro Centro de Atenção Diária no Instituto (Caps-IPP).

A intensidade da concorrência é baixa, tendo em vista a diferenciação dos serviços prestados; o que implica nota alta.

O item barreiras à entrada de novos investimentos traz a questão da necessidade de alto investimento neste segmento, principalmente no que se refere a recursos humanos. A nota é alta.

As sinergias já são e deverão ser ainda maiores. Nota alta. A motivação interna é grande para esse trabalho que exige interdisciplinariedade e é inovador. Nota alta.

As possibilidades de parcerias externas são grandes. A demanda por esse tipo de atenção é maior do que a oferta. Nota alta.

O potencial regional é elevadíssimo. Nota alta.

A possibilidade de conseguir recursos externos segue a lógica das parcerias, contudo, a existência da Associação de Amigos do Cais (Amocais) pode se constituir em uma fonte importante de captação de recursos financeiros e materiais. Nota alta.

O segmento obteve o score de 17,80.

\section{Análise da posição competitiva}

No caso deste segmento, relacionamos oito fatores estratégicos de êxito:

1. Equipe interdisciplinar "referenciada".

2. Espaço físico diversificado e ampliado (flexível). 
3. Ações intersetoriais em quatro áreas: trabalho, lazer, educação e habitação.

4. Base territorial/populacional.

5. Acesso a SADT.

6. Forte sinergia interna.

7. Disponibilidade de medicamentos.

8. Atendimento domiciliar.

Os fatores estratégicos de êxito estabelecidos para o Hospital-Dia de Adultos (CAIS) foram avaliados através do processo já explicado: na questão da distribuição de peso, a avaliação foi realizada em termos prospectivos.

Assim, o item mais importante, ao qual conferimos peso 20, nos pareceu aquele referente à base territorial/populacional, delimitada e circunscrita a uma parte de nossa área programática. Aqui a idéia é voltar o atendimento para a população que vive próximo ao serviço, fortalecendo os vínculos entre a instituição e a comunidade. Desta forma, a instituição passa a ser representada por suas equipes de técnicos de referência, dando contornos, vozes e rostos àqueles que prestam assistência a cada paciente, atendido de forma individualizada e de acordo com suas necessidades no momento. $\mathrm{O}$ atendimento de retaguarda à noite, em fins de semana e feriados será prestado pela recepção e emergência do próprio IPP.

Nesse caso, teríamos talvez uma diminuição total do número de pacientes atendidos de forma contínua pela Instituição, porém com evidentes ganhos terapêuticos para a clientela. $\mathrm{O}$ trabalho diferenciado de uma equipe interdisciplinar de referência, que passa a dedicar-se concretamente à função de propiciar continuidade e flexibilidade de atendimento aos seus usuários, é indispensável a um trabalho terapêutico bem conduzido e com chances resolutivas. A este item (equipe), conferimos peso 15, assim como aos itens ações intersetoriais, forte sinergia interna e atendimento domiciliar.

Evidentemente, a idéia aqui apresentada é a de fortalecimento de uma rede dinâmica de cuidados que se movimente em vários sentidos e direções de maneira a atender, no que for possível, às diferentes demandas e necessidades daqueles indivíduos em tratamento na unidade.

Os cuidados demandados são múltiplos e variados, como já vimos, e dependem da complexidade da situação. Os próprios fatores listados dão uma idéia dessas necessidades: desde o atendimento domiciliar, no momento em que o cliente não apresenta condições mínimas para enfrentar o "mundo lá fora", ao uso de um espaço físico adequado (adequação que é flexível), passando pela integração com os demais segmento internos (enfermarias, emergência, farmácia, laboratório etc.), até chegar às áreas não específicas do setor saúde, porém pertencentes ao âmbito da saúde como bem social; ou seja, trabalho, educação, lazer, habitação. 
Quanto à notação, voltada para o aqui e agora, avaliamos que em apenas três itens não precisamos de maiores investimentos, bastando manter o já conquistado: espaço físico adequado, acesso a SADT e disponibilidade de medicamentos.

A equipe atual funciona de maneira bastante integrada, havendo interdisciplinaridade, porém ainda distante da forma plenamente referenciada tal como preconizamos, por isso recebeu nota média.

Os demais itens receberam notação baixa e certamente surgirão como objetivos a serem atingidos em nosso plano de ações.

A análise concorrencial foi feita considerando um hospital-dia público, o do IPUFRJ, e um da área privada, o Casa Verde, hospital-dia credenciado da Caixa de Assistência do Banco do Brasil (Cassi).

O hospital-dia do IPUFRJ assemelha-se ao nosso, com pequena diferença de pontuação. Já o Casa Verde obteve um score bem mais alto, devido aos recursos que tem aos seu dispor na rede credenciada da Cassi. Cabe ressaltar que este hospital não funciona na lógica da base territorial/populacional.

Os scores foram:

- $\quad \mathrm{IPP}-7,35$.

- IPUFRJ - 6,30

- Casa Verde - 12,65.

Dessa forma, em termos de posição competitiva, nosso segmento encontra-se em condições medianas (figuras 6 e 7). 
Figura 6 - Avaliação do valor (capacidade de atração) do segmento Cais.

\begin{tabular}{|l|c|c|c|}
\hline \multicolumn{4}{|c|}{ Nome do Segmento: Cais (Hospital-Dia de Adultos) } \\
\hline & $\begin{array}{c}\text { Peso } \\
\%\end{array}$ & $\begin{array}{c}\text { Nota } \\
0-20\end{array}$ & $\begin{array}{c}\text { Score } \\
(=\mathrm{p} \times \mathrm{n} / 100)\end{array}$ \\
\hline 1. Possibilidade de crescimento & 10 & 20 & 2,00 \\
\hline 2. Intensidade de concorrência & 8 & 18 & 1,44 \\
\hline 3. Investimento (barreiras à entrada) & 6 & 14 & 0,84 \\
\hline $\begin{array}{l}\text { 4. Sinergias (em nível de competências e infra- } \\
\text { estruturas compartilhadas) }\end{array}$ & 15 & 20 & 3,00 \\
\hline 5. Motivação interna & 15 & 15 & 2,25 \\
\hline 6. Possibilidades de parceria externa & 15 & 17 & 2,55 \\
\hline 7. Potencial regional & 10 & 20 & 2,00 \\
\hline 8. Possibilidade de conseguir recursos externos & 6 & 12 & 0,72 \\
\hline $\begin{array}{l}\text { 9. Contribuição para o projeto político geral (e a } \\
\text { imagem do hospital) }\end{array}$ & 15 & 20 & 3,00 \\
\hline Valor do Segmento & 100 & \multicolumn{3}{|c|}{17,80} \\
\hline
\end{tabular}

Figura 7 - Avaliação da posição competitiva do segmento Cais.

\begin{tabular}{|c|c|c|c|c|c|c|c|c|c|}
\hline \multicolumn{10}{|c|}{ Controle dos Fatores Estratégicos de Êxito } \\
\hline \multirow{3}{*}{ Fatores Estratégicos de Êxito } & \multirow{2}{*}{\multicolumn{3}{|c|}{$\begin{array}{c}\text { Hospital } \\
\text { IPP }\end{array}$}} & \multicolumn{6}{|c|}{ Concorrentes } \\
\hline & & & & \multicolumn{2}{|c|}{ IPUFRJ } & \multicolumn{2}{|c|}{ C. Verde } & \multirow[b]{2}{*}{ Nota } & \multirow[b]{2}{*}{ Score } \\
\hline & Peso & Nota & Score & Nota & Score & Nota & Score & & \\
\hline $\begin{array}{l}\text { 1. Equipe interdisciplinar } \\
\text { motivada, capacitada e } \\
\text { "referenciada" }\end{array}$ & 15 & 10 & 1,50 & 10 & 1,50 & 17 & 2,55 & & \\
\hline $\begin{array}{l}\text { 2. Espaço físico diversificado, } \\
\text { flexível e "ampliado" }\end{array}$ & 10 & 15 & 1,50 & 15 & 1,50 & 15 & 1,50 & & \\
\hline $\begin{array}{l}\text { 3. Ações intersetoriais } \\
\text { (habitação, trabalho, cultura, } \\
\text { lazer) }\end{array}$ & 15 & 4 & 0,60 & 4 & 0,60 & 6 & 0,90 & & \\
\hline $\begin{array}{l}\text { 4. Base territorial/ } \\
\text { populacional }\end{array}$ & 20 & 4 & 0,80 & 4 & 0,80 & 0 & 0,00 & & \\
\hline $\begin{array}{l}\text { 5. Acesso a serviços de apoio } \\
\text { diagnóstico e terapêutico }\end{array}$ & 5 & 15 & 0,75 & 10 & 0,50 & 20 & 1,00 & & \\
\hline $\begin{array}{l}\text { 6. Forte sinergia interna com } \\
\text { outros segmentos }\end{array}$ & 15 & 4 & 0,60 & 3 & 0,45 & 18 & 2,70 & & \\
\hline $\begin{array}{l}\text { 7. Disponibilidade de } \\
\text { medicamentos }\end{array}$ & 5 & 20 & 1,00 & 10 & 0,50 & 20 & 1,00 & & \\
\hline 8. Atendimento domiciliar & 15 & 4 & 0,60 & 3 & 0,45 & 20 & 3,00 & & \\
\hline Score sobre o Segmento & 100 & \multicolumn{2}{|c|}{7,35} & \multicolumn{2}{|c|}{6,30} & \multicolumn{2}{|c|}{12,65} & & \\
\hline Posição Relativa & \multicolumn{3}{|c|}{2} & \multicolumn{2}{|c|}{3} & \multicolumn{2}{|c|}{1} & & \\
\hline
\end{tabular}

Concorrentes: IPUFRJ, Casa Verde. 


\section{Segmento 4 - Núcleo de Atenção Integral à Criança Autista e Psicótica (Naicap) - (Hospital-Dia de Crianças)}

\section{Análise do valor}

O hospital-dia infantil obteve nota máxima no que diz respeito ao projeto político geral e imagem do hospital, porque, além de possuir as características já descritas em relação ao Cais, trabalha com a questão da reabilitação de crianças psicóticas, autistas e em grave sofrimento psíquico, o que constitui um serviço raro em nossa precária rede de saúde mental.

A possibilidade de crescimento fica pouco acima da média, porque a parcela da população que demanda atenção nessa área é menor. A intensidade de concorrência é baixíssima, o que implica nota máxima nesse item.

Os investimentos já feitos e as barreiras à entrada seguem a lógica do COIJ e do Cais, com nota acima da média.

As sinergias tendem a ocorrer mais externamente, principalmente com escolas e serviços de pediatria. Poderão, no entanto, aumentar internamente com o COIJ. O fato de ambos os serviços ocuparem atualmente um mesmo prédio planejado especificamente para a assistência de crianças e adolescentes, com várias áreas de uso comum, deve tornar-se um facilitador desta integração. Outro fator de integração refere-se ao fato de os dois serviços agora pertencerem a uma única divisão assistencial no organograma/regimento interno do Instituto. A nota fica acima da média.

A motivação interna é bastante alta, exigindo capacitação, treinamento e supervisão constante dos recursos humanos. Nota alta.

As possibilidades de parcerias externas são grandes, recebendo nota alta. Os recursos externos podem ser conseguidos nessa lógica. Nota mediana.

O potencial regional é altíssimo, com nota máxima.

Score igual a 15,93.

\section{Análise da posição competitiva}

Para este segmento, resolvemos manter os oito fatores estratégicos de êxito estabelecidos para o hospital-dia de adultos (Cais), com pequenas modificações, de forma a adequá-los à faixa etária específica que o serviço atende:

1. Equipe interdisciplinar motivada, capacitada, ampliada e referenciada.

2. Espaço físico diversificado, ampliado e exclusivo. 
3. Ações intersetoriais (educação e lazer).

4. Base territorial/populacional.

5. Acesso a SADT.

6. Forte sinergia com os demais segmentos.

7. Disponibilidade de medicamentos.

8. Atendimento domiciliar.

Quanto ao item equipe interdisciplinar, é interessante observar o quanto foi necessário cercá-la de adjetivos a fim de sublinhar sua adequação para a função holding (suporte), especialmente necessária ao trabalho terapêutico com crianças portadoras de patologias psíquicas graves. Assim, a esse fator conferimos peso 20 em termos percentuais, como também para os dois seguintes, listados também por razões de importância.

A notação deste item foi mediana (10), por considerarmos que nossa equipe atual não reúne todas essas especificações, principalmente no que diz respeito ao funcionamento em modo referenciado pleno.

O item espaço físico, também foi bastante adjetivado, e nesse caso ressaltamos a função setting (os limites e contenções adequadas do ambiente), que também tem especial implicação no tratamento de crianças.

O peso percentual é 20, coincidindo com a notação, pois atualmente contamos com todas essas qualificações.

No que diz respeito às ações intersetoriais, analisamos as articulações existentes com as áreas de educação e lazer. Deu-se, a este item, peso 20 e nota 8, indicando que, no momento, consideramos ainda baixa a integração do segmento com estas áreas.

A base territorial populacional é ampla neste segmento, embora indefinida quanto aos limites. Isto ocorre porque a conjugação dos critérios de segmentação por patologia e por população implicam uma base territorial bastante larga, tendo em vista a baixa prevalência de crianças autistas e psicóticas na população em geral (cerca de quatro a cinco por dez mil crianças). Todavia, a base geográfica ampliada, ao aumentar a distância entre moradia e local de tratamento, dificulta a atenção a crianças com patologias graves, gerando faltas freqüentes e interrupções do tratamento. Assim, levando-se em conta a necessidade de se conciliar a baixa prevalência com a necessidade de definição de uma base territorial geograficamente razoável, pensou-se a proposta de trabalhar com dois Caps infantis: um no IPP, desenvolvido a partir do Naicap-COIJ, e outro no Centro Psiquiátrico Pedro II (CPP-II), baseado no Paicap-Ambulatório Infantil, sendo que este último poderia também funcionar como retaguarda para as raras internações de crianças e adolescentes. Os dois juntos constituiriam (o que já fazem, em parte) centros de referência para 
outros municípios em termos de ensino, pesquisa e assessoria no campo da saúde mental infantil. O Caps-IPP infantil modificaria esse critério por patologias (diagnósticos categoriais), adotando aquele de gravidade.

Em termos percentuais, definimos peso 5, porque, em relação aos demais, esse fator já está parcialmente definido no que diz respeito à amplitude. Falta definir melhor os limites geográficos. A nota baixa também refere-se à atual falta de controle sobre os dois itens mencionados.

Consideramos o item acesso a SADT de grande importância, uma vez que a clientela de crianças autistas e psicóticas necessita de exames específicos e sofisticados (genéticos e imunológicos) para o diagnóstico diferencial destes transtornos. Por isso atribuímos peso percentual 10. A nota 10, por sua vez, refere-se ao fato de não possuirmos esses exames em nosso laboratório.

Em relação à sinergia com os demais segmentos, esta acha-se, na verdade, reduzida, até mesmo pela função setting já descrita. A nota 4 baseia-se em um entendimento de que aquelas sinergias que poderiam estar mais desenvolvidas, por exemplo com o COIJ, ainda não ocorrem.

O item disponibilidade de medicamentos, não tem peso alto nessa área, visto que o uso de medicação não constitui um instrumento terapêutico fundamental; daí o peso 5. A nota 20 (máxima) refere-se ao amplo espectro de medicamentos disponíveis, ainda que não essenciais.

Quanto ao atendimento domiciliar, pelas mesmas razões já consideradas no hospital-dia de adultos, o peso e a nota são, respectivamente, 15 e 4.

A análise da concorrência foi feita em relação ao Programa de Atenção Integral à Criança Autista e Psicótica (Paicap) do CPP-II, que obteve nessa análise algumas vantagens sobre o Naicap, principalmente no que se refere aos seguintes itens:

- Ações intersetoriais (educação) - um convênio com a Secretaria Municipal de Educação (SME) criou a Escola Especial Ulisses Pernambucano. Aí foram matriculadas as crianças atendidas no ambulatório infantil com quadros de psicose e autismo. Este foi o primeiro programa com a SME para acolhimento de crianças com quadros psicóticos. A posteriori é que surge o Paicap, com a proposta de hospital-dia para essas mesmas crianças, sendo esta sua base territorial de referência (rede escolar da região).

- Forte sinergia com os demais segmentos, principalmente, conforme já citado, com o ambulatório infantil.

Os scores são:

- Naicap-10,70.

- $\quad$ Paicap-11,95.

(Ver figuras 8 e 9). 
Figura 8 - Avaliação do valor (capacidade de atração) do segmento - Naicap.

\begin{tabular}{|l|c|c|c|}
\hline \multicolumn{4}{|c|}{ Nome do Segmento: Naicap (Hospital-Dia de Crianças Autistas e Psicóticas) } \\
\hline & $\begin{array}{c}\text { Peso } \\
\%\end{array}$ & $\begin{array}{c}\text { Nota } \\
0-20\end{array}$ & $\begin{array}{c}\text { Score } \\
(=\mathrm{p} \mathrm{x} \mathrm{n} / 100)\end{array}$ \\
\hline 1. Possibilidade de crescimento & 10 & 12 & 1,20 \\
\hline 2. Intensidade de concorrência & 8 & 20 & 1,60 \\
\hline 3. Investimento (barreiras à entrada) & 6 & 13 & 0,78 \\
\hline $\begin{array}{l}\text { 4. Sinergias (em nível de competências e infra- } \\
\text { estruturas compartilhadas) }\end{array}$ & 15 & 12 & 1,80 \\
\hline 5. Motivação interna & 15 & 18 & 2,70 \\
\hline 6. Possibilidades de parceria externa & 15 & 15 & 2,25 \\
\hline 7. Potencial regional & 10 & 20 & 2,00 \\
\hline 8. Possibilidade de conseguir recursos externos & 6 & 10 & 0,60 \\
\hline $\begin{array}{l}\text { 9. Contribuição para o projeto político geral (e a } \\
\text { imagem do hospital) }\end{array}$ & 15 & 20 & 3,00 \\
\hline Valor do Segmento & 100 & \multicolumn{2}{|c|}{15,93} \\
\hline
\end{tabular}

Figura 9 - Avaliação da posição competitiva do segmento Naicap.

\begin{tabular}{|c|c|c|c|c|c|c|c|c|c|}
\hline \multicolumn{10}{|c|}{ Controle dos Fatores Estratégicos de Êxito } \\
\hline \multirow{3}{*}{ Fatores Estratégicos de Êxito } & \multirow{2}{*}{\multicolumn{3}{|c|}{$\begin{array}{c}\text { Hospital } \\
\text { IPP }\end{array}$}} & \multicolumn{6}{|c|}{ Concorrentes } \\
\hline & & & & \multicolumn{2}{|c|}{ Paicap } & \multirow[b]{2}{*}{ Nota } & \multirow[b]{2}{*}{ Score } & \multirow[b]{2}{*}{ Nota } & \multirow[b]{2}{*}{ Score } \\
\hline & Peso & Nota & Score & Nota & Score & & & & \\
\hline $\begin{array}{l}\text { 1. Equipe interdisciplinar } \\
\text { motivada, capacitada, } \\
\text { "ampliada" e "referenciada" }\end{array}$ & 20 & 10 & 2,00 & 10 & 2,00 & & & & \\
\hline $\begin{array}{l}\text { 2. Espaço físico diversificado, } \\
\text { ampliado e exclusivo }\end{array}$ & 20 & 20 & 4,00 & 20 & 4,00 & & & & \\
\hline $\begin{array}{l}\text { 3. Ações intersetoriais } \\
\text { (educação e lazer) }\end{array}$ & 20 & 8 & 1,60 & 15 & 3,00 & & & & \\
\hline $\begin{array}{l}\text { 4. Base } \\
\text { territorial/populacional }\end{array}$ & 5 & 6 & 0,30 & 6 & 0,30 & & & & \\
\hline $\begin{array}{l}\text { 5. Acesso a serviços de apoio } \\
\text { diagnóstico e terapêutico }\end{array}$ & 10 & 10 & 1,00 & 8 & 0,80 & & & & \\
\hline $\begin{array}{l}\text { 6. Forte sinergia com os } \\
\text { demais segmentos }\end{array}$ & 5 & 4 & 0,20 & 10 & 0,50 & & & & \\
\hline $\begin{array}{l}\text { 7. Disponibilidade de } \\
\text { medicamentos }\end{array}$ & 5 & 20 & 1,00 & 15 & 0,75 & & & & \\
\hline 8. Atendimento domiciliar & 15 & 4 & 0,60 & 4 & 0,60 & & & & \\
\hline Score sobre o segmento & 100 & \multicolumn{2}{|c|}{10,7} & \multicolumn{2}{|c|}{11,95} & & & & \\
\hline Posição Relativa & \multicolumn{3}{|c|}{2} & \multicolumn{2}{|c|}{1} & & & & \\
\hline
\end{tabular}

Concorrentes: Paicap. 


\section{Segmento 5 (Enfermarias $A+B$ )}

\section{Análise do valor}

Ao se definir por uma lógica não-asilar, como é o compromisso do IPP, está se escolhendo o caminho da desospitalização e da desinstitucionalização (desospitalização/desinstitucionalização do manicômio, ou seja, do lugar zero da psiquiatria), conseqüentemente, resta ao hospital (às enfermarias) o papel apropriado e circunscrito de lugar de atendimento daquelas situações psiquiátricas agudas que requerem, simultaneamente, intensividade de tecnologias humanas, disponibilidade de equipamentos médicos e proteção ambiental.

$\mathrm{Na}$ lógica do modelo manicomial, há sempre a possibilidade, para não dizer pressão, de crescimento das internações, visto que a exclusão do louco constitui sempre o caminho mais fácil para o enfrentamento de crises em uma sociedade intolerante com a diferença, assim como a via economicamente mais rentável para uma corporação de empresários da área de saúde que vive do financiamento governamental direto. Contudo, dentro do projeto político adotado pelo IPP, em cujo âmbito busca-se ofertar um amplo menu de ações terapêuticas e reabilitadoras, cabe à internação apenas um papel complementar. O ponto futuro deste projeto é a aceleração da tendência já existente de redução das internações e sua substituição por outros modos de atenção. As enfermarias de "portas abertas" existentes no Instituto, limpas, trabalhadas em bom nível técnico, implicam uma diminuição dos preconceitos associados à periculosidade e incurabilidade dos doentes mentais, contrapondo-se à imagem violenta dos quartos fortes, das camisas de força e das grades protetoras, que são marcas registradas do manicômio. Por conta disso, foi dado um peso médio para o critério possibilidade de crescimento e um peso mais alto para o item contribuição para o projeto político geral (e a imagem do hospital). A notação mediana nos dois casos indica que, no cenário desenhado, as enfermarias não tendem ao crescimento.

A intensidade da concorrência é elevada, tendo em vista o fato de que a maior parte dos leitos psiquiátricos da área de referência do IPP estão nos hospitais (manicômios) da rede contratada do SUS. Todavia, sendo a qualidade da assistência prestada nessas instituições muito baixa quando comparada àquela oferecida pelo IPP, estabelecemos um peso relativamente pequeno para este item. A nota também é baixa.

O item barreiras à entrada de outros investidores teve um peso baixo, pelo fato de haver pouco interesse da iniciativa privada, detentora da maior parte dos leitos psiquiátricos, em investir na melhoria dos leitos contratados pelo SUS. No entanto, o mesmo item recebeu uma nota acima da média por conta do impor- 
tante investimento realizado pelo IPP no setor de internação nestes últimos anos em arquitetura de ambiente e hotelaria.

Levando-se em consideração o papel complementar da internação dentro de uma enorme gama de possibilidades terapêuticas, torna-se fundamental a sinergia das unidades de internação com os demais segmentos. Logo, o peso e nota neste item são elevados.

Pelas mesmas razões, o critério motivação interna obteve peso elevado. A nota mediana se refere ao fato de haver ainda uma forte necessidade de investimento em recursos humanos neste segmento.

As possibilidades de parceria, assim como de obtenção de recursos externos são boas, tendo em vista a ótima qualidade assistencial oferecida por este segmento, assim como à possibilidade de sediar pesquisas.

O potencial regional é alto, recebendo valor acima da média.

O segmento obteve o score de 11,09.

\section{Análise da posição competitiva}

Os fatores estratégicos para o êxito do segmento foram:

1. Equipe interdisciplinar motivada capacitada e ampliada (com presença de clínico geral).

2. Integração da equipe técnica de enfermagem.

3. Acesso a SADT.

4. Espaço físico diversificado e "ampliado" (quartos com poucos leitos e banheiros individuais, portas abertas, espaços de convivência e lazer).

5. Forte sinergia com os demais segmentos.

6. Disponibilidade de medicamentos.

Com relação ao primeiro fator, trata-se de garantir a melhor abordagem possível das situações complexas que cercam o sofrimento psíquico e a ruptura de vida dos pacientes internados, assim como o estabelecimento de projetos terapêuticos individualizados, respeitando-se a presença do singular e do diverso nas demandas de cada paciente (superação da massificação e homogeneização das ações típicas do modelo asilar). Para tal, torna-se necessário uma equipe interdisciplinar e com capacidade interativa de responder com ações flexíveis e criativas a situações inesperadas e freqüentemente cercadas de incerteza.

É importante considerarmos, também, que a demanda da clientela por assistência médico-clínica é enorme, uma vez que, amiúde, o corpo do paciente é simplesmente esquecido ou obscurecido pela gravidade da patologia mental. 
O cartesianismo da separação mente-corpo ainda prevalece no pensamento da maioria dos profissionais de saúde, apesar dos avanços ocorridos nas neurociências teóricas e na filosofia da mente. Por outro lado, a população atendida em uma instituição pública de saúde mental, tanto por sua condição socioeconômica (geralmente desfavorável) quanto pelo próprio estigma da doença mental, tem um acesso bastante dificultado a atendimentos médicos em geral. Assim, atribuímos peso 15 e nota 10 a este fator, considerando as atuais limitações do quadro de recursos humanos do hospital.

Consideramos que o fator integração plena da equipe técnica de enfermagem à equipe interdisciplinar é absolutamente estratégico para a superação de uma divisão de trabalho estanque e estática, feita a partir de critérios corporativos e hierárquicos baseados no status profissional. Tal atitude gera um falso trabalho em equipe, visto que não há distribuição de poder e de responsabilidade, ou qualquer grau de compartilhamento de papeis terapêuticos entre os participantes da suposta equipe. O que há, de fato, é uma equipe-pirâmide, cujo vértice é constituído pelo psiquiatra ou pelo psicanalista (que visitam o paciente) e tem a base formada pelos técnicos e auxiliares de enfermagem (que aturam o paciente). $\mathrm{Na}$ ligação entre equipe e paciente internados, os profissionais de enfermagem, principalmente os de nível médio, seja pelo lado específico de seu trabalho (ministrar medicamentos, monitorar sinais vitais, etc.), seja pelo maior tempo de contato com os mesmos, são aqueles que mais interagem com os pacientes. É necessário, portanto, investir na qualificação técnica, na valorização ética e na promoção das condições de trabalho destes profissionais, a fim de que possam mostrar plenamente sua importância no processo de transformação das práticas psiquiátricas tradicionais. $\mathrm{Na}$ mesma medida, este esforço de integração não pode ser unilateral e deve ser feito também junto aos demais profissionais da equipe, que tendem a tratar os profissionais de enfermagem como meros executores de ações prescritivas e que, portanto, criam resistências à integração destes ao conjunto da equipe interdisciplinar. Atribuímos, conseqüentemente, peso 20 a este fator. Contudo, ao receber-se a nota 5 constatam-se as limitações atuais da equipe técnica e a insuficiência de integração.

Quanto ao acesso a SADT, trata-se de um fator estratégico para o planejamento e monitoramento terapêutico de uma clientela internada: tanto o diagnóstico diferencial quanto a segurança no uso de métodos terapêuticos somáticos exigem um ótimo nível de suporte de exames laboratoriais ou de imagem. Atribuímos a este fator peso 15 e nota 15, já que nosso laboratório constitui referência em psiquiatria.

No item seguinte, considera-se fator estratégico o espaço físico diversificado, reconhecendo a importância deste no processo de reforma psiquiátrica. A existência de enfermarias de "portas abertas", repartidas em espaços mais 
privativos, e a oferta de áreas de lazer e de lugares informais de convívio e interação espontânea, superam a "arquitetura asilar", fruto do modelo de exclusão, segregação e abandono, e contribuem significativamente para a transformação das próprias ações terapêuticas. Atribuímos a este fator peso 15 e nota 15 por acreditarmos que nosso espaço físico encontra-se bastante adequado ao novo modelo.

O item forte sinergia, com outros segmentos, constitui fator estratégico por reconhecer que a atenção integral aos clientes, a partir do estabelecimento de vínculos terapêuticos fortes com a equipe técnica, pressupõe a superação dos compartimentos estanques em que as instituições psiquiátricas tradicionais tendem a se cindir: emergência, ambulatório e enfermarias. Atribuímos peso 20 e nota 5 por acreditarmos que ainda precisamos trabalhar bastante esse fator para controlá-lo melhor, bem como superar as divisões internas.

O item disponibilidade de medicamentos é um fator estratégico de grande importância quando se pensa na formulação terapêutica individualizada e adequada a cada paciente, por isso atribuímos peso 15 e nota 20.

Obtivemos boa posição competitiva em relação aos concorrentes, especialmente nos itens: acesso a SADT, forte sinergia com o demais segmentos e disponibilidade de medicamentos. A clínica contratada do SUS avaliada (Clínica da Gávea) não apresentou vantagens em nenhum dos fatores examinados.

Os scores finais foram:

- $\quad$ IPP - 11,00.

- $\quad$ IPUFRJ - 8,95.

- Clínica da Gávea-1,44.

(Ver figuras 10 e 11) 
Figura 10 - Avaliação do valor (capacidade de atração) do segmento enfermarias.

\begin{tabular}{|l|c|c|c|}
\hline \multicolumn{4}{|c|}{ Nome do Segmento: Enfermarias A + B } \\
\hline Critérios de Avaliação & $\begin{array}{c}\text { Peso } \\
\%\end{array}$ & $\begin{array}{c}\text { Nota } \\
0-20\end{array}$ & $\begin{array}{c}\text { Score } \\
(=\mathrm{p} \mathrm{x} \mathrm{n} / 100)\end{array}$ \\
\hline 1. Possibilidade de crescimento & 10 & 10 & 1,00 \\
\hline 2. Intensidade de concorrência & 8 & 8 & 0,64 \\
\hline 3. Investimento (barreiras à entrada) & 6 & 12 & 0,72 \\
\hline $\begin{array}{l}\text { 4. Sinergias (em nível de competências e infra- } \\
\text { estruturas compartilhadas) }\end{array}$ & 15 & 15 & 2,25 \\
\hline 5. Motivação interna & 15 & 10 & 1,50 \\
\hline 6. Possibilidades de parceria externa & 15 & 12 & 1,80 \\
\hline 7. Potencial regional & 10 & 12 & 1,20 \\
\hline 8. Possibilidade de conseguir recursos externos & 6 & 8 & 0,48 \\
\hline $\begin{array}{l}\text { 9. Contribuição para o projeto político geral (e a } \\
\text { imagem do hospital) }\end{array}$ & 15 & 10 & 1,50 \\
\hline Valor do Segmento & 100 & \multicolumn{3}{|c|}{11,09} \\
\hline
\end{tabular}

Figura 11 - Avaliação da posição competitiva do segmento enfermarias.

\begin{tabular}{|c|c|c|c|c|c|c|c|c|c|}
\hline \multicolumn{10}{|c|}{ Controle dos Fatores Estratégicos de Êxito } \\
\hline & \multicolumn{3}{|c|}{ Hospital } & \multicolumn{6}{|c|}{ Concorrentes } \\
\hline \multirow[t]{2}{*}{ Fatores Estratégicos de Êxito } & \multicolumn{3}{|c|}{ IPP } & \multicolumn{2}{|c|}{ IPUFRJ } & \multicolumn{2}{|c|}{ Gávea } & \multirow[b]{2}{*}{ Nota } & \multirow[b]{2}{*}{ Score } \\
\hline & Peso & Nota & Score & Nota & Score & Nota & Score & & \\
\hline $\begin{array}{l}\text { 1. Equipe interdisciplinar } \\
\text { motivada, capacitada e } \\
\text { "ampliada" (+ clínico geral) }\end{array}$ & 15 & 10 & 1,50 & 10 & 1,50 & 3 & 0,45 & & \\
\hline $\begin{array}{l}\text { 2. Integração da equipe } \\
\text { técnica de enfermagem }\end{array}$ & 20 & 5 & 1,00 & 7 & 1,40 & 1 & 0,20 & & \\
\hline $\begin{array}{l}\text { 3. Acesso a serviços de apoio } \\
\text { diagnóstico e terapêutico }\end{array}$ & 15 & 15 & 2,25 & 10 & 1,50 & 0 & 0,00 & & \\
\hline $\begin{array}{l}\text { 4. Espaço físico diversificado } \\
\text { e "ampliado" (portas abertas) }\end{array}$ & 15 & 15 & 2,25 & 15 & 2,25 & 0 & 0,00 & & \\
\hline $\begin{array}{l}\text { 5. Forte sinergia com os } \\
\text { demais segmentos }\end{array}$ & 20 & 5 & 1,00 & 4 & 0,80 & 0 & 0,00 & & \\
\hline $\begin{array}{l}\text { 6. Disponibilidade de } \\
\text { medicamentos }\end{array}$ & 15 & 20 & 3,00 & 10 & 1,50 & 5 & 0,75 & & \\
\hline Score sobre o Segmento & 100 & \multicolumn{2}{|c|}{11,00} & \multicolumn{2}{|c|}{8,95} & \multicolumn{2}{|c|}{1,40} & & \\
\hline Posição Relativa & \multicolumn{3}{|c|}{1} & \multicolumn{2}{|c|}{2} & \multicolumn{2}{|c|}{3} & & \\
\hline
\end{tabular}

Concorrentes: IPUFRJ, Clínica da Gávea. 


\section{Segmento 6 (Unidade de Tratamento de Alcoolistas - UTA)}

\section{Análise do valor}

Aqui, antes de tudo, é preciso destacar que a análise deste segmento foi realizada, conforme exige a metodologia, tomando como pano de fundo a missão institucional, a qual tem como base a questão da loucura e as transformações das práticas psiquiátricas necessárias à formulação de formas inovadoras de atuação em saúde mental capazes de superar o modelo asilar/manicomial. Claramente, o resultado desta análise teria sido diferente se o pano de fundo tivesse sido o da importância epidemiológica que o alcoolismo ocupa dentro de uma política global de saúde pública, uma vez que constitui, no Brasil e no mundo, um dos mais importantes problemas de saúde.

Este segmento traz algumas questões importantes para a análise de seu valor: por exemplo, a segmentação por "patologia" (alcoolismo), na qual o componente psiquiátrico constitui apenas um dos variados aspectos deste transtorno complexo. No alcoolismo, freqüentemente, tanto para efeito de internação quanto em termos de gravidade, evidenciam-se como mais importantes as seqüelas ou manifestações clínicas e neurológicas deste distúrbio do que as alterações psiquiátricas. Tais manifestações médicas (mesmo quando acompanhadas de alterações psiquiátricas) deveriam ser tratadas em unidades/enfermarias de clínica médica, que dispõem dos recursos tecnológicos humanos e materiais adequados para lidar com estas situações, algumas envolvendo importante morbidade e mortalidade.

Para o projeto político-assistencial do Instituto, a lógica seria acolher aquele alcoolista com sofrimento psíquico importante ou com quadro psiquiátrico primário associado (esquizofrenia, transtorno do humor etc.), desde que não predominem os problemas clínicos. Neste caso, não estaríamos excluindo o indivíduo portador de alcoolismo do IPP, mas sim abandonando a segmentação por patologia e adotando aquela por modo de atenção, utilizada para as outras enfermarias, bem como para a maioria dos segmentos da Instituição. Assim, atribuímos nota zero a este item. Em relação à possibilidade de crescimento, no entanto, constatamos que a tradição e o senso comum ainda defendem, fortemente, a internação de pacientes alcoolistas em instituições psiquiátricas, o que implicou uma nota mediana.

A intensidade de concorrência é alta, sendo muitos os concorrentes potenciais. Portanto, nota baixa. O investimento realizado não foi muito grande, o que implica nota abaixo da média. As sinergias intrainstitucionais são insuficientes. Nota baixa.

A equipe que trabalha neste segmento (altamente qualificada) mostra-se 
integrada e motivada, embora necessite de mais pessoal. A notação é acima da média.

Há possibilidades de parcerias externas, pela qualidade do atendimento prestado, o que implica notação acima da média.

No item potencial regional, adotamos notação baixa, uma vez que nesse caso não podemos funcionar como pólo para a internação de pacientes alcoolistas. No IPUFRJ, a internação psiquiátrica constitui apenas uma - e nem sempre a mais importante - das formas de atenção possíveis ou necessárias nestes casos.

Score igual a 6,93 .

\section{Análise da posição competitiva}

Foram listados os seguintes fatores estratégicos de êxito:

1. Equipe interdisciplinar motivada, capacitada e "ampliada" (incluindo clínico geral).

2. Integração da equipe técnica de enfermagem.

3. Acesso a SADT.

4. Suporte hospitalar.

5. Forte sinergia com os demais segmentos.

6. Disponibilidade de medicamentos.

7. Parceria com organizações civis ou estatais que lidam com o alcoolismo.

No item equipe interdisciplinar, a inclusão do médico clínico foi considerada fundamental, devido às freqüentes complicações médicas (seqüelas físicas) observadas nos pacientes com história de uso abusivo de bebidas alcoólicas, especialmente naqueles trazidos a um pronto-socorro, como é o caso do IPP. Foi atribuído peso 15 e nota 1, por conta da dificuldade de se garantir a presença constante desse profissional na equipe, uma vez que o IPP dispõe apenas de um médico clínico para toda a instituição.

No que se refere ao item integração da equipe técnica de enfermagem, consideramos ser um fator importantíssimo de êxito, da mesma forma que o destacamos para as outras duas enfermarias do IPP. Contudo, por não termos chegado a este nível de integração, atribuímos nota 5, apesar do peso 20.

O acesso a SADT é de enorme importância, uma vez serem comuns os quadros clínicos decorrentes do alcoolismo crônico. Tal característica requer instrumentos de apoio diagnóstico e terapêutico adequados. $\mathrm{O}$ peso atribuído foi 20 e a nota, 15, visto já termos controle importante deste fator estratégico 
em função do bom suporte de nosso laboratório.

O item suporte hospitalar, foi pensado, mais uma vez, considerando os freqüentes acometimentos médicos manifestados por pacientes portadores de alcoolismo crônico e que necessitam de internação clínica, assim como a dificuldade de encaminhá-los para a rede pública de hospitais gerais e de emergência, a qual, além de achar-se sucateada e sobrecarregada por uma demanda excessiva, revela preconceitos com relação a essa clientela. O peso atribuído foi 20 e a nota, 5. A nota baixa refere-se ao baixo controle que exercemos sobre este fator.

No item forte sinergia, constatamos que, sendo este segmento definido por patologia, sua sinergia, inevitavelmente, torna-se restrita em uma instituição cuja segmentação se dá marcadamente pelo critério modo de atenção. Nota-se, porém, que o circuito emergência-internação na UTA, com baixa adesão ambulatorial, é notório, o que contribui para a notação e peso igualmente baixos: ambos 5 .

$\mathrm{O}$ item disponibilidade de medicamentos trata-se de fator estratégico pela sua importância na elaboração do plano terapêutico individualizado e capaz de atender à complexidade das manifestações psiquiátricas e complicações clínicas decorrentes do alcoolismo. Atribuíram-se peso 10 e nota 20, porque dispomos de um estoque medicamentoso excelente, porém mais voltado para o quadro psiquiátrico do que para as complicações clínicas.

O fator parceria com (outras) organizações que lidam com o alcoolismo é relevante, considerando a complexidade do problema de saúde pública representado pelo alcoolismo e a insuficiente capacidade de resposta do sistema de saúde formal. Foram atribuídos peso 10 e nota 1, porque, apesar de o IPP abrigar um grupo de Alcoólicos Anônimos (AA), por exemplo, este funciona aos sábados de forma autônoma. Não temos qualquer ligação com Organizações Não-Governamentais (ONGs) que tenham, como foco de interesse, a questão do alcoolismo.

Do ponto de vista da análise da concorrência, obtivemos pequena vantagem em relação ao IPUFRJ, basicamente pelo melhor acesso a SADT, porém, nos demais itens, a análise foi bem semelhante. Em relação à clínica conveniada, obtivemos superioridade em todos os itens, o que não causa estranheza, visto que esta clínica trabalha em modelo predominantemente manicomial.

Os scores são:

- $\quad$ IPP $-8,85$.

- $\quad$ IPUFRJ - 8,60.

- Clínica da Gávea - 1,85.

(Ver figuras 12 e 13)

Figura 12 - Avaliação do valor capacidade de atração do segmento UTA. 
Figura 13 - Avaliação da (posição competitiva) do segmento UTA.

\begin{tabular}{|l|c|c|c|}
\hline \multicolumn{3}{|c|}{ Nome do Segmento: Unidade de Tratamento de Alcoolistas (UTA) } \\
\hline \multicolumn{1}{|c|}{ Critérios de Avaliação } & $\begin{array}{c}\text { Peso } \\
\%\end{array}$ & $\begin{array}{c}\text { Nota } \\
0-20\end{array}$ & $\begin{array}{c}\text { Score } \\
(=\mathrm{p} \mathrm{x} \mathrm{n/100)}\end{array}$ \\
\hline 1. Possibilidade de crescimento & 10 & 10 & 1,00 \\
\hline 2. Intensidade de concorrência & 8 & 5 & 0,40 \\
\hline 3. Investimento (barreiras à entrada) & 6 & 9 & 0,54 \\
\hline $\begin{array}{l}\text { 4. Sinergias (em nível de competências e infra- } \\
\text { estruturas compartilhadas) }\end{array}$ & 15 & 5 & 0,75 \\
\hline 5. Motivação interna & 15 & 12 & 1,80 \\
\hline 6. Possibilidades de parceria externa & 15 & 12 & 1,80 \\
\hline 7. Potencial regional & 10 & 4 & 0,40 \\
\hline 8. Possibilidade de conseguir recursos externos & 6 & 4 & 0,24 \\
\hline $\begin{array}{l}\text { 9. Contribuição para o projeto político geral (e a } \\
\text { imagem do hospital) }\end{array}$ & 15 & 0 & 0,00 \\
\hline Valor do Segmento & 100 & & 6,93 \\
\hline
\end{tabular}

\begin{tabular}{|c|c|c|c|c|c|c|c|c|c|}
\hline \multicolumn{10}{|c|}{ Controle dos Fatores Estratégicos de Exito } \\
\hline \multirow{3}{*}{$\begin{array}{c}\text { Fatores Estratégicos } \\
\text { de Êxito }\end{array}$} & \multirow{2}{*}{\multicolumn{3}{|c|}{$\begin{array}{c}\text { Hospital } \\
\text { IPP }\end{array}$}} & \multicolumn{6}{|c|}{ Concorrentes } \\
\hline & & & & \multicolumn{2}{|c|}{ IPUFRJ } & \multicolumn{2}{|c|}{ Gávea } & \multirow[b]{2}{*}{ Nota } & \multirow[b]{2}{*}{ Score } \\
\hline & Peso & Nota & Score & Nota & Score & Nota & Score & & \\
\hline $\begin{array}{l}\text { 1. Equipe interdisciplinar } \\
\text { motivada, capacitada e } \\
\text { "ampliada" (+ clínico } \\
\text { geral) }\end{array}$ & 15 & 10 & 1,50 & 10 & 1,50 & 3 & 0,45 & & \\
\hline $\begin{array}{l}\text { 2. Integração da equipe } \\
\text { técnica de enfermagem }\end{array}$ & 20 & 5 & 1,00 & 7 & 1,40 & 1 & 0,20 & & \\
\hline $\begin{array}{l}\text { 3. Acesso a serviços de } \\
\text { apoio diagnóstico e } \\
\text { terapêutico }\end{array}$ & 20 & 15 & 3,00 & 10 & 2,00 & 0 & 0,00 & & \\
\hline 4. Suporte hospitalar & 20 & 5 & 1,00 & 5 & 1,00 & 1 & 0,20 & & \\
\hline $\begin{array}{l}\text { 5. Forte sinergia com os } \\
\text { demais segmentos }\end{array}$ & 5 & 5 & 0,25 & 4 & 0,20 & 0 & 0,00 & & \\
\hline $\begin{array}{l}\text { 6. Disponibilidade de } \\
\text { medicamentos }\end{array}$ & 10 & 20 & 2,00 & 20 & 2,00 & 10 & 1,00 & & \\
\hline $\begin{array}{l}\text { 7. Parcerias com } \\
\text { organizações civis ou } \\
\text { estatais que lidam com o } \\
\text { alcoolismo }\end{array}$ & 10 & 1 & 0,10 & 5 & 0,50 & 0 & 0,00 & & \\
\hline Score sobre o Segmento & 100 & \multicolumn{2}{|c|}{8,85} & \multicolumn{2}{|c|}{8,60} & \multicolumn{2}{|c|}{1,85} & & \\
\hline Posição Relativa & \multicolumn{3}{|c|}{1} & \multicolumn{2}{|c|}{2} & \multicolumn{2}{|c|}{3} & & \\
\hline
\end{tabular}

Concorrentes: IPUFRJ, Clínica da Gávea. 


\section{Segmento 7 (Recepção e Emergência)}

\section{Análise do valor}

Este segmento, se levarmos em conta a política/conjuntura de saúde pública vigente, que estimula a demanda por atendimentos de emergência (em detrimento da atenção básica ou de reabilitação) em uma rede de serviços públicos sucateada e desorganizada, quando avaliado em relação à sua possibilidade de crescimento, recebe, naturalmente, notação alta. Não é incomum, por exemplo, que um indivíduo apresentando forte cefaléia acompanhada de insônia, e que tenha um atendimento negado em serviços de clínica médica ou neurologia, procure a Emergência do IPP, porque é onde acaba obtendo algum atendimento. Do ponto de vista do paciente, não faz diferença se a assistência que recebe é clínica, neurológica ou psiquiátrica. O que ele procura (e tem dificuldade de obter) é um atendimento médico qualquer. O que percebemos, apesar de todas as explicações dadas ao usuário a respeito dessas diferenças, é que este, comumente, sentindo-se "bem atendido", tende a retornar ao serviço, buscando outro atendimento para si ou para seus familiares, amigos e vizinhos.

Assim, o bom (relativo) atendimento funciona como estimulador da demanda de clientelas diversas que deveriam estar sendo atendidas em outros serviços. Esta pressão de demanda aumenta nossa dificuldade em atender adequadamente aquela parte da população portadora de transtornos mentais que nos cabe assistir com cuidado especial a fim de interromper o circuito emergênciainternação, ou seja, o início ou a perpetuação de uma "carreira psiquiátrica". Por tudo isso, a nota é bastante baixa no item contribuição para o projeto político do hospital e a imagem do hospital.

A intensidade de concorrência é baixa (apenas com o que restou do setor público), o que nos confere nota máxima.

O investimento feito acha-se, mais ou menos, na mesma ordem de grandeza das demais enfermarias, por conta dos Leitos Diagnósticos. A nota é mediana.

As sinergias devem ocorrer internamente e externamente nos contatos com a rede. Nota alta.

Quanto à motivação interna, a notação é bastante baixa. Os profissionais que aí trabalham sofrem exigências de todas a sorte, enfrentando dificuldades de natureza prática, técnica e ética, como, por exemplo, serem obrigados a realizar verdadeiras "escolhas de Sofia", onde têm de decidir quais pacientes deverão receber o melhor tratamento. $\mathrm{Na}$ emergência clássica, acaba-se respondendo superficialmente apenas à demanda por atendimento, e não às verdadeiras necessidades de vida e de saúde da clientela. 
Já a possibilidade de parcerias externas, dentro do modelo clássico, é grande. Nota alta. Também há possibilidade de obtenção de recursos externos, recebendo nota pouco abaixo da média.

O potencial regional também é alto, pois funciona como pólo. Nota alta. Score do segmento igual a 11,38 .

\section{Análise da posição competitiva}

Para esse segmento foram estabelecidos os seguintes fatores estratégicos de êxito:

1. Equipe interdisciplinar motivada, capacitada e ampliada.

2. Base territorial/populacional.

3. Ações intersetoriais (justiça).

4. Atendimento domiciliar.

5. Integração à rede de saúde.

6. Forte sinergia com os demais segmentos.

7. Acesso a SADT.

8. Disponibilidade de medicamentos.

O item equipe interdisciplinar recebe a qualificação adicional de ampliada porque devem estar presentes, além dos outros profissionais de saúde mental, psiquiatras emergencistas e um clínico geral. Trata-se de fator estratégico fundamental para permitir uma melhor abordagem e manejo das situações de urgência e crise, superando o modelo tradicional dos pronto-socorros psiquiátricos (PSP). Esses, freqüentemente, tanto pela proposta assistencial inadequada quanto pelas péssimas condições de funcionamento, não alcançam eficácia alguma, acabando por se transformar, burocraticamente, em meros serviços de triagem de pacientes para internação. Isto resulta em internações tanto desnecessárias quanto prolongadas. Uma melhor abordagem das emergências reduz, rapidamente, o número de internações psiquiátricas, o que foi demonstrado em 1983, com a regionalização da assistência psiquiátrica no Município do Rio de Janeiro e a criação dos cinco pólos regionais de emergência e emissão de Autorizações de Internação Hospitalar (AIH).

A presença do psiquiatra emergencista e a do clínico são fundamentais para a ótima realização de um diagnóstico diferencial, particularmente naquelas situações em que transtornos orgânicos acham-se associados aos quadros psiquiátricos. Um bom diagnóstico diferencial, mesmo entre os transtornos psiquiátricos, é de fundamental importância na priorização dos cuidados imediatos a se- 
rem prestados, assim como para o subseqüente planejamento terapêutico. Estabelecemos, para este item, peso 20. A nota 12 indica que ainda não obtivemos suficiência neste item.

O item base territorial foi considerado fator estratégico de êxito à luz de um novo paradigma para a reorganização da assistência psiquiátrica, onde o prontosocorro psiquiátrico deixa de ser o portão escancarado do hospício para ser a porta de entrada de uma rede de cuidados diversificada e territorializada (Caps, Naps, lares abrigados, pensões protegidas etc.). A lógica territorial prevê uma intensa solidariedade entre a instituição de saúde e a comunidade assistida, o que é indispensável a uma assistência de qualidade em saúde mental. Vemos, assim, a definição de uma base territorial como condição necessária a um planejamento de ações que pressuponha a responsabilização de todos os atores envolvidos.

A recepção/emergência do IPP como referência para toda a AP-2 implica uma base territorial excessivamente grande para ser eficaz, porém poderia assumir o papel de retaguarda para uma rede local de Centros de Atenção Diária. Essa forma de organização será melhor esclarecida, ao final deste trabalho, na ilustração gráfica que denominamos mandala territorial do IPP. O peso 15 considerou a importância deste fator. A nota 5 leva em conta o baixíssimo controle que possuímos sobre o mesmo. Nesse ponto devemos considerar a falência da rede pública (fechamento dos pólos da AP-5 e AP-1), restando ao IPP e ao CPP-II a maior parte da responsabilidade pelos atendimentos de emergência do município do Rio de Janeiro e dos da Baixada Fluminense.

As ações intersetoriais foram consideradas principalmente no aspecto relacionado à área judicial. Aqui preocupam-nos, especialmente, as questões éticolegais envolvendo as internações involuntárias e a repercussão destas sobre os direitos humanos e o exercício de cidadania dos pacientes psiquiátricos. $\mathrm{O}$ peso 5 aponta para a necessidade de estabelecimento dessa via de ação, ao passo que a nota 0 demonstra a ausência atual de controle sobre esse fator.

O item atendimento domiciliar relaciona-se estreitamente ao estabelecimento de uma base territorial, pois dela depende. A realização de atendimentos domiciliares representa a possibilidade de superação da cena tradicional e banalizada de pacientes trazidos ao pronto-socorro psiquiátrico por viaturas policiais ou por carros do corpo de bombeiros, freqüentemente de forma arbitrária e violenta. $\mathrm{O}$ peso 15 refere-se à importância do fator. A nota 0 indica a ausência de controle sobre o mesmo.

A integração à rede de saúde consiste em fator estratégico por ser a garantia das referências e contra-referências da clientela no âmbito da rede pública de saúde, notadamente para o encaminhamento de situações médicas de urgência, para a reorientação da clientela em busca de outros tipos de tratamento e para o encaminhamento da clientela necessitada de atendimento extra-hospitalar em 
saúde mental. O peso relativamente alto refere-se à importância do fator e a nota baixa à nossa falta de controle sobre o mesmo.

Forte sinergia interna é fator estratégico por considerar a necessária relação entre o bom funcionamento da porta de entrada, mormente na perspectiva de criação de um Caps/IPP, e o nível de integração desta com os demais segmentos da Instituição. A notação baixa demonstra o insuficiente controle deste fator na atualidade.

O acesso a SADT constitui, sem dúvida, fator estratégico para a adequada avaliação diagnóstica de uma clientela em situação de crise/emergência. Trata-se de ferramenta indispensável para que uma equipe interdisciplinar ampliada possa, como já ressaltado, realizar um bom diagnóstico diferencial. Atribuímos peso máximo a este item. A nota 8 refere-se ao controle ainda insuficiente que temos sobre esse fator, principalmente pelo fato de nosso laboratório não funcionar nas 24 horas, nem todos os dias da semana.

O item disponibilidade de medicamentos é indiscutivelmente importante no atendimento aos quadros emergenciais, porém a ele atribuímos peso baixo, visto que nessa fase do tratamento não é necessária grande variedade de medicamentos. A nota 20, no entanto, aponta para a grande disponibilidade e diversidade de medicações no IPP.

A porta de entrada credenciada da Cassi, Casa Verde, embora não trabalhe plenamente com a lógica da equipe interdisciplinar, dispõe de ampla variedade de profissionais. O Casa Verde não trabalha com ações intersetoriais, nem tampouco realiza atendimento domiciliar com sua própria equipe, mas através de serviços contratados. O que mais o diferencia, entretanto, são os fatores: acesso a SADT, integração a rede de saúde e disponibilidade de medicamentos. Isto ocorre devido à ampla rede credenciada da Cassi.

O CPP-II apresenta-se em desvantagem em todos os itens relacionados, exceto no que diz respeito à disponibilidade de medicamentos, que é boa.

Os scores são:

- $\quad$ IPP - 6,35.

- CPP-II - 4,25.

- Casa Verde - 14,00.

(Ver figuras 14 e 15) 
Figura 14 - Avaliação do valor (capacidade de atração) do segmento recepção e emergência.

\begin{tabular}{|l|c|c|c|}
\hline \multicolumn{4}{|c|}{ Nome do Segmento: Recepção e Emergência } \\
\hline \multicolumn{1}{|c|}{ Critérios de Avaliação } & $\begin{array}{c}\text { Peso } \\
\%\end{array}$ & $\begin{array}{c}\text { Nota } \\
0-20\end{array}$ & $\begin{array}{c}\text { Score } \\
(=\mathrm{p} \mathrm{x} \mathrm{n/100)}\end{array}$ \\
\hline 1. Possibilidade de crescimento & 10 & 15 & 1,50 \\
\hline 2. Intensidade de concorrência & 8 & 20 & 1,60 \\
\hline 3. Investimento (barreiras à entrada) & 6 & 10 & 0,60 \\
\hline $\begin{array}{l}\text { 4. Sinergias (em nível de competências e infra- } \\
\text { estruturas compartilhadas) }\end{array}$ & 15 & 15 & 2,25 \\
\hline 5. Motivação interna & 15 & 3 & 0,45 \\
\hline 6. Possibilidades de parceria externa & 15 & 15 & 2,25 \\
\hline 7. Potencial regional & 10 & 15 & 1,50 \\
\hline 8. Possibilidade de conseguir recursos externos & 6 & 8 & 0,48 \\
\hline $\begin{array}{l}\text { 9. Contribuição para o projeto político geral (e a } \\
\text { imagem do hospital) }\end{array}$ & 15 & 5 & 0,75 \\
\hline Valor do Segmento & 100 & & 11,38 \\
\hline
\end{tabular}

Figura 15 - Avaliação da posição competitiva do segmento recepção e emergên-

\begin{tabular}{|c|c|c|c|c|c|c|c|c|c|}
\hline \multicolumn{10}{|c|}{ Controle dos Fatores Estratégicos de Êxito } \\
\hline \multirow{3}{*}{ Fatores Estratégicos de Exxito } & \multirow{2}{*}{\multicolumn{3}{|c|}{$\begin{array}{c}\text { Hospital } \\
\text { IPP }\end{array}$}} & \multicolumn{6}{|c|}{ Concorrentes } \\
\hline & & & & \multicolumn{2}{|c|}{ Casa Verde } & \multicolumn{2}{|c|}{ CPP-II } & \multirow[b]{2}{*}{ Nota } & \multirow[b]{2}{*}{ Score } \\
\hline & Peso & Nota & Score & Nota & Score & Nota & Score & & \\
\hline $\begin{array}{l}\text { 1. Equipe interdisciplinar } \\
\text { motivada, capacitada e } \\
\text { "ampliada" }\end{array}$ & 20 & 12 & 2,40 & 15 & 3,00 & 5 & 1,00 & & \\
\hline 2. Base territorial/populacional & 15 & 5 & 0,75 & 15 & 2,25 & 5 & 0,75 & & \\
\hline 3. Ações intersetoriais (justiça) & 5 & 0 & 0,00 & 0 & 0,00 & 0 & 0,00 & & \\
\hline 4. Atendimento domiciliar & 15 & 0 & 0,00 & 5 & 0,75 & 0 & 0,00 & & \\
\hline 5. Integração à rede de saúde & 10 & 3 & 0,30 & 20 & 2,00 & 3 & 0,30 & & \\
\hline $\begin{array}{l}\text { 6. Forte sinergia com os demais } \\
\text { segmentos }\end{array}$ & 10 & 3 & 0,30 & 10 & 1,00 & 2 & 0,20 & & \\
\hline $\begin{array}{l}\text { 7. Acesso a serviços de apoio } \\
\text { diagnóstico e terapêutico }\end{array}$ & 20 & 8 & 1,60 & 20 & 4,00 & 5 & 1,00 & & \\
\hline $\begin{array}{l}\text { 8. Disponibilidade de } \\
\text { medicamentos }\end{array}$ & 5 & 20 & 1,00 & 20 & 1,00 & 20 & 1,00 & & \\
\hline Score sobre o Segmento & 100 & \multicolumn{2}{|c|}{6,35} & \multicolumn{2}{|c|}{14,00} & \multicolumn{2}{|c|}{4,25} & & \\
\hline Posição Relativa & \multicolumn{3}{|c|}{2} & \multicolumn{2}{|c|}{1} & \multicolumn{2}{|c|}{3} & & \\
\hline
\end{tabular}

Concorrentes: Casa Verde, Centro Psiquiátrico Pedro II (CPP-II). 


\section{Segmento 8 (Laboratório Especializado em Psiquiatria)}

\section{Análise do valor}

O laboratório do IPP recebeu importante investimento nos últimos anos em termos de novos recursos tecnológicos. O seu valor para a instituição é alto à medida que oferece apoio seguro no campo diagnóstico e terapêutico, garantindo resultados de qualidade e confiáveis para os usuários e técnicos do IPP. Em termos de contribuição para o projeto político geral, trata-se de um serviço de apoio que, por sua excelência e destaque na rede, contribui significativamente para a imagem do Instituto. Nota acima da média.

A possibilidade de crescimento é grande. A produção atual do laboratório do IPP já inclui um importante percentual de exames realizados para pacientes de outras instituições da rede pública de saúde, demonstrando a existência de parcerias externas. A nota é, portanto, alta. O laboratório tem capacidade de tornar-se referência para mais de uma área programática (desde que aumente o número de seus técnicos), quem sabe para todo o município. A nota é alta, assim como aquela destinada ao potencial regional.

A intensidade de concorrência é pequena, por conta dos exames específicos que realiza, tendo nota bastante alta neste item.

Com relação ao item barreiras à entrada para novos investimentos, o investimento já feito é grande, o que exige de novos investidores um investimento equivalente para se equipararem ao nível atingido pelo IPP. Nota alta.

As sinergias são grandes, pois há integração com todos os setores do IPP. Nota alta.

A motivação interna é boa, havendo, no entanto, falta de pessoal técnico. Nota mediana. Também é boa a possibilidade de conseguir recursos externos na lógica de parceria. Nota acima da média.

Score atingido igual a 14,52 .

\section{Análise da posição competitiva}

São os seguintes os fatores estratégicos de êxito do segmento:

1. Analisador de bioquímica, drogas e lítio.

2. Analisador de hormônios e imunocomponentes.

3. Centrífuga preparadora de líquor.

4. Profissionais qualificados (nível médio e superior). 
5. Abastecimento adequado de material de consumo.

6. Renovação contínua do parque de equipamentos.

7. Manutenção preventiva e corretiva do parque de equipamentos.

8. Parcerias externas.

9. Controle de qualidade permanente (interno e externo).

Para o item analisador de bioquímica, que já possuímos, atribuímos peso 15 e nota 20.

Para o item 2 atribuímos peso 10, tendo em vista a sabida importância do analisador de hormônios e imunocomponentes para a formulação de diagnósticos diferenciais mais precisos e no controle de possíveis síndromes iatrogênicas, tais como o hipotireoidismo e a hiperprolactinemia. A nota 0 é por não contarmos ainda com esse recurso.

O item centrífuga preparadora de líquor apresenta um peso ligeiramente menor do que o do item anterior por ter uma utilidade mais restrita. A notação (zero) se deve à inexistência deste equipamento.

Quanto aos recursos humanos necessários para o adequado funcionamento do laboratório, atribuímos peso 15 e nota 10, pois, no momento, contamos com cerca da metade dos recursos estimados ideais.

Os três próximos itens falam de abastecimento adequado de material de consumo, renovação contínua do parque de equipamentos (que pode se dar pelo instrumento do comodato) e manutenção preventiva e corretiva dos mesmos. A eles atribuímos pesos e notas medianos, com exceção do item manutenção, uma vez que já contamos com contratos adequados para este fim.

Parcerias externas e controle de qualidade já vêm se desenvolvendo (por isto nota mediana), contudo podem crescer bastante. $\mathrm{O}$ item controle de qualidade permanente deve chegar às especificações do Inmetro, por exemplo. Quanto às parcerias externas, entendemos que estas podem servir também como moeda de troca para a obtenção de acesso a serviços de imagem cerebral, que constitui o objeto do próximo segmento estudado.

Para a avaliação concorrencial utilizamos os laboratórios do IPUFRJ, do Hospital Municipal Rocha Maia (HMRM) e do Hospital-Dia Casa Verde, ou seja: uma unidade pública da rede de saúde mental, uma unidade pública da rede de saúde geral e uma unidade privada credenciada da Cassi, respectivamente. Na competição com as unidades públicas, obtivemos melhor posicionamento, basicamente por conta dos recursos tecnológicos e humanos que de que já dispomos, aliados a uma adequada manutenção do parque de equipamentos. Já em relação ao Casa Verde, notamos que trata-se aí de atendimento modelar na área, tendo avaliação bastante superior. 
Os scores foram os seguintes:

- $\quad$ IPP - 10,55.

- IPUFRJ - 8,85.

- HMRM - 7,35.

- Casa Verde - 18,95.

(Ver figuras 16 e 17)

Figura 16 - Avaliação do valor (capacidade de atração) do segmento laboratório.

\begin{tabular}{|l|c|c|c|}
\hline \multicolumn{4}{|c|}{ Nome do Segmento: Laboratório (especializado em psiquiatria) } \\
\hline \multicolumn{1}{|c|}{ Critérios de Avaliação } & $\begin{array}{c}\text { Peso } \\
\%\end{array}$ & $\begin{array}{c}\text { Nota } \\
0-20\end{array}$ & $\begin{array}{c}\text { Score } \\
(=\mathrm{p} \mathrm{x} \mathrm{n} / 100)\end{array}$ \\
\hline 1. Possibilidade de crescimento & 10 & 15 & 1,50 \\
\hline 2. Intensidade de concorrência & 8 & 18 & 1,44 \\
\hline 3. Investimento (barreiras à entrada) & 6 & 15 & 0,90 \\
\hline $\begin{array}{l}\text { 4. Sinergias (em nível de competências e infra- } \\
\text { estruturas compartilhadas) }\end{array}$ & 15 & 18 & 2,70 \\
\hline 5. Motivação interna & 15 & 10 & 1,50 \\
\hline 6. Possibilidades de parceria externa & 15 & 15 & 2,25 \\
\hline 7. Potencial regional & 10 & 15 & 1,50 \\
\hline 8. Possibilidade de conseguir recursos externos & 6 & 13 & 0,78 \\
\hline $\begin{array}{l}\text { 9. Contribuição para o projeto político geral (e a } \\
\text { imagem do hospital) }\end{array}$ & 15 & 13 & 1,95 \\
\hline Valor do Segmento & 100 & \multicolumn{3}{|c|}{14,52} \\
\hline
\end{tabular}


Figura 17 - Avaliação da posição competitiva do segmento laboratório.

\begin{tabular}{|c|c|c|c|c|c|c|c|c|c|}
\hline \multirow{3}{*}{ Fatores Estratégicos de Êxito } & \multicolumn{5}{|c|}{ Hospital } & \multicolumn{4}{|c|}{ Concorrentes } \\
\hline & \multicolumn{3}{|c|}{ IPP } & \multicolumn{2}{|c|}{ IPUFRJ } & \multicolumn{2}{|c|}{ Casa Verde } & \multicolumn{2}{|c|}{ HMRM } \\
\hline & Peso & Nota & Score & Nota & Score & Nota & Score & Nota & Score \\
\hline $\begin{array}{l}\text { 1. Analisador de bioquímica, } \\
\text { drogas e lítio }\end{array}$ & 15 & 20 & 3,00 & 12 & 1,80 & 18 & 2,70 & 8 & 1,20 \\
\hline $\begin{array}{l}\text { 2. Analisador de hormônios e } \\
\text { imuno-componentes }\end{array}$ & 10 & 0 & 0,00 & 12 & 1,20 & 20 & 2,00 & 15 & 1,50 \\
\hline $\begin{array}{l}\text { 3. Centrífuga preparadora de } \\
\text { líquor }\end{array}$ & 8 & 0 & 0,00 & 0 & 0,00 & 20 & 1,60 & 0 & 0,00 \\
\hline $\begin{array}{l}\text { 4. Profissionais qualificados } \\
\text { (nível médio e superior) }\end{array}$ & 15 & 10 & 1,50 & 5 & 0,75 & 15 & 2,25 & 7 & 1,05 \\
\hline $\begin{array}{l}\text { 5. Abastecimento adequado de } \\
\text { material de consumo }\end{array}$ & 11 & 12 & 1,32 & 20 & 2,20 & 20 & 2,20 & 5 & 0,55 \\
\hline $\begin{array}{l}\text { 6. Renovação contínua do } \\
\text { parque de equipamentos }\end{array}$ & 12 & 10 & 1,20 & 10 & 1,20 & 20 & 2,40 & 5 & 0,60 \\
\hline $\begin{array}{l}\text { 7. Manutenção preventiva e } \\
\text { corretiva do parque de } \\
\text { equipamentos }\end{array}$ & 9 & 17 & 1,53 & 10 & 0,90 & 20 & 1,80 & 5 & 0,45 \\
\hline 8. Parcerias externas & 10 & 10 & 1,00 & 3 & 0,30 & 20 & 2,00 & 15 & 1,50 \\
\hline $\begin{array}{l}\text { 9. Controle de qualidade } \\
\text { permanente (interno e externo) }\end{array}$ & 10 & 10 & 1,00 & 5 & 0,50 & 20 & 2,00 & 5 & 0,50 \\
\hline Score sobre o segmento & 100 & \multicolumn{2}{|c|}{10,55} & \multicolumn{2}{|c|}{8,85} & \multicolumn{2}{|c|}{18,95} & \multicolumn{2}{|c|}{7,35} \\
\hline Posição Relativa & \multicolumn{3}{|c|}{2} & \multicolumn{2}{|c|}{3} & \multicolumn{2}{|c|}{1} & \multicolumn{2}{|c|}{4} \\
\hline
\end{tabular}

Concorrentes: IPUFRJ, Casa Verde, Hospital Municipal Rocha Maia (HMRM).

\section{Segmento 9 - Serviço de Imagem Cerebral (Virtual)}

\section{Análise do valor}

Trata-se de um segmento virtual, pensado como serviço de apoio diagnóstico e terapêutico, não alterando significativamente o projeto político e a imagem do hospital, o que lhe confere nota baixa. Quanto à possibilidade de crescimento, é total: estamos na "Década do Cérebro". Nota máxima.

Não temos nenhum investimento realizado nesse segmento, logo a quantidade de recursos necessária à criação desse serviço teria de ser muito elevada, o que implica nota alta. Sinergias também são grandes com todos os segmentos, o que também implica nota alta.

A motivação interna também é elevada; esse tipo de trabalho implica maior status profissional e maior salário. Nota acima da média. 
Avaliamos, neste segmento, a altíssima possibilidade de parcerias externas, o que justificou sua análise. Nossa localização física acaba nos impelindo a isso, uma vez que estamos situados dentro do campus da UFRJ, com dois Institutos dessa Universidade (Psiquiatria e Neurologia) ao nosso lado apresentando maiores condições de receber investimentos em alta tecnologia. Podemos, no entanto, efetuar trocas importantes com os produtos do laboratório. A nota é alta.

O potencial regional também é elevado. Nota alta. A possibilidade de conseguir recursos externos está ligada aos dois itens anteriores. Nota alta.

Score do segmento: 13,60

\section{Análise da posição competitiva}

Escolhemos, para este segmento, seis fatores estratégicos de êxito:

1. Equipamento de ressonância nuclear magnética (RNM).

2. Mapeador cerebral.

3. Profissionais qualificados.

4. Renovação contínua do parque de equipamentos.

5. Capacitação continuada do conjunto dos profissionais.

6. Acesso a financiamento.

Os pesos dos diversos fatores deste segmento ficaram assim distribuídos: $15 \%$ para os quatros primeiros itens; $20 \%$ para os dois últimos. O IPP recebe nota $0 \mathrm{em}$ todos os itens, pois trata-se de um segmento totalmente virtual.

O IPUFRJ possui um mapeador cerebral, o que lhe dá nota máxima nesse item, porém recebe nota mediana para os itens profissionais qualificados e renovação contínua do parque tecnológico. No fator capacitação continuada do conjunto de profissionais, o IPUFRJ recebe nota reduzida, pois é baixo o seu controle sobre esse fator. $\mathrm{O}$ mesmo ocorre no que se refere ao acesso à fonte de financiamento.

Mais uma vez, convém ressaltar que optamos pela análise desse segmento devido à sua importância crescente no auxílio diagnóstico e no monitoramento terapêutico em psiquiatria. A idéia, no entanto, é desenvolver parcerias com outras instituições a fim de obter acesso a essa tecnologia fundamental.

Os scores foram:

- $\quad$ IPP -0 .

- $\quad$ IPUFRJ -8 .

(Ver figuras 18 e 19) 
Figura 18 - Avaliação do valor (capacidade de atração) do segmento imagem cerebral.

\begin{tabular}{|c|c|c|c|}
\hline \multicolumn{4}{|c|}{ Nome do Segmento: Serviço de Imagem Cerebral (Virtual) } \\
\hline \multirow[t]{2}{*}{ Critérios de Avaliação } & Peso & Nota & Score \\
\hline & $\%$ & $0-20$ & $(=\mathrm{p} \times \mathrm{n} / 100)$ \\
\hline 1. Possibilidade de crescimento & 10 & 20 & 2,00 \\
\hline 2. Intensidade de concorrência & 8 & 10 & 0,80 \\
\hline 3. Investimento (barreiras à entrada) & 6 & 15 & 0,90 \\
\hline $\begin{array}{l}\text { 4. Sinergias (em nível de competências e infra- } \\
\text { estruturas compartilhadas) }\end{array}$ & 15 & 18 & 2,70 \\
\hline 5. Motivação interna & 15 & 12 & 1,80 \\
\hline 6. Possibilidades de parceria externa & 15 & 15 & 2,25 \\
\hline 7. Potencial regional & 10 & 15 & 1,50 \\
\hline 8. Possibilidade de conseguir recursos externos & 6 & 15 & 0,90 \\
\hline $\begin{array}{l}\text { 9. Contribuição para o projeto político geral (e a } \\
\text { imagem do hospital) }\end{array}$ & 15 & 5 & 0,75 \\
\hline Valor do Segmento & 100 & & 13,60 \\
\hline
\end{tabular}

Figura 19 - Avaliação da posição competitiva do segmento imagem cerebral.

\begin{tabular}{|c|c|c|c|c|c|c|c|c|c|}
\hline \multicolumn{10}{|c|}{ Controle dos Fatores Estratégicos de Êxito } \\
\hline \multirow{3}{*}{ Fatores Estratégicos de Êxito } & \multirow{2}{*}{\multicolumn{3}{|c|}{$\begin{array}{c}\text { Hospital } \\
\text { IPP }\end{array}$}} & \multicolumn{6}{|c|}{ Concorrentes } \\
\hline & & & & \multicolumn{2}{|c|}{ IPUFRJ } & \multirow[b]{2}{*}{ Nota } & \multirow[b]{2}{*}{ Score } & \multirow[b]{2}{*}{ Nota } & \multirow[b]{2}{*}{ Score } \\
\hline & Peso & Nota & Score & Nota & Score & & & & \\
\hline $\begin{array}{l}\text { 1. Equipamento de Ressonância } \\
\text { Nuclear Magnética (RNM) }\end{array}$ & 15 & 0 & 0,00 & 0 & 0,00 & & & & \\
\hline 2. Mapeador cerebral & 15 & 0 & 0,00 & 20 & 3,00 & & & & \\
\hline 3. Profissionais qualificados & 15 & 0 & 0,00 & 10 & 1,50 & & & & \\
\hline $\begin{array}{l}\text { 4. Renovação contínua do parque } \\
\text { de equipamentos }\end{array}$ & 15 & 0 & 0,00 & 10 & 1,50 & & & & \\
\hline $\begin{array}{l}\text { 5. Capacitação continuada do } \\
\text { conjunto dos profissionais }\end{array}$ & 20 & 0 & 0,00 & & 1,00 & & & & \\
\hline 6. Acesso a financiamento & 20 & 0 & 0,00 & & 1,00 & & & & \\
\hline Score sobre o segmento & 100 & & & 8 , & & & & & \\
\hline Posição relativa & & 2 & & & & & & & \\
\hline
\end{tabular}

Concorrentes: IPUFRJ. 


\section{O Porta-Fólio de Atividades e a Definição da Estratégia e dos Planos de Desenvolvimento por Segmento}

Apresentamos aqui o porta-fólio do IPP, utilizado para a definição da macroestratégia e dos planos de cada serviço (Figura 20).

Figura 20 - Porta-fólio de atividades - IPP.

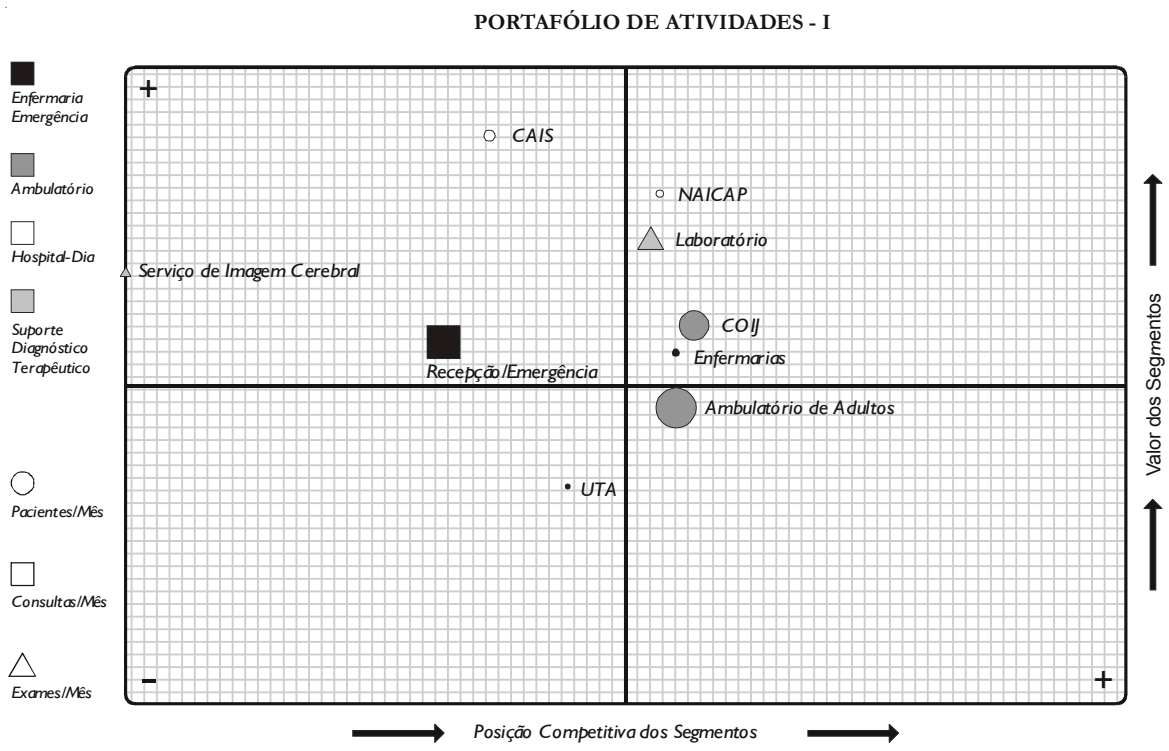

\section{Diretrizes estratégicas (nível macro)}

Não é intenção do IPP desenvolver o segmento de Imagem Cerebral, embora reconheça a importância fundamental desta tecnologia para o presente e, principalmente, para o futuro da psiquiatria. A falta de investimento neste tipo de tecnologia, assim como a necessidade de um alto grau de investimento em equipamentos e recursos humanos para a viabilização deste serviço torna mais razoável que o IPP busque parcerias com as duas instituições universitárias vizinhas (o Instituto de Psiquiatria e o Instituto de Neurologia Deolindo Couto, ambos da UFRJ) a fim de obter acesso a estas novas formas de tecnologia diagnóstica. A proposta de utilização do Laboratório Especializado do IPP por parte do Instituto de Psiquiatria poderia facilitar esta negociação.

A UTA apresenta um valor e uma posição competitiva relativamente desfavoráveis. Este segmento não valoriza o projeto assistencial do Hospital. Reco- 
menda-se negociar com os Hospitais Gerais a transferência de pacientes, reduzir a permanência dos pacientes no hospital ao período exclusivo de desintoxicação, com a rápida transferência do paciente.

O ambulatório de adultos é um segmento de grande volume de atendimento, porém teria pouco valor na medida em que prevalece nele um tipo de atendimento pouco programado, aleatório, sem continuidade e de natureza eminentemente médico-psiquiátrica. Dada a impossibilidade de abrir mão dele, recomenda-se uma estratégia inicial de focalização, que consistiria em aplicar o princípio da base territorial-geográfica atendendo uma população circunscrita à área programática pertinente, e em atender a um quadro nosológico de maior complexidade relativa (retaguarda ambulatorial). Propõe-se, ainda, uma estratégia de diferenciação para este segmento recortado, no sentido de este assumir gradativamente um tipo de modalidade assistencial mais próximo da lógica do hospital-dia, ou seja, um atendimento multidisciplinar, programado, que assegure pelas sinergias necessárias à continuidade do atendimento. A referenciação dos pacientes a equipes de modo a garantir um vínculo ou um atendimento mais personalizado é estimulada.

Cais ou Hospital-Dia de adultos é quase o modelo de atendimento do hospital, apresentando um alto valor, mas uma posição concorrencial desfavorável. A estratégia sugerida é de diferenciação a partir de um investimento e de um conjunto de ações que aumentariam o valor ou a qualidade do atendimento. Esta estratégia supõe incorporar novas formas de atendimento, como o domiciliar, estimular as sinergias internas e a intersetorialidade, melhorar o perfil das equipes etc., de modo a transformar os pontos fracos reconhecidos na matriz dos FCS em objetivos.

O Naicap, com a mesma lógica, só que em uma posição competitiva melhor relativamente, deveria acompanhar a orientação anterior.

Em relação ao laboratório, recomenda-se uma diferenciação maior a partir de um investimento específico, de um controle de qualidade rigoroso e de ações pertinentes. A base da estratégia consistiria em enfrentar os pontos fracos da matriz dos FCS, de modo a avançar em direção a um modelo de laboratório como centro de referência municipal.

Em relação à recepção/emergência, propõe-se recortar o atendimento, através da definição da base territorial deste segmento, e da assunção do mesmo como retaguarda de uma rede de serviços complexos de atenção diária. Sugerem-se medidas que se encaminham no sentido da diferenciação de qualidade, como: restringir o trabalho em regime de plantão (oligoprofissional e descontínuo) apenas àquelas situações inevitáveis, privilegiando o trabalho em equipe interdisciplinar em regime diarista; realizar ações gerenciais e técnicas junto às equipes, explorando acima de tudo o papel estratégico dos profissio- 
nais de enfermagem, tendo em vista acelerar o processo transformador dos modos de atenção às situações de crise e de urgência em saúde mental; melhorar o transporte de pacientes etc.

Restringir a internação apenas àqueles casos que não podem ser enfrentados a partir de um atendimento extra-hospitalar (controle rigoroso das internações); melhorar a sinergia entre a internação e os outros segmentos, a fim de melhor encaminhar e acompanhar o tratamento dos pacientes; estimular rodízios das equipes de internação pelos outros segmentos para estas adquirirem uma visão de conjunto; desenvolver a capacitação necessária à mudança de cultura; garantir supervisão técnica permanente para algumas equipes; estimular a pesquisa etc.

A estratégia geral privilegia a sinergia entre segmentos e a aplicação do principio da base territorial.

A estratégia propõe uma ressegmentação que consistiria na fusão progressiva da recepção/emergência, do ambulatório e do hospital-dia, articulação que redundaria em um macrossegmento equivalente a um Centro de Atenção PsicoSocial Diário, imagem-objetivo do hospital.

\section{Fatores-chave de sucesso e estratégia}

A meta-análise realizada dos FCS permitiu definir os fatores mais importantes do IPP, assim como os fatores mais importantes envolvidos na proposta de ressegmentação dos três segmentos originais: Ambulatório, Cais e Recepção/Emergência, originando o Caps-IPP. O cruzamento dos nove FCS mais importantes do IPP com os 10 fatores que surgem da ressegmentação permitiu selecionar os sete FCS sobre os quais torna-se condição sine qua non trabalhar: equipe multidisciplinar; flexibilidade de resposta à demanda; espaço físico adequado; atendimento domiciliar; base territorial/populacional; integração/parceria com a rede de saúde; necessidade de ações intersetoriais.

$\mathrm{Na}$ maneira como foram propositadamente ordenados, podemos notar que os quatro primeiros fatores (metafatores) acham-se sob controle significativo da Instituição, seja porque esta já realizou importantes investimentos nestes ou porque são fatores sobre os quais a instituição possui razoável autonomia. Por outro lado, os três últimos fatores dizem respeito ao posicionamento da instituição em uma rede de serviços sanitários e sociais, em que a obtenção de controle sobre estes depende de um importante esforço de negociação com os gestores das diversas esferas de governo, com as autoridades das várias áreas sociais de atuação estatal, com os dirigentes de outras unidades de saúde, e finalmente, com a comunidade de usuários e seus familiares. 
Se, a curto prazo, os quatro primeiros oferecem maior facilidade de gerar ações e, por conseguinte, devem ser enfrentados rapidamente e com energia, o resultado a médio e longo prazo das atuações realizadas sobre estes depende, essencialmente, do sucesso na obtenção de resultados importantes nos outros três fatores, os quais acham-se ligados a interatividade da organização com seu entorno comunitário e institucional. Desta forma, se podemos, em um sentido metodológico-estratégico, falarmos em um primeiro e em um segundo tempo, não podemos entendê-los como tempos concretos e seqüenciais, uma vez ser necessário, desde o início, um esforço substancial de ações paralelas sobre os dois grupos de fatores.

\section{Microestratégia: plano de ações por segmento}

\section{Ambulatório de adultos}

- Trabalhar, junto à equipe multiprofissional, as transformações necessárias do modo de atendimento clássico e fragmentado atual para uma atuação cada vez mais interdisciplinar e diversificada, visando a uma aproximação deste segmento com outros segmentos mais dinâmicos e inovadores da instituição. Tais medidas abrem caminho para o processo de ressegmentação proposto na macroestratégia.

- Definir a base territorial/populacional, a fim de ter clareza da demanda a que o novo segmento atenderá.

- Estabelecer um crescente entrosamento com os demais segmentos, através de reuniões, sessões clínicas etc.

- Criar normas e rotinas mínimas (programação), que, associadas a estruturas e ações flexíveis, possibilitarão um atendimento diversificado e individualizado, porém sem desorganizar o serviço.

- Desconcentrar o ambulatório em termos de recursos humanos, distribuindo o trabalho dos técnicos (pelo menos uma parte destes) também pelos outros serviços que deverão participar da ressegmentação proposta na macroestratégia, uma vez que isto constitui um procedimento facilitador deste processo. 


\section{COIJ (ambulatório infanto-juvenil)}

- Trabalhar a integração entre as equipes do COIJ e Naicap para uma futura ressegmentação/fusão destes serviços.

- Definir a base territorial do novo segmento, entendendo que esta deve ser maior do que aquela para outros segmentos/serviços do IPP.

- Negociar junto aos Conselhos de Saúde da AP-2.1 e AP-2.2 e às instituições de saúde da área o Programa de Atenção Integral à Criança.

- Desenvolver ações junto às secretarias Estadual/Municipal de Educação, buscando uma melhor integração com a rede escolar da região.

\section{Cais (hospital-dia de adultos)}

- Discutir com a equipe a ressegmentação do IPP e as estratégias para a construção de um Centro de Atenção Psicossocial que englobe e prolongue o Cais.

- Definir base territorial.

- Desenvolver programas de capacitação, treinamento e educação continuada para a equipe, assim como a utilização de supervisão externa.

- Programar reuniões/seminários com os diversos segmentos a fim de fortalecer a sinergia interna com estes.

- Desenvolver parcerias junto às secretarias de Desenvolvimento Social, Habitação, Trabalho, Esporte e Lazer e Cultura.

- Adequar a estrutura logística (serviço de transporte) e o trabalho da equipe técnica de modo a viabilizar o atendimento domiciliar como ação habitual.

- Promover o máximo de diversidade nas práticas terapêuticas, entendendo que nestas também acham-se incluídas ações terapêuticas informais, o que é fundamental no lidar cotidiano com uma clientela freqüentemente em crise, extremamente diversa e extremamente imprevisível.

\section{Naicap (hospital-dia de crianças)}

- Integrar a equipe deste serviço à do Centro de Orientação Infanto-Juvenil (COIJ), buscando a criação de um único serviço de atenção diária à infância e à adolescência em sofrimento psíquico. 
- Definir claramente sua base territorial.

- Redefinir a forma de segmentação do serviço, utilizando a complexidade e as formas diferenciadas de atenção nele praticadas, ao invés de basear-se no critério de patologia clínica.

- Desenvolver parcerias com as secretarias de Educação e Lazer do município do Rio de Janeiro.

- Estabelecer parcerias com organizações não-governamentais (ONGs) dedicadas à proteção da infância e da juventude.

- Ampliar o acesso a tecnologias de apoio diagnóstico (exames imunológicos, pesquisa de erros inatos do metabolismo, cariótipos e estudos genéticos).

- Instituir maior integração com os demais segmentos do IPP.

- Estabelecer o atendimento domiciliar como ação de rotina.

\section{Enfermarias $A$ e $B$}

- Participar de reuniões, seminários e sessões clínicas, a fim de fortalecer a sinergia com os demais segmentos.

- Redimensionar e aprimorar os serviços de internação, estabelecendo critérios claros e rigorosos para a hospitalização dos clientes, recorrendo a esta apenas quando o tratamento extra-hospitalar mostrar-se inviável para um determinado paciente naquele momento específico de seu tratamento ou de sua vida.

- Utilizar a internação como um instrumento terapêutico de exceção, o que deve refletir-se em tempos de permanência curtos.

- Desenvolver com maior empenho ações terapêuticas no sentido da integração social do paciente após sua internação, oferecendo a ele recursos semelhantes aos existentes em outros segmentos da Instituição que trabalham com reabilitação psicossocial.

- Interligar o trabalho das enfermarias entre si e destas com o Ambulatório e o Cais, a fim de melhor encaminhar e acompanhar o tratamento dos pacientes.

- Desenvolver programas de capacitação, treinamento e educação continuada da equipe técnica de enfermagem, propiciando a esta mecanismos facilitadores da compreensão da missão do IPP e torná-la parte integrante e fundamental do processo de mudanças da cultura institucional.

- Viabilizar estudos sobre os possíveis danos à saúde física e mental dos técnicos de enfermagem e suas causas, já que estes profissionais estão mais 
expostos a um contato intenso e intensivo com os pacientes em crise. Cuidar da saúde destes profissionais significa também cuidar da saúde dos pacientes sob os seus cuidados, pois o contato entre profissionais e pacientes é intenso e contínuo.

- Estimular a participação da equipe de enfermagem em todos os projetos e programas dos diversos segmentos do IPP que possam se beneficiar das ações de enfermagem (Ex: rodízio da equipe de enfermagem por estes segmentos), sendo esta constante participação uma forma de treinamento em serviço para estes profissionais.

- Garantir a supervisão técnica nas 24 horas para a equipe de enfermagem.

- Integrar as equipes especializadas das enfermarias com a área de pesquisa, visando o estudo aprofundado de vários assuntos de relevância, como, por exemplo, as especificidades do adoecer psíquico da mulher.

\section{Unidade de Tratamento de Alcoolistas (UTA)}

Negociar, junto à Secretaria Municipal de Saúde:

- A oferta de leitos clínicos na rede de saúde para pacientes alcoolistas que demandam atendimento médico hospitalar (incluindo desintoxicação).

- A criação de uma rede de serviços especializados no atendimento diário ao alcoolismo: Day Clinics.

- A participação do IPP na criação desses serviços especializados, contribuindo com os profissionais altamente qualificados e experientes no assunto que possui, tanto na composição das equipes quanto em atividades de supervisão e consultoria.

- A manutenção no IPP da internação daqueles pacientes que, além do alcoolismo, manifestam quadros psiquiátricos primários agudos.

- $\mathrm{O}$ apoio a iniciativas não-governamentais, sem fins lucrativos, que tenham como objetivo o auxílio e o tratamento de pacientes alcoolistas.

\section{Recepção e emergência}

- Investir intensamente em ações gerenciais e técnicas junto à equipe que realiza os atendimentos de recepção e emergência, a fim de acelerar o processo transformador dos modos de atenção às situações de crises e urgências em saúde mental. Neste caso, deve-se dar uma ênfase especial aos profissionais de enfermagem, tendo em vista o papel estratégico destes dentro da equipe técnica em geral. 
- Definir claramente a base territorial deste segmento, a partir de negociações com as instâncias governamentais competentes.

- Manter fóruns permanentes de discussão com as demais unidades que realizam atendimentos de recepção e emergência em saúde mental no município do Rio de Janeiro.

- Restringir o trabalho em regime de plantão (oligoprofissional e descontínuo) apenas àquelas situações inevitáveis, privilegiando o trabalho interdisciplinar em regime diarista.

- Adequar o Serviço de Recepção e Emergência para que, gradualmente, passe a ocupar um papel de retaguarda para uma rede de serviços complexos de atenção diária.

- Prover este segmento com os meios adequados para o transporte de pacientes, de modo a assegurar a remoção segura de usuários para outros hospitais, serviços de saúde mental ou domicílios sempre que indicado.

- Garantir o acesso contínuo, durante as 24 horas do dia, a serviços de apoio diagnóstico e terapêutico.

- Garantir supervisão técnica, nas 24 horas, para a equipe de enfermagem.

- Articular formas de controle e acompanhamento das internações involuntárias junto às instâncias governamentais, às associações de usuários e familiares, aos diversos conselhos de classe, aos conselhos municipal e distritais e aos órgãos judiciais competentes.

\section{Laboratório (especializado em psiquiatria)}

- Prosseguir o desenvolvimento do laboratório do IPP no sentido de consolidá-lo como centro de referência no campo da saúde mental, especializado no diagnóstico diferencial (rotinas e algoritmos diagnósticos específicos) e na biossegurança (monitoramento de drogas e prevenção e diagnóstico de síndromes iatrogênicas) de pacientes em tratamento psiquiátrico.

- Negociar, junto às instâncias governamentais competentes, o papel do Laboratório do IPP como centro de referência para toda a rede de saúde mental no município do Rio de Janeiro.

- Adquirir, através de comodato (forma mais econômica e que permite maior agilidade em termos de renovação tecnológica), equipamento analisador de hormônios e imunocomponentes, assim como centrífuga preparadora de líquor. Tais equipamentos tornariam o laboratório, de fato, plenamente capacitado a satisfazer seu papel de referência. 
- Instituir controle de qualidade externo e aprimorar os já existentes mecanismos internos de avaliação de qualidade.

- Negociar a reposição e complementação dos recursos humanos necessários (nível médio e superior) junto às instâncias governamentais competentes e junto às demais unidades de saúde mental no município do Rio de Janeiro.

- Desenvolver capacitação e treinamento continuado para todos os profissionais do laboratório.

- Aprimorar o processo de abastecimento de material de consumo do laboratório.

- Estender a atuação do laboratório ao período de 24 horas e a todos os dias da semana.

\section{A Mandala Territorial}

O conceito de mandala territorial (Figura 21), inspirado na conhecida imagem budista tibetana, trata-se de uma invenção do grupo para ilustrar, graficamente, as várias formas e amplitudes distintas de inserção do IPP em uma rede de saúde mental no município do Rio de Janeiro.

A idéia central é a de que, sendo o IPP uma organização profissional complexa e de produtos múltiplos, sua inserção na rede também deva ser diversa e múltipla. O IPP, além dos diversos modos e níveis de atenção em saúde mental (aspecto que destacamos neste trabalho), produz também ações e projetos nas áreas de ensino (programas de residência e estágios curriculares), intervenção cultural (produção de vídeos/TV-Pinel, eventos culturais em espaços públicos), assessoria em organizações de serviços e políticas de saúde mental, e atividades intersetoriais de reabilitação psicossocial (Cooperativa da Praia Vermelha, Clube da Esquina, Projeto Lar Abrigado).

O núcleo da mandala é, precisamente, o Centro de Atenção Diária (Caps-IPP) que constitui o eixo assistencial em torno do qual gira a Instituição e através do qual o IPP se conecta mais profundamente à rede de saúde mental. De todo o IPP, o Caps é o que tem menor (embora significativa) base territorial, pois trata-se de um Caps entre outros existentes na sub-rede local à qual pertence. Estes em conjunto, por sua vez, devem dar cobertura integral e flexível em saúde mental a toda a população de sua área de referência, isto nos dias úteis e no horário normal de expediente. Cada Caps é responsável por uma fração definida desta comunidade.

Se o Caps-IPP tem a menor base territorial de toda a Instituição, é nele em que a vinculação do Instituto com seu entorno comunitário se dá de forma mais intensa, duradoura e solidária. 
Em um segundo nível, o IPP pode perfeitamente oferecer retaguarda para atendimentos de emergência nos períodos noturnos, nos fins-de-semana e feriados, assim como para internações eventuais, a toda a área de referência da rede local de Caps.

Um terceiro nível seria o de exames laboratoriais dirigidos às necessidades de uma clientela com problemas mentais (diagnósticos diferenciais, biossegurança). Neste aspecto, o Laboratório do IPP tem acumulado um alto nível de especialização e de capacitação na área. Tendo em vista o elevado nível de tecnologia especializada e automação atingido pelo laboratório do IPP, este poderia seguramente ter, como área de abrangência (base territorial), toda a rede de saúde mental do município do Rio de Janeiro.

Por fim, um quarto e último nível de atuação, agora já ultrapassando os limites do recorte assistencial, diz respeito às já citadas áreas de ensino, pesquisa e assessoria, entre outras, as quais não necessitam restringir suas ações ao distrito local ou ao município, podendo produzir ações em nível estadual e federal.

Há, portanto, uma relação inversa entre a amplitude da base territorial e o nível de vinculação estabelecido entre a Instituição e seus usuários. Um paciente psicótico grave tratado no Caps do IPP necessita de um tipo de vinculação em termos de tempo, espaço e relação pessoal que um aluno de residência do IPP proveniente de Manaus, por exemplo, pode e deve dispensar ao final de seu período de formação. Este último, ao retornar à sua cidade natal, poderá cumprir o papel importantíssimo de agente multiplicador dos novos saberes e práticas terapêuticas aprendidas, tarefa indispensável ao avanço do processo de reforma psiquiátrica no país.

Como última observação, cabe destacar que, dentro do simbolismo gráfico da mandala, as formas circulares referem-se sempre a atividades assistenciais, ao passo que o quadrado exterior contém as outras importantes ações executadas por esta instituição complexa chamada Instituto Philippe Pinel. 
Figura 21 - Mandala Territorial do Instituto Philippe Pinel (macroestratégia em rede).

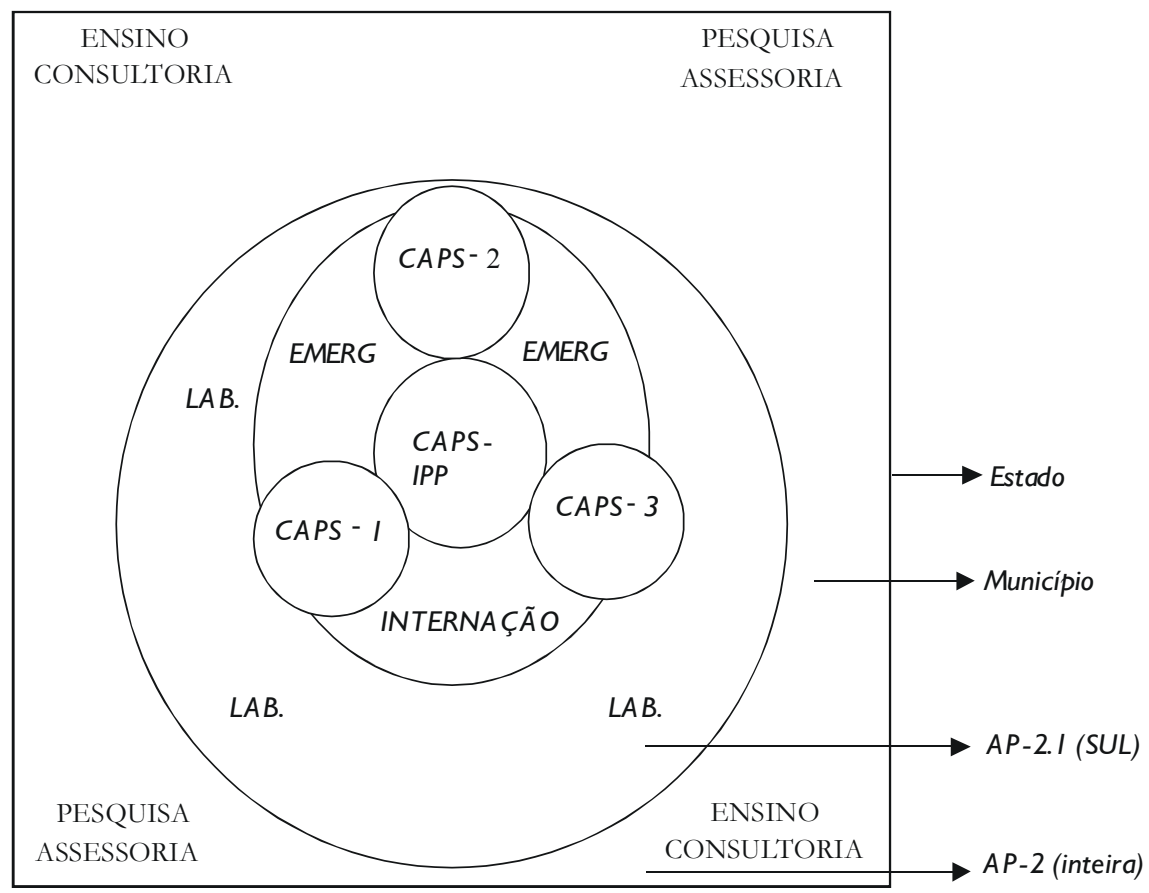

\section{Conclusões}

Não é tarefa simples realizar o fechamento de um trabalho como este, com um verdadeiro manancial de dados a serem analisados e de possibilidades na aplicação dos resultados obtidos. Em função disto, deixamos de lado a pretensão de esgotar todas as possibilidades e decidimos nos concentrar em algumas que consideramos mais importantes para o momento vivido pela Instituição, o qual mostra-se repleto de desafios:

- Completar as modificações organizacionais necessárias à adequação plena das ações institucionais ao ideário da reforma psiquiátrica incluído em sua missão e diretrizes básicas.

- Modernizar gerencialmente a Instituição para que esta possa não apenas responder às novas exigências de funcionamento em rede e de adaptação a novos modelos de gestão mas, sobretudo, para que possa melhorar a eficácia e a eficiência de suas ações atuais. 
- Consolidar o papel da Instituição como liderança importante no processo de reforma psiquiátrica em andamento no país (uma das reformas mais avançadas do mundo).

Em parte, tentamos responder sinteticamente a esses desafios com nossa macroestratégia de criação de um Centro de Atenção Diária no Instituto (CapsIPP), porém conscientes de que ainda há muito por fazer em termos de ações concretas - políticas, gerenciais e técnicas - para chegarmos à implementação bem-sucedida desta proposta. Sabemos que a proposta é boa, mas também entendemos que sua implementação irá requerer importante trabalho gerencial na Instituição, de forma a obter a adesão do corpo institucional a essa estratégia.

Este trabalho deixa à mostra várias pontas de fio que ainda podem ser puxadas do novelo de informações que produziu. Esperamos que a Instituição possa utilizá-las e desenvolvê-las no processo contínuo de aperfeiçoamento de suas ações.

Por outro lado, reconhecemos que há aspectos do trabalho, principalmente os que se referem ao desenvolvimento do método da démarche, contidos na metaanálise, nos exercícios projetivos e nas inovações gráficas (não apresentados aqui), que merecem um tratamento especial e detalhado que não caberia ser feito no âmbito deste trabalho. No entanto, esse detalhamento deve, necessariamente, ser realizado em trabalho específico. 



\section{ANÁLISE ESTRATÉGICA E PROSPECTIVA EM SAÚDE: o enfoque de Godet e simulações de cenários para o Programa de Saúde da Família (PSF)}

Francisco Javier Uribe Rivera

Desde o século XVI, o termo prospectiva (relançado por Gaston Berger em 1957) corresponde ao ato de olhar para longe, de discernir alguma coisa que está à nossa frente (Godet, 1993). Entende-se aqui a construção de cenários como o ramo mais formalizado da Prospectiva, por escorar-se em métodos e técnicas de análise do futuro.

O conceito de cenário foi criado, na década de 60, pela Rand Corporation e popularizado por Herman Khan (1969) em seus trabalhos pioneiros no campo militar e da segurança nacional, estendendo-se mais tarde à política.

A palavra cenário provém do teatro. Significa a criação de um entorno adequado e pertinente para representar ou situar uma obra. Indica o lugar e as circunstâncias em que se desenvolve o tema. O tema é o texto e o cenário é o contexto que o determina. Algo semelhante ocorre com o plano. O conteúdo propositivo do plano é o texto, mas esse texto é ambíguo sem as condições explícitas de seu contexto ou cenário. Assim, o cenário é o conjunto de condições e pressupostos em que se situa o plano (Matus, 1994).

O enfoque de cenários se desenvolve simultaneamente nos Estados Unidos e na França, caminhando para um certo consenso metodológico. Investigadores norteamericanos como Gordon, Elmer e Dalkey desenvolvem vários métodos relativamente formalizados de construção de cenários, baseados, na sua maioria, em reuniões de peritos: Delphi, matrizes de impactos cruzados etc.(Godet, 1993). O método dos impactos cruzados foi idealizado originalmente por Gordon, no Instituto para o Futuro (Roubelat, 1993), e posteriormente utilizados pelos franceses. Na França, os trabalhos pertinentes recebem a influência do grande pensador estratégico Michel Godet e se materializam inicialmente em estudos de prospectiva geográfica implementados pela Delegação para o Ordenamento do Território e a Ação Regional (Datar). 
O objetivo geral da técnica de cenários é, segundo Schwartz (2000), permitir a formulação de planos para todas as alternativas de futuro possíveis ou imaginadas, ou seja, ampliar as possibilidades de intervenção, tendo como referentes vários cenários alternativos.

Objetiva-se, aqui, apresentar a metodologia de Godet, com as adaptações promovidas por nós, introduzindo também a lógica do software de probabilização de cenários que compõe o método original: o SMIC Prob-Expert, na sua versão revisada de 1998. Para dar exemplos sobre a aplicação da metodologia, apresentamos algumas simulações do cenário do Programa de Saúde da Família (PSF), desenvolvidas por várias turmas de alunos do curso de Planejamento de Saúde do Mestrado de Saúde Pública da Ensp. Discorremos, ainda, sobre a utilidade da técnica de cenários segundo outros enfoques, especialmente o da aprendizagem organizacional.

\section{Algumas Definições Teóricas Prévias à Apresentação do Enfoque}

\section{Várias definições de cenário}

- Um olhar sobre o futuro orientado a esclarecer, iluminar a ação presente (Godet, 1985).

- A descrição das características essenciais (no sentido que elas afetam as alternativas estratégicas adotadas) do contexto futuro dentro do qual estas alternativas deverão ser implementadas (Quade,1993).

- A prospectiva é um panorama dos futuros possíveis de um sistema destinado a iluminar as conseqüências das estratégias de ação projetadas.

- Conjunto coerente formado pela descrição de uma situação futura e do caminho que permite passar da situação original à situação futura.

- Configuração de imagens de futuro com base em jogos coerentes de hipóteses em relação às variáveis centrais do objeto de análise e de seu ambiente e das estratégias e alianças dos atores (Buarque, 1993).

\section{Objetivos da construção de cenários}

- Escolher, entre a infinidade de combinações de hipóteses projetadas, um pequeno número, que apresenta o mais alto grau de coerência, de verossi- 
milhança, e, acima de tudo, de interesse para esclarecer as decisões a tomar (Araújo, 1984) (École Nationale de Santé Publique/França, 1997).

- Ajudar a situar, a escolher o tipo de plano ou de ação estratégica mais adequados.

\section{Tipos de cenários (Hatem et al., 1993)}

- Normativos (backcasting): parte-se do ponto de chegada para reconstituir o caminho ou a trajetória que é necessário seguir desde a situação presente (de um futuro normativo para o presente).

- Exploratórios (forecasting): exploração das trajetórias possíveis do presente para o futuro.

- Literários: sem formalismo lógico, qualitativos.

- Formalizados: aplicação de métodos matemáticos (cálculo de probabilidades).

- Sem surpresa: não supõem rupturas significativas em nenhum domínio e têm uma probabilidade subjetiva bastante elevada.

- Contrastados: exploram as conseqüências de uma ruptura importante, de probabilidade eventualmente baixa, mas com impacto potencialmente importante.

O enfoque que apresentamos aqui é um enfoque combinado, que conjuga um tipo de análise estratégica qualitativa, baseada no jogo dos atores, e uma análise formalizada, que supõe o cálculo das probabilidades dos cenários, a partir da definição das probabilidades isoladas e condicionais (cruzadas) das hipóteses de comportamento das variáveis-chave do sistema em análise. Este enfoque permite, por outro lado, a construção de cenários exploratórios associada a um esforço de backeasting posterior.

O núcleo básico do enfoque está definido pela análise estratégica de atores vis-à-vis as variáveis do sistema e pelo método dos impactos cruzados, consubstanciado no software pertinente, que permite cruzar as hipóteses de comportamento de um sistema em processo de prospeção, probabilizando suas relações recíprocas ou combinações. 


\section{Síntese do Enfoque Formalizado de Previsão de Cenários de Godet (adaptado)}

O método compreende os seguintes procedimentos concatenados:

\section{Delimitação do sistema ou do domínio problemático}

Definição do assunto, da área, da organização ou do problema que se pretende investigar.

Identificação das variáveis externas e internas do sistema (até 15) e
redução de variedade

A primeira questão que se coloca quando se deseja explorar o elenco dos futuros possíveis é identificar os elementos fundamentais para o futuro da organização/situação estudada, os quais terão de ser hierarquizados por motivos operacionais.

O principal método de redução preconizado corresponde à análise estrutural (Roubelat, 1993; Bourse, 1992; Jouvenel, 1993) que consiste em analisar, através de um quadro de dupla entrada, a influência que cada variável exerce sobre as outras, ${ }^{1}$ ponderada em termos de nenhuma (0), baixa (1), média (2) e alta (3) intensidade. $\mathrm{O}$ quadro da análise estrutural (Figura 1) permite estabelecer a distinção entre variáveis internas e externas. Este tipo de análise possibilita detectar o grau de determinação e de dependência das variáveis entre si. As variáveis de maior poder de determinação (em termos do número de variáveis que influenciam e da intensidade do impacto) são as variáveis motrizes, cuja evolução futura marcará de maneira decisiva o sistema global. Além das variáveis predominantemente motrizes, adquirem uma grande importância para a construção de cenários as variáveis de ligação, que apresentam simultaneamente uma alta motricidade e um alto nível de dependência, ou seja, contribuem para determinar um bom número de outras variáveis e são, simultaneamente, determinadas por um bom número de outras. Estas últimas são consideradas dimensões de incerteza particularmente significativas.

Como a matriz de análise estrutural de base permite detectar apenas as relações diretas entre variáveis, mas não as indiretas, o método sugere a utilização de um procedimento matemático que consiste em multiplicar a matriz de base por ela mesma, tantas vezes quanto necessário, até que a hierarquia das variáveis alcance uma estabilidade (em geral a partir de M7 ou M8). Assim, uma relação de ordem 2 entre A e B significa que A exerce uma influência sobre uma terceira componente $C$, que, por sua vez, atua sobre B. 
As variáveis de ligação corresponderiam às "incertezas críticas", por oposição aos "elementos predeterminados", que seriam variáveis de alta predição ou de progressão lenta ou conhecida. A escolha das variáveis-chave do cenário implica hierarquizar as próprias variáveis sistêmicas motrizes, privilegiando umas poucas incertezas críticas, que estabelecerão a diferença entre os cenários, pois os elementos predeterminados tendem a comportar-se de maneira homogênea nos vários cenários, devendo, portanto, ser secundarizados (Schwartz, 2000).

Isto corresponde a privilegiar como variáveis-chave aquelas que têm um alto impacto sobre o sistema prospectado e um alto nível de incerteza (Grupo Artur D. Little; 2002).

Figura 1 - Matriz de análise estrutural.

\begin{tabular}{|c|c|c|c|c|c|}
\hline \multirow{2}{*}{ Ação de/sobre } & \multicolumn{2}{|c|}{ Variáveis Internas } & \multicolumn{2}{c|}{ Variáveis Externas } & Total Linhas \\
\cline { 2 - 6 } & $\mathrm{A}$ & $\mathrm{B}$ & $\mathrm{C}$ & $\mathrm{D}$ & \\
\hline A & 0 & 3 & 2 & 3 & 8 \\
\hline B & 1 & 0 & 1 & 1 & 3 \\
\hline C & 0 & 2 & 0 & 1 & 3 \\
\hline D & 0 & 1 & 0 & 0 & 1 \\
\hline Total Colunas & 1 & 6 & 3 & 5 & \\
\hline
\end{tabular}

Fonte: Rivera, 2003.

Nesta matriz de análise estrutural, o resultado observado no total das linhas mostra a influência de uma variável sobre as outras (grau de determinação ou motricidade). Já, pelo resultado no total das colunas, pode-se avaliar o quanto uma variável é influenciada por outras (grau de dependência). Observa-se que a variável A apresenta uma maior motricidade, e a variável B, uma maior dependência. A variável D apresenta uma baixíssima motricidade e uma alta dependência. Estas últimas variáveis praticamente poderiam ser descartadas para a análise do cenário respectivo por serem mais resultados do que causas ou forças motrizes.

Os valores da análise estrutural podem ser expressos em um gráfico influência/dependência do seguinte tipo (Gráfico 1): 
Gráfico 1 - Grau de motricidade e dependência das variáveis do sistema.

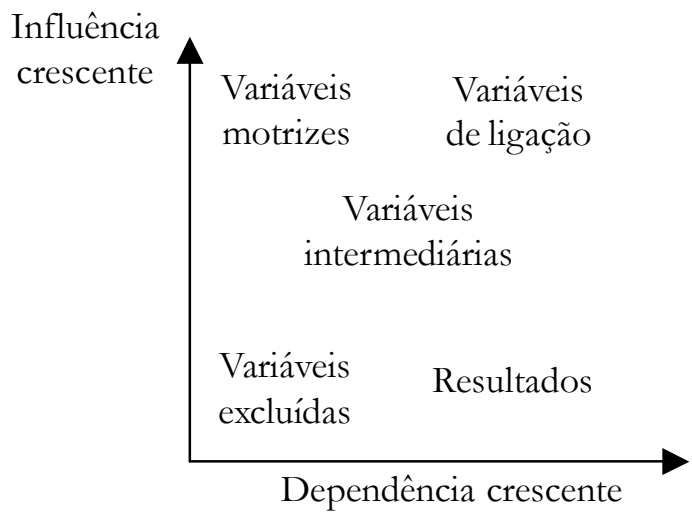

Fonte: Godet, 1993.

Em função da distribuição das variáveis, o sistema pode ser classificado como estável ou instável (Gráfico 2).

Gráfico 2 - Dois tipos de distribuição das variáveis.

entradas

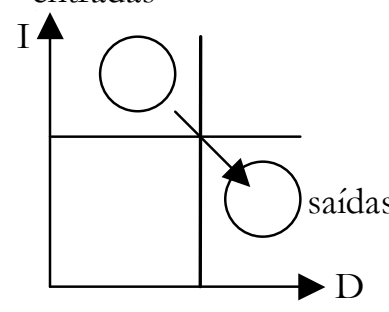

Sistema estável

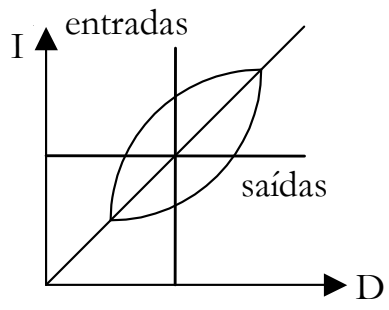

Sistema instável

Fonte: Godet, 1993.

No caso de um sistema estável, há um predomínio das variáveis motrizes. Se predominam as internas ou dominadas pela organização, poder-se-ia pensar em uma forma de atuação bastante próxima ao planejamento tradicional em universo de risco, após a construção de alguns cenários sobre o ambiente.

No caso de um sistema instável, há um predomínio das variáveis de ligação. Este caso estaria, em geral, associado a uma reflexão em termos do jogo dos atores, pois a dialética dos atores envolvidos seria determinante na construção dos cenários. 
Porém, se os desafios são, na sua maioria, externos, a análise prospectiva em termos do jogo dos atores é delicada e deve dar lugar ao estabelecimento de um sistema de vigilância prospectiva compartilhado. Às vezes, a posição extremamente dependente dos fatores típicos da organização leva à necessidade de ampliar a reflexão para outras organizações.

Dito de uma maneira mais genérica, as características do sistema e a posição no gráfico influência/dependência dos fatores internos e externos permitiriam orientar a escolha dos instrumentos de análise e de construção dos cenários.

O resultado da análise estrutural é reduzir de maneira notável a variedade da informação inicial, excluindo da análise posterior uma série de variáveis. Considera-se que o elenco de variáveis escolhidas nesta fase representaria o elenco quase definitivo das variáveis-chave ou das forças motrizes do cenário.

Mas, a análise estrutural isolada é uma análise desencarnada, sem vida. Torna-se necessário, portanto, entrar numa fase mais explicativa das variáveis, que leve em conta sua evolução ao longo do tempo e os atores nela envolvidos. Esta fase consiste em uma análise retrospectiva e presente das variáveis selecionadas, procurando identificar as tendências pesadas (variáveis que têm um comportamento bastante previsível, de mudanças lentas), as tendências insinuantes ou fatos geradores de futuro (variáveis que, não sendo tão decisivas atualmente, insinuam uma importância crescente no futuro) e o jogo dos atores (Hatem et al., 1993; Bourse, 1992; Jouvenel, 1993).

\section{A Análise dos atores, de suas estratégias em face das variáveis- chave e a formulação dos eventos possíveis}

A análise do jogo dos atores é extremamente importante para a simulação do comportamento futuro das variáveis-chave. Nesta fase, procede-se à exploração das estratégias dos atores vis-à-vis as variáveis do sistema, para a partir daí definir as principais tendências possíveis. A seguir será necessário escolher, entre as várias tendências possíveis de cada variável-chave, as tendências centrais, ou seja, as hipóteses de comportamento futuro de maior probabilidade de ocorrência ou simplesmente os eventos centrais.

Godet (1993) preconiza identificar até cinco atores suscetíveis de influenciar as variáveis pré-selecionadas, explorando seus projetos ou suas estratégias de influência no sistema-objeto e suas relações de influência recíproca, em termos de poder. Em relação a esta sugestão da escolha dos atores realmente mais relevantes, pensamos que o número de cinco deve ser visto com flexibilidade, porém é válida a mensagem no sentido de reduzir a variedade o máximo possível, para tornar o processo mais operacional. 
O modelo de análise dos atores de Godet, intitulado modelo MACTOR, está baseado no tratamento informatizado da informação considerada necessária. Neste modelo, o autor procura sistematizar os enfoques de teoria dos jogos ou do Conflict Analysis desenvolvido por Frazer e Hippel (1986, apud Godet, 1993).

Preferimos fazer uma adaptação qualitativa desse modelo, incorporando o raciocínio e algumas ferramentas do modelo de análise estratégica do Planejamento Estratégico-Situacional de Matus (1994).

Duas matrizes de cálculo nos parecem extremamente úteis: a) uma matriz que revelaria o poder de influência, o grau de controle ou a governabilidade dos atores sobre as variáveis mais determinantes, ponderando esse controle em termos de alto (A), médio (M), baixo (B) e nenhum controle (0) (Figura 2); b) uma matriz que incluiria as estratégias de atuação potenciais (posição) dos atores de maior governabilidade sobre as variáveis-chave já selecionadas, considerando a informação da análise estrutural (as outras variáveis que atuam sobre cada variável), e as principais possibilidades de comportamento das mesmas em função da posição dos atores (objetivos possivelmente associados ao quadro das estratégias) (Figura 3).

Figura 2 - Matriz de influência dos atores/variáveis determinantes.

\begin{tabular}{|c|c|c|c|c|}
\hline & V 1 & V2 & V3 & V4 \\
\hline Ator 1 & 0 & B & A & M \\
\hline Ator 2 & B & A & M & 0 \\
\hline Ator 3 & A & 0 & M & A \\
\hline
\end{tabular}

A matriz do controle das variáveis pelos atores (a) nos ensejaria uma idéia da governabilidade que os atores teriam sobre as variáveis, de modo a podermos circunscrever os atores de maior poder de influência sobre o comportamento futuro de cada variável. Este comportamento dependeria do jogo interativo dos projetos ou das estratégias dos atores respectivos. 
Figura 3 - Matriz das estratégias dos atores e dos objetivos possíveis pertinentes à variável $\mathrm{x}$.

\begin{tabular}{|c|c|c|c|}
\hline Atores & $\begin{array}{l}\text { Variáveis } \\
\text { influentes }\end{array}$ & Estratégias de atuação & $\begin{array}{c}\text { Tendências ou } \\
\text { objetivos possíveis }\end{array}$ \\
\hline \multirow[t]{3}{*}{ A1 } & V1 & & \multirow{6}{*}{$\begin{array}{l}\text { a) } \\
\text { b) } \\
\text { c) }\end{array}$} \\
\hline & V2 & & \\
\hline & V3 & & \\
\hline \multirow[t]{3}{*}{ A2 } & V1 & & \\
\hline & $\mathrm{V} 2$ & & \\
\hline & V3 & & \\
\hline
\end{tabular}

A matriz das estratégias possíveis e dos objetivos para cada variávelchave (b) permitiria relacionar ou narrar as estratégias de atuação potencial dos atores de maior governabilidade e deduzir das mesmas as possibilidades de comportamento possível de cada variável. A distinção dos comportamentos futuros pertinentes a cada variável suporia um cálculo estratégico mais rigoroso nos casos das variáveis controladas por atores divergentes. Para definição dessas tendências, pode ser de utilidade explorar alguma variante da análise das relações de influência entre os atores ( 2 a 2), preconizada por Godet (1993), ou realizar um balanço das relações de poder ou de força inerentes a esses atores, na linha do PES. Pode ser útil também para distinção das tendências mais prováveis o uso da lógica da matriz de motivação do momento estratégico do PES. Neste caso, seria registrada a motivação dos diferentes atores (independente da governabilidade) em face dos objetivos associados a cada variável, correspondendo os objetivos associados às tendências ou aos eventos mais prováveis em função das estratégias identificadas para os atores de maior governabilidade.

$\mathrm{Na}$ simulação das estratégias, a consulta aos atores ou a conhecedores dos mesmos é fortemente recomendada. Às vezes, os atores não falam de suas estratégias, mas falam das estratégias dos outros. Por superposição de informações, pode-se montar um quadro bastante aproximado das estratégias.

Uma variação bastante interessante da matriz das estratégias dos atores diante das variáveis do sistema foi confeccionada em sala de aula no mestrado de Saúde Pública da Escola Nacional de Saúde Pública da Fiocruz (Ensp/ Fiocruz, turma 2001). Refere-se à análise das estratégias dos atores diante das variáveis-chave do Programa de Saúde da Família (PSF) e inclui algumas tendências (Figura 4). 
Figura 4 - Estratégias dos atores vis-à-vis as variáveis-chave do PSF e os principais eventos simulados.

\begin{tabular}{|c|c|c|c|c|c|c|}
\hline $\begin{array}{l}\text { Atores/ } \\
\text { Variáveis }\end{array}$ & $\begin{array}{l}\text { V1: Finan- } \\
\text { ciamento }\end{array}$ & $\begin{array}{l}\text { V2:Formação } \\
\text { Profissional }\end{array}$ & $\begin{array}{l}\text { V3: Fixação } \\
\text { Profissional }\end{array}$ & V4: Flexibilidade & V5: Gestão & $\begin{array}{l}\text { V6: Controle } \\
\text { Social }\end{array}$ \\
\hline MS & $\begin{array}{l}\text { Aumento no } \\
\text { investimento } \\
\text { diferenciado }\end{array}$ & $\begin{array}{l}\text { Ampliação do } \\
\text { mercado de } \\
\text { trabalho. } \\
\text { Produção de } \\
\text { material } \\
\text { educativo }\end{array}$ & $\begin{array}{l}\text { Manutenção da } \\
\text { remuneração } \\
\text { diferenciada } \\
\text { Programa de } \\
\text { Interiorização } \\
\text { do Trabalhador } \\
\text { em Saúde (Pits) }\end{array}$ & $\begin{array}{l}\text { Estabelecer } \\
\text { critérios para } \\
\text { flexibilização e } \\
\text { integração do } \\
\text { PFF }\end{array}$ & $\begin{array}{l}\text { Avaliação da } \\
\text { produção }\end{array}$ & \\
\hline Conasems & $\begin{array}{l}\text { Mudanças nas } \\
\text { regras de fi- } \\
\text { nanciamento } \\
\text { com vistas à } \\
\text { eqüidade }\end{array}$ & & & $\begin{array}{l}\text { Implementação } \\
\text { da Noas com } \\
\text { vistas a melhorar } \\
\text { a referência e } \\
\text { contra-referência } \\
\text { e realidades } \\
\text { regionais }\end{array}$ & & \\
\hline Conass & Idem Conasems & & & & & \\
\hline SMS & $\begin{array}{l}\text { Plano } \\
\text { municipal } \\
\text { priorizando o } \\
\text { PSF }\end{array}$ & & $\begin{array}{l}\text { Melhora das } \\
\text { condições de } \\
\text { trabalho./ Su- } \\
\text { porte da rede de } \\
\text { serviços } \\
\text { /Continuidade } \\
\text { dos contratos } \\
\text { temporários } \\
\end{array}$ & & $\begin{array}{l}\text { Avaliação dos } \\
\text { resultados } \\
\text { Melhorar e } \\
\text { integrar o SIS }\end{array}$ & $\begin{array}{l}\text { Atender } \\
\text { reivindicações } \\
\text { do CMS }\end{array}$ \\
\hline Pólos & & $\begin{array}{l}\text { Ampliação } \\
\text { dos pólos de } \\
\text { capacitação e } \\
\text { do número de } \\
\text { profissionais } \\
\text { capacitados. } \\
\text { Manutenção } \\
\text { da educação } \\
\text { continuada }\end{array}$ & & & & \\
\hline CMS & & & & & & $\begin{array}{l}\text { Fiscalizar a } \\
\text { qualidade do } \\
\text { serviço }\end{array}$ \\
\hline $\begin{array}{l}\text { Evento } \\
\text { Central }\end{array}$ & $\begin{array}{l}\text { Aumento do } \\
\text { volume de } \\
\text { financiamento } \\
\text { com recursos } \\
\text { próprios dos } \\
\text { estados e } \\
\text { municípios } \\
(\mathrm{EC} / 29) \text {. } \\
\text { Aumento do } \\
\text { investimento do } \\
\text { MS tendo em } \\
\text { vista a eqüidade }\end{array}$ & $\begin{array}{l}\text { Aumento do } \\
\text { número de } \\
\text { profissionais } \\
\text { capacitados } \\
\text { para o PSF }\end{array}$ & $\begin{array}{l}\text { Dificuldade de } \\
\text { fixação do } \\
\text { profissional em } \\
\text { regiões } \\
\text { desenvolvidas } \\
\text { por causa dos } \\
\text { contratos de } \\
\text { trabalho } \\
\text { temporários, } \\
\text { apesar da } \\
\text { melhora das } \\
\text { condições de } \\
\text { trabalho }\end{array}$ & $\begin{array}{l}\text { Implementação } \\
\text { dos papéis } \\
\text { definidos pela } \\
\text { Noas nos três } \\
\text { níveis de governo } \\
\text { e estabelecimento } \\
\text { de interfaces com } \\
\text { outros programas }\end{array}$ & $\begin{array}{l}\text { Manutenção dos } \\
\text { sistemas de } \\
\text { planejamento/ } \\
\text { gestão } \\
\text { incorporados pela } \\
\text { Noas } \\
\text { (PPI....), aplicados } \\
\text { com limitações }\end{array}$ & $\begin{array}{l}\text { Aumento da } \\
\text { participação dos } \\
\text { conselhos na } \\
\text { implementação } \\
\text { do Programa }\end{array}$ \\
\hline $\begin{array}{l}\text { Eventos } \\
\text { Alternativos } \\
\text { (pessimistas e } \\
\text { otimistas) }\end{array}$ & $\begin{array}{l}\text { Diminuição da } \\
\text { aplicação de } \\
\text { recursos } \\
\text { (por alguns } \\
\text { estados e } \\
\text { municípios) pela } \\
\text { resistência dos } \\
\text { centros urbanos }\end{array}$ & $\begin{array}{l}\text { Indefinição } \\
\text { da condição } \\
\text { profissional } \\
\text { dos ACS }\end{array}$ & $\begin{array}{l}\text { Perfil do } \\
\text { profissional } \\
\text { inadequado } \\
\text { Concurso } \\
\text { público }\end{array}$ & $\begin{array}{l}\text { Aumento da } \\
\text { demanda para } \\
\text { outros níveis } \\
\text { Desintegração } \\
\text { Cesta básica }\end{array}$ & $\begin{array}{l}\text { Estabelecimento } \\
\text { de um sistema de } \\
\text { indicadores de } \\
\text { qualidade, } \\
\text { impacto e de } \\
\text { integração }\end{array}$ & Manutenção \\
\hline
\end{tabular}


É importante assinalar, ainda, que alguns dos atores estudados podem ser arrolados diretamente como variáveis ou dimensões de incerteza: por exemplo, um determinado ator cujo comportamento de futuro é considerado altamente incerto, um ator altamente influente ou o desfecho do conflito entre dois atores estratégicos. Desta maneira, estar-se-ia completando o quadro das variáveis-chave.

O estabelecimento definitivo das variáveis-chave e das hipóteses fundamentais sobre a evolução das variáveis (a partir das estratégias dos atores) não é uma tarefa simples. Como o método de probabilização de Godet supõe o uso de não mais do que seis hipóteses de comportamento, um formidável esforço de redução de variedade se impõe aqui tanto em relação às variáveis-chave quanto às suas hipóteses de comportamento. Restrições de exclusão e de preferência deverão ser aplicadas às configurações possíveis das variáveis; os comportamentos tidos como de possibilidade nula ou baixa deverão ser excluídos; o critério representatividade da variável (de um número maior de outras) deverá ser considerado na escolha das definitivas; combinações de comportamentos (subcenários) deverão ser feitos objetivando a agregação de hipóteses em um número menor; as hipóteses de maior probabilidade média deverão ser assumidas como hipóteses centrais (Benassouli \& Monti, 1995).

Quando o elenco de eventos supera uma quantidade considerada mais operativa, pode-se desenvolver uma consulta a especialistas, na qual estes seriam convocados a opinar sobre a probabilidade estimada para cada evento listado, em termos de nenhuma (0), baixa (B), média (M) e alta probabilidade (A), e ainda sobre a pertinência ou grau de importância de cada evento para o sistema ou problema em análise ( $0, A, M, B)$. Desta maneira, seriam escolhidos os eventos de maior probabilidade relativa e de maior pertinência.

\section{Definição das probabilidades de comportamento individual das hipóteses de comportamento e das probabilidades condicionadas 2 a 2}

Esta fase se caracteriza pela aplicação do método dos impactos cruzados à probabilização das tendências. Neste momento, pode-se atuar de duas maneiras: através da consulta a especialistas e do posterior uso do software (para processamento da informação) ou da obtenção de um consenso argumentativo dentro de um grupo operativo.

A consulta a especialistas: prepara-se um questionário para que os especialistas se pronunciem sobre dois itens: a probabilidade de ocorrência isolada das hipóteses de comportamento ou eventos centrais e as probabilidades condicionadas 2 a 2. Neste último caso, pergunta-se qual é a probabilidade de que ocorra H1 
caso se realize $\mathrm{H} 2$ e qual a probabilidade de $\mathrm{H} 1$ caso não se realize $\mathrm{H} 2$ e assim sucessivamente (H1 em relação a H3, H4, H5 e H6, quando são seis eventos). As perguntas específicas são respondidas de maneira qualitativa segundo um escala de graus de realização das hipóteses, com os seguintes valores: 1 (probabilidade quase nula, muito pequena); 2 (improvável); 3 (probabilidade média); 4 (provável); 5 (alta probabilidade); 6 (eventos independentes). Um histograma com a distribuição das respostas dos especialistas a cada questão formulada poderá ser montado. Em função de uma escala convencional, os graus de realização das hipóteses são transformados em probabilidades quantitativas (de 0 a 1). As probabilidades quantitativas globais por evento vão corresponder às respostas médias dos especialistas.

Por consenso argumentativo: é necessário assinalar que a lógica do método dos impactos cruzados pode ser aplicada sem a necessidade de uma probabilização formalizada ou informatizada dos cenários, apoiada em uma ampla consulta a especialistas. Neste caso, uma matriz de interdependências como a Figura 5 poderá ser útil. Trata-se de uma adaptação da matriz apresentada por Ortigueira (1978). Esta matriz poderá ser construída no interior da oficina de trabalho de prospectiva, baseada no consenso argumentativo alcançado pelos participantes.

Figura 5 - Matriz de impactos cruzados.

\begin{tabular}{|l|l|l|l|}
\hline Eventos & E1 & E2 & E3 \\
\hline E1 & não & $2+$ & $5-$ \\
\hline E2 & $1+$ & Não & $=$ \\
\hline E3 & $2-$ & $=$ & Não \\
\hline
\end{tabular}

Fonte: Adaptado de Ortigueira, 1978.

No caso do uso desta matriz, sugerimos simular os graus de correlação positiva ou negativa eventualmente existentes, podendo-se trabalhar com valores de 0 (igual à independência ou ao sinal =) a mais ou menos 5 , segundo a escala anterior de graus de realização dos eventos (usada no questionário do método SMIC Prob Expert). A título de ilustração, poderíamos dizer que em uma correlação E31, sendo igual a 5- significaria que, se E1 ocorre, a probabilidade de E3 não ocorrer é muito alta. No exemplo anterior, dado o efeito de exclusão de E1 e E3, o cenário relativamente mais provável seria 110. Isto vai depender definitivamente, porém, da probabilidade isolada dos eventos. Sendo assim, sugere-se que na oficina de trabalho os participantes também estabeleçam por consenso as probabilidades isoladas de ocorrência dos eventos, considerando os parâmetros anteriores. 


\section{Identificação das combinações de hipóteses de maior probabilidade de ocorrência e escolha dos cenários definitivamente retidos (Godet, 1998)}

Os resultados dos questionários, traduzidos em probabilidades quantitativas, são transferidos para as matrizes ad-hoc do software. A partir das matrizes quantitativas e contemplando uma série de correções estatísticas, o SMIC ProbExpert permite estimar as probabilidades dos cenários ou combinações de hipóteses possíveis. O método permite estimar a probabilidade de todas as combinações possíveis (no caso de 6 hipóteses, as combinações possíveis seriam 64; no caso de 3 , seriam 8). Cada cenário possível comporta a possibilidade de ocorrência de cada hipótese (1) ou a possibilidade de não ocorrência (0). No caso de 3 eventos, as possibilidades de combinação seriam:

111100110000001011010101 (cada cenário destes teria uma probabilidade)

Quando o elenco de combinações é grande (64 a partir de 6 hipóteses, por exemplo), serão resgatadas as combinações de maior probabilidade (que cubram um campo maior de possibilidades), podendo estas combinações ser reagrupadas em tipos de cenários coerentes ou conexos, considerando as combinações de duas, depois de três hipóteses, que permitam tal reagrupamento.

Além da estimativa de probabilidade dos cenários, o SMIC Prob-Expert permite, nesta fase, fazer a análise de sensibilidade de uma variável (hipótese de comportamento) em relação à outra, através do cálculo dos coeficientes de elasticidade relativos. Esta análise corresponde a saber em que medida varia uma hipótese quando ocorre um delta $\times(10 \%)$ de variação de uma outra (e a saber se essa influência é positiva ou negativa). Isto permite conhecer as hipóteses mais determinantes e as mais dependentes, o qual ajudaria a se ter uma idéia de que hipóteses seria necessário estimular e que hipóteses seria necessário refrear tendo em vista alcançar uma situação desejada.

É importante assinalar que no manejo do SMIC Prob-Expert, o autor se utiliza de mais um artifício, que consiste em analisar as respostas dos vários especialistas e agrupá-los, segundo a homogeneidade das respostas. Desta maneira, pretende-se compensar a dispersão ou a variedade de respostas recebidas (Ortigueira, 1978). Assim sendo, o software permite a estimativa de probabilidades de cenários para cada grupo de especialistas e para o conjunto dos grupos. 


\section{Definição do plano de ação por referência aos cenários centrais}

A sistemática que preconizamos aqui junto com Matus (1994), que concorda em geral com a perspectiva francesa, é aprofundar o desenho do Plano em relação ao cenário central definido pela maior probabilidade de ocorrência, formulando simultaneamente duas alternativas de opção menos detalhadas: uma para a hipótese de um cenário mais otimista; outra para a alternativa de uma cenário mais pessimista. O monitoramento do cenário indicará a necessidade virtual de uma reconstrução do cenário e das opções, da possibilidade de um maior detalhamento das opções marginais referenciadas ao cenário central, ou a afirmação da construção original.

Godet (1993) considera que o plano de ação deveria atender aos seguintes requisitos básicos:

- Trabalhar, se possível, para favorecer a realização dos cenários mais favoráveis aos objetivos de uma organização.

- Limitar as conseqüências nefastas de uma evolução própria do cenário pessimista.

- Facilitar a inserção da atividade futura de uma organização numa envolvente em constante evolução.

\section{Caso: o Programa de Saúde da Família (PSF). Simulação I}

Foi feita uma simulação dos cenários mais prováveis do Programa por parte de uma turma de alunos da Pós-Graduação stricto sensu no contexto da disciplina de Planejamento de Saúde da Ensp (1999). Doze alunos, divididos em quatro grupos, aplicaram as etapas do método de Godet e operaram como especialistas, opinando sobre a probabilidade das tendências apontadas.

Em um primeiro momento, o grupo relacionou as seguintes variáveis de mais alto impacto sobre a evolução do PSF:

- $\quad$ remuneração médica;

- $\quad$ regras de financiamento em nível federal;

- continuidade administrativa do Ministério da Saúde;

- $\quad$ existência de rede de referência e contra-referência eficaz;

- $\quad$ integração do Programa com a rede básica tradicional; 
- controle social;

- formação profissional/ensino universitário;

- $\quad$ fatores de fixação do profissional;

- $\quad$ impacto sobre a saúde da população;

- comprometimento da política municipal de saúde/nível de adesão dos secretários;

- disponibilidade de instâncias técnicas de controle de qualidade;

- ideologia profissional.

Após uma análise da relações de causa-efeito que se estabeleceriam entre as variáveis (análise estrutural implícita, não completamente formalizada), e uma tentativa de agregação das mesmas e de busca das mais representativas, optouse por selecionar as seguintes variáveis de maior motricidade:

- V1: continuidade administrativa da política atual do Ministério da Saúde e das regras subseqüentes de financiamento valorizando o PSF.

- V2: formação universitária e profissional que atualmente estimula a especialização.

- V3: capacidade de integração do PSF com o restante do sistema, com os níveis secundário e terciário.

- V4: capacidade de fixação do profissional, incluindo estímulos materiais e ideológicos.

- V5: controle social e técnico de qualidade.

- V6: nível de comprometimento das secretarias municipais de Saúde, evidenciado pela política municipal de saúde.

A seguir, o grupo fez uma análise estratégica do jogo dos atores na sua interação com as variáveis anteriores. Foram definidos os atores, a governabilidade dos atores sobre as variáveis-chave e a influência dos atores entre si.

\section{Atores sociais e políticos}

- A1: Ministério da Saúde

- A2: Conselho Nacional de Secretários Municipais de Saúde (Conasems)

- A3: MEC

- A4: Conselhos profissionais

- A5: Conselhos municipais de Saúde

- A6: Conselho Nacional dos Secretários de Saúde (Conass)

(Ver figuras 6 e 7 ) 
Figura 6 - Governabilidade dos atores sobre as variáveis-chave.

\begin{tabular}{|c|c|c|c|c|c|c|}
\hline & Financiam. & Form.Univ. & Integração & Fixação & Controle & PMS \\
\hline MS & $\mathbf{A}$ & $\mathrm{B} / \mathrm{M}$ & $\mathrm{B} / \mathrm{M}$ & $\mathrm{B}$ & $\mathrm{B} / \mathrm{M}$ & $\mathbf{M}$ \\
\hline Conasems & $\mathbf{M}$ & $\mathrm{B}$ & $\mathbf{M} / \mathbf{A}$ & $\mathbf{A}$ & $\mathbf{A}$ & $\mathbf{A}$ \\
\hline MEC & 0/B & $\mathbf{A}$ & $0 / \mathrm{B}$ & $\mathrm{B} / \mathrm{M}$ & $0 / \mathrm{B}$ & $0 / \mathrm{B}$ \\
\hline Cons.Prof. & $\mathrm{B} / \mathrm{M}$ & $\mathbf{M}$ & $0 / \mathrm{B}$ & $\mathrm{B} / \mathrm{M}$ & $\mathbf{M}$ & $\mathrm{B}$ \\
\hline C.M.S. & $\mathrm{B} / \mathrm{M}$ & 0/B & $\mathbf{M}$ & $\mathbf{M}$ & $\mathbf{M} / \mathbf{A}$ & $\mathbf{A}$ \\
\hline Conass & $\mathrm{M} / \mathrm{B}$ & 0/B & $\mathbf{M} / \mathbf{A}$ & $\mathbf{M}$ & $\mathrm{B} / \mathrm{M}$ & $\mathbf{M}$ \\
\hline
\end{tabular}

Quem controla o quê, grau de controle em termos de baixo (B), médio (M) e alto (A).

Por argumentar que os conselhos municipais de Saúde poderiam estar bem representados pelo Conasems, o grupo passou a considerar a partir desse momento apenas este último.

Figura 7 - Influência de um ator sobre outro (2 a 2).

\begin{tabular}{|l|c|c|c|c|c|c|}
\hline & MS & Conasems & MEC & $\begin{array}{c}\text { Conselhos } \\
\text { profissionais }\end{array}$ & Conass & Motricidade \\
\hline MS & & 2 & 1 & 1 & 2 & 6 \\
\hline Conasems & 2 & & 0 & 0 & 2 & 4 \\
\hline MEC & 0 & 0 & & 1 & 0 & 1 \\
\hline $\begin{array}{l}\text { Conselhos } \\
\text { profissionais }\end{array}$ & 1 & 0 & 1 & & 0 & 2 \\
\hline Conass & 1 & 1 & 0 & 0 & & 2 \\
\hline Dependência & 4 & 4 & 2 & 2 & 5 & \\
\hline
\end{tabular}

A partir desta análise, chegou-se a algumas conclusões referentes aos atores que controlam prioritariamente as variáveis listadas (relacionados pela ordem de importância) e à influência recíproca dos atores:

- A variável 1 (regras de financiamento) dependeria fundamentalmente do Ministério da Saúde (em primeiro lugar) e do Conasems (em segundo). Estes atores se influenciam reciprocamente de maneira intensa e representariam em geral as forças de maior motricidade.

- A variável 2 (formação profissional) dependeria principalmente do MEC e dos conselhos profissionais, embora se registre uma pequena influência do MS sobre o MEC, contribuindo para moldagem do mercado de trabalho profissional. 
- As variáveis 3 (integração), 4 (fixação profissional) e 5 (controle social) dependeriam fundamentalmente dos secretários municipais e estaduais de Saúde.

- A variável 6 (política municipal de saúde e comprometimento do gestor) dependeria, pela ordem de importância do(s):Conasems; Conselhos de Saúde (estes com uma grande influência sobre o Conasems e sobre a Política Municipal de Saúde (PMS); MS; Conass.

De maneira não-formalizada (sem o uso de matriz ad-hoc), o grupo simulou os principais objetivos associados às estratégias dos atores de maior governabilidade sobre as variáveis-chave e refletiu sobre a viabilidade dos mesmos.

Considerando toda a informação produzida, o grupo se fixou nas seguintes hipóteses de comportamento, eventos ou tendências centrais:

- E1: continuidade do privilégio financeiro ao PSF pela previsão de uma continuidade da equipe ou da política atual do MS (e pelo apoio do Conasems) e por ser a proposta defendida programaticamente também pela oposição. A cobertura poderá eventualmente ser expandida de maneira mais significativa.

- E2: poucas mudanças e muito lentas na graduação e aumento mais expressivo do espaço do Programa na Pós-Graduação a título de especialidade (vide pólos de formação regional das equipes, envolvendo universidades e municípios).

- E3: previsão de importantes problemas de integração por estrangulamentos financeiros relativos aos níveis mais complexos, os quais não acompanhariam as demandas crescentes colocadas pelo Programa em expansão.

- E4: previsão de manutenção dos estímulos materiais à fixação do profissional envolvendo uma remuneração diferenciada

- E5: expansão discreta da importância dos Conselhos de Saúde no controle de qualidade do sistema e das instâncias técnico-profissionais criadas em nível local, para tal fim.

- E6: expansão importante do comprometimento dos gestores de saúde devido à importância crescente do nível municipal, ao baixo custo e à resolutividade do programa.

A seguir o grupo, subdividido, procedeu a estimar as probabilidades de ocorrência das variáveis (isoladas e cruzadas), preenchendo questionário ad-hoc e, utilizando o software, calculou as probabilidades dos cenários e as taxas de sensibilidade. Alguns resultados levantados a partir do roteiro anterior serão expostos aqui. Sobre os eventos de maior motricidade e dependência, teríamos (figuras 8 e 9 , respectivamente): 
Figura 8 - Coeficiente de motricidade dos eventos de maior motricidade do sistema.

\begin{tabular}{|c|c|c|c|}
\hline Grupo & $\begin{array}{c}\text { Coeficiente (valor } \\
\text { global motricidade) }\end{array}$ & Evento & Descritor evento \\
\hline 1 & 2.122 & 5 & Controle social \\
\hline 2 & 1.595 & 1 & Financiamento MS \\
\hline 3 & 1.179 & 6 & Compromisso do gestor \\
\hline 4 & 0.774 & 5 & Controle social \\
\hline
\end{tabular}

Figura 9 - Coeficiente de dependência dos eventos mais dependentes do sistema.

\begin{tabular}{|c|c|c|c|}
\hline Grupo & Coeficiente & Evento & Descritor evento \\
\hline 1 & 1.248 & 2 & Formação profissional \\
\hline 2 & 1.206 & 3 & $\begin{array}{c}\text { Estrangulamento financeiro níveis } \\
\text { complexos }\end{array}$ \\
\hline 3 & 1.012 & 3 & Idem \\
\hline 4 & 0.215 & 3 & Idem \\
\hline
\end{tabular}

O Evento 5 tenderia a ser mais motriz e o E3 seria o mais dependente. Destacam-se também pela motricidade os eventos 1 e 6 .

As maiores taxas de elasticidade específicas seriam as seguintes por grupo (Figura 10):

Figura 10 - Maiores taxas de elasticidade observadas.

\begin{tabular}{|c|c|c|c|c|}
\hline Grupo & 1 & 2 & 3 & 4 \\
\hline Maior taxa & E $25=7,9$ & $\mathrm{E} 41=6,2$ & $\mathrm{E} 46=6,0$ & $E 31=-2,2$ \\
\hline Descrição & $\begin{array}{l}\text { Variação de } 10 \% \text { no } \\
\text { controle social altera } \\
\text { positivamente a } \\
\text { formação profissional } \\
\text { em } 7,9 \%\end{array}$ & $\begin{array}{l}\text { Variação de } \\
10 \% \text { no } \\
\text { financiamento } \\
\text { do MS altera em } \\
6,2 \text { a fixação } \\
\text { profissional }\end{array}$ & $\begin{array}{l}\text { O compromisso } \\
\text { do gestor } \\
\text { variando } 10 \% \\
\text { altera } 6,0 \% \text { a } \\
\text { fixação } \\
\text { profissional }\end{array}$ & $\begin{array}{l}\text { O aumento em } \\
10 \% \text { de E1 inibe } \\
\text { em } 2,2 \% \text { o } \\
\text { evento - } \\
\text { problemas de } \\
\text { integração }\end{array}$ \\
\hline
\end{tabular}

Para apresentar os resultados pertinentes às questões 2 em diante, é necessário expor aqui a probabilidade dos cinco cenários mais prováveis por grupo e para o conjunto (responsáveis por 60,7\% das probabilidades) (Figura 11). 
Figura 11 - Cenários de maior probabilidade segundo os grupos de trabalho.

\begin{tabular}{|c|c|c|c|c|c|c|}
\hline $\mathrm{N}^{\mathrm{o}}$ cenário & Índice & Grupo 1 & G.2 & G.3 & G.4 & Média geral \\
\hline 1 & 111111 & 0.367 & 0.417 & 0.000 & 0.336 & 0.280 \\
\hline 5 & 110111 & 0.000 & 0.181 & 0.221 & 0.168 & 0.143 \\
\hline 3 & 101111 & 0.189 & 0.032 & 0.000 & 0.037 & 0.064 \\
\hline 64 & 000000 & 0.071 & 0.151 & 0.021 & 0.000 & 0.061 \\
\hline 17 & 111101 & 0.000 & 0.000 & 0.089 & 0.146 & 0.059 \\
\hline
\end{tabular}

Analisando as diferenças observadas entre os grupos, podemos concluir que três eventos materializam desacordos em relação à sua ocorrência ou não. São, pela ordem de importância: a capacidade de integração, comprometida pelo déficit financeiro dos níveis mais complexos (o grupo 3 questiona esse evento); o grau de mudança na formação profissional (o grupo 1 atribui 10\% de probabilidade ao cenário 3 , que não prevê mudanças formativas) e o próprio controle social (o grupo 4 atribui 14\% de probabilidade a um cenário (17) onde não acontece o evento 5 de controle social.)

O cenário central ou mais provável é o 1: há uma manutenção dos níveis atuais de financiamento do PSF e uma eventual expansão da cobertura do programa; prevê-se problemas de integração por um déficit financeiro relativo dos níveis mais complexos. Este déficit significaria uma incapacidade de atender a toda a demanda suplementar decorrente dos esforços ampliados de captação do PSF, redundando em problemas de qualidade do atendimento; mudanças muito pequenas são esperadas na graduação profissional, embora se possa prever um esforço importante de montagem de cursos de especialização em PSF; espera-se um comprometimento cada vez maior do município e uma discreta expansão do controle social e técnico da qualidade do programa.

O cenário ideal é o 5 , em que não existiriam problemas de integração do PSF com o restante do sistema. O grupo 3, que defende este cenário, acredita que é possível superar a tendência negativa, mediante uma boa administração dos recursos financeiros, um controle estrito da demanda encaminhada pelo programa e uma melhoria da resolutividade do mesmo (todas estas medidas fariam parte do plano de ação), variáveis que dependem em parte de um bom controle técnico-social da qualidade.

A possibilidade de transitar dos outros quatro cenários mais prováveis relacionados para o ideal (o 110111) define parâmetros para a formulação de uma estratégia de atuação. Haveria dois eventos de expansão discreta, abaixo do desejável e que expressariam fenômenos em torno dos quais se verificam desacordos importantes a respeito de sua probabilidade de ocorrência, que seriam o E2 (poucas mudanças na formação) e o E5 (expansão discreta da importância dos 
conselhos). É interessante reparar que o E5 é um dos de maior motricidade. Sobre esses dois eventos de característica entre negativa, neutra ou discretamente positiva, seria imperativo atuar. O evento 3 (integração) configura um problema de alta probabilidade, embora haja desacordo em relação ao mesmo. A superação desse problema constituiria um objeto privilegiado de intervenção, visando ao cenário ideal. A intensificação de variáveis de maior motricidade por referência às tendências críticas mencionadas e a intervenção junto aos atores que mais controlam os eventos motrizes pertinentes configuram parte importante do manejo estratégico exigido pela situação. O plano estratégico deverá consistir da desagregação de ações visando a impactar principalmente E2, E3 e E5. Especificamente em relação a E2, sustenta-se a necessidade de intensificar a pressão dos conselhos profissionais e das secretarias sobre o MEC, as instituições responsáveis pelo currículo médico e pela formação profissional, e sobre os profissionais, de modo a estimular mudanças curriculares no ensino médico, a incentivar cursos de pós-graduação em saúde da família e a fazer com que os profissionais passem a entender que está se criando uma nova especialidade em saúde com campo para todos os profissionais, o qual já estaria sendo confirmado pela evolução de um mercado de trabalho fortemente induzido pelo MS. Dada a motricidade referida pelos grupos para o E5, o controle técnico e social da qualidade do programa deveria ser intensificado com ações, de modo a ter impacto sobre outros fenômenos dependentes.

Neste exercício, solicitamos que os grupos procurassem identificar os principais modelos mentais (crenças, preconceitos, pressuposições arraigadas) que os outros grupos tinham utilizado na construção de suas "narrativas de futuro".

Os principais modelos mentais questionados nesta simulação foram:

- Falta de resolutividade do PSF, expressa pelo aumento da demanda para os níveis complexos (quando deveria ser o contrário).

- Falta de disposição organizacional para o controle de fluxos de demanda e de cobertura.

- Valorização em demasia da dependência de recursos e não da organização de receitas e despesas.

- Alguns grupos não acreditam no MEC, entendem que os profissionais vêem, na especialização, mais uma fonte de renda com piso salarial definido e que a formação profissional não é prioridade do Programa.

- O controle social é mais um desejo ou utopia, é muito fraco ainda e está menos direcionado pela avaliação e mais pelos interesses político-corporativos de poucos.

Nesta simulação, surgiu um dado novo: a possibilidade de explorar as diferenças de opinião no processo de discussão de formas de intervenção. Da mes- 
ma maneira, os modelos mentais implícitos na apreciação de probabilidades de eventos revelam uma importância singular no momento da formulação de estratégias. Temos a impressão de que eles ajudam a depreender ações e a questionar a probabilidade de alguns eventos, ajudando a cristalizar um maior consenso sobre o futuro e sobre o projeto de ação.

Uma pesquisa consistente dos modelos mentais implícitos e seu uso sob a forma de um diálogo crítico pode atender aos requisitos do entendimento da técnica de cenários como "lembrança do futuro", o qual corresponde, na visão de Senge et al. (1995, da corrente da aprendizagem organizacional), ao uso da técnica como possibilidade de trazer à tona e questionar modelos mentais, com a finalidade de costurar um acordo sobre projetos futuros ou de alinhar a visão dos sujeitos organizacionais.

\section{Simulação 2: o PSF revisitado}

Estes resultados são o produto da discussão e reflexão realizado por um grupo da disciplina de Planejamento de Saúde do Mestrado da Ensp de 2000.

A seguir, apresentaremos os passos da análise realizada, discutindo a escolha das variáveis, o emprego das ferramentas e a seleção dos cenários prováveis.

\section{Passo I: seleção de variáveis}

A partir das características do PSF, definiram-se algumas variáveis que proporcionassem os eixos básicos para a análise do cenário. Vale ressaltar que estas variáveis são profundamente interdependentes.

V1: capacidade de fixação do profissional, destacando a remuneração diferenciada. Principal estratégia observada para assegurar o horário integral e a dedicação exclusiva do médico.

V2: regras de financiamento condicionando o comprometimento do gestor: A disseminação de módulos de PSF pelo Brasil tem sido estimulada, em grande parte, pela política ministerial que proporciona o repasse fundo a fundo correspondente à parcela variável do Piso da Atenção Básica, instituída na NOB-96 e alterada pela portaria 1.882 de 18/12/97 (Brasil. Ministério da Saúde, 1996:53):

O incentivo ao Programa de Agentes Comunitários de Saúde e Programa de Saúde da Família consiste no montante de recursos financeiros destinado a incentivar a implantação de equipes de saúde da familia e agentes comunitários de 
saúde, reorientando práticas, com ênfase nas ações de prevenção de doenças e promoção da saúde. $\left(\right.$ Art $\left.5 \int 1^{\circ}\right)$

V3: articulação com os programas de saúde viabilizando o sistema efetivo de referência e contra-referência: a resolutividade do Programa dependerá, em grande medida, do redimensionamento da rede, e de sua capacidade de integração.

V4: controle social e avaliação permanente: $\mathrm{O}$ controle social através dos Conselhos de Saúde deveria ser a ponta de lança das atividades de avaliação, ajustando as políticas às necessidades e interesses das comunidades. Esta variável é, ainda, importante, pois está fortemente associada ao desenvolvimento e à conquista dos direitos e prerrogativas de cidadania, refletindo o desenvolvimento de outros setores, como educação, emprego, desenvolvimento social em geral.

V5: incentivo à formação profissional adequada ao Programa: formação generalista no que diz respeito ao atendimento médico e baseada na saúde coletiva, pelo componente de promoção em saúde que o profissional deveria exercer.

V6: impacto sobre a saúde da população: Este impacto deverá ser medido através dos indicadores epidemiológicos comumente utilizados e outros indicadores capazes de evidenciar câmbios na qualidade de vida.

V7: flexibilidade e adequação à realidade local: Esta variável tem um significado chave na análise. A experiência revela que, na prática, toda estratégia bem urdida tem uma margem de autonomia e independência na maneira como irá evoluir. Isto se deve à existência de fatores imprevisíveis e/ou imponderáveis no cálculo estratégico. Desta forma, ainda que a flexibilidade não esteja dada no projeto original (o programa é concebido como um pacote único para todo o país, sem considerar diferenças regionais e locais), um certo grau de flexibilização local é inevitável.

\section{Passo 2: análise estrutural}

Através da análise estrutural, é possível mensurar o impacto de cada uma das variáveis sobre cada uma das demais. Desta forma, estabelecem-se as que têm características motrizes e as com características dependentes.

$\mathrm{Na}$ matriz de análise estrutural (Figura 12), observa-se que as variáveis V4 (controle social e avaliação permanente) e V7 (flexibilidade e adequação à realidade local) são as de maior força motriz, ou seja, têm capacidade de influenciar os eventos relacionadas às demais variáveis. As de maior dependência são V6 (impacto sobre a saúde da população), V3 (articulação com os programas de saúde viabilizando o sistema efetivo de referência e contra-referência) e V7 (flexibilidade e adequação à realidade local). A variável V7 funciona como variável de ligação, uma vez que é, ao mesmo tempo, motriz e dependente. 
Figura 12 - Matriz de análise estrutural.

\begin{tabular}{|l|r|r|r|r|r|r|r|r|}
\hline & \multicolumn{1}{|l}{ V1 } & \multicolumn{1}{c|}{ V2 } & \multicolumn{1}{l|}{ V3 } & \multicolumn{1}{l|}{ V4 } & \multicolumn{1}{c|}{ 55 } & \multicolumn{1}{l|}{ V6 } & \multicolumn{1}{l|}{ V7 } & \multicolumn{1}{l|}{ OOTAL } \\
\hline V1 & & 0 & 2 & 0 & 3 & 2 & 2 & 9 \\
\hline V2 & 2 & & 2 & 1 & 1 & 2 & 0 & 8 \\
\hline V3 & 0 & 0 & & 1 & 1 & 3 & 3 & 8 \\
\hline V4 & 2 & 2 & 2 & & 1 & 3 & 3 & 13 \\
\hline V5 & 1 & 0 & 2 & 1 & & 3 & 2 & 9 \\
\hline V6 & 1 & 1 & 1 & 1 & 1 & & 1 & 6 \\
\hline V7 & 2 & 0 & 3 & 3 & 0 & 3 & & 11 \\
\hline TOTAL & 8 & 3 & 13 & 9 & 8 & 16 & 12 & \\
\hline
\end{tabular}

Através do cruzamento da motricidade e dependência (Gráfico 1), observamos que o sistema representado por estas variáveis apresenta-se, em geral, como um sistema instável, ou seja, com predomínio de variáveis de ligação (quadrante superior direito do gráfico), em detrimento das variáveis motrizes (quadrante superior esquerdo) e de resultados.

Gráfico 1 - Distribuição das variáveis segundo motricidade e dependência.

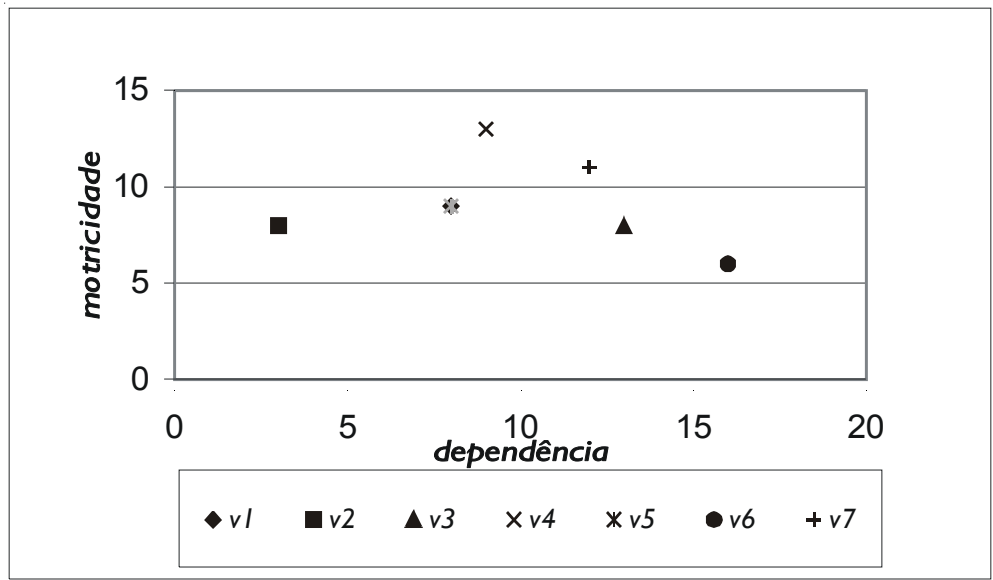

Por considerar V6 (impacto sobre a saúde da população) a variável mais dependente e menos motriz, o grupo optou por excluí-la como variável-chave. V6 corresponde, daqui em diante, à flexibilidade e adequação à realidade local. 


\section{Passo 3: análise de governabilidade dos atores sobre as variáveis}

Tendo em vista as características de instabilidade descritas, recorreu-se a esta análise com o objetivo de aumentar a precisão no momento da definição dos eventos e as tendências centrais do cenário. Vale lembrar que o olhar deste trabalho está dirigido ao nível local do sistema de saúde, ou seja, aquele em que as políticas e programas se traduzem em ações, e não para o nível central, em que políticas e programas são formulados.

Seleção dos atores com interesse e influência no PSF

Ministério da Saúde (MS)

Conselho Municipal de Saúde (CMS)

Gestor Municipal (GM)

Conselhos Profissionais (CP)

Secretarias Estaduais de Saúde (SES)

Agências Financiadoras Internacionais (AFI)

Escolas de Formação de Profissionais de Saúde (EFPS)

Figura 13 - Matriz de influência dos atores sobre as variáveis.

\begin{tabular}{|l|l|l|l|l|l|l|}
\hline & V1 & V2 & V3 & V4 & V5 & V6 \\
\hline MS & A & A & B & 0 & M & B \\
\hline CMS & B & B & M & A & M & A \\
\hline GM & A & A & A & A & A & A \\
\hline CP & M & 0 & 0 & M & A & 0 \\
\hline SES & M & M & A & M & A & M \\
\hline AFI & A & A & 0 & M & A & B \\
\hline EFPS & 0 & 0 & M & B & A & A \\
\hline
\end{tabular}

Observa-se que o Gestor Municipal tem uma importância capital, seguido das agências financiadoras internacionais, do Ministério da Saúde e das secretarias estaduais de Saúde. Lamentavelmente constatamos que os conselhos municipais de Saúde têm influência muito aquém da que seria desejada. 


\section{Passo 4: definição dos eventos de tendência central}

Os eventos constituem hipótese de comportamento das variáveis e são definidos a partir da análise efetuada até este ponto.

V1 - E1: considerando os interesses dos diversos atores a tendência é haver a expansão do programa como política diferenciada.

V2 - E2: há tendência de manutenção de normas de financiamento favoráveis ao PSF.

V3 - E3: há tendência a restringir-se ao atendimento básico (primário) com conflito no que se refere à referência para níveis complexos.

V4 - E4: a consolidação do controle social efetivo e a assimilação de sistemáticas de avaliação acontecem muito lentamente e de maneira pouco efetiva.

V5 - E5: tendência à expansão dos programas de capacitação através de financiamentos próprios para este fim.

V6 - E6: tendência a que surjam aberturas no sentido de uma maior flexibilidade e adaptação às realidades locais.

O grupo avaliou a probabilidade de realização de cada evento isoladamente (Figura 14), bem como a probabilidade de realização cruzando-se dois a dois (Figura 15).

Figura 14 - Probabilidade de ocorrência isolada.

\begin{tabular}{|l|c|c|c|c|c|c|}
\hline Evento & E1 & E2 & E3 & E4 & E5 & E6 \\
\hline Probabilidade isolada & 0.8 & 0.8 & 0.9 & 0.8 & 0.6 & 0.6 \\
\hline
\end{tabular}

A probabilidade de ocorrência isolada de cada evento foi estimada utilizando-se uma escala de 0 a 1.

Figura 15 - Matriz dos impactos cruzados.

\begin{tabular}{|c|c|c|c|c|c|c|}
\hline & E1 & E2 & E3 & E4 & E5 & E6 \\
\hline E1 & & +2 & 0 & 0 & +3 & +2 \\
\hline E2 & +3 & & 0 & 0 & +3 & 0 \\
\hline E3 & -1 & 0 & & 0 & -2 & -2 \\
\hline E4 & -1 & -1 & -2 & & 0 & -2 \\
\hline E5 & +3 & +1 & +1 & 0 & & +2 \\
\hline E 6 & +3 & +1 & -2 & +2 & +2 & \\
\hline
\end{tabular}


O impacto cruzado das variáveis foi estimado utilizando-se uma escala de -3 a +3 . O valor de cada célula representa a probabilidade de que o evento da coluna se realize, no caso de o evento da linha se realizar. O impacto pode representar um estímulo (sinal +) ou uma inibição (sinal -).

\section{Passo 5: definição dos cenários mais prováveis}

O enunciado dos eventos representa, na visão do grupo, a tendência de desenvolvimento das variáveis selecionadas. Portanto, não havendo, na matriz de impactos cruzados, efeito de inibição significativo sobre nenhum evento, e considerando a probabilidade de realização isolada das variáveis, escolheu-se, como cenário central, aquele em que todos os eventos formulados se realizam (cenário 111111). Ainda com base na estimativa de ocorrência isolada dos eventos e na matriz de impactos cruzados, o grupo definiu um cenário pessimista e um cenário otimista em torno do cenário central, contribuindo para uma melhor visualização das ações necessárias para o desenvolvimento do PSF.

\section{Cenário central: $\mid$ | $\mid$ | | |}

Considerando os interesses dos diversos atores, a tendência é haver uma expansão do programa como política diferenciada, bem como a manutenção de normas de financiamento favoráveis ao PSF.

Por outro lado, havendo uma maior abertura na porta de entrada do sistema, é previsível que haja uma pressão de demanda para níveis mais complexos do sistema. Entretanto, as propostas do programa têm se concentrado nas questões pertinentes à atenção básica, não existindo uma preocupação explícita com a resolutividade nem com a garantia de mecanismos de referência e contra-referência. Os atores com maior interesse em concretizar um atendimento mais efetivo - por exemplo, o CMS - têm baixo nível de organização e governabilidade, quando comparado com os demais. A hipótese do grupo é de que o controle social e a assimilação de práticas sistemáticas de avaliação somente venham a se efetivar muito lentamente, o que contribuiria para a manutenção do PSF dentro dos limites da proposta de cesta básica de saúde. Com relação à capacitação profissional, já se observa a introdução de novas linhas de financiamento visando à instalação de cursos de especialização e residência para profissionais de nível superior, além da formação de pólos de capacitação nos estados, visando ao treinamento e à reciclagem de agentes de saúde e outros profissionais. Apesar de toda a dificuldade no que diz respeito ao desenvolvimento de um controle 
social efetivo, observa-se uma importante tendência de flexibilidade e adaptação local determinada pelo próprio fato de a implantação do programa ocorrer no interior da comunidade.

Neste cenário, o plano de ações deveria explorar esta potencialidade de adaptação local, estabelecendo treinamentos e programas de capacitação em que se enfatizem as habilidades de interação e escuta do profissional, tendo como objetivo o aumento da resolutividade do atendimento do PSF. O sistema de referência/contra-referência também deveria ser, aqui, peça central da estratégia de ação, implicando operações de articulação do programa com a atenção básica e com a alta complexidade. Finalmente, o controle social deveria ser objeto de atenção particular devido a sua motricidade e ao seu impacto potencial específico sobre a montagem do sistema e a resolutividade das práticas.

\section{Cenário pessimista: I / I I0}

No cenário central, procuramos definir com bastante realismo as tendências centrais do PSF. Observou-se que o espaço a ser explorado para melhorar o desempenho do programa consiste na possibilidade de flexibilização local devido à própria pressão exercida no nível de implantação dos módulos. Entretanto, a probabilidade estimada de ocorrência isolada deste evento é de apenas 0,6, uma vez que o programa tem importantes traços de centralização e padronização em nível nacional.

Se a flexibilização não se expandir, teremos um PSF sem grandes chances de se tornar um programa resolutivo e impactante, tendendo a tornar-se apenas uma política focalizada.

\section{Cenário otimista: I I00 I I}

$\mathrm{Na}$ descrição do cenário central, observa-se que os dois pontos mais críticos do PSF, na avaliação do grupo, residem na debilidade do controle social como fonte de avaliação permanente do programa, e o baixo nível de articulação da rede de saúde com vistas a um atendimento resolutivo. Desta forma, o cenário otimista é aquele em que estes eventos não ocorrem, ou seja, em que o futuro nos traga a consolidação do controle social e com uma rede hierarquizada de serviços de saúde, capaz de responder adequadamente à necessidade de atendimento. Neste cenário, o PSF não teria dificuldades de produzir os impactos desejados no quadro de saúde da população.

O grupo considera, finalmente, que o PSF enfrentará diferentes cenários e realidades. Por exemplo, nos grandes centros urbanos, onde já existe uma rede 
básica bem estruturada (bem ou mal), um dos nós críticos, em um primeiro momento, será o surgimento de conflitos relativos às diferenças entre o nível salarial dos profissionais do PSF e os dos postos ou centros de saúde, assim como uma possível superposição de papéis, o que provavelmente não será encontrado em regiões mais pobres do país, onde ainda não existe uma estrutura mínima de saúde.

Portanto, o PSF precisa ter pelo menos dois enfoques estratégicos: um para se ajustar à realidade das áreas urbanas onde já existe uma rede estabelecida, de forma a contornar os potenciais conflitos financeiros, de responsabilidades e culturais, e uma outra, para se adaptar à realidade de áreas rurais totalmente desprovidas de cobertura sanitária. Na primeira situação, acredita-se que uma das formas de contornar esses conflitos seria o aproveitamento de profissionais de postos e centros de saúde da rede, para atuar como profissionais do programa, buscando transformar o perfil estático de um posto de saúde, que apenas espera a demanda, em um perfil dinâmico em que se pode provocá-la, através de visitas e ações educativas na comunidade à qual dá cobertura. Já para a segunda situação, acredita-se que os estímulos que favoreçam o deslocamento de profissionais e de recursos devam ser a grande estratégia inicial, para suprir as regiões mais carentes do país.

\section{Simulação 3: análise crítica das construções anteriores}

Em 2002, os grupos de alunos se debruçam sobre os cenários do PSF construídos nos anos anteriores e apontam para novos elementos de análise:

- Há uma maior valorização do papel do MS exercendo influência sobre a formação profissional através da criação de um mercado de trabalho e do incentivo aos polos regionais de formação. Relativiza-se a influência anteriormente aceita do MEC e conselhos profissionais. Há o reconhecimento do seguinte evento: a formação profissional atendendo ao novo modelo está acontecendo de forma gradativa, estimulada pelo novo mercado de trabalho, cursos de pós-graduação, expansão dos pólos de capacitação e o Programa de Incentivo às Mudanças Curriculares das Escolas Médicas (Promed), que visa a apoiar as escolas que queiram adequar seus processos de ensino/produção de conhecimentos e de serviços às necessidades epidemiológicas da maioria da população brasileira, atendendo a excelência técnica e relevância social.

- Um evento crítico que os grupos distinguem refere-se à fixação do profissional. A forma de contratação do profissional que estimule a sua adesão ao 
programa, bem como sua permanência continua sendo um grande entrave, especialmente em regiões mais desenvolvidas. As prefeituras são cautelosas em contratações permanentes, principalmente devido à Lei de Responsabilidade Fiscal.

- Embora o Programa de Expansão da Saúde da Família em grandes centros urbanos (Prodesf) já conte com verba suficiente para os próximos quatro anos, bem como com o incentivo financeiro do Banco Mundial, há muitas dúvidas em relação ao nível de apoio financeiro que estados e municípios possam dar em termos de recursos próprios, devido à resistência que o Programa ocasiona na medida em que se superpõe a uma rede de atenção básica mais densa.

- Os grupos reconhecem o evento positivo de que a grande demanda entrando nos serviços provocará pressões em cadeia para organização dos outros níveis, favorecendo criação de um sistema de referência/contra-referência. Isto seria facilitado pela estratégia da NOAS (2002).

- Um grupo acrescentou, às tradicionais variáveis de financiamento, formação profissional, fixação profissional, flexibilidade e integração sistêmicas e controle social, a variável gestão do programa, não considerada anteriormente.

Os cenários confeccionados obedecem à construção de uma tabela das estratégias dos atores, que inclui a definição de eventos centrais e alternativos, como pôde ser visto na Figura 4. Os três cenários mais prováveis seriam:

\section{Cenário central}

- Aumento do financiamento tendo em vista a eqüidade (aumento do volume do financiamento com recursos próprios dos estados e municípios (EC/29). Aumento do investimento do MS tendo em vista a eqüidade).

- Aumento dos profissionais capacitados para o PSF.

- Dificuldade de fixação do profissional em regiões desenvolvidas.

- Implementação dos papéis definidos pela Noas e interface do PSF com outros programas.

- Aumento da participação dos CMS na implementação do programa. 


\section{Cenário otimista}

- O MS criará indicadores de informação de qualidade de gestão para maior monitoramento dos municípios e disponibilizará formas de divulgação das informações.

- O monitoramento será articulado junto a SES que, devido à implementação da Noas, assumirá com mais ênfase seu papel de gestora.

- O MS se abrirá a para discutir a NOB/98 de Recursos Humanos, em que se discute o Plano de Cargos e Carreiras (PCC).

- A criação do concurso público possibilitará a inserção na carreira pública do PSF havendo maior estabilização do profissional.

\section{Cenário pessimista}

- O financiamento será mantido.

- Poderá ocorrer resistência à expansão do PSF nos centros urbanos e com isso diminuir a aplicação de recursos por estes centros.

- A indefinição da condição profissional do agente comunitário de saúde (auxiliar de enfermagem ou promotor da saúde?) pode prejudicar a relação do mesmo com o programa e com a comunidade.

- O MS e as SMS não investem em estratégias de fixação do profissional, o que provoca maior rotatividade e menor procura.

- O tratamento diferenciado do PSF proporcionará sua manutenção como sistema paralelo de saúde.

Observa-se, no caso da simulação de 2002, um deslocamento dos cenários em relação à simulação anterior. $O$ pessimista deste ano corresponderia ao cenário central da simulação anterior. O cenário otimista seria um cenário marcado pela tentativa de fixar profissionais por meio de concursos públicos e pela busca de uma maior responsabilização através de um monitoramento de qualidade. Poderíamos batizar o cenário de "busca da qualidade". O cenário central se notabilizaria pelos esforços no plano da integração regional e apresentaria, como único evento eventualmente negativo, a dificuldade de fixação profissional em regiões desenvolvidas. Podemos batizar este cenário de "expansão com integração". O pessimista é um cenário com dificuldades de integração, de manutenção. É o cenário de um "programa ainda paralelo".

A partir dessa análise prospectiva, surgem grandes temas de planejamento: o desenvolvimento de um sistema de indicadores de qualidade da gestão e de impacto, incluindo indicadores de integração; disponibilização e padronização 
de formas de divulgação de informações; maior flexibilização do PSF e avanços na integração através da implementação da Noas; novos planos de carreiras e concursos públicos; delimitação clara da condição profissional dos agentes comunitários de saúde; incentivo à participação comunitária através do suporte da mídia e da divulgação de informação etc. A questão da resolutividade do programa é ainda um permanente tema a ser explorado. Terminamos esta parte, trazendo à tona uma polêmica acerca desse tema, que chama a atenção para a necessidade de o Programa de Saúde da Família não perder uma característica basilar de um Programa de Médico de Família, a existência de um suporte importante de supervisão médica especializada ao médico de família, capaz de potencializar a capacidade de resolução da estratégia em geral.

\section{Considerações Finais}

O objetivo deste trabalho, que simplifica didaticamente o enfoque da prospectiva de Godet, é colocar ao alcance do público acadêmico e dos gerentes uma ferramenta poderosa de auxilio à tomada de decisão. No desenvolvimento, vimonos na obrigação de confrontar vários autores "godetianos" e outros latinoamericanos, buscando estabelecer uma lógica de síntese. A leitura que fizemos da escola de Godet é situacional. Implica um esforço de adaptação nosso, à luz de nossa cultura.

É importante que não se tenha a idéia de que este enfoque de prospectiva é de natureza puramente matemática. Como já assinalamos, e é bom salientar de novo, a probabilização matemática dos cenários, da que apresentamos um exemplo, é apenas uma parte infinitesimal de um enfoque mais amplo, em que o julgamento estratégico, a reflexão de natureza qualitativa, literária, de natureza histórica e cultural, ocupam um espaço muito maior. O componente matemático pode, isso sim, ajudar, como um meio e não um fim em si mesmo.

Como ilustramos através de alguns casos trabalhados com os alunos de diferentes linhas de pós-graduação, o nível de formalização pode ser dosificado. Em alguns casos, não se trabalha tanto com especialistas de fora e dentro da lógica de utilizar um programa de computação. A análise é mais interna e qualitativa, respeitando, isso sim, a idéia geral do protocolo. Um dos itens menos explorados, que poderia substituir a consulta ampla a especialistas, diz respeito à necessidade de procurar os atores que controlam variáveis e consultá-los a respeito de estratégias em face das mesmas. Estas entrevistas são ineludíveis e requerem algum tempo, que nós não tivemos. Deste modo, tivemos de trabalhar com simulação, o que não é desejável. A construção do mapa das estratégias do 
atores constitui um dos maiores desafios da prospectiva, pois dele depende a boa formulação dos eventos.

É importante relembrar, aqui, que o rigor da prospectiva pode ser relativizado quando esta técnica é assumida como um conjunto da narrativas mais abertas dos atores, cujo objetivo é trazer à tona as crenças ou preconceitos que sustentam essa leitura do futuro. A discussão sobre esses fundamentos cognitivos e emocionais do olhar para o futuro pode ser crucial para alinhar posições práticas em relação ao mesmo. A prospectiva como lembrança do futuro implica evidenciar a tradição defendida pelos indivíduos para dela se distanciar através do diálogo crítico.

A importância da prospectiva pode ser avaliada em várias dimensões. A principal se refere à tentativa de quebrar a rigidez de posições, aprendendo-se a trabalhar com possibilidades. É a lógica do raciocínio condicional: se acontece tal cenário, atuo assim. Se muda, atuo de outra forma. Aprender a aprender a mudar é o objetivo. Da mesma maneira, como dito anteriormente, o mérito da prospectiva é aprender do futuro, significando a criação de um ambiente que propicia um distanciamento crítico dos determinantes rígidos da cultura.

Para terminar, diríamos que a construção de cenários é um processo que deve ser o mais coletivo possível, para que se reduza a subjetividade inexorável da arte de lidar com o que não está estruturado. Não deixa de ser um diálogo, que às vezes assume caminhos indiretos como o da consulta a especialistas, cujo objetivo maior é antever a ação mais acertada - fruto do consenso possível entre atores que refletem sobre algo complexo como o futuro. A dificuldade inerente ao processo não pode excluir a reflexão, em nome da espontaneidade.

\section{Referências Bibliográficas}

ARAÚJO, J. L. de. Cenários e Modelos para a Análise de Alternativas Energéticas. In: Seminário sobre Matrizes e Balanços Energéticos Estaduais. Planejamento Energético Estadual. CENERGS. Porto Alegre, 1984.

BENASSOULI, P. \& MONTI, R. La planification par scénarios - le cas AXA France 2005. Revue Futuribles, 1 (1), nov. 1995.

BRASIL. MINISTÉRIO DA SAÚDE. Norma Operacional Básica - SUS 1996. Gestão plena com responsabilidade pela saúde do cidadão. Brasília: Diário Oficial da União, 22 de abril de 1996.

BRASIL. MINISTÉRIO DA SAÚDE. Portaria no 1882. Dispõe sobre o Piso de Atenção Básica. Brasilia: Diário Oficial da União, 18 de dezembro de 1997. 
BRASIL. MINISTÉRIO DA SAÚDE. Regionalização da Assistência à Saúde: aprofundando a descentralização com equidade no acesso. Norma Operacional da Assistência à Saúde NOAS-SUS 01/02 (Portaria MS/GM n³73, de 27/01/ 2002).Brasília -DF.

BOURSE, F. Prospective et Systemique: de l'analyse structurelle aux jeux d'acteurs. AFCET/ UAS. Deuxième École Européene de Systemique. Paris, 1992. (Mimeo.)

BUARQUE, S. C. Planejamento Estratégico e Cenários. CENDEC/Brasília/Caderno de Transparências, 1993. (Mimeo.)

ÉCOLE NATIONALE DE SANTÉ PUBLIQUE (ENSP)/Rennes/França. Introduction à la Methodologie de la Prospective et des Scenarios. Dossier documentaire et pédagogique. Département MATISS., février-mars 1997. (Mimeo.)

GODET, M. Prospective et Planification Stratégique. Paris: CPE, 1985

GODET, M. Manual de Prospectiva Estratégica: da Antecipação à Ação. Lisboa: Publicações Dom Quixote, 1993.

GODET, M. SMIC Prob Expert. Methode de Probabilisation des Scenarios. Manuel d'utilization. Paris: Heurisco, 1998.

GRUPO DE ESTUDO ARTUR D.LITTLE. A ambição move o mundo. In: HSM Mangement Estratégia e Planejamento. Autores e conceitos imprescindiveis. São Paulo: PubliFolha, 2002.

HATEM, F. et al. La Prospective - Pratiques et Méthodes. Paris: Economica, 1993.

JOUVENNEL, H. Sur la démarche prospective - un bref guide méthodologique. Revue Futuribles, 3 (2), p.75-89, Paris, Septembre 1993.

KLAN, H. El año 2000. Rev. del Occidente, Madri, 1969.

ORTIGUEIRA, M. La Corporación Cibernética. Granada: Publicaciones del Sur,1978.

MATUS, C. Política, Planejamento e Governo, 2 vol. Brasília: Ipea,1994. (Série Ipea).

REVUE FUTURIBLES. Volume Prospective et Stratégie, 1 (18), nov. 1989. (toda a coleção).

ROUBELAT, F. Les Methodes de consultation d'Experts. In: HATEM, F. et al. La Prospective-Pratiques et Méthodes. Paris: Economica, 1993.

SENGE, P. et al. La Quinta Disciplina en la Práctica. Estrategias y herramientas para construir la organización abierta al aprendizaje. Barcelona: Granica S.A., 1995.

SCHWARTZ, P. A Arte da Visão de Longo Prazo (planejando o futuro em um mundo de incertezas). São Paulo: Zumble/Best-seller, 2000. 



\section{Cultura e liderança COMUNICATIVA
Francisco Javier Uribe Rivera}

$\boldsymbol{A}$ necessidade de um novo paradigma organizacional obedeceria, segundo Crozier (1989), a alguns elementos básicos:

- $\quad$ em um sistema de produção de evolução acelerada, a capacidade de inovar se transforma na qualidade primeira vis-à-vis a capacidade de racionalização;

- a nova lógica dos serviços está muito mais assentada na qualidade do que na quantidade, e neste particular, a noção de atendimento cada vez mais personalizado do cliente torna-se imperativa;

- o recurso humano adquire uma importância extrema na medida em que os esquemas de racionalização produtivista e de produção em massa são superados em grande parte.

- há uma expansão marcante da importância do investimento imaterial, ou seja, do investimento nas pessoas, no sistema de relações, e na cultura, que se desenvolve paralelamente a uma visão da organização como uma sociedade de aprendizagem.

Esse novo paradigma estaria baseado no princípio da simplicidade das estruturas organizacionais, implicando uma relativização da importância das estruturas e dos procedimentos como fatores integradores; no princípio da autonomia das pessoas e das unidades de modo a facilitar a criatividade e o enfrentamento de problemas; e, no princípio do governo da cultura, segundo o qual a organização deixaria de ser regida predominantemente pelas regras de procedimento e/ ou pelas ordens hierárquicas, devendo buscar um mínimo de restrições indispensáveis à coordenação de esforços na cultura que todo grupo humano com uma comunidade de objetivos segrega.

A gerência participativa, as práticas de delegação e de descentralização, a informalização das estruturas, passam a ser os eixos do novo estilo de gerenci- 
amento. A profissionalização ou o desafio de estruturação da organização a partir do conhecimento passa a ser mais importante do que as estruturas e procedimentos.

No contexto desta moldura proposicional, a escuta ou ausculta organizacional torna-se obrigatória. A necessidade de apoiar o projeto de empresa em uma escuta da cultura impõe novos desafios metodológicos e organizacionais. A escuta dos outros, como base do novo paradigma, articula-se a um projeto de comunicação dentro do qual a emergência de um novo padrão de liderança se torna fundamental. Parece que o ideal da liderança forte, carismática, deixa de ser funcional, em prol de um tipo voltado para a mobilização.

Assumindo, aqui, a gestão da escuta organizacional como regra básica, propomo-nos a: apresentar e analisar alguns elementos da ausculta ou auditoria da cultura, de modo a orientar a construção metodológica de uma grade de análise cultural; discutir em grandes linhas a questão da mudança cultural, especialmente o aspecto da evolução cultural ligada ao enfoque da gestão estratégica hospitalar que trabalhamos no livro; e discernir algumas características da denominada liderança comunicativa à luz de algumas contribuições da sociologia organizacional, da gestão pela qualidade e do modelo da organização que aprende a aprender.

A hipótese básica que orienta esta reflexão é a de que, para além da importância das metodologias racionalistas de gestão (planejamento estratégico e gestão pela qualidade), que não é negada, cresce a relevância da compreensão de fatores como a cultura, a negociação e a liderança, consideradas alicerces de uma nova forma de condução baseada na escuta.

\section{Cultura e Mudança Organizacional}

Autores como Matus (1994) e Crozier \& Friedberg (1977) adotam a metáfora do jogo social para caracterizar as organizações. Segundo esta perspectiva, as organizações são reguladas sistemicamente por regras fáticas e/ou legais, observadas por todos os atores organizacionais. Estes produzem suas jogadas ou desenvolvem suas estratégias particulares, em função de interesses parciais, sem, no entanto, alterar ou sobrepujar a moldura das regras gerais (pelo menos, nos tempos curtos).

Na concepção de Crozier \& Friedberg (1977), dois tipos de racionalidade convivem conflitivamente: a racionalidade sistêmica, definida pelas regras do jogo organizacional, e a racionalidade estratégica dos atores. A primeira comporta uma lógica dedutiva, opera da globalidade para a particularidade, focaliza a 
organização enquanto uma agregação que transcende os atores em particular. A segunda está centrada na idéia da organização como construção social, comporta uma lógica indutiva que implica a busca da totalização a partir do particular. Ambas racionalidades se chocam e se supõem mutuamente. Entre as regras e os atores há uma relação circular de causa.

Matus (1994), aplicando sua teoria da produção social ao campo organizacional, estabelece que as organizações têm regras, acumulações e fluxos de produção social. As regras do sistema determinam, em última instância, o poder dos atores, isto é, suas acumulações de recursos organizacionais e de produção técnica, as quais determinam a variedade possível de produtos ou ações. As regras podem, porém, ser transformadas, nos tempos mais longos, pelos atores, dependendo para tal do grau respectivo de acumulação de recursos de poder. No campo organizacional, três regras inter-relacionadas se destacam: a direcionalidade ou a missão, a governabilidade ou o grau de centralização/descentralização e a responsabilidade ou o nível da prestação de contas.

Estas regras, especialmente as de responsabilidade, determinam, para o autor, a qualidade da gestão (como um tipo de acumulação institucional). Quando predomina uma baixa responsabilidade, o dirigente não é cobrado e não sente necessidade de um planejamento estratégico de seus problemas e compromissos fundamentais. Assim, sua agenda é improvisada, irracional, acumulando todo tipo de problemas, de alto e baixo valor relativo. O dirigente tende a concentrar problemas e decisões, e o tipo de gestão pertinente é o tradicional, em que não há uma preocupação com os produtos e resultados finais da organização em relação à sua ambiência externa. A dinâmica inversa operaria em organizações de alta responsabilidade. A gestão por objetivos finais e o planejamento estratégico surgiriam como resultado da cobrança, do controle social.

Mudar a qualidade das acumulações organizativas implica alterar tendencialmente as regras do jogo organizacional, no tocante, principalmente, à responsabilidade. Este é um dos principais desafios da administração pública latino-americana.

Thévenet (1986), teórico organizacional francês, acredita que o sistema de regras organizacionais está condicionado pela cultura. A cultura determina as regras, e estas determinam os sistemas de gestão e a lógica dos atores. No modelo deste autor, a relação é unívoca. Falta, a ele, registrar o efeito inverso, dos atores sobre as regras. Estas ênfase na cultura como fundamento das regras do jogo organizacional parece ser compartilhada por Matus (1994), quando destaca uma sobredeterminação da responsabilidade sobre o conjunto das regras e assume que a base da responsabilidade é a cultura como um conjunto de estruturas mentais.

A cultura é vista por Thévenet como o conjunto de referências compartilhadas organizacionalmente e produzidas historicamente nos processos de apren- 
dizagem inerentes ao enfrentamento contínuo de problemas. As configurações simbólicas típicas da cultura são fontes de comportamentos e se desenvolvem em processos interativos de intervenção sobre a dupla problemática macro das organizações: a relação com o ambiente e a coesão interna.

Para Schein, autor do célebre livro Organizational Culture and Leadership (apud Fischer \& Fleury, 1996), cultura organizacional é o conjunto de pressupostos básicos que um grupo inventou, descobriu ou desenvolveu ao aprender como lidar com os problemas da adaptação externa e integração interna e que funcionaram bem o suficiente para serem considerados válidos e ensinados a novos integrantes como a forma correta de perceber, pensar e sentir, em relação a esses problemas. A similaridade deste conceito com a definição de Thévenet é manifesta.

Thévenet (1993) visualiza a cultura como as regras fáticas do jogo organizacional. Assim como Matus, o autor salienta a importância da responsabilidade no conjunto das configurações culturais. Tratar-se-ia da consciência do dever e da concepção da pessoa humana que predomina na organização, esta última refletida nos sistemas de remuneração e de avaliação.

Vários elementos compõem a cultura organizacional. A partir de uma leitura crítica de Thévenet e de Matus (mentor do Planejamento Estratégico-Situacional, PES) e de uma moldura teórica habermasiana, Rivera (1996) assinala a possibilidade de uma correlação entre o conceito de mundo da vida de Habermas (1987), os componentes culturais declinados pelo autor francês e as regras do jogo organizacional da teoria das macroorganizações do PES.

Uma primeira área de correlação estaria representada pela interseção entre o conceito de direcionalidade do PES e o conceito de cultura como componente estrutural do mundo da vida organizacional. Fariam parte deste campo simbólico elementos como a percepção do ofício pelos agentes organizacionais, o saber técnico ou o saber do ofício, o tipo de percepção do ambiente externo (como recurso ou ameaça) e o projeto real de empresa, visto como o ser historicamente estruturado da organização (missão). Esta área corresponderia à "cultura técnica" ou à simbologia ligada ao projeto tecnológico da organização.

Uma outra área de correlação está dada pelo conceito de governabilidade do PES e pelo de sociedade como estrutura normativa do mundo da vida organizacional. O campo simbólico pertinente incorporaria as representações sociais ligadas ao tipo de estrutura de poder e de condução da organização, ao grau de centralização/descentralização da mesma, às formas de regulação das interações entre os agentes organizacionais. Inerente a este campo simbólico é o enfrentamento do problema da coesão interna.

A terceira área de correlação que se estabelece é aquela que corresponde ao conceito de personalidade (ou de socialização dos sujeitos) como estrutura do 
mundo da vida organizacional e às regras de responsabilidade de Matus (1994). Neste campo simbólico, predominam atitudes e representações ligadas ao exercício da liderança, à concepção da prestação de contas e à capacidade de socialização dos agentes organizacionais, incluindo os processos educativos. A responsabilidade é enfocada aqui como uma conduta interiorizada pelos indivíduos no sentido de solicitar e prestar contas.

Embora esta correlação possa parecer forçada, é útil para ordenar o pensamento e contribuir para tornar claras as principais categorias da cultura que é necessário levantar em um processo de auditoria visando à mudança organizacional. Deve-se considerar que estas três categorizações constituem estruturas ou processos interdependentes, que se nutrem reciprocamente, o que contribui para uma noção mais integradora do conceito geral de cultura, tal como o adotado aqui.

A adoção do conceito de mundo da vida organizacional por Rivera está alicerçada, em grande parte, em Flores (1989). Este autor formula uma concepção lingüística das organizações que incorpora o conceito de mundo organizacional. Este conceito "de mundo da escuta e da relevância" (Flores, 1989:18) está fundamentado em uma leitura heiddegeriana e corresponde à tradição organizacional, à estrutura simbólica que predetermina o conjunto de compromissos institucionais. O conceito de mundo da vida organizacional defendido por Rivera chama a atenção para o conjunto de configurações simbólicas acordadas historicamente e que se constituem no pano de fundo que regula sistemicamente uma instituição, para além dos mundos da vida dos atores em separado.

Duas idéias centrais estão implícitas nesta visão da cultura organizacional como mundo da vida compartilhado. A primeira é a de que a cultura se constitui a partir do agir comunicativo dos agentes organizacionais, em processos de aprendizagem onde se destaca o componente busca do consenso como fundamento do agir. Já de acordo com a segunda, a cultura não é imutável, suas configurações simbólicas podem ser questionadas em um nível discursivo quando se tornam sem função para os agires teleológico e normativo.

Assim, o tratamento dado ao conceito de mundo organizacional de Flores é dialético, habermasiano, no sentido de que se bem a fala e a ação se constituem a partir do mundo da vida, da tradição cultural, esta tradição também pode ser reciclada a partir de uma postura crítica, discursiva.

\subsection{O Método de Análise Cultural}

A proposta de Thévenet é importante para a gerência por dois motivos. Em primeiro lugar, o autor proporciona um enfoque de análise cultural, de audi- 
toria de cultura. Em segundo lugar, sugere uma concepção de trabalho cultural. Deste modo, Thévenet procura operacionalizar um pouco mais a discussão sobre cultura, ajudando a ultrapassar o campo das generalidades do tipo "é muito difícil trabalhar com cultura" ou "a cultura não é instrumentalizável", muito comuns neste campo discursivo.

Em relação ao primeiro ponto, Thévenet estabelece uma distinção marcante entre análise de cultura e análise de clima social. Esta última corresponde a um levantamento instantâneo, fotográfico, das percepções dos agentes organizacionais em relação aos sistemas de gestão organizacional. O resultado é uma média quantitativa de opiniões. Já a análise de cultura pressupõe um levantamento histórico, longitudinal, das representações sociais compartilhadas que subjazem aos sistemas de gestão e situações de fato. O autor afirma que, ao passo que a análise de clima social se interessa pelo que os indivíduos pensam, a análise de cultura se preocupa com o que fazem e com as referências que subentendem sua ação. A cultura não é transparente, não se evidencia de modo claro. A análise cultural comporta uma metodologia complexa que, diferentemente de pesquisar diretamente a cultura, a qual não é abordável em uma primeira aproximação, tenciona registrar os fatos, informações e eventos orientados a representá-la, isto é, aqueles sobre os quais se supõe que ela deixa uma marca. Todo o problema se reduz a saber onde se situam estas marcas. Ou quais seriam os domínios analisáveis. A análise dinâmica da marcas, sinais e indícios da cultura supõe, por outro lado, a organização destas informações em hipóteses sobre a cultura, hipóteses essas que requerem uma validação permanente (buscando a confirmação concreta das mesmas, pesquisando alternativas às mesmas observando empresas comparáveis ou concorrentes, buscando fatos que possam questionar a sua validade ou obrigar a uma maior precisão). Dir-se-ia que a análise cultural supõe uma metodologia "indiciária" e hipotética, de natureza falibilista no sentido de um permanente processo de questionamento.

Thévenet $(1986,1991,1993)$ delimita os eixos centrais, categorias ou domínios de uma auditoria de cultura:

- Uma análise longitudinal dos fundadores e das lideranças marcantes da organização, que procure captar as especificidades, diferenças e negações (em relação ao contexto, da época) do seu projeto e personalidade: impõe-se aqui o levantamento da formação e das características ideológicas do fundador ou liderança marcante, de suas características de personalidade, de sua origem regional, de seus atos e gestos, do seu nível de envolvimento com a comunidade, os princípios que ele sustenta, e fundamentalmente, a caracterização do grau de ruptura ou de desvio que tal figura comporta em relação ao contexto da época. 
- Uma análise histórica das tecnologias ou dos projetos tecnológicos da empresa, procurando captar descontinuidades e acrescentamentos, envolvendo aqui a crucial questão da percepção do ambiente externo e a identificação dos fatores estruturantes das atividades ou produtos organizacionais (da razão de ser).

- Uma análise da importância relativa das diferentes estruturas produtivas da empresa, feita longitudinalmente, de modo a captar, por exemplo, a relação entre administração-meio e estrutura de produção final, entre produção e vendas, entre pesquisa e produção, etc.: do que se trata, neste caso, é de identificar que funções ou áreas organizacionais são mais valorizadas dentro da divisão de poderes.

- Uma análise dos sistemas de gestão visando a captar os valores essenciais ou operantes subjacentes, o tipo de tomada de decisão, o nível de participação, o nível de responsabilização característicos: entende-se que os sistemas de gestão, especificamente os de gestão de pessoal e de avaliação em geral, subentendem um código de valores sobre o que é um bom ou mau funcionário, um bom ou mau produto ou resultado (podem-se conduzir pesquisas sobre o tema por amostragem).

- Uma análise histórica das estruturas de poder, dos organogramas, das convenções, das formas de comunicação e de socialização (com destaque para estas últimas), dos símbolos de diferenciação de status social, da disposição do espaço, das estórias e lendas organizacionais, etc. visando a captar os sinais e símbolos do poder e dos esquemas de interação social, dos hábitos e ritos sociais.

Uma análise deste tipo não parece distante de um tipo convencional de análise organizacional. O que lhe seria específico é a tentativa de descortinar as representações sociais compartilhadas organizacionalmente, ou seja, as lógicas subjacentes aos acúmulos de fatos, às regularidades, repetições e redundâncias observáveis em cada uma das categorias de informação anteriores, que definem as hipóteses culturais propriamente ditas. A presença recorrente de traços de uma categoria de informação (do fundador, por exemplo) em outras (como a análise histórica das competências e/ou dos valores implícitos nos sistemas de gestão) define a possibilidade de hipóteses tidas como mais sérias. Isto não significa que tal ou qual aspecto contido em uma única categoria de informação não seja representativo da cultura, mas que se prefere reter aquele aspecto que tem uma maior chance de ser uma hipótese séria.

É importante destacar que o que interessa, na análise histórica, não é a sucessão detalhista de eventos, mas a apreensão de lógicas fundamentais, e frisar que esta análise - no caso, por exemplo dos fundadores (e de outras categorias) - 
é um tipo de abordagem simbólica que se preocupa com aquilo que é rememorado, retido pelo corpo social como significativo (diferente de que o fundador seja assim essencialmente).

Em artigo nosso, já mencionado (Rivera, 1996), dimensões mais específicas do levantamento de cultura sugeridas por Thévenet foram apontadas.

- A percepção do oficio, da missão, como tendo um papel social específico ou um valor egocêntrico.

- A percepção dos produtos como positivos e de grande valor ou como negativos e de valor fraco.

- O conhecimento da identidade do oficio.

- A importância concedida à capacitação.

- A relação entre a percepção do entorno, a estrutura de poder e a dinâmica organizacional: um entorno ameaçador cria induções no sentido da hierarquia interna, do defensivismo, da luta pela concorrência, de um tipo de comunicação controlada/um entorno ecológico ou percebido como repleto de oportunidades estimula a busca ativa, criativa, de recursos, acompanhando-se, em geral, de formas mais democráticas e flexíveis, e de uma ênfase na inovação.

- O grau de equilíbrio entre os imperativos econômicos, sociais, éticos e morais: como é a vivência dos benefícios implícitos na missão? Este beneficio é restrito ao lucro econômico ou incorpora alguma dimensão ecológica, como o respeito ambiental? Como é a vivência da ordem interna? Como autoritarismo ou democracia? Como é percebido o equilíbrio entre os grupos? Como relação de força ou contrato social?

A metodologia de análise cultural de Schein (2000) pressupõe, como ponto de partida, a análise dos sinais observáveis da maneira de ser da organização (artefatos). As seguintes perguntas podem ajudar a precisar esses artefatos: quando você entrou para esta organização, que detalhes lhe chamaram a atenção? Que aspectos do ambiente de trabalho tipificam, para você, "as maneiras com que fazemos as coisas aqui"? Que regras? Que procedimentos? Que hábitos? A seguir, o autor propõe estabelecer a lógica subjacente aos artefatos. O que levou as pessoas dessa organização a fazer as coisas dessa forma? Esta pergunta ajudaria a discernir as estratégias, metas e filosofias que operam como as justificativas adotadas para os artefatos. O passo definitivo consistiria em buscar os pressupostos culturais subjacentes: as crenças, percepções, pensamentos e sentimentos tomados como naturais (a suma fonte de valores e ações).

Schein chama a atenção para a existência de valores empossados e valores em uso, que corresponderiam ao segundo nível da análise cultural. Isto geraria uma inconsistência entre os artefatos e os valores empossados. Um dos pontos 
de partida da busca dos pressupostos culturais subjacentes reais consistiria em explorar essa inconsistência eventual. Neste sentido, o discurso oficial passa a ser importante material de análise, não tanto pelo que revela, mas pelo que procura ocultar. Fleury e outros (1997) assumem que, pela sua natureza inconsciente, os pressupostos básicos da cultura não se entregam à observação direta e seus significados esgueiram-se por entre as dobras do discurso manifesto dos atores organizacionais. Para revelar seu verdadeiro significado, é preciso ir além das aparências e das primeiras impressões. É preciso apreender os atos falhos dos discursos, os lapsos de memória e as contradições entre o discurso e a prática. Seriam nestes eventos surpreendentes que os conteúdos básicos emergiriam. O método da abordagem clínica de Schein seria capaz de desvendar os significados de eventos aparentemente misteriosos, irracionais ou mesmo tolos, relacionando-os com os pressupostos básicos da cultura.

À medida que são examinadas minuciosamente as contradições detectadas, algumas perguntas relativas a vários domínios de análise seriam cruciais para a distinção dos pressupostos básicos que constituem a cultura (Fischer \& Fleury, 1996):

- A relação com a natureza: a relação com o ambiente é de dominação, submissão, harmonia?

- A natureza da realidade e da verdade: as regras de lingüística e de comportamento que diferenciam o que é real e o que não é; se a "verdade" da organização é revelada ou descoberta ; se o critério de verdade é a argumentação, a credibilidade científica ou outro tipo.

- A natureza humana: a natureza humana é boa, má ou neutra?

- A natureza da atividade humana: o que é considerado "certo" para o ser humano fazer diante dos pressupostos sobre o ambiente, sobre a realidade, sobre a natureza humana: ser ativo, passivo, se desenvolver?

- A natureza das relações humanas: como são distribuídos o poder e o amor? A vida é cooperativa ou competitiva, individualista ou cooperativa, baseada na autoridade, na tradição ou no carisma?

A compreensão do nível mais profundo da cultura pressupõe pensar nas organizações de um ponto de vista histórico, respondendo à pergunta: por toda a história da empresa, quais foram os valores, crenças e certezas dos fundadores e dos líderes que a tornaram bem-sucedida (Schein, 1999)? Os questionamentos anteriores teriam de ser dirigidos preferencialmente à liderança histórica da organização.

Visando a aprofundar a delimitação do item natureza da atividade (como categoria teórica articuladora de pressupostos básicos ou domínio analítico particular), podemos apontar a taxonomia estabelecida por Kluckhohn e Murry 
(Fleury et al., 1997) sobre a modalidade ou orientação (de valor) da atividade humana. Haveria três orientações básicas de valor:

- a orientação do sujeito pelo ser: a ação é orientada pelo desejo existente no indivíduo;

- a orientação do ser em devir: preocupa-se com o que é "dado" na personalidade do ser humano e também com o que ele pode realizar, resgatando a idéia de desenvolvimento;

- a orientação para o fazer: está focalizada na tarefa, na eficiência e na descoberta, sendo que sua característica mais marcante é a demanda de ação, tendo em vista a realização e de acordo com padrões considerados exteriores ao indivíduo que age.

Pertinente ao aspecto da identidade de uma empresa, o grupo Strategor (1997) pondera acerca da existência de três possibilidades: focalização da empresa na atividade ou tarefa (com as características citadas no parágrafo anterior), no carisma (ou estruturação em torno da liderança) ou em um comportamento (o tipo planejado, por exemplo).

Em relação à perspectiva metodológica a ser utilizada para captar as categorias teóricas anteriores, Schein propõe outras categorias a ser investigadas (Fischer \& Fleury, 1996):

- Analisar o teor e o processo de socialização dos novos membros.

- Analisar as respostas a incidentes críticos da história organizacional. Para cada crise é preciso identificar o que foi feito, decidido, e os principais temas adjuntos aos motivos alegados para tomar essas decisões.

- Analisar as crenças, valores e convicções dos criadores ou portadores de cultura.

- Analisar e explorar, junto a pessoas de dentro da organização, as observações surpreendentes descobertas durante as entrevistas.

É importante o grau de complementaridade entre as perspectivas de Schein e de Thévenet. A relevância de considerar os incidentes ou crises mais notáveis da organização para efeitos de um mergulho no simbolismo que apoiou o enfrentamento dos mesmos e de se analisar as estratégias de socialização ou de ajustamento dos novos funcionários à empresa.(como elementos salientados por Schein que podem enriquecer a perspectiva do autor francês). Em relação ao segundo aspecto, o desenvolvimento realizado por Maanen (1996) sobre o tema da socialização dos sujeitos segundo o tipo de treinamento privilegiado (e a possibilidade de ascensão funcional derivada) é particularmente motivante. Referimo-nos ao trabalho Processando as pessoas - estratégias de socialização organizacional, que consta da coletânea organizada por Fischer \& Fleury (1996). Maanen descreve as principais estratégias de ajustamento usadas pelas empresas 
em termos polares: formais/informais; fixas/variáveis; seqüências/não-seqüências; em série/isoladas; por competição/concurso; por investidura/por despojamento etc. Daremos um pequeno exemplo do conteúdo destas estratégias. Uma estratégia de treinamento formal destaca o papel de novato do objeto do mesmo, estabelece uma diferenciação marcante (entre quem treina e quem é treinado) e serve ao objetivo de inculcar novos papéis sociais. Uma estratégia informal é um tipo de aprendizagem mais solidária no próprio trabalho a serviço do desenvolvimento de destrezas dentro de um novo papel. A primeira é mais reificadora do que a segunda, contribuindo para uma maior similaridade. A similaridade é, por outro lado, uma conseqüência mais provável de uma estratégia de formação seriada (inculcação de padrões para um grupo), fixa (concatenação de passos ou requisitos pré-determinados para atingir uma posição, gerando menor mobilidade), e por despojamento (exposição do novato a uma testagem degradante para aceder a uma nova posição, gerando tendência para a domesticação, vide tipo de treinamento militar). Se o objetivo é obter mais diversidade e criatividade, o conjunto das estratégias polares seria mais funcional.

A partir da informação anterior, pode-se montar a seguinte grade de análise cultural, conforme a Figura 1, na página a seguir.

A metodologia de levantamento proposta pelo autor francês se aproxima bastante do modelo apresentado por Fleury, Shinyashiki \& Stevenato, no trabalho Arqueologia Teórica e Dilemas Metodólogicos dos Estudos sobre Cultura (1997). Este modelo do Triângulo Metodológico para o estudo da cultura postula a necessidade de vários observadores de um mesmo objeto, a aplicação de várias teorias e a implementação de vários métodos ou técnicas, procurando-se identificar sua congruência e consistência, a capacidade de gerar dados comparáveis, a complementaridade, a validade externa dos enfoques.

A “triangulação" é definida como a combinação de métodos para estudar um mesmo fenômeno. A metáfora vem da navegação e da estratégia militar que utiliza múltiplos pontos de referência para localizar a exata posição de um objeto. Esta perspectiva, baseada em Duncan (apud Fleury, Shinyashiki \& Stevenato, 1997), comporta o uso de questionários, de entrevistas qualitativas e da observação participante ou livre das redondezas, bem como considera o olhar nativo e o externo e as dimensões qualitativa e quantitativa. Almeja-se, por meio desta "triangulação", compensar as deficiências de um método pelo uso dos demais.

É pertinente acrescentar ainda a assertiva de Schein (1999) referente à metodologia: a cultura não se levanta através de questionário (ou apenas a partir de), mas supõe o recurso ao grupo, o debate com o grupo, pois a natureza da cultural é grupal.

Em relação à elaboração de hipóteses, Thévenet (1993) postula a necessidade de trabalhar a informação levantada em termos de algumas categorias de 
Figura 1 - Componentes básicos da cultura organizada.

\begin{tabular}{|c|c|}
\hline Categoria & Tipo de Informação Possível \\
\hline $\begin{array}{l}\text { Cultura Técnica } \\
\text { (Projeto } \\
\text { Tecnológico) }\end{array}$ & $\begin{array}{l}\text { - } \quad \text { Relação com o ambiente: dominador, passivo, } \\
\text { harmonia } \\
\text { - Continuidades e descontinuidades das } \\
\text { atividades e tecnologias } \\
\text { - Tipo de relação com a atividade: orientação a } \\
\text { partir da pessoa ou da tarefa } \\
\text { - } \text { Identidade empresarial: focalização na } \\
\text { atividade, na liderança ou no comportamento } \\
\text { - Razão de ser das atividades (fatores } \\
\text { estruturantes): o leit motiv argumentativo que } \\
\text { explica a decisão sobre as mesmas } \\
\text { (especialmente em situações de crise e de } \\
\text { mudança) } \\
\text { - Valorização diferencial das áreas de atividades } \\
\text { - Vivência ou percepção valorativa dos } \\
\text { produtos/benefícios da atividade } \\
\text { - Conhecimento da identidade do ofício }\end{array}$ \\
\hline $\begin{array}{l}\text { Normatividade } \\
\text { ou } \\
\text { Governabilidade }\end{array}$ & $\begin{array}{l}\text { - Tipo de comunicação/formas de coordenação } \\
\text { - Vivência da ordem interna - grau de } \\
\text { autoritarismo ou de participação do sistema de } \\
\text { condução/orientação relacional predominante: } \\
\text { individualismo (o bem-estar pessoal predomina } \\
\text { sobre o do grupo), orientação colateral (o } \\
\text { grupo predomina), hierárquica ou linear } \\
\text { (relação colateral mais ênfase na continuidade } \\
\text { temporal)/ordem baseada na tradição, } \\
\text { autoridade legal ou carisma } \\
\text { - Percepção da relação entre os atores: contrato } \\
\text { social ou relação de força? }\end{array}$ \\
\hline $\begin{array}{l}\text { Socialização } \\
\text { dos Sujeitos }\end{array}$ & $\begin{array}{l}\text { - Importância da capacitação } \\
\text { - } \quad \text { Formas de treinamento e de ascensão } \\
\text { predominantes (de ajustamento social) } \\
\text { Responsabilização: nível de formalidade e grau } \\
\text { de crença na prestação de contas. / Concepções } \\
\text { valorativas predominantes na avaliação: o que é } \\
\text { um bom produto, um bom resultado, um bom } \\
\text { funcionário?/E percepção dos deveres e } \\
\text { direitos das pessoas e da empresa } \\
\text { - Tipo de liderança dos portadores de cultura - } \\
\text { análise da especificidade dos fundadores em } \\
\text { relação ao contexto }\end{array}$ \\
\hline
\end{tabular}


análise, de maior recorrência segundo sua experiência: a atividade, a pessoa, o ambiente, a vivência ou uso do tempo, o futuro, a mudança, o serviço público etc. Ilustra a atividade apresentando três bancos com percepções diferenciadas do sentido da atividade: predomínio da relação com o cliente e a obtenção de lucro no primeiro; visão da atividade como tecnicidade financeira no segundo; e percepção do banco como instrumento de apoio financeiro para uma rede de agentes econômicos, industriais por exemplo, no terceiro. Em relação à visão dos direitos e deveres da pessoa vis-à-vis a empresa e vice-versa, o autor ilustra duas situações: uma, em que há uma ênfase marcante no desenvolvimento e formação da pessoa, na sua promoção material e de suas habilidades, junto com a exigência de um envolvimento total; outra, em que a empresa espera de seus empregados o respeito às regras e à hierarquia, há pouca participação, mas cada um dentro da empresa tem a possibilidade de conservar grandes margens de liberdade. O ambiente, ainda, é ilustrado diferencialmente por meio da apresentação de três empresas com hipóteses de comportamento ou de percepção específicas: o ambiente como terreno a ser conquistado, dentro da visão da empresa como líder; o ambiente como conjunto de ameaças das quais é necessário proteger-se; o ambiente como não existente, como simples prolongamento ou conseqüência da atividade ou produto-base.

Thévenet recomenda que a auditoria de cultura seja participativa. Uma das contribuições mais importantes e imediatas que uma auditoria pode ensejar (e que implica uma mudança) é a possibilidade de que os agentes reforcem sua capacidade de compreensão da organização e seu nível de compartilhamento de visões e representações.

\section{Gestão Cultural e Mudança}

Em relação a questão do trabalho cultural, Thévenet formula a seguinte proposição: muito mais estratégico (no sentido de produtivo) do que afrontar uma dada cultura, do que procurar mudá-la ou enfraquece-la, é utilizá-la como recurso para o projeto de mudança. A idéia de cultura como recurso comporta a necessidade de discernir no interior da cultura aqueles traços positivos que podem ser funcionais para a mudança. A recomendação estratégica é procurar apoiar-se na cultura para mudar. Isto não significa que a cultura seja imutável. A cultura é de difícil manipulação no sentido de uma mudança direta. $\mathrm{O}$ autor assinala que é extremamente difícil diagnosticar um determinado estágio $A$ da cultura, na medida em que ela não se evidência claramente (especialmente quando nos situamos desde dentro da mesma). Através de uma metodologia indiciária e hipotética, apenas captamos sinais. 
Porém, muito mais difícil é estabelecer que com o projeto $x$ poderemos levar a cultura do estágio $A$ para o $B$. A cultura, segundo Thévenet, muda nos tempos longos, sempre muda em função do projeto de empresa, mas esta mudança é indeterminada, no sentido de que tanto pode ir para $B$, quanto para $C$ ou $D$. Dada esta dificuldade de lidar diretamente com cultura visando a modificá-la, o autor frisa a necessidade de procurar captar os aspectos positivos de um traço cultural que podem ajudar a mudança, ou que podem ser mobilizados positivamente no enfrentamento de um dado problema. A questão é mais complexa do que se possa supor, pois um mesmo traço cultural pode conter aspectos positivos e negativos desde a perspectiva da abordagem de uma situação problemática. Neste caso, o mais estratégico é fortalecer os aspectos positivos, de modo que potencializem a perspectiva de mudança, enfraquecendo simultaneamente os aspectos negativos. É conhecido o exemplo da autonomia médica como traço cultural, que contém uma positividade do ponto de vista da melhor adaptação de seus produtos e de uma maior dinamicidade, e uma negatividade do ponto de vista da difícil avaliação do trabalho médico. Um projeto que vise a mais eficiência, competitividade teria de apoiar-se no princípio da autonomia dos processos de produção e da centralidade médica, suscitando a participação privilegiada do recurso médico como requisito, e negociar a responsabilização, de modo a debilitar paulatinamente a característica do difícil controle do trabalho médico.

A questão que está colocada aqui é mais de ênfase: a idéia de cultura como recurso chama a atenção muito mais para o discernimento dos valores-chave relacionados com um dado problema que é importante fortalecer para favorecer um ingerência positiva sobre o mesmo. A auditoria de cultura ajudaria a esta tarefa de discernimento. Desta maneira, a questão da cultura passa a ser parte do mundo operacional do enfrentamento de problemas. A relação cultura-problemas passa a um primeiro plano. A cultura deixa de ser vista apenas como obstáculo, para ser focalizada como recurso. Uma recomendação singela do modelo de análise de Thévenet que deve ser destacada, por ser de extremo valor, é a estratégia de procurar agir sempre sobre o que é mais fácil.

Duas possibilidades iniciais se abrem à abordagem cultural como recurso: a adaptação dos projetos organizacionais, a sua modulação ou regulagem, em função da cultura (neste caso, a cultura opera como fator de condicionamento da viabilidade operacional dos projetos, como fator limitante); e o emprego de valores-chave da cultura que podem potencializar um projeto de mudança, o que implica comunicar sobre cultura, trazer a tona e explorar propositivamente a mensagem profunda dos bons valores culturais da tradição complexa de uma organização.

Deve-se retomar a questão da mudança da cultura por ser uma questão extremamente importante. A difícil ingerência sobre a cultura não pode signifi- 
car o abandono da reflexão sobre estratégias de mudança cultural. No nosso ponto de vista, que coincide em boa medida com o de Thévenet, uma atuação direta sobre cultura é possível, mas limitada. Pode dar frutos a longo prazo através da teoria e do treinamento. Este fator, largamente defendido por Matus como capaz de mudar estruturas mentais, é, sem dúvida, de singular importância. Porém, a mudança cultural pode surgir como resultado de uma abordagem indireta, correspondente à implantação progressiva e negociada de um projeto gerencial que se apóie na democratização das estruturas de poder, no fortalecimento da comunicação interna, e no desenvolvimento de formas de avaliação e de prestação de contas. Isto quer dizer que a montagem de sistemas gerenciais enquanto acumulações pode retroagir sobre as regras do jogo organizacional e suas bases culturais, contribuindo para mudá-las, em que pese a imprecisão dos prazos. O alcance de novos resultados positivos no enfrentamento de problemas, derivados de uma melhoria da gestão, pode cristalizar novas representações culturais a respeito das regras organizacionais.

Dada a impossibilidade de uma formula de mudança cultural, propõe-se algo coerente com o princípio habermasiano da correlação entre mundo de vida e agir comunicativo. A abertura de canais de comunicação ampliada, propiciados por reformulações gerenciais, cria as condições e a oportunidade para o questionamento cultural e sua reciclagem, se necessário. As formas de tomada de controle devem acertadas coletivamente sob o pressuposto de que o que se visa é a maior transparência e a participação. Mais comunicação é a estratégia genérica de mudança cultural, pois a comunicação e a cultura se interpenetram de maneira imanente, uma depende da outra.

Afirmamos anteriormente que de qualquer maneira a cultura muda em função do projeto de empresa. Isto quer dizer, entre outras coisas, que haveria uma determinada relação dialética entre cultura e tecnologias, segundo a qual a evolução de tecnologias poderia fazer caducar determinados valores culturais e novos valores culturais podem ajudar a desatar tecnologias emergentes (Habermas,1997). Este é mais argumento a favor de uma visão mais pragmática da cultura, que apresenta uma evolução inexorável, embora indeterminada, induzida pela própria razão técnica. Esta evolução nunca é radical, no sentido de o novo substituir o velho. A cultura apresenta incoerências, traços às vezes contraditórios ou diferentes convivendo em uma tensão dialética, alguns perdendo consistência, outros em cerne anunciando sua expansão. Apoiar a mudança cultural supõe um rodeio estratégico caracterizado pela tentativa de reforçar o novo que surge a partir do velho. É diferente da negação pura simples. É procurar acompanhar a mudança cultural desde dentro da cultura. Se elementos do ambiente externo e a tecno- 
logia contribuem para induzir evoluções culturais, essas evoluções respeitam, inspirados em Maturana (1998), o determinismo da própria cultura, a sua condição de saber de fundo legitimado pela comunicação.

Aspecto fundamental na criação de bases para a mudança cultural é o tipo de liderança. Pensar uma liderança comunicativa implica ver a liderança não mais ligada à supervisão, mais a viabilização dos processos interacionais necessários ao desenvolvimento da organização. Esta liderança, definida em grandes linhas por Crozier \& Sérieyx (1994) e Covey (1994), deveria ser uma liderança preocupada com a motivação dos agentes, com capacidade de negociação na linha do "ganhar-ganhar", uma liderança capaz de incentivar a participação, capaz de promover intercâmbios entre os agentes, uma liderança com visão estratégica dos grandes objetivos, pró-ativa, com qualidades humanas destacadas no campo da socialização e da comunicação etc. A capacidade de mobilização e de integração social são peças-chave de uma proposta de liderança construtiva. A preocupação com a liderança conforma uma área fortemente ligada à constituição da cultura, como defendem Thévenet e Shein.

Pettigrew (1996), no trabalho A cultura das organizações é administrável?, confirma a importância da liderança na mudança cultural e sustenta que a mudança é difícil, porém possível. Entre os fatores que facilitariam essa mudança, o autor destaca: a mudança de crenças na alta administração; um contexto externo receptivo à mudança, favorável; a criação de espaços favoráveis à transformação de uma situação de divisionismo na alta administração em uma condição de maior coesa; a implementação de mudanças estruturais mais ou menos drásticas logo a seguir das mudanças nas crenças, para reforçá-las, e utilização de sistemas de premiação da organização para fortalecer a tendência geral; aproveitamento inteligente das situações de crise importante; uso intensivo da comunicação, através da exploração de modelos de desempenho e busca de um aprofundamento das mensagens valorativas de mudança, priorizando o treinamento e desenvolvimento de pessoal.

Concluiremos este debate sobre mudança cultural com Schein (1999). À luz dos trabalhos de Kurt Lewin, Schein explora um mecanismo de natureza psicológica inerente à mudança, que supõe esta como aprendizado. Para o autor, a mudança é transformadora porque é preciso desprender alguma coisa antes de aprender algo de novo. A motivação para desaprender e aprender algo novo vem da percepção de que, se tudo continuar como está, os objetivos não serão alcançados .Isso gera ansiedade pela sobrevivência (pela culpa). Mas, a percepção do que pode estar envolvido no processo de aprendizado causa a "ansiedade do aprendizado", pois as pessoas podem se tornar temporariamente incompetentes e perder seu lugar no grupo ao fazer as coisas de outra maneira. Para que ocorra a mudança, a ansiedade pela sobrevivência deve ser maior que a pelo 
aprendizado. Isso é conseguido através da redução desta última, proporcionada pela segurança psicológica a ser estabelecida para o aprendiz.

A abordagem da mudança cultural traz à tona a questão da indeterminação. Se a cultura muda, não se sabe ao certo para onde. Esta idéia é um questionamento importante do raciocínio do planejamento estratégico e da qualidade total. Acrescentar a indeterminação da abordagem cultural aos enfoques racionalistas pode significar a possibilidade de um grande enriquecimento no campo gerencial, no nível explicativo e no da criação de possibilidades de intervenção prática. Em si, a abordagem da cultura pode ajudar a explicar eventuais fracassos dos métodos que pressupõem uma previsibilidade elevada. Ela pode ajudar também a modular os projetos elaborados com base nos grandes enfoques gerenciais. Ela nos ensina algo de humildade.

\section{Cultura e Poder}

Fleury \& Fischer (1996) colocam a questão de relação entre poder e cultura. Para eles, o poder molda a cultura, sanciona a cultura permitida e pode transformar a cultura em ocultação e dominação, em ideologia. Esta é uma questão que não podemos eludir aqui. Ela questiona a visão da cultura como conjunto compartilhado de representações sociais. Os autores, entretanto, admitem a dupla possibilidade: a da cultura como conjunto legítimo de valores e a da cultura como dominação.

Esta análise feita desde a perspectiva do poder como meio estratégico obriga-nos a uma precisão conceptual relacionada ao significado de compartilhamento. Cultura no sentido do compartilhamento corresponde a um acordo circunstanciado, a um acerto processual, que não pode desconsiderar as restrições objetivas à tematização representadas pelos meios de regulação formal: o dinheiro e o poder.

A cultura como compartilhamento de valores e configurações é, por outro lado, uma possibilidade, não um dado inexorável. Como Thévenet, falamos em cultura forte e fraca. A auditoria de cultura tem, no diagnóstico da "fortaleza" da cultura, mais um desafio instrumental. Uma cultura forte é uma cultura constituída em termos ideais, como um conjunto legítimo de valores, capaz de regular positivamente uma organização, acima de tudo quando falham os mecanismos de regulação burocrática. Mas, uma cultura forte é uma possibilidade, com variações. Uma cultura fraca, ao contrário, é um tipo de cultura com baixa capacidade de legitimação. Corresponderia a uma situação de fragmentação e de enfraquecimento dos sistemas de idéias como fatores de regulação/legitimação. Neste caso, a integração da ação se daria por uma via plenamente estratégica. 
O que é típico à cultura como cultura forte é, porém, o ato do compartilhamento. Se devemos levar em conta o fenômeno do poder, o mais pragmático é debilitar nossas posições e considerar a cultura como uma metáfora organizacional ao lado de outras, que se integram ou não entre si. Considerar a cultura como ideologia, no sentido de uma cultura fraca, não parece o caminho mais correto. O conceito de cultura fraca não é coerente com o entendimento moderno de cultura.

Habermas (1995), em uma entrevista concedida à Folha de S. Paulo, faz uma interessante distinção entre um sistema normativo factual e um sistema normativo válido, entre facticidade e validade. Um sistema normativo, para ele, pode ser legal e legítimo, ou seja, factual, sem ser válido (está se referindo aos dispositivos normativos da ordem nazista). O caráter de validade estaria dado pela participação do maior número de agentes sociais na gênese da ordem normativa. Dispositivos relativos aos judeus não contaram, sem dúvida, com o apoio da população respectiva, o que lhes retira validade.

Nesta linha de pensamento, podemos precisar melhor o conceito de acordo circunstanciado ou possível, inerente ao compartilhar mesmo de referências sociais como base da cultura, como sendo um sistema de legitimação factual, não necessariamente válido, ou a caminho da validade. É possível falar em cultura factual e cultura válida? Algum tipo de cultura é completamente válido? A validade é apenas questão de orientação ideal, só possível em uma situação de fala ideal?

Falamos em cultura como cultura factual, com uma maior ou menor orientação para a validade. Dada a nossa ordem social, não existe uma cultura completamente válida. A cultura é uma forma de compreensão organizacional, ao lado de outras, capaz de explicar ou não situações concretas na dependência da especificidade e, definitivamente, do nível de legitimação do conjunto cultural. Se ela é uma metáfora organizacional possível, a cultura forte é também uma proposição, que se fundamenta no nível de um programa deliberado visando um tipo de organização cuja dinâmica teleológica obedece aos desígnios normativos que se cristalizam no cruzamento entre o mundo da vida dos atores organizacionais.

Falar em cultura, assim, implica considerar os processos de cristalização de configurações simbólicas veiculadas comunicativamente. A lógica da cultura não é a lógica da integração típica dos sistemas de ação racional. A cultura se relaciona, entretanto, com esses sistemas. O tipo de cultura que corresponde à ideologia faz parte do processo que Habermas (1997) denomina de colonização do mundo da vida pelo sistema. Aqui não há a assimilação por parte do mundo da vida dos atores de uma lógica sistêmica. Há uma invasão de lógicas. Ao contrário, pretende-se que os aparelhos de ação racional passem a obedecer aos impe- 
rativos do mundo da vida. Isto supõe uma inversão na ordem de importância dos três meios que regeriam a ordem social: o poder, o dinheiro e a solidariedade, em favor da última.

\section{Evolução Cultural e Gestão Estratégica}

No capítulo 2, apresentamos as premissas gerais,de ordem teórico-conceitual do enfoque da Démarche Stratégique. Elas ajudam a entender o tipo de movimento de evolução cultural que o enfoque pretende concretizar. Crémadez \& Grateau (1992; 1997), fazendo uma leitura das características das organizações profissionais de saúde, nos moldes de Mintzberg (1982), definem as características do padrão tradicional de identidade hospitalar, entre as quais apresentamos resumidamente: incrementalismo na tomada de decisão; atomização profissional (hierarquias profissionais rígidas em disputa); falta de articulação das especialidades; descentralização acentuada do poder, estrutura organizacional achatada; duplo comando: administrativo e assistencial; o tabu da incompetência do outro (fraca valorização da avaliação e da gestão); visão funcional do usuário e pouca abertura para o ambiente externo; redes relacionais espontâneas, baseadas nas identidades criadas nos processos de formação/socialização anteriores; estilo liberal da profissão.

Se os autores reconhecem a presença deste padrão tradicional, não é menos verdadeiro que também distinguem uma crise paradigmática da medicina, do serviço público e da formação profissional, que aponta para o surgimento de características socioculturais contraditórias com aquele padrão. Eles chamam a atenção para novos traços, tais como: uma demanda crescente de gestão decorrente da concentração tecnológica em grandes burocracias hospitalares, que limita a concepção de medicina liberal; um crescimento da importância da racionalidade econômica pela crescente interpenetração do técnico com o tecnológico; a necessidade de um enfoque de rede, de parcerias, de trabalho em equipe, que questiona a fragmentação das especialidades e das instituições; um maior grau de interdependência entre setores e serviços na fundamentação de diagnósticos e condutas terapêuticas; um encontro crescente de especialistas diversos em torno de tecnologias emergentes, de uso comum; novas modalidades de atendimento que agrupam diversas especialidades, favorecendo a comunicação entre si etc. Desta maneira, os autores reconhecem um quadro cultural contraditório, em transição.

Dentro desse contexto, a gestão estratégica operaria como reforço indireto dos aspectos positivos dos traços culturais em evolução, "em cerne", através dos seguintes elementos ensejados: reforço da capacidade explícita de fixação de 
prioridades, dentro de uma perspectiva de totalização da organização que supere o incrementalismo; visão predominante da perspectiva da contribuição e não da atribuição: a visão de custo-oportunidade obriga a comparar os benefícios alternativos de uma aplicação, priorizando-se os usos de maior benefício para organização como um todo, em detrimento da barganha indiscriminada de recursos; sentido de rede, da criação de transversalidades; formalização do planejamento e da avaliação, contribuindo para apreensão clara da organização pelos atores (através de uma linguagem comum); criação de lugares de encontro, de comunicação; maior relacionamento entre gestores e operadores; ênfase na negociação, na avaliação da competência global dos serviços em face dos usuários; fortalecimento do sentido de bem coletivo da atividade.

\section{A Liderança Comunicativa}

Crozier \& Sérieyx reúnem, no livro Du Management Panique à l'Entreprise du XXI Siécle (1994), a síntese dos trabalhos da conferência internacional "Em busca da organização de amanhã”, organizada pelo grupo canadense Inovação. Nesta conferência, que contou com grandes pensadores da área do gerenciamento, faz-se uma constatação crítica dos impasses com que se depara esta área. Os autores participantes defendem profundas mudanças no estilo de gerenciamento e nas formas de organização do trabalho, de modo a que as instituições possam melhor se adaptar aos desafios do futuro. Um tema recorrente no texto é a necessidade de um novo padrão de liderança, cuja emergência representaria uma das condições favoráveis à mudança organizacional almejada.

O conferencista que dá corpo à discussão sobre liderança é Warren Bennis, especialista no assunto.

Conceituando liderança, Bennis afirma que o poder deve ser a energia fundamental necessária para lançar e sustentar uma ação ou, dito de outro modo, a capacidade para traduzir a intenção em realidade e de sustentar a ação. A liderança é o uso judicioso deste poder.

Uma liderança eficaz e bem exercida poderia fazer com que as organizações passassem de um estado presente a um estado futuro, criassem perspectivas potenciais e inspirassem nos trabalhadores vontade de mudar e introduzir novas filosofias e estratégias, de modo a mobilizar e focalizar as energias e os recursos existentes.

As organizações sofreriam de uma saturação de gestão "procedimental" e de uma ausência flagrante de liderança. Em função desta falta, as organizações teriam concentrado suas energias nos instrumentos de gestão, criando, muitas vezes, monstros burocráticos. 
Para Bennis, haveria uma diferença básica entre o gerente e o líder: a liderança sabe o que é necessário fazer, ao passo que o gestor sabe como fazer bem. O autor relaciona vários papéis essenciais para distinguir gestão e liderança. A gestão cuidaria da administração, o líder da inovação; a gestão da manutenção, a liderança do desenvolvimento; a gestão trataria do sistema e da estrutura, a liderança, das pessoas; a gestão se preocuparia com o curto prazo, a liderança, com o longo prazo; a gestão se preocuparia com o como, a liderança, com o que e o porquê; a gestão trabalharia com a obediência, a liderança, com o engajamento; a gestão com o controle, a liderança, com o poder. O líder se preocuparia em canalizar a atenção sobre uma visão, explorando os recursos emocionais e espirituais da organização, seus valores, seus engajamentos e suas aspirações; já o gerente exploraria os recursos físicos da organização, seu capital, suas competências, suas matérias-primas e sua tecnologia (Quadro 1).

Quadro 1 - Distinção entre Gestão e Liderança.

\begin{tabular}{|c|c|}
\hline Gestão (fazer bem as coisas) & Liderança (fazer as coisas certas) \\
\hline - $\quad$ administração & - $\quad$ inovação \\
\hline - $\quad$ manutenção & - desenvolvimento \\
\hline - $\quad$ sistema/estrutura & - gente/confiança \\
\hline - $\quad$ curto prazo & - longo prazo \\
\hline - como? & - $\quad$ o quê? por quê? \\
\hline - obediência & - comprometimento \\
\hline - controle & - $\quad$ poder \\
\hline
\end{tabular}

O líder estaria centrado prioritariamente no lado humano, ao passo que o gerente estaria atento aos processos, sistemas, mecanismos. O segredo estaria, talvez, em um equilibrio entre gestão e liderança, variando esta dosagem de acordo com as circunstâncias.

O verdadeiro líder encorajaria e valorizaria uma prática muito mais direcionada para projetos dinâmicos do que para comitês. Para Bennis (2001), as equipes destes projetos se caracterizariam por privilegiar o cliente, por possuir objetivos precisos e trabalhar em um clima de autonomia, de abertura para o exterior e de responsabilidade. Dentro de uma perspectiva de reforço da equipe ou do grupo, a liderança pareceria ser antes a exploração das competências portadas por uma maioria do que a colocação em evidência das competências de uma minoria. 
A liderança dependeria da aprendizagem e poderia ser vista como um processo profundamente humano, pontuado de ensaios e de erros, de vitórias e derrotas, de cálculos e acasos, de intuição e perspicácia. Aprender a ser um líder depende dos valores fundamentais e dos modelos de papéis fornecidos pela infância e pela adolescência, mas todo o resto se adquire ao cabo dos anos e das experiências pessoais (Bennis \& Nanus apud Crozier \& Sérieyx, 1994).

Neste processo de aprendizagem, o desenvolvimento da liderança se inspira em modelos que "dão o exemplo". Bennis (2001) afirma que, se temos líderes fortes desde o início, eles criarão atitudes e um ambiente no qual a liderança poderá desenvolver-se. Este seria um dos paradoxos curiosos do sucesso e do fracasso: o fracasso leva a mais fracasso e o sucesso, a mais sucesso.

A liderança, no entanto, não se relacionaria à posição hierárquica ou à função exercida. Nas organizações modernas, cada trabalhador deveria ser o líder de alguém, sobretudo de si mesmo. Essa compreensão coincide com o questionamento teórico feito pelo autor a cinco grandes mitos: a liderança é um dom raro; os líderes são natos, não feitos; são carismáticos; só existe liderança no escalão mais alto da organização (o mais importante); o líder controla, dirige, estimula, manipula (Bennis \& Nanus, 1985). Isto é, porém, contraditório com a utilização, pelos autores, de uma semântica recorrente sobre líderes fortes e vigorosos. Por exemplo, com a afirmação taxativa de que todo grande grupo tem um líder vigoroso (Bennis \& Biederman, 1999).

Bennis chegou à conclusão de que a qualidades de um bom líder (ou da "liderança transformadora") correspondem freqüentemente àquilo que os empregados esperam dele. Estes esperariam que seus líderes lhes indicassem uma direção, lhes inspirassem confiança e lhes ofereçam esperança. Para responder à expectativas dos empregados, os líderes teriam de ser resolutos, ter um bom caráter e ser otimistas ou convencidos de sua eficácia pessoal.

Após analisar traços pesquisados de "grandes líderes", Bennis identifica os requisitos de um líder em ordem de prioridade: comunicar sua opinião sobre a sua visão da organização; articular compreensão e desempenho; estar freqüentemente em contato com seus empregados; colocar ênfase na ética; planificar a sucessão administrativa; comunicar-se regularmente com os clientes; despedir empregados cujos rendimentos são insatisfatórios; recompensar a lealdade; tomar todas as decisões importantes ; adotar uma posição conservadora (no plano dos costumes e da observância hierárquica).

Especial ênfase é dada à necessidade de conjugar capacidade visionária e capacidade gerencial e à capacidade de obter, de apresentar resultados (Bennis, 2001). O autor assinala também duas características que se repetem nos líderes 
que se vêem em casos de fracassos: Uma combinação de falta de perspectiva, arrogância e o não saber ouvir, bem como a falta de inteligência emocional ou interpessoal (Bennis, 2001).

A primeira qualidade positiva ressaltada corresponde à determinação para buscar e alcançar seus objetivos, para formular e lutar por uma visão. Crozier \& Sérieyx fazem o seguinte comentário: como os grandes desafios, a visão desperta a capacidade coletiva. Os líderes, sustenta Bennis, geram a mobilização graças a uma potente visão capaz de fazer descobrir aos outros horizontes que lhes eram desconhecidos até então.

Determinar e imprimir uma direção corresponderia também a adotar um ponto de vista, partilhando "seu sonho" com o conjunto da organização para que esta possa aderir por um longo tempo. Para obter essa adesão o líder deveria ser capaz de fazer aceitar sua bem fundamentada argumentação sobre a sua visão.

Bennis (2001) destaca, no tocante à visão, a necessidade de desenvolver uma perspectiva, assinalando que é fundamental colocar-se um passo à frente e ter alguma perspectiva sobre o que está acontecendo, especialmente quando os cenários das empresas tornam-se mais complicados.

Em relação à visão, que depende de desenvolver a perspectiva e a paixão,o autor acrescenta, como fator fundamental do exercício da liderança, a capacidade de atribuir à ação um significado particular. Em outras palavras, é preciso perceber a existência de algum propósito de trabalho, que vai além das pessoas. Esse fato supõe que o ambiente sinta que está realizando um trabalho que faz diferença.

Para Crozier \& Sérieyx, interpretando Bennis, a motivação seria um conceito infantilizante, que não teria efeito algum sobre pessoas altamente escolarizadas; se as pessoas estão mobilizadas, elas se motivariam por si mesmas. Isto corresponde a entender que a motivação não é induzida externamente, mas é resultado da própria pessoa quando é mobilizada a participar dos destinos da organização e a desenvolver suas potencialidades individuais.

Para mobilizar a inteligência dos indivíduos, e não sua simples obediência, seria necessário um elemento novo, não previsto até então pela gestão de recursos humanos e a administração tradicional: que o empregado queira autenticamente, pessoalmente . E para tal, lhe são necessárias razões, válidas de seu ponto de vista. Nem a manipulação, nem a sedução, nem o terror (ameaça de cortes) têm tido êxito neste campo,como se pode ver perfeitamente nos nossos dias (Crozier \& Sérieyx, 1994).

O melhor caminho para a mobilização livremente consentida passaria pela comunicação; em uma época em que o poder da função passa a se desgastar, a comunicação seria um elemento essencial da liderança, e se constituiria num 
elemento integrador de práticas e de novos comportamentos na gestão. Significaria convencer os demais da justiça de sua visão.

Para que a mobilização em torno de uma visão possa ser efetiva, o líder deveria igualmente inspirar confiança, a qual estaria relacionada não só à exemplaridade, mas igualmente à constância e à coerência. A melhor maneira de demonstrar a coerência, além do seu próprio comportamento, seria passar de intenções a atos concretos, modificando, por exemplo, os processos de gestão e a estrutura organizacional (Bennis apud Crozier \& Sérieyx, 1994).

A confiança estaria em um tênue equilíbrio entre três elementos fundamentais: audácia, competência e integridade. A liderança valorizada seria aquela que dissipa surpresas, que está impregnado por uma visão que emana de seus poros e corresponde e estaria relacionada a uma visão otimista e motivante do futuro.

A liderança transformadora de Bennis seria como uma peça em três atos: o primeiro corresponderia a reconhecer a necessidade de revitalização da organização; o segundo seria criar uma nova visão; e o terceiro, institucionalizar a mudança.

Essa visão dá uma interpretação um tanto personalista à liderança, ao colocar na pessoa do líder plenas possibilidades de conduzir o conjunto organizacional para a mudança, em detrimento aparente de uma construção coletiva. Condições resultantes de restrições sistêmicas e de complexas interações entre os sujeitos organizacionais ficam subsumidas à sua interpretação e direção.

Em termos críticos, podemos sustentar que os aspectos comunicativos sobejadamente presentes no modelo de Bennis podem ser empobrecidos pela busca da adesão do coletivo a uma visão pré-determinada pelo líder, o qual daria a esta prerrogativa de formulação e comunicação da visão um caráter um pouco indutor, estratégico. $\mathrm{Na}$ realidade, observamos no autor incoerências naturais: às já assinaladas, acrescentamos uma certa ênfase na necessidade do modelo hierárquico (embora com adaptação, flexível) e afirmações de cunho estratégico como, por exemplo, a de que a criatividade de um grande grupo supõe a presença ou a invenção do inimigo externo (Bennis \& Bicderman, 1999).

Entretanto, em nossa visão, a concepção dos autores tem aspectos extremamente relevantes a se ressaltar. Merecem destaque, na visão de Bennis, a valorização do trabalho em equipe, da capacidade de precisão de objetivos dos coletivos, da busca por parte dos mesmos de autonomia e de abertura para o exterior, requisitos que, a nosso ver, contribuem para a socialização e a responsabilização dos indivíduos. É extremamente pertinente, ainda, a sua visão da liderança como dependente de um processo de aprendizagem que se realiza na experiência histórica e pessoal de cada um, na interação com os outros. A valorização primeira do lado humano ao invés do tecnológico e procedimental contribui 
para uma liderança que não busca manipular, mas agregar os valores e motivações fundamentais de cada indivíduo que integra a organização. Diferentemente da lógica do controle inerente à gestão tecnoburocrática clássica, o fenômeno da liderança atuaria como o exercício do poder para o desenvolvimento de dinâmicas de equipe e de interação disciplinar que favoreceriam a inovação e a mudança. A promoção da liderança dependeria muito de um tipo de aprendizado caracterizado pelo trânsito cultural entre disciplinas diferenciadas e informações aparentemente distantes. Esta linha de pensamento reforça, portanto, a idéia da liderança como processo de aprendizagem e como instância de mobilização das capacidades individuais e intersubjetivas da organização. É importante frisar aqui que o autor acredita que a conquista de vantagens competitivas depende, em grande medida, da criação de um clima amplo de interação de idéias, da capacidade para criar um modelo organizacional e a arquitetura social que permitam gerar capital intelectual, da possibilidade de liberar o poder cerebral de cada pessoa de uma equipe (HSM Management; 2001).

A relevância dada, na gestão, às pessoas, secundariza o aspecto de aparelho. Valoriza os valores presentes nos indivíduos, a autonomia, a responsabilidade e a abertura da organização para o meio. Ressaltam-se os aspectos éticos, de caráter e a capacidade do líder para mobilizar a equipe. Capacidade do líder para a mobilização e integração que destaca o investimento na comunicação, como forma de "argumentação" da sua visão e de seus atos.

São elementos que, a nosso ver, ressaltam aspectos capazes de construir uma ética voltada para a comunicação e para a responsabilização com os objetivos da missão organizacional. Porém, uma liderança que se pretenda voltada para a democratização das decisões e para o entendimento intersubjetivo, mais do que argumentar sobre a sua visão, necessita ensejar a todos os envolvidos nos processos de trabalho da organização, a possibilidade da argumentação discursiva, e a tomada de decisão com base em consensos daquela decorrentes.

A qualidade de ser líder, em uma reconstrução voltada para a dialogicidade, diz respeito, fundamentalmente, à sua capacidade de mobilizar os sujeitos oganizacionais e de promover a argumentação entre os sujeitos sobre as suas visões da missão, dos objetivos para alcançá-la e das ações necessárias correspondentes. Esta seria uma liderança calcada na ética e na capacidade de buscar o alcance da missão pela competência cognitiva e relacional, fundada na promoção da integração dos sujeitos para o alcance de um adequado desempenho organizacional. Esta seria uma liderança voltada para a responsabilização e a socialização dos sujeitos organizacionais.

São elementos que, a nosso ver, ressaltam aspectos capazes de construir uma ética voltada para a comunicação e para a responsabilização com os objetivos da missão organizacional. No entanto, uma liderança que se pretenda volta- 
da para a democratização das decisões e para o entendimento intersubjetivo, mais do que argumentar sobre a sua visão, necessita ensejar a todos os envolvidos nos processos de trabalho da organização, a possibilidade da argumentação discursiva, e a tomada de decisão com base em consensos daquela decorrentes.

O papel da liderança é, para Covey (1994), o substrato básico sobre o qual estaria assentado o movimento pela qualidade total, e o alcance do sucesso em sua implementação estaria baseado, mais do que nos seus procedimentos, na implementação de princípios e práticas essenciais, desenvolvidos no seu livro Liderança Baseada em Princípios (1994). Os fundamentos da liderança estariam baseados na idéia de que buscar qualidade é priorizar uma orientação voltada para as exigências e necessidades do cliente, e de que a qualidade como resultado ou produto é função da qualidade como processo de produção. Esta última meta geral de qualidade dependeria do grau de envolvimento dos atores organizacionais decorrente do exercício da liderança.

O requisito mais importante para a "transformação do modo ocidental de fazer administração" estaria no princípio de que "a tarefa do administrador é liderar e não supervisionar” (Deming apud Covey, 1994).

Se o modo tradicional de realizar administração perceberia as pessoas como produtos ou "coisas", seria tarefa dos líderes voltar-se para a valorização das atitudes e valores básicos daquelas, despertando-lhes as suas motivações intrínsecas e desenvolvendo suas capacidades, como idéias e criatividade, pressupondo uma liderança fundada na delegação de poderes.

A realização de uma mudança cultural profunda, para Covey (1994), partiria da mudança pessoal para a mudança organizacional. Uma liderança proativa, voltada para as pessoas, seus comportamentos e interações partiria do compromisso com princípios que seriam "estáveis e imutáveis", correspondendo ao desenvolvimento de sete hábitos baseados nos 14 princípios de Deming, um dos maiores ideólogos da qualidade.

O primeiro hábito relacionar-se-ia à proatividade, significando a tomada de iniciativa por parte das pessoas como resposta aos estímulos externos, baseada no exercício de seus próprios princípios. Estas estariam menos sujeitas ao controle de forças e condicionamentos externos e assumiriam a sua capacidade e responsabilidade para mudar a si mesmas, o ambiente e influenciar os outros. A proatividade estaria assentada no hábito de tomar decisões e em um agir baseado em princípios e valores.

O hábito que focaliza a relação entre liderança e missão representaria uma preocupação maior relativa com o desenvolvimento de relacionamentos do que com a gerência de equipamentos; com os valores e princípios ao invés das atividades; teria em vista mais a missão, os objetivos organizacionais e a sua direção 
do que os métodos, as técnicas e a velocidade. A declaração da missão pessoal e organizacional seria o seu ponto-chave.

O terceiro hábito diz respeito ao princípio de administrar tempo e prioridades em torno de papéis e objetivos. Compreenderia desenvolver um cronograma de prioridades a partir da avaliação dos objetivos pessoais e organizacionais. O desenvolvimento da capacidade da organização para a "qualidade total" seria maior quando as atividades têm alto significado e prioridade para as pessoas.

Outro hábito, o quarto, baseia-se no princípio do benefício mútuo, que advoga relacionamentos ganhar-ganhar entre todas as partes envolvidas em qualquer empreendimento, até mesmo entre os concorrentes, necessários para o alcance da eficácia a longo prazo.

Já o princípio da comunicação empática seria a base do hábito cinco: buscar compreender sinceramente as outras pessoas seria o seu fundamento. Envolveria o estabelecimento de uma comunicação entre as pessoas, com compartilhamento não só de palavras, idéias e informações, mas de sentimentos, emoções e sensibilidade.

O hábito seis estaria relacionado com o hábito da cooperacão criativa, com os integrantes da organização estando conscientes das relações de interdependência entre as partes, tornando possível gerar criatividade, melhoria e inovação.

Por sua vez, o hábito sete, "afine o instrumento", diria respeito ao princípio da melhoria contínua. As pessoas e as organizações possuiriam quatro grandes necessidades ou características: (1) físicas ou econômicas; (2) intelectuais ou psicológicas; (3) sociais ou emocionais e; (4) espirituais ou holísticas. A capacidade das pessoas para o compromisso com a melhoria envolveria o investimento da liderança no desenvolvimento dessas quatro áreas, e resultaria na "organização do aprendizado, base da melhoria contínua de sistemas, processos e resultados".

Esses princípios de Deming sistematizados por Covey são consoantes com uma perspectiva não personalista da liderança. Seus fundamentos se coadunariam, a princípio com a noção de partilha de valores, entendimento entre as pessoas e aprendizagem coletiva, e com a noção de que a coordenação da ação deve envolver ganhos para todos os envolvidos.

Limerick, Passfield \& Cunnugton (1994), interpretando o paradigma da organização aprendiz, resume com extrema pertinência os traços de uma liderança comunicativa, quando se refere a um dos mentores ideológicos do movimento, Peter Senge: em uma organização que aprende, o papel da liderança difere dramaticamente da visão do decisor carismático; ela é responsável por construir organizações onde as pessoas estão continuamente expandindo suas capacidades para moldar o futuro - isto é, a liderança é responsável pela aprendizagem. 
Sustentando a defesa da mudança incremental (progressiva e baseada na aprendizagem coletiva) por oposição à corrente da mudança transformacional (modificações mais abruptas tendo como base lideranças fortes), o autor questiona algumas crenças referentes ao líder transformacional, tais como: líderes fortes são necessários para a mudança (não apenas bons executivos, mas líderes fortes); a impossibilidade de delegar funções estratégicas a gerentes subordinados, como a definição da missão principal, a definição dos valores da corporação, a especificação da demanda do ambiente desejável e das respostas do sistema etc.; a visão do líder como um indivíduo solitário, capaz de mobilizar emoções, absorvido por ideais, carismático.

A concepção de uma organização em permanente processo de aprendizagem da experiência, de ensaio e erro, de geração da informação e das capacidades necessárias a um questionamento sistemático de sua performance e a uma evolução continua de suas habilidades, não se coaduna, segundo o autor, com um visão que coloca à liderança sempre no topo da instituição.

Para Dionne \& Roger (1997), o verdadeiro estrategista do século XXI é aquele que concebe a organização como o conjunto de pessoas que a modelam, e que se assume como um negociador do cotidiano capaz de inserir esse conjunto em um processo de aprendizagem e de mudança permanentes. Dotado de uma visão clara de seu projeto de empresa, este estrategista deveria ser capaz de animar sua organização, dividindo a sua visão com a comunidade e favorecendo o livre desenvolvimento do potencial humano.

Peter Senge tem se notabilizado por suas análises sobre a liderança. Em O Novo Trabalho do Lider (1997), o autor procura caracterizar os requisitos da liderança da organização que aprende, as novas habilidades que ela deveria incorporar, referindo-se, ainda, a algumas ferramentas de desenvolvimento da liderança.

O líder deveria ser encarado, segundo o autor, como projetista, professor e regente. No exercício do primeiro papel, a liderança se envolve como projetista dos ideais e propósitos da organização e, de sua tradução prática, das políticas e estratégias, construídas coletivamente. Se a responsabilidade primária da liderança é com esse planejamento, isto não quer dizer que esse ato seja solitário. $\mathrm{O}$ termo construção coletiva sugere conceber o processo de planejamento das políticas e estratégias como um processo de aprendizagem organizacional ampla. Citando Mintzberg (1982), Senge (1997) assume que esse planejamento não pode ser visto como um esquema racional elaborado no plano abstrato e implementado em toda a extensão da organização, mas como um fenômeno emergente. Organizações de sucesso "fabricam sua estratégia", uma vez que estão continuamente aprendendo com as constantes mudanças na condições dos negócios, ponderando o desejável e o factível. O segredo não está em obter a 
estratégia certa, mas sim em promover o pensamento estratégico. A escolha da ação individual é apenas parte da necessidade do criador da política. $\mathrm{O}$ mais importante é a necessidade de conseguir enxergar a complexidade e de formular conceitos e visões de mundo para lidar com essa complexidade. A promoção de um ambiente de aprendizagem através da difusão do pensamento estratégico seria uma das funções essenciais da liderança.

O líder como professor corresponde à visão do mentor, do guia, do facilitador. Os objetivos fundamentais deste professor seriam trazer à tona e ajudar a reestruturar os modelos mentais e visões da realidade das pessoas, bem como promover o pensamento sistêmico, no sentido daquele pensamento voltado para as causas estruturais ou profundas dos fenômenos.

O líder como regente das pessoas e da missão organizacional é uma instância que se compenetra dos ideais de alta responsabilidade que caracterizam uma organização que aprende e que se coloca a serviço dos interesses superiores da organização. O conceito de uma liderança que presta serviços (servant leadership) é o oposto da liderança egocêntrica.

Entre as habilidades que a liderança deveria desenvolver, Senge cita:

- a construção de visões compartilhadas, implicando alguns requisitos: o líder deve saber comunicar sua visão e pedir apoio, no sentido de conferir se ela merece o comprometimento dos outros e de questionar seu ponto de vista, assumindo uma construção interativa; as visões pessoais devem ser estimuladas e não anuladas; a construção da visão é um processo contínuo, que não se deixa apreender pela figura da "declaração da missão" em reuniões especiais, mas que corresponde à difusão do pensamento estratégico capaz de apoiar o questionamento quotidiano do que realmente queremos conseguir em cada circunstância prática; a liderança deve poder combinar visões extrínsecas (do tipo “derrotar um oponente”) com visões intrínsecas (criar um novo produto, um novo padrão de satisfação de necessidades); a liderança deve saber distinguir visões positivas (alicerçadas em aspirações) e negativas (baseadas no medo), fortalecendo as primeiras.

- Trazer à tona e testar modelos mentais, implicando alguns requisitos: a possibilidade de perceber saltos de abstração, questionando generalizações; equilibrar indagação e argumentação, assumindo que situações complexas exigem um aprendizado cooperativo; distinguir a teoria esposada (o que diz que se faz) da teoria em uso, assumindo que a distância entre o declarado e o real em uso implícito é crítica para o aprendizado; reconhecer e dissipar rotinas defensivas, concebidas como ações que previnem as pessoas e unidades de vivenciarem embaraços ou ameaças e de identificar e modificar as causas dessas ameaças (Argyris, 1992). 
- Desenvolver o pensamento sistêmico, que corresponde a: enxergar interrelações, não coisas, processos, não fotos instantâneas; ir além das acusações, assumindo que a fonte das falhas não são as pessoas, mas os sistemas; concentrar-se na complexidade dinâmica (saber relacionar causas e efeitos distantes no tempo e espaço e distinguir conseqüências remotas) e não na complexidade de detalhes; concentrar-se, em termos da ação, em áreas de alta alavancagem; evitar soluções sintomáticas.

- Criar uma rede de proteção para a reflexão individual e coletiva, capaz de sustentar a possibilidade da inovação e da mudança. Aqui, a capacidade de garantir um tempo livre para a reflexão dos sujeitos organizacionais é fundamental.

Senge, também cita algumas ferramentas de desenvolvimento da liderança que passaram a ter destaque nas organizações que aprendem:

- A descoberta do arquétipo de sistema prevalecente: Senge sustenta que haveria uma relação geral precisável e mais ou menos recorrente de arquétipos de sistema (estruturas sistêmicas repetitivas ou formas de comportamento repetitivo que configuram padrões genéricos) e que a identificação do tipo característico de cada empresa em particular é um exercício importante de análise capaz de apontar para mudanças organizacionais significativas. A título de ilustração, um arquétipo bastante difundido é o da transferência de responsabilidade, que leva a protelar soluções estruturais em prol de um tratamento sintomático que só faz aprofundar ao longo do tempo a crise de uma organização.(para quem tem interesse em se aprofundar no conhecimento dos arquétipos, consultar Senge, 1998).

- Definir dilemas estratégicos: este nível de exercício refere-se à capacidade de evocar os dilemas ou de distinguir valores distintos e as vezes aparentemente conflitantes atrás das decisões(por ex. custo e qualidade). O objetivo do exercício é o mapeamento de onde os gerentes se vêem (mais perto de que valor) e de onde vêem a organização, e a busca de um sinergia possível entre valores, mediante uma simulação que implica usar um valor como contexto possível do outro, em pensar em termos de seqüência e não de instantes, de modo dinâmico etc.

- A coluna da esquerda de Chris Argyris: é um exercício construído a partir da seleção de uma situação específica que configura uma interação com os outros que funciona mal, no sentido de não gerar um aprendizado. Desta situação específica cada participante registra o dito ou declarado formalmente (na coluna da direita) e o modelo mental real (ou o nosso diálogo interno) na coluna esquerda. A confrontação dos exercícios gera um tipo de questionamento que pode ajudar a melhorar as interações do ponto de vista da aprendizagem. Esta ferramenta ajudaria a identificar e questionar 
saltos de abstração (pular dos dados às generalizações sem uma testagem adequada dos dados) e a discutir criticamente sobre as premissas (trazidas a tona) de nossas posições e comportamentos.

- Laboratórios de aprendizagem: Senge se refere à necessidade de combinar nesses laboratórios temas profissionais com dinâmicas interpessoais significativas, pois a aprendizagem é um fenômeno indivíduo-indivíduo e indivíduo-sistema, e concede um grande destaque ao desenvolvimento de jogos de simulação da dinâmica de sistemas, que correspondem a exercícios de prospectiva, e a determinados insights de estruturas profundas que causam problemas organizacionais (capacidade de problematização).

Concluiremos esta parte fazendo alusão a um autor nacional. Motta (1991) destaca três dimensões de habilidades e qualidades da liderança: organizacional, interpessoal e individual.

Sobre as habilidades organizacionais, o autor salienta:

- O bom conhecimento da missão e dos objetivos internos, para que estes possam ser comunicados, e das características da ambiência externa, de modo a facilitar a adequação da empresa à realidade existente.

- A capacidade de descoberta permanente e de processamento contínuo de problemas e soluções.

- A capacidade de articular, agregar e processar continuamente idéias e alternativas de ação para redefinir o sistema de autoridade e de responsabilidade, a partir de valores compartilhados.

- A capacidade de ter uma visão (intuição sobre o futuro) e de orientar-se em termos prospectivos.

Em relação às habilidades interpessoais, o autor destaca:

- A capacidade de aprender a aceitar as pessoas como elas realmente são e de reconhecer o valor positivo que elas têm.

- Estimular o contato direto permanente com as pessoas, aumentando a autoconfiança dos indivíduos e a confiança da liderança em cada um.

- Desenvolver as capacidades de comunicação e de negociação, reforçando o compartilhamento de informações, a interação permanente e a participação.

- Praticar um tipo de gestão ambulante, diminuindo a distância social.

A respeito das habilidades individuais, o autor considera que devem ser encaradas de maneira flexível, por serem passíveis de aprendizado ou não necessariamente inatas. Ele destaca algumas básicas como, o bom conhecimento de si mesmo (antes de qualquer outra), de suas potencialidades e limitações; a iniciativa; o otimismo; a persistência; a integridade e a autenticidade. Reforçando a dimensão subjetiva, o autor se detém na importância do ilógico e da intuição na 
gestão administrativa, que explicam o caráter as vezes pouco coerente e racional da mesma. Motta acrescenta que a intuição mistura elementos de racionalidade formal e informal e que esta se apóia fortemente na experiência acumulada pela liderança. Este destaque dado à dimensão subjetiva não formal ou racional da liderança opera aqui como um argumento importante para não omitir a natureza também individual da mesma.

Este autor sintetiza as qualidades da liderança, usando o Quadro 2:

Quadro 2 - Mitos e realidades sobre liderança.

\begin{tabular}{|l|l|}
\hline \multicolumn{1}{|c|}{ Liderança não é } & \multicolumn{1}{c|}{ Liderança é } \\
\hline 1. Mágica ou mistério & 1. Habilidade humana e gerencial \\
2. Propriedade de pessoas eminentes & 2. Alcançável por pessoas comuns \\
3. Fruto de qualidades especiais inatas & 3. Produto de habilidades e \\
4. Panacéia para todos os problemas & conhecimentos aprendidos \\
5. Uso do poder pessoal para garantir & $\begin{array}{l}\text { 4. Forma de comunicação e articulação } \\
\text { seguidores ou propósitos pessoais }\end{array}$ \\
$\begin{array}{l}\text { de uma missão e de futuros alternativos } \\
\text { 5. Uso do poder existente para garantir o } \\
\text { alcance de propósitos comuns }\end{array}$ \\
\hline
\end{tabular}

Fonte: Motta, 1991.

Podemos depreender que o novo paradigma de liderança acentua a necessidade de que esta tenha uma clara visão estratégica e atributos de comunicação e de negociação que a facultem a operar mais como fator de mobilização do que de imposição. É importante salientar que esta disponibilidade de uma visão privilegiada para a mudança (como vários autores culturalistas reafirmam) não pode ser entendida como uma visão personalista e manipuladora de liderança, mas como um olhar posto a serviço da argumentação crítica (para além da persuasão de base emocional) e construído na base da escuta ativa dos outros e, principalmente, da cultura.

\section{Referências Bibliográficas}

ARGYRIS, C. Enfrentando Defesas Empresariais (facilitando o aprendizado organizacional). Rio de Janeiro: Campus, 1992.

BENNIS, W. A Nova liderança. In: Grupo HSM Management (orgs.). Liderança e Gestão de Pessoas. Autores e Conceitos Imprescindiveis. São Paulo: Publifolha, 2001. 
BENNIS, W. \& BIEDERMAN, P. W. Os Gênios da Organização (As forças que impulsionam a criatividade das equipes de sucesso). Rio de Janeiro: Campus, 1999.

BENNIS, W. \& NANNUS, B. Diriger. Paris: InterEditions, 1985.

COVEY, S. R. Liderança Baseada em Princípios. Rio de Janeiro: Campus, 1994.

CRÉMADEZ, M. \& GRATEAU, F. Le Management Stratégique Hospitalier. Paris: Inter Éditions, [1992] 1997.

CROZIER, M. LEntreprise à l'Écoute. Paris: InterEditions, 1989.

CROZIER, M. \& FRIEDBERG, E. L'Acteur et le Système. Paris: Éditions du Seuil, 1977.

CROZIER, M. \& SÉRIEYX, H. Du Management Panique à l' Entreprise du XXIe Siècle. Quebec: Máxima, 1994.

DIONNE, P. \& ROGER, J. Le Stratège du XXI Siècle - Vers une Organization Apprenante. Montreal/Paris/Casablanca: Gaetan Morin, 1997.

FISCHER, R. M. \& FLEURY, M .T (orgs.). Cultura e Poder nas Organizações. São Paulo: Ed. Atlas, 1996.

FLEURY, M. T. L. et al. Arqueologia teórica e dilemas metodológicos dos estudo sobre cultura organizacional. In: MOTTTA, F.P.C. \& CALDAS, M. (orgs.) Cultura Organizacional e Cultura Brasileira. São Paulo: Atlas, 1997.

FLORES, F. Inventando la Empresa del Siglo XXI. Santiago: Hataché, 1989.

HABERMAS, J. Entrevista à Folha de S. Paulo (17/05/1995). Folha de S. Paulo, Ilustrada, p. 54-55. São Paulo, 17/05/1995.

HABERMAS, J. Teoria de la Acción Comunicativa. Madri: Taurus, 1997.

LIMERICK, D.; PASSFIELD, R. \& CUNNINGTON, B. The Learning Organization, 1(2), MCB University Press, 1994.

MAANEN, V. V. Processando as pessoas - estratégias de socialização organizacional. In: FISCHER, R. M. \& FLEURY, M .T (orgs.). Cultura e Poder nas Organizações. São Paulo: Ed. Atlas, 1996.

MATURANA, H. Emogões e Linguagem na Educação e na Política. Belo Horizonte: Editora UFMG, 1998.

MATUS, C. Sobre la teoría de las macroorganizaciones, Revista PES, n. 3, Santafé de Bogotá, 1994.

MINTZBERG, H. Structure e Dynamique des Organisations. Paris: Éditions d'Organisation, 1982. 
MOTTA, F. P. C. \& CALDAS, M. Cultura Organizacional e Cultura Brasileira. São Paulo: Atlas, 1997.

MOTTA, P. R. Gestão Contemporânea: a ciência e a arte de ser dirigente. Rio de Janeiro: Record, 1991.

PETTIGREW, M. A cultura das organizações é administrável? In: FISCHER, R. M. \& FLEURY, M .T (orgs.). Cultura e Poder nas Organizações. São Paulo: Ed. Atlas, 1996.

RIVERA, F. J. U. A gestão situacional em saúde e a organização comunicante. Cadernos de Saúde Pública, RJ, 12 (3): 357-372, jul-set, 1996.

SCHEIN, E. Guia de Sobrevivência da Cultura Corporativa. Rio de Janeiro: José Olympio, 1999.

SENGE, P. A Quinta Disciplina. Arte eprática da organização que aprende. São Paulo: Best Seller, 1998.

SENGE, P. et al. A dança das mudanças. Os desafios de manter o crescimento e o sucesso em organizações que aprendem. Rio de Janeiro: Zumble/Campus, 2000.

STARKEY, K. Como as Organizações Aprendem Relatos de Sucessos das Grandes Empresas. São Paulo: Zumble/Futura, 1997.

STRATEGOR. Stratégie, Structure, Décision, Identité.Politique Générale d'Entreprise. Paris: Dunod Ed., 1997.

THÉVEnEt, M. Audit de la Culture d'Entreprise. Paris: Les Éditions d'Organisation, 1986.

THÉVENET, M. La Culture d'Entreprise. Paris: Presses Universitaires de France, 1993.

THÉVENET, M. A cultura de empresa hoje em dia. Revista de Administração, v.26, n.2, p.32-39, abril/junho 1991. 
 \\ ComUnicaÇÃo e NEGOCIAÇÃo GERENCIAL}

$A$ necessidade de gerir organizações profissionais, entre as quais se situam as de saúde, obriga a pensar os termos comunicação e negociação como elementos decisivos de um determinado modelo de gestão. Usamos o termo organização profissional no sentido dado por Mintzberg (1982), como característico de um tipo organizacional dominado, do ponto de vista da possibilidade de controle dos processos de trabalho e das decisões administrativas, pelos centros operadores (com uma grande dose de autonomia destes), e em que a padronização produtiva e as formas de coordenação são dependentes, em boa parte, de conhecimentos, habilidades e formas de status adquiridos fora da organização nas associações respectivas e nas universidades.

Em trabalho anterior (Rivera, 1995), analisando as características dessas organizações, tais como a não-padronização absoluta de muitas relações de insumo-produto e a imprecisão de seus resultados, afastamos a possibilidade de uma gerência tradicional, de uma normatização "mecanística" de processos.

Considerando: a) o envolvimento em uma malha intrincada e variável de uma ampla gama de serviços e de categorias profissionais, vinculados a processos em permanente diversificação; b) o corporativismo dessas categorias que conspira contra a idéia de equipe, tão cara à prestação de serviços sanitários; c) a necessidade de definir coletivamente mecanismos de avaliação de resultados (e de responsabilidades); d) o caráter interativo do trabalho finalístico etc., aderimos a um tipo de modelo de gestão comunicativo, negociativo, consensual.

O entendimento da administração pública como uma arena de interesses variados de atores, em disputa por uma dada hegemonia, reforça, ainda, a idéia de aprimorar a comunicação interna como meio para a cristalização de pactos normativos capazes de coerir essas organizações. A característica básica do poder nas organizações profissionais, não concentrado, mas fortemente comparti- 
lhado ou distribuído pelos vários centros operadores e núcleos profissionais e operativos, reforça um sistema de gestão que tem no ajustamento mútuo e na negociação de interesses um dos seus traços marcantes.

Nesse contexto, a necessidade de uma discussão sobre formas de aprimoramento da comunicação e da capacidade de negociação dos agentes organizacionais adquire uma clara relevância.

Apresentamos, aqui, algumas das bases do modelo de negociação da Harvard Law School e avançamos algumas possibilidade de complementação do mesmo a partir de enfoques lingüísticos ou comunicativos. Precedemos esta análise de uma revisão concisa das formas de negociação e de negociador, pois essa análise ajuda a melhor circunscrever o tipo específico de modelo que sustentamos.

\section{Tipos de Negociação e de Negociador}

Matus (1994) distingue três tipos de negociação:

- Cooperativa: baseada em interesses distintos e objetivos comuns, dando lugar a um jogo de soma positiva.

- Conflitiva, baseada em interesses opostos, dando lugar a um jogo de soma 0.

- Mista, baseada em interesses opostos combinados com interesses distintos, dando lugar a uma negociação mista.

Para este autor, a escolha do tipo de negociação vem determinada pelo tipo de objeto da negociação. Assim, por exemplo, as questões envolvendo uma comunidade econômica suscitam, em geral, formas de negociação mistas; as cooperativas econômicas são mais afetas a formas cooperativas de negociação; e finalmente, a negociação da compra de um imóvel envolve formas mais conflitivas, onde guardar segredo sobre informação vital é uma estratégia natural.

É importante que se diga que Matus situa a negociação como uma possibilidade de meio estratégico, ao lado da autoridade, da persuasão e do conflito.

Chalvin (1997) distingue a negociação do entendimento e da autoridade. A autoridade corresponderia, como defende Matus, à imposição hierárquica de diretrizes, pressupondo a legitimidade da hierarquia e poderes desiguais. A autoridade poderia, no entanto, deslizar para a violência coercitiva. $O$ entendimento suporia poderes iguais e uma comunidade absoluta de interesses. Para este autor, a negociação comportaria um processo crítico de articulação de poderes diferentes e complementares, com base na tolerância e na pluralidade. Situada entre a autoridade e o entendimento natural, a negociação tipifica um universo de poder flutuante. 
Chalvin identifica vários enfoques de negociação:

- O enfoque persuasivo: o negociador aqui preza a competição e as negociações difíceis. Defende seu ponto de vista com força, gosta de ganhar. Estabelece prazos para a negociação, seu discurso é avassalador visando a reduzir o outro. Sempre pede mais para obter um pouco menos. Há, neste caso, um sentido de manipulação. Este estilo pode comprometer claramente a relação interpessoal envolvida na negociação.

- O enfoque cooperativo: o negociador pertinente se preocupa com seu interlocutor e busca encontrar um objetivo comum, elaborando em conjunto uma solução nova. É o jogo do tipo ganhar-ganhar. Há uma opção pela comunicação, em detrimento da agressividade e da disputa. Há a predisposição a compartilhar o poder. A preservação da relação é o objetivo supremo, podendo até comprometer até a obtenção de ganhos.

- O enfoque considerado ideal: nesta alternativa, persegue-se a resolução de problemas, a adesão completa das duas partes a uma alternativa de solução duradoura, construída ao longo de uma discussão profunda. Esta opção dificilmente se diferencia da anterior, a não ser pela idealização de uma solução perfeita, que implique o máximo de ganho e de relação, possibilidades às vezes conflitantes.

- O enfoque pela conciliação: é um estilo adaptativo, lento, realista, de soma progressiva de interesses, na linha dos arranjos provisórios. É um estilo camaleônico de articulação preocupado com a obtenção de pequenos resultados. Trata-se de uma política pragmática de resultados, que não produz soluções perfeitas e duradouras.

- O enfoque procedural: corresponde a um enfoque burocrático, ritualístico, de produção de acordos basicamente formais, versando sobre procedimentos e não sobre conteúdos substantivos.

Para este autor, o que existe, na prática, é uma combinação de enfoques de negociação, com alguns apresentando uma maior capacidade de convergência. Da mesma maneira, assim como em Matus, o autor sustenta que é necessário dosar ou combinar, de maneira adequada à realidade, as estratégias maiores de autoridade, entendimento e negociação.

Zajdsznajder (1988) estabelece uma discussão sumamente interessante sobre duas formas básicas de negociação: a negociação baseada na argumentação e aquela baseada na persuasão. Para ele, a base da argumentação é a comunicação crítica. Esta implicaria a apresentação de razões ou de uma base de prova para as teses defendidas e na obtenção de um convencimento legítimo em relações a estas razões, que poderão ser sucessivas. 
Na persuasão, haveria um tipo de convencimento não crítico, não baseado em razões. O acordo poderia ser obtido com base na adesão pura e simples de uma parte a um político poderoso capaz de oferecer segurança; com base em um discurso agressivo ou manipulador, hipnótico, que se adapta a cada público; e com base na exploração das emoções. Esta caracterização coincide com a de Matus, que diferencia a negociação da persuasão tendo em vista que, na primeira, haveria a disposição de fazer concessões, ao passo que, segunda haveria uma total cooptação.

O modelo escolhido como opção mais promissora, neste trabalho, é o da negociação cooperativa que visa, dentro do possível, ao ideal, e este modelo estaria baseado prioritariamente na argumentação crítica. O modelo de Negociação de Harvard estaria situado nesta faixa. Na linha de Zapiola (1992), uma ressalva importante a ser feita ao método está relacionada à sua denominação: Como Chegar ao Sim - a Negociação de Acordos sem Concessões. Um método argumentativo do tipo ganhar-ganhar não comportaria a não realização de concessões como sua característica.

Considera-se, aqui, a inevitabilidade de uma interação argumentativa-persuasiva, tal como reconhecida por Zajdsznajder. Preconiza-se a subordinação de um componente persuasivo da negociação, difícil de afastar, à argumentação crítica. E, por fim, sustenta-se a idéia de que a determinação da situação em jogo sobre o tipo de enfoque negociativo não é absoluta, de modo a podermos priorizar voluntariamente a busca permanente de um ideal de enfoque cooperativo.

\section{O Modelo de Negociação de Harvard Revisitado}

Este modelo, consubstanciado em Como Chegar ao Sim - a Negociação de Acordos sem Concessões (Fisher \& Ury, 1985) e em Como Chegar a um Acordo (Fisher/ Brown; 1990), também é conhecido como o método de negociação a partir de princípios ou em função do mérito. É visto como uma alternativa à negociação suave, em que o negociador, para evitar o conflito, limita-se a concessões unilaterais, e/ou à negociação áspera, em que o negociador acirra o conflito defendendo posições extremas na expectativa de derrotar o interlocutor.

O modelo consta de quatro elementos básicos:

- Separar o relacionamento da substância do problema, trabalhando o relacionamento interpessoal como um interesse particular do processo de negociação.

- Negociar a partir dos interesses e não de posições. 
- Buscar opções variadas de ganho mútuo através de um processo criativo.

- Negociar antes de mais nada os princípios ou padrões objetivos a partir dos quais a negociação pode ser possível.

\section{A questão do relacionamento}

Trabalhar o aspecto do relacionamento interpessoal implica prestar atenção a três dimensões: a percepção, a emoção e a comunicação.

Em relação à percepção, o método faz uma série de recomendações, que relacionaremos a seguir:

- Considerando que a percepção é situacional, que não há verdade absoluta, que tendemos a ver aquilo que queremos ver em função de nossa tradição, é indispensável tentar ver como o outro vê. Isto implica colocar-se no lugar do outro. O marco do "como se" é uma técnica necessária: como veríamos uma dada situação se estivéssemos no lugar do outro?

- É importante procurar não deduzir as intenções dos outros de nossos próprios medos. Isto significa a necessidade de não atribuir a priori a pior das interpretações ao que o outro lado diz ou faz. Este tipo de "cegueira situacional" pode levar a desprezar idéias novas e interessantes no sentido de um acordo e a ignorar mudanças sutis de posição.

- É fundamental não culpar o outro por seu problema. A atribuição direta de culpa, mesmo que justificada, é geralmente contraproducente. Aqui há um problema de saber comunicar. A título de ilustração, há uma diferença entre os dois seguintes enunciados: (a) "Sua companhia é totalmente indigna de confiança. Todas as vezes que vocês fazem a manutenção de nosso gerador giratório aqui na fábrica, fazem um trabalho de péssima qualidade e ele torna a quebrar"; e, (b) "Nosso gerador giratório, cuja manutenção vocês costumam fazer, voltou a quebrar. Isto soma três vezes no mês passado. $\mathrm{Na}$ primeira vez, ficou enguiçado por uma semana inteira. A fábrica precisa de um gerador que funcione. Quero sua opinião sobre como podemos minimizar nosso risco de falhas no gerador. Será que devemos mudar de empresa de manutenção, ou o que vocês sugerem". Atribuir culpa enreda firmemente as pessoas com o problema, gera uma resistência no plano interpessoal que compromete a negociação do problema. É claro que o segundo enunciado é bem mais positivo.

- É importante considerar todas as percepções do outro lado, de cada um. Alguns interesses tratados como sem importância, no sentido de não se tornarem em obstáculos a um acordo, podem, se bem explorados, criar áreas de afinidade ou de acordo capazes de ajudar a um acerto mais geral. 
- Agir, em determinadas oportunidades, de maneira contraditória às percepções do outro, pode contribuir para aparar arestas e abrir espaços para acordos. A inesperada visita de Anwar Sadat, presidente do Egito, a Jerusalém, em 1977, é um bom exemplo disto. Em vez de agir como aquele inimigo declarado, Sadat age como um parceiro. Este passo dramático contribuiu, sem dúvida, para a assinatura de um tratado de paz entre Egito e Israel.

- A realização de qualquer acordo subentende a participação do outro desde o início do processo. É importante dar-lhe um interesse no resultado, certificando-se de que ele participa do processo. Por exemplo, grande parte da legislação anti-apartheid, formulada apenas por legisladores brancos, caiu no descrédito, porque estas medidas foram entendidas pelos negros como mais uma afirmação da "opressão do homem branco". A melhor maneira de caracterizar esta recomendação é assumir que o processo em si é o real produto da negociação.

- É fundamental, ainda, preparar os termos de um acordo, sobretudo daquele que implica desvantagens para o outro, de maneira tal que não violente os valores, os princípios e a auto-imagem dos outros negociadores. Redigir a substância do acordo de modo tal que o resultado pareça justo ajudará à posição dos outros, à defesa dessa posição perante eventuais cobranças das autoridades superiores. Isto corresponde ao conselho: "salvar as aparências: torne suas propostas compatíveis com os valores do outro". Tal preocupação fortalece a possibilidade de um relacionamento futuro positivo.

Em relação ao aspecto emoção, o método, além de destacar a importância crucial dos sentimentos relativamente as próprias palavras, no sentido de poderem comprometer significativamente o processo de acordo, aconselha a absoluta transparência.

Explicitar as emoções e reconhecer sua legitimidade é absolutamente normal e necessário. Libertar-se do fardo das emoções não exprimidas aumenta significativamente a probabilidade de as pessoas trabalharem no problema. Isto subentende a necessidade de deixar que o outro desabafe, de criar um clima que propicie isto. Uma regra de ouro se aplica aos casos de reação agressiva: escutar em silêncio, não reagir, pedir que o outro prossiga; somente uma pessoa teria o direito de se zangar de cada vez.

A utilização de gestos simbólicos que expressem carinho, solidariedade, preocupações pelo outro, minoram as possibilidade de um clima hostil.

Em situações de um estado emocional negativo, a utilização de técnicas de visualização pode ser útil. Colocar-se em "estado de recurso" corresponde a visualizar cenas de negociação do passado em que estivemos plenamente realizados, motivados, envolvidos em processos positivos. Da mesma maneira, poderíamos 
concentrar-nos no estado emocional em que gostaríamos que nosso parceiro estivesse e adotar este estado. O outro pode seguir o nosso exemplo, contagiarse, buscar recursos positivos.

Uma variante da técnica do "como se" é a dissociação visual-cinestésica. Aplica-se a situações em que o parceiro da negociação está encurralado em um estado interno negativo ou processo de autoconvicção negativa, fechado em posições, sem poder avançar. A idéia implícita é desconectar o parceiro desse estado de concentração em sentimentos e diálogos internos, no nível da representação cinestésica, através do recurso da visualização. Considera-se que colocar o interlocutor como observador da situação, mudando sua forma de representação sensorial, é uma forma de mudar seu estado. Esta sorte de desvio da atenção permitiria à pessoa tomar distância em relação a seu problema - assumir uma metaposição. Pedir para que a pessoa envolvida imagine o que veria na situação que está vivendo se estivesse no lugar de outrem é uma forma de recurso. Em geral, trata-se de formular perguntas que façam com que aquela pessoa olhe a situação, diga o que vê realmente. Explorar a representação visual do objetivo dessa pessoa, induzi-la a fazer uma imagem construída do mesmo, insere-se nessa lógica que opera como técnica simples de criatividade. Isto corresponde em geral a assumir o outro não como um inimigo, mas como parceiro, sócio do processo de negociação.

O aspecto da comunicação é o terceiro elemento do trabalho voltado sobre a relação. Sem comunicação não há negociação. Haveria três grandes problemas de comunicação:

- Não falar para o outro interlocutor, mas para uma platéia.

- Não escutar, por estar concentrado nos lances de pensamentos futuro.

- Os mal-entendidos da comunicação, considerando compreensões diferentes de termos (por motivos culturais) ou um tipo de comunicação discursiva, indireta, imprecisa.

As recomendações pertinentes são as seguintes:

- Escutar e registrar ativamente o que esta sendo dito. Perguntar, solicitar esclarecimentos diante de ambigüidades é fundamental, assim como reproduzir positivamente, de maneira resumida, os termos da colocação do outro. O outro, ao se aperceber que sua proposta está sendo entendida, ficará muito satisfeito. $\mathrm{O}$ ideal é reproduzir a proposta do outro em melhores termos do que a formulação originária. Ajudar a precisá-la melhor. Nesta operação, não se emitiriam julgamentos, comentários críticos. Fica extremamente mais fácil, posteriormente, questionar a colocação do outro, quando se obtém um acordo inicial construtivo sobre o que o outro está querendo dizer. A utilização dos mesmos predicados que o outro emprega cria 
uma sintonia fina, um rapport, uma aproximação quase que "fisiológica". O back tracking ou reprodução resumida da proposta do outro utilizando o tipo de predicados por ele utilizados é uma técnica bastante utilizada no campo da psicologia, ajudando a harmonizar, a comunicar. A Psicologia Comportamental parte da hipótese de que, na representação sensorial da experiência, as pessoas utilizam predominantemente uma determinada forma de representação, que é o sistema sensorial que estaria sob o foco da conscientização. Assim, fala em pessoas predominantemente visuais ou auditivas ou cinestésicas. A linguagem dos seres humanos refletiria essa predominância. As pessoas visuais utilizariam predominantemente ou muitos predicados visuais (à primeira vista, esclarecer, ilustrar, visivelmente, evidentemente, etc.) e assim por diante. Estes tipos apresentariam, ainda, determinadas características de comportamento não-verbal ou uma determinada fisiologia. Os cinestésicos, ilustrando, teriam uma respiração profunda, ampla; seus movimentos mimetizariam as palavras; a voz seria grave, o ritmo lento com muitas pausas etc. Esta construção é utilizada em vendas. Procurar vender um produto pelas suas qualidades visuais a uma pessoa cinestésica é uma péssima estratégia. Uma pessoa deste tipo poderia ficar sensibilizada por qualidades como a textura, o conforto etc. A aplicação desta técnica ao campo da negociação é óbvia. Convencer fica mais fácil se utilizarmos o tipo de predicados adequados à forma de representação primária do parceiro da negociação. Portanto, é absolutamente necessário traduzir nossos argumentos na linguagem do outro. Esta técnica pode ser reforçada pelo espelhamento que implica refletir o comportamento não verbal dos participantes de uma negociação de modo a criar uma sintonia, uma aproximação inconsciente (voz, gestos, postura, respiração etc.). Além de ajudar a criar uma relação mais harmoniosa, o espelhamento é considerado um instrumento que precede à possibilidade de conduzir o parceiro (leading).

- É importante falar para ser entendido. Recomenda-se empregar meios privados e confidenciais de comunicação, grupos relativamente pequenos, para evitar a situação de ter de afirmar-se diante de terceiros, e utilizar uma comunicação direta, concisa, não excessiva. Isto subentende falar com objetivos claros, saber o que se quer comunicar.

- Fale sobre você e não sobre o outro. Condenar as motivações do outro leva a inevitáveis questionamentos. É mais conveniente descrever o impacto de um problema sobre você do que analisar o problema do ponto de vista da responsabilidade do outro. Dizer: 'sentimo-nos discriminados', em lugar de 'você é racista' faz uma grande diferença. 


\section{Negociar interesses e não posições}

O segundo passo decisivo do modelo em pauta consiste em evitar a barganha posicional, pois esta põe em conflito a relação com a substância do problema. Concentrar-se nas posições ou nas respostas específicas que você quer obter, de maneira egocêntrica, leva a situações extremadas, de estrangulamento (da própria relação). Antes disso, é necessário conciliar interesses, enquanto os fundamentos (ou causas) de uma posição (desejos, necessidades, temores, valores).

Fisher \& Ertel (1997) demonstram a diferença entre posições e interesses. Se estamos inseguros sobre se algo é uma posição ou um interesse, devemos determinar se há mais de uma maneira de satisfazê-lo. Se não houver, como no caso de 'eu exijo um carro da empresa', trata-se de uma posição. Em contrapartida, se houver várias maneiras de satisfazer uma exigência (como no caso de ‘quero transporte para o trabalho' ou 'quero mais status na empresa'), é provável que seja um interesse.

Para descortinar os interesses subjacentes, é necessário aplicar a si próprio e/ou ao interlocutor a técnica do por quê: por que o outro assume uma dada posição ou por que o interlocutor não assumiria uma determinada posição? (que seria aquela que corresponde à posição que nós esperaríamos ou gostaríamos que ele tomasse). As decisões ou motivações oriundas do uso sistemático do por quê podem ser hierarquizadas, através de perguntas sucessivas que vão descortinando novas motivações envolvidas nas primeiras a aparecer. As últimas motivações em geral são as mais decisivas.

Em alguns modelos de negociação (Kluczny, 1993), mais ligados à mediação, à arbitragem, o ponto de partida consiste na definição de um meta-objetivo que una as partes, de um objetivo compartilhado, do que se denomina a base de resultados de um acordo.

Este ponto pressupõe que ambas as partes definam seu objetivo no processo de negociação. A definição do meta-objetivo comum resulta de perguntar a cada parte o benefício a ser alcançado com o objetivo específico. Sucessivas perguntas no sentido de 'para que finalidade'? podem levar à definição da chamada base de resultados.

Em geral, os meta-objetivos correspondem lingüisticamente a nominalizações. As nominalizações são palavras que entram no lugar de um substantivo na sentença, mas não podem ser tocadas, sentidas, nem ouvidas. Não são tangíveis. Palavras como amor, felicidade, curiosidade são exemplos. São palavras abstratas, genéricas, sem especificidade em termos de conteúdo. Prestam-se subjetivamente a múltiplas interpretações e não suscitam oposição. Por isso facilitam acordos gerais. São fenômenos lingüísticos que transformam um processo dinâmico em um acontecimento abstrato, coagulado (amar em amor, por exemplo). 
Estes fenômenos nos impedem de saber o conteúdo concreto, a forma concreta do acontecer de tal acontecimento. Nesta medida, são considerados fenômenos de distorção da experiência ou de substituição de dados sensoriais.

Dado um determinado meta-objetivo e definidas algumas condições básicas para que se decida no processo negociativo, preconiza-se a aplicação sistemática da técnica do "desafio de relevâncias". Isto corresponde a lembrar, o tempo todo, em que medida uma determinada discussão é relevante do ponto de vista da base de resultados da negociação. Desta maneira, economiza-se tempo, evitam-se caminhos colaterais e se organiza o processo de alcançar objetivos concretos.

A premissa implícita na possibilidade de negociar interesses é a de que por trás de posições opostas, além de interesses conflitantes, haveria interesses comuns e interesses diferentes, não necessariamente incompatíveis.

A idéia seria, então, ampliar a faixa de acordo em torno dos interesses comuns e em explorar em profundidade a possibilidade de conciliar ou harmonizar os diferentes, de modo a criar formas de afinidade que aplainem o caminho para uma negociação mais geral. É necessário considerar, ainda, que um mesmo lado pode ter interesses múltiplos, oferecendo a possibilidade de acordos com segmentos desse lado. Algumas necessidades humanas básicas podem ser consideradas interesses, como: a segurança, o bem-estar econômico, o sentimento de pertença, o reconhecimento, o controle sobre a própria vida.

A título de ilustração, citamos o tratado de paz egípcio-israelense esboçado em Camp David em 1978. Israel tinha ocupado a península do Sinai na Guerra dos 6 dias em 1967 e não abria mão de uma parte do Sinai. O Egito queria a devolução completa. Por inúmeras vezes, as duas partes insistiam em suas posições de maneira recalcitrante. Mapas e mapas mostrando possíveis fronteiras eram desenhados dividindo o Sinai, sem sucesso. A análise dos interesses possibilitou o acordo. Israel queria a segurança, não queria tanques egípcios na sua fronteira. O Egito queria a soberania, tendo em vista que, depois de anos de ocupação colonial por sucessivos povos, essa república tinha conquistado sua soberania total, valor político inestimável para sua população. Sadat e Begin concordaram com um plano que restituiria o Sinai à soberania egípcia e que desmilitarizaria amplas áreas, garantindo a segurança de Israel. A bandeira egípcia tremularia em todo o território, mas não haveria tanques egípcios perto da fronteira israelense.

Outra situação que se presta a uma ilustração das possibilidades de negociação de interesses, para além da barganha posicional, é a negociação do preço do aluguel de um imóvel. Haveria aqui interesses conflitantes. Maximizar/minimizar o preço do aluguel. A possibilidade de um acordo sobre o problema iria depender muito da negociação com base em outros interesses. Haveria exem- 
plos de interesses comuns, a explorar: ambos querem estabilidade (uma relação de inquilinato duradoura); ambos gostariam que o imóvel fosse bem conservado; ambos poderiam ter um interesse num bom relacionamento mútuo. É possível que elas tenham interesses não conflitantes, mas simplesmente diferentes, por exemplo: o inquilino talvez não queira lidar com tinta fresca e o proprietário não queira arcar com o custo da pintura; o proprietário gostaria de segurança de um pagamento antecipado pelo primeiro mês de aluguel e talvez queira recebêlo amanhã, ao passo que o inquilino, sabendo que o apartamento vale a pena, talvez não se importe com esse tipo de condição de pagamento. Os interesses conflitantes talvez possam ser melhor contornados, se houver acordo em relação a interesses comuns e divergentes. Por exemplo, a disposição do inquilino de arcar com o custo da tinta, caso o proprietário se disponha a assumir a pintura, junto com a aceitação, por parte do inquilino, de um pagamento antecipado. Eles podem se colocar de acordo, antes de mais nada, em relação à necessidade de uma boa conservação do imóvel, admitindo um esforço compartilhado, e à necessidade de cultivar um bom relacionamento futuro.

Em relação a este passo, a transparência é um imperativo. É necessário dar vida aos interesses, ser explícito. $\mathrm{O}$ ato de declinar dos interesses próprios deve ser acompanhado da busca de seu reconhecimento por parte do outro. Dar legitimidade aos próprios interesses é uma busca permanente e necessária, acima de tudo quando aqueles são considerados extremamente pertinentes. $\mathrm{O}$ reconhecimento dos interesses do outro como parte do problema é o avesso da situação anterior. Reconhecer os interesses do outro explicitamente, pode ser o primeiro passo para o reconhecimento dos próprios. O relato ou o reconhecimento dos interesses do outro pode ser precedido do enunciado 'corrija-me se eu estiver errado', o que já caracteriza uma posição de abertura. Se o outro não corrigir o relato de suas motivações, implica que ele aceita sua descrição da situação. É mais uma área de acordo. Mais uma forma de "fisiologia do sim".

Algumas outras algumas recomendações são interessantes.

- Colocar o problema antes da solução. No caso de uma obra de construção, cujos caminhões põem em risco a vida das crianças da localidade, a melhor forma de comunicar não seria, por exemplo: 'creio que vocês deveriam levantar uma cerca em torno da área do projeto dentro de 48 horas e limitar, imediatamente, a velocidade de seus caminhões a 25 quilômetros por hora. E lhe digo por quê.' Desta maneira, o interlocutor seguramente não escutará suas razões. Falar primeiro dos riscos para as crianças pequenas, fazendo com que o construtor se coloque na sua situação, reconhecendo o valor da vida humana, é uma forma mais efetiva de promover uma escuta construtiva. 
- Esquecer situações negativas do passado e concentrar-se no futuro ajuda a criar um relacionamento mais construtivo, assim como reenquadrar o passado, procurando e comunicando os aspectos positivos de situações de negociação anteriores de caráter crítico.

- Ter uma mente aberta a várias opções e não a uma única é outro imperativo óbvio.

- Ser rigoroso com o problema e afável com as pessoas cria o fenômeno da "dissonância cognitiva", segundo o qual as pessoas tendem a eliminar a incoerência - de efeitos desagradáveis - promovendo uma tendência para o acoplamento.

\section{Buscar opções criativas de ganho mútuo}

O terceiro passo do método se refere à necessidade de buscar primeiro soluções criativas e depois decidir (de não confundir o processo da invenção com a decisão mesma).

Haveria uma série de obstáculos à criatividade necessária à negociação:

- O julgamento crítico, prematuro, exacerbado, mata a criação, a imaginação.

- As pessoas acham que sua tarefa é estreitar o hiato entre as posições e não ampliar as opções disponíveis. Isto corresponde à busca de uma resposta única.

- Há, em geral, a pressuposição equívoca de um bolo fixo. A história da divisão da laranja, de duas crianças que disputam a mesma laranja e que concordam em parti-la ao meio, uma usando apenas a casca e jogando fora o sumo e a outra fazendo o contrário, desmistifica a idéia de que toda negociação é um processo que supõe um bolo fixo (que implica soluções do tipo ganhar/perder).

- Predomina, às vezes, a idéia de que 'resolver o problema dos outros é problema deles'. A abordagem unilateral do problema da negociação é outro obstáculo à possibilidade de opções várias de ganhos mútuos. Essa abordagem leva ao fechamento egocêntrico, reforça o segundo obstáculo, compromete a possibilidade da diversidade.

Diante deste quadro de obstáculos, surgem algumas recomendações:

\section{Separar a invenção das decisões}

A realização de sessões de sugestões livres (brainstorming session) ao interior do ator que negocia e/ou junto com os interlocutores é o método básico para 
estimular a criatividade. Algumas regras se impõem: mudar o ambiente da sessão; criar uma atmosfera informal; escolher um facilitador que garanta a simetria e a riqueza do debate; trabalhar com grupos nem muito grandes, para estimular a participação individual, nem muito pequenos, para proporcionar um intercâmbio estimulante; fazer com que os participantes sentem-se lado a lado (semicírculo), enfrentando o problema (delineado em um quadro), pois o físico reforça o psicológico, no caso, a busca cooperativa de opções; esclarecer as regras básicas, especialmente a regra da proscrição de críticas negativas; sugerir livremente; registrar as idéias a vista de todos, reforçando o sentimento de construção coletiva. A partir daí, sugere-se não cumprir à risca a regra da ausência de críticas, assinalando as idéias mais promissoras, tomar uma idéia promissora e aperfeiçoá-la e estipular um prazo para avaliar as idéias e decidir. Para "quebrar o gelo" em uma reunião com os interlocutores, é muito útil assumir o hábito de propor pelo menos duas alternativas ao mesmo tempo, para não criar a impressão do comprometimento com uma única idéia, ou apresentar antes do relato de alternativas de opções, idéias contraditórias das quais você visivelmente discorda.

\section{Ampliar as opções é essencial}

Ampliar as opções sugere uma metodologia que corresponde a um deslocamento das opções entre o particular e o geral. O ponto de partida consistiria em procurar processar (descrever e explicar) um problema e possíveis alternativas de solução. Neste ponto, pode tentar-se uma extrapolação que signifique identificar a abordagem geral ou a teoria geral que subjazem a uma idéia particular (uma opção) ou à própria explicação do problema. A seguir, procurar-se-ia discutir outras alternativas inerentes à mesma forma de abordagem geral. Uma boa forma de estimular a criatividade é observar problemas e propostas através do olho de diferentes especialistas.

Uma técnica de dissociação do interlocutor pode ser tentada, visando a demovê-lo de afirmações categóricas, expressas de maneira muito firme a respeito de alguma coisa. Aplica-se a situações críticas em que o interlocutor se prende a formulações fixas de caráter negativo. A lógica desta técnica consistiria em assumirmos novos papéis, através de uma simulação baseada na pergunta: 'O que eu pensaria desta questão caso fosse....?'. As novas dimensões positivas decorrentes dos novos papéis assumidos seriam introduzidas de surpresa no diálogo, de modo a ajudar a fixar a associação desta ou daquela dimensão (o elemento surpresa operaria como âncora). Estima-se que uma tendência natural das pessoas de fugir das situações desagradáveis atuaria como facilitador deste processo de ampliação de opções ou de reenquadramento positivo da situação, que não deixa de ser uma auto simulação de um encontro multidisciplinar. 
A relação de opções possíveis pode aumentar se forem consideradas 'versões mais leves' de enfrentamento de problemas, caso o acordo buscado venha revelar-se inatingível. A recomendação implícita é buscar acordos de pesos diferentes. Se vocês não puderem concordar quanto à substância, talvez concordem quanto ao procedimento (por exemplo, a necessidade de uma arbitragem). Do mesmo modo quando um acordo permanente não é possível, talvez um acordo provisório o seja. Se não for possível chegar a um acordo de primeira linha, talvez seja possível um acordo de segunda linha - concordando sobre o que discordam.

O condicional close ou moldura do "como se" pode ter uma utilidade na definição de acordos de pesos diferentes. Esta técnica se aplica a situações em que há objeções que dificultam o acordo. A idéia é procurar um acordo condicionado que pode ser sucessivo. Pergunta-se, à parte que objeta, se concordaria com uma dada proposta, caso as objeções que exprime fossem atendidas ou equacionadas. O objetivo é reforçar a "fisiologia do sim", pois esta facilita um acordo.

Modificar o alcance de acordo proposto, parcializando ou recortando a substância do problema, pode ensejar, ainda, acordos parciais, envolvendo um menor número de partes ou cobrindo apenas alguns aspectos.

\section{Procurar ganhos mútuos}

Esta questão está diretamente ligada com o passo 2 do método, que preconiza explorar os interesses comuns e harmonizar os diferentes (não incompatíveis). Chegar a um acordo através das diferenças subentende a existência de interesses que podem ser harmonizados. Isto pode ficar claro se considerarmos que há situações em que:

Um parte importa-se mais com:

- a forma

- as considerações econômicas

- o futuro imediato

- o precedente

- o prestígio, a reputação

- o equipamento pesado
A outra parte importa-se mais com:

- a substância

- as considerações políticas

- o futuro mais distante

- este caso

- os resultados

- a ideologia etc. 
A existência de crenças diferentes pode ser aproveitada, por exemplo, para convocar uma arbitragem. A valorização diferente do tempo entre vendedor e comprador possibilita acordos que impliquem planos de financiamento. O comprador paga mais caro pelo carro, se puder pagar mais tarde. $\mathrm{O}$ vendedor se dispõe a acertar um pagamento posterior, se puder obter um preço maior. $\mathrm{E}$ assim, há diversas situações de diferença que, ao invés de afastar, podem ser capitalizadas em termos de um acordo baseado na análise de interesses.

\section{Facilitar a decisão do outro}

Facilitar a decisão do outro se inscreve, na mesma linha de raciocínio da máxima: salvar as aparências do acordo. Mas também quer dizer que a negociação deve evitar o espírito de manipulação dos acréscimos deliberados com a finalidade de "criar mais espaço de negociação" e que deve considerar as conseqüências de um acordo x para o outro, procurando melhorá-las.

\section{Definir padrões para a negociação}

O quarto passo decisivo consiste em buscar, em insistir em critérios objetivos, em acertar padrões justos e independentes da vontade que podem balizar um acordo. O ponto de partida da negociação deveria ser este acerto. Entre estes padrões, podemos citar vários: o valor de mercado, o precedente, a opinião científica, os custos, um tribunal, padrões morais, a tradição etc. A busca por critérios justos pode referir-se a um conjunto de padrões que ajudem a dirimir a questão substantiva ou a procedimentos justos para resolver os interesses conflitantes. A antiqǘssima forma de dividir um pedaço de bolo entre duas crianças: uma corta e outra escolhe, é um exemplo de procedimento.

Uma variação da técnica do "um corta, o outro escolhe" consiste nas partes negociarem o que acreditam ser um acerto justo antes de decidir seus respectivos papéis. Isto se aplica aos casos de divórcio. Fazer revezamentos, tirar a sorte, deixar a decisão a cargo de um terceiro são outros exemplos interessantes. $\mathrm{O}$ importante é salientar que o ponto de partida é formular cada questão como a busca de critérios objetivos e buscar o acordo em torno deles.

Às vezes, um padrão de legitimidade não exclui a existência de outros. É importante considerar os padrões sugeridos pelo sócio da negociação e, por que não, eventualmente assumi-los. A melhor maneira de dirimir diferenças sobre o melhor critério é envolver mais pessoas, identificar qual é o padrão de maior aceitação social. Soluções de compromisso ou de divisão da diferença são acon- 
selháveis quando há dois critérios diferentes (preço de mercado e custo depreciado). O padrão usado pelas partes no passado pode ser, ainda, uma alternativa de resolução de diferenças.

Concluiremos esta parte fazendo alguns comentários rápidos (a partir de Como Chegar ao Sim) sobre como negociar com quem não quer jogar dentro das regras da negociação por princípios. O 'jiu-jitsu’ da negociação é uma forma de abordagem que se aplica nesses casos e que consiste em evitar jogar sua força diretamente contra a dele, usando de habilidade para esquivar-se (dos ataques) e direcionar a força do outro no sentido que lhe interesse. O objetivo é tentar trazer o outro para o campo da exploração dos interesses. As regras básicas dessa abordagem seriam:

- Não contra-atacar.

- Não atacar a posição do outro. É melhor aceitá-la como uma opção, procurando os interesses e princípios subjacentes e pensar em meios de aprimorá-los. Portanto, sempre olhe atrás da posição do outro.

- Faça com que o outro discuta hipoteticamente as conseqüências para nós da imposição de uma proposta defendida por ele. Não defenda suas idéias. Peça ao outro críticas e conselhos sobre uma idéia sustentada por você. Em vez de pedir-lhe que aceite ou rejeite uma idéia, pergunte-lhe o que há de errado nela: 'Qual de seus interesses esta proposta deixaria de levar em conta?'. Examine os julgamentos negativos do outro para descobrir-lhe os interesses subjacentes e aprimorar suas idéias desde o ponto de vista dele. Reelabore suas idéias à luz do que descobrir com ele, fazendo com que a crítica, antes um obstáculo ao processo de trabalhar pela obtenção de um acordo, transforme-se em um ingrediente essencial desse processo.

- Coloque o outro na sua posição e pergunte o que ele faria neste caso. É uma forma de canalizar críticas num sentido construtivo.

- Reformule os ataques a você como ataque ao problema. Exemplo: 'Quando o senhor diz que a greve demonstra que não nos importamos com as crianças, ouço nisso seu interesse pela educação das crianças. Compartilhamos desse interesse, elas são nossos filhos. Queremos que a greve termine e possamos voltar a educá-las. Que podemos fazer juntos'.

- As pessoas empenhadas nessa abordagem usam dois instrumentos-chave: a pergunta e o silêncio. As afirmações geram resistências, ao passo que as perguntas geram respostas. Elas, ademais de ajudarem a discernir melhor os interesses dos outros, distendem o ambiente (minoram o conflito) e ajudam a criatividade. O silêncio provoca um desconforto no outro, especialmente quanto este tem dúvidas. Leva à necessidade de falar mais, de completar afirmações que culminaram em um impasse. Gera desafios. 
É importante citar que, mais recentemente, Ury aprofunda esta estratégia (1991). Neste trabalho, o autor reafirma a necessidade de procurar trazer o interlocutor para o campo da discussão de interesses ou para a postura de solucionar problemas (desviando-o da postura ofensiva). Mais do que saber afirmar, o essencial aqui é saber fazer perguntas voltadas para a solução dos problemas, priorizando as perguntas em aberto (que são aquelas que não podem ser respondidas com um não). Correspondem a este tipo perguntas como: 'Por que você quer isso?', 'Por que você acha que isso seria justo?', 'Por que não fazer assim?', 'O que haveria de errado com esta abordagem?’, 'E se atendêssemos a essa exigência...?’ (condicional), 'Qual é o propósito desta política?', 'Como me aconselha a proceder?', 'Quem poderia estabelecer uma exceção?'.

Uma última técnica interessante da metodologia de negociação por princípios é a técnica do texto único, que supõe a mediação. Um mediador elabora um anteprojeto a partir do levantamento dos interesses de ambos os lados da negociação e discute este anteprojeto com cada parte em separado, de maneira alternada, reformulando-o sucessivamente em função das contribuições de cada lado, até que surge uma versão que mais agrade aos dois.

Fisher \& Ertel (1997), interessados na operacionalização prática do enfoque de negociação por princípios, propõem uma verdadeira "caixa de ferramentas para a preparação de uma negociação", que condensa a proposta em termos de formatos e que pode ser muito útil para nós. A partir da mesma, propomos o seguinte protocolo de preparação da negociação:

- Relacionar os atores do nosso lado e do outro afetados com o resultado da negociação.

- Listar, através da técnica ad-hoc, os interesses dos dois lados, procurando priorizá-los. Distinguir os interesses eventualmente comuns e distintos.

- Relacionar padrões “justos” de negociação em torno da questão substancial específica que deve ser respondida nesta negociação (critérios dotados de legitimidade), procurando identificar em que medida podem favorecer ou não nossa posição.

- Identificar algumas opções iniciais de ganho mútuo a partir do exame dos interesses e dos critérios legítimos de negociação.

- Identificar as alternativas dos dois lados, caso nenhum acordo seja conseguido. Ver os prós e contras. Explorar a possibilidade de melhorar minha(s) alternativa(s) e de tornar a(s) do interlocutor menos atraente(s).

- Usar a imparcialidade do processo para persuadir. Neste caso, procurar identificar em que medida processos persuasivos de obtenção de acordos sobre o processo (quando não se chega a um acordo substancial) podem ser aplicados (processos do tipo: eu corto, você escolhe; jogar uma moeda; chamar 
um especialista; deixar um árbitro decidir). E, tentar identificar situações em que o interlocutar se encontra na nossa situação, resgatando seus argumentos e vendo a possibilidade de aplicação na situação concreta (teste de reciprocidade).

- Em relação à comunicação e ao relacionamento:

- listagem dos problemas de relacionamento e das possíveis soluções;

- listagem de nossas suposições acerca das intenções e percepções do outro e do que podemos ouvir (ou do que os outros podem dizer) que possa questionar essas suposições;

- listagem de declarações que nós podemos fazer para expressar nossos interesses e de respostas possíveis da contraparte, visando reenquadrar ou redeclarar nossos interesses de modo que eles os ouçam melhor.

- Simular a situação em termos de um teatro lúdico de negociação, quantas vezes seja necessário, distribuindo os papéis (usar os elementos acumulados analiticamente).

- Listar conclusivamente no mínimo três opções consideradas de ganho mútuo.

\section{Comunicação, Criatividade e Exercício da Influência}

O modelo lingüístico da gramática transformacional de Chomsky (1965) supõe que, entre a representação sensorial primária da experiência e a representação lingüística, operam três formas de modelagem universal (filtros): a generalização, a distorção e a omissão. A generalização consiste em absolutizar uma experiência singular. A omissão é uma forma de negação da experiência, de silenciamento. A distorção é uma nova disposição ou uma nova organização dada aos conceitos, idéias ou objetos. É uma forma de substituição de dados sensoriais. Este metamodelo assume que esses universais operam normalmente na realidade (até mesmo como formas de adaptação e de defesa dos seres), mas que podem assumir contornos patológicos ou gerar situações patológicas (quando se tornam muito persistentes ou se aplicam a contextos inapropriados).

Para o autor, as expressões lingüísticas refletem esses universais da modelagem experiencial. Por exemplo, há pessoas que utilizam muitos operadores modais de possibilidade ou de necessidade. São expressões do tipo: 'é impossível que', 'não posso fazer tal coisa'; 'não é capaz de...' (de possibilidade) ou 'é necessário...'; 'temos de fazer' (de necessidade) etc. São expressões que indicam um limite ou uma impossibilidade, mas não dão informações precisas sobre como 
opera este limite. Na prática, denotam uma extrema rigidez e crenças arraigadas. Os operadores modais se enquadram na classe das omissões. Exemplos de generalizações são as expressões que se utilizam de quantificadores universais do tipo: 'nunca', 'todos', 'ninguém' etc., ou aquelas sem índice referencial como 'não quiseram me deixar falar'. As relações de causa-efeito são consideradas formas de distorção, pois neste caso comete-se, em geral, a inexatidão de atribuir uma única causa a um efeito, assim como as nominalizações que transformam algo dinâmico em um dado fixo, absoluto. A taxonomia geral é bem mais abrangente; o objetivo aqui é apenas dar alguns exemplos.

A idéia implícita é que as expressões lingüísticas configuram uma forma de linguagem superficial que não dá conta do contexto global das representações de base - que correspondem a um nível mais profundo da linguagem. Se eu digo 'João comprou um carro', trata-se de uma estrutura superficial; a estrutura profunda correspondente poderia ser: 'João o comprou de alguém, em tal dia, em tal lugar, um carro de tal marca por determinada quantia'. Assim, a estrutura profunda compreenderia os elementos lingüísticos que representam a experiência, não necessariamente todos, porque os universais de modelagem interviriam uma primeira vez entre a experiência e a estrutura profunda da linguagem, e uma segunda vez entre esta última e a estrutura superficial. Em uma situação patológica, uma eventual tarefa terapêutica consistiria em chegar aos níveis mais profundos, religando o paciente à experiência negada, distorcida ou generalizada, de modo a ampliar suas possibilidades. Pressupõe-se, no caso, que o uso sistemático de expressões classificáveis nos universais de modelagem limitam o modelo de mundo dos seres humanos.

Comunicadores afetos a escolas da psicologia comportamental (Bandler \& Grinder, 1981) apresentam um modelo de questionamento simples (modelo de precisão) que ajudaria a "aprofundar" a linguagem, a diminuir a ambigüidade virtual. Por exemplo:

- no caso da utilização de operadores modais, duas perguntas seriam pertinentes: ‘o que o impede de... ?' (quando a afirmação é: 'não posso fazer tal coisa'); 'o que aconteceria se não ocorresse $X$ ?' (no caso da afirmação: 'devo fazer tal coisa').

- no caso da utilização excessiva de quantificadores universais, do tipo 'ninguém me compreende', pode-se utilizar, em tom interrogativo, o quantificador universal: 'ninguém?' ou exagerar a afirmação acrescentando a ela outro quantificador universal ou inclusive o termo 'é verdade’?

- $\quad$ em relação a expressões sem índice referencial, como já citada, pode ser utilizada a interrogação: 'quem'?

- em relação à utilização de vínculos de causa-efeito do tipo: 'eu sairia de férias, mas não tenho carro', a conexão poderia ser questionada, virando a 
afirmação da seguinte forma: 'Ou seja, se você tivesse um carro, sairia de férias?’; a modificação da forma da afirmação permitiria verificar a existência do vínculo ou deixar aberta a possibilidade de uma réplica (outras formas específicas de enfraquecer vínculos deste tipo serão apresentadas mais adiante).

- quando da utilização de nominalizações, como por exemplo: 'eu tenho esperança', usar: 'o que você espera?', ou 'a dor me esmaga', usar: 'como especificamente ela te esmaga?' (as perguntas o quê? ou como? tencionariam transformar substantivos abstratos em dimensões de processo).

Considera-se, portanto, que a linguagem apresenta "zonas de sombras" que seria preciso iluminar através de um questionamento efetivo e oportuno. Isto corresponde à busca de uma "objetivização" da linguagem que facilite o entendimento dos predicados, que ajude à compreensão do que se formula, que permita um maior esclarecimento do que o outro diz. É a busca por um falar verdadeiro.

Mas considerando-se a criatividade e o exercício da influência, o uso deliberado da linguagem "com zonas de sombra", da linguagem vaga, de enunciados ad-hoc seria paradoxalmente aconselhável, por considerar-se que essa forma exige do ouvinte que ele ative a própria vivência interna, na medida em que, nas deliberações feitas, estão ausentes quase todas as informações específicas. Dito de outra forma, a linguagem vaga estimula a imaginação do ouvinte, contribui para desencadear um movimento interno no sentido da busca de respostas ou de expressões mais precisas e concretas. $\mathrm{O}$ uso de nominalizações ajudaria no exercício da criatividade e da expansão de possibilidades. Este falar vago teria, isso sim, d deslizar rapidamente para um tipo de falar verdadeiro, para resgatar o conteúdo preciso dos produtos da imaginação (Cudicio, 1992). O falar vago e outras formas, apontadas a seguir, correspondem à utilização invertida do metamodelo lingüístico, ao denominado modelo Milton, alusão ao americano Milton Erickson, talvez o maior psiquiatra hipnotista da época moderna.

A linguagem de modelo Milton comporta inúmeras possibilidades (Bandler \& Grinder;1981), como, por exemplo:

- A utilização principalmente de nominalizações, que se prestam a uma diversidade de conteúdos subjetivos, possibilitando despertar a criatividade do interlocutor.

- O uso de pressuposições do tipo 'não sei qual dos dois aparelhos vai comprar' (a suposição é a da compra), consideradas um dos mais poderosos padrões lingüísticos quando empregados por um comunicador que pressupõe aquilo que não quer que seja questionado. Um princípio geral é apresentar à pessoa muitas e muitas alternativas de escolha sendo que, apesar disso, todas elas pressupõem a resposta que você deseja. 
- O uso de vínculos de causa-efeito do tipo 'enquanto duvidamos, nossos concorrentes começam a ocupar pontos estratégicos’ (este é um vínculo propiciado pelo conectivo 'enquanto'). Nestes casos, o comunicador procura ligar algo que está ocorrendo com algo que ele quer que ocorra, convidando o ouvinte a responder como se uma das coisas fosse na realidade a 'causa' da outra. Estes vínculos se apóiam na tendência reconfortante que as pessoas têm de fazer associações, de atribuir uma causalidade tranqüila, acrítica a determinadas coisas (sobre tudo quando uma parte da sentença é um fato que ocorre na realidade). Uma interpretação possível da sentença anterior pode ser a de um chamamento para evitar a indefinição, a divisão, como causa possível da perda de posições.

- A possibilidade de ordens embutidas. Ao invés de dar abertamente as instruções, o comunicador embute diretivas dentro de uma estrutura mais ampla da sentença, que pode ser uma estória. Esta técnica pode ser reforçada pela "marcação análoga" que consiste em dar ênfase a determinadas partes da frase com a ajuda de comportamentos não-verbais (pausas, entonações, gestos, qualidade da voz etc.) para estimular a atenção consciente e inconsciente do ouvinte.

- A utilização de citações de outras pessoas para apresentar indiretamente mensagens, assim como de metáforas, inscrevem-se como outros recursos que ajudam a diminuir ou a quebrar resistências eventuais do ouvinte, que colaboram para a veiculação de conteúdos. Elaborar uma metáfora implica construir um texto que tenha uma estrutura isomórfica em relação à situação de base, mas cujo desenlace se modifica no sentido em que se pretende transitar.

Citamos apenas estas possibilidades no intuito de ilustrar como a técnica da comunicação hipnótica pode ser explorada no campo da persuasão. Podemos enriquecer esta narrativa citando algumas outras alternativas também muito úteis:

- O uso de ordens negativas em pessoas resistentes ou responsivas no sentido inverso daquele em que são instruídas. Exemplo: 'não quero que você tenha uma sensação de relaxamento e conforto'. Uma resposta de polaridade pode ser o efetivo relaxamento.

- Evitar, no caso de pessoas rígidas e contraditórias, a utilização exagerada do 'sim, mas ...' e dos contra-exemplos, pois isto pode contribuir para reforçar uma dada posição. Seria melhor seguir a corrente do ouvinte, exagerando ou enfatizando propositalmente a problemática ou a posição do mesmo, que neste caso, o próprio ouvinte poderá dar os contra-exemplos necessários à reformulação de uma dada posição que insista em manter. Reagirá assim com uma alternativa de polaridade. 
- Anunciar as conseqüências negativas de um não acordo caminha na direção daquela tendência natural - já citada - de fugir do desagradável, podendo abrir espaço para possibilidades de acordo.

- A modificação proposital do sistema de representação consciente do outro (implícita, por exemplo, nas técnicas de dissociação) criaria estados alterados de consciência, que são estados que se caracterizam por uma menor resistência à possibilidade de novos aprendizados, de uma mudança.

- A interrupção brusca (através de recursos vários) de padrões arraigados de comportamento do outro comportaria a mesma lógica anterior e é um dos recursos mais importantes dos processos de indução hipnótica. Interromper repentinamente uma "lenga-lenga" é uma interrupção de padrão que gera um estado alterado de consciência, de confusão, que pode ser explorado para efeitos de produção de novos significados.

Finalizaremos esta parte fazendo referência a alguns meios de influência citados por Cudicio (1992) cuja finalidade seria quebrantar ou questionar relações de causa-efeito implícitas nos enunciados do outro. Estas técnicas pretendem reorientar a discussão na direção de novas opções diante de uma afirmação peremptória que reflete o beco sem saída a que chegou um conflito. Serviriam, portanto, para manejar o conflito de maneira criativa e para influir sobre os outros (podendo levar à modificações de opiniões).

Vejamos um exemplo: 'Você sempre chega atrasado, isto demonstra sua falta de interesse no trabalho.' É um vínculo de causa-efeito e de igualdade. O critério implícito é a pontualidade, para o autor da afirmação.

Diante de afirmações desta natureza, o "cardápio da influência" contém genericamente três alternativas: deslocar, evitar ou dar contra-exemplos. Vejamos algumas possibilidades:

\section{Alargar ou comprimir o debate}

\section{Alargar}

A técnica consiste em alargar indo para níveis lógicos superiores. Se falássemos de um gato, poderíamos alargar passando para a categoria felino, depois mamífero, depois animal. Uma possível resposta seria: "Que significa 'chegar tarde', considerando que a empresa dispõe de toda a minha vida ativa futura?". 


\section{Comprimir}

Inversamente, agora podemos ir para níveis lógicos inferiores: 'só me atrasei exatamente 10 minutos'.

\section{Utilizar a hierarquia de critérios}

A técnica consiste em acrescentar critérios cada vez mais importantes: 'Para mim, o mais importante é a produtividade efetiva, não a demora’.

\section{Modificar o marco do debate}

Trata-se de modificar o marco, isto é o contexto. Podemos modificar seu tamanho, sua duração ou quaisquer elementos. Por exemplo: 'parece que você não soube o que aconteceu hoje'; ou: 'o que te faz saber que meu atraso tem a ver com um estado de ânimo?'.

\section{Os contra-exemplos}

É o 'sim, mas...', útil também no caso das pressuposições. Exemplos: 'Se você costumasse chegar tarde, isto significaria que você não se importa com o trabalho', ou 'Fulano de tal sempre chegava tarde, mas sua dedicação e a sua produção desmentiam críticas como a sua.'

\section{Refutar}

É possível refutar o comportamento exterior, o critério ou a causa-efeito.

- O comportamento: 'Você não percebe, mas, na verdade, eu me importo'.

- O critério: 'Então, o que conta para você é a hora? Em que me transformei aqui dentro? Meu rendimento não interessa?'

- A causa-efeito: 'se não eu chegasse tarde, você acreditaria que me importo com o trabalho?' 


\section{Reformular, redefinir}

Pode-se reformular a frase mas na forma de uma interrogação ou redefinila para verificar sua exatidão. Quando afirmamos algo de má-fé dificilmente conseguimos repetir pela segunda vez a afirmação com a mesma convicção. Exemplo: 'se entendi bem, o fato de chegar atrasado significa que não me importo com o trabalho?'

\section{A estratégia de realidade}

Este traço distintivo coloca a seguinte pergunta: Como sabe uma pessoa o que sabe, e de que elementos necessita para verificar sua experiência? Exemplo: 'Como você pode saber que não me importo com o nosso trabalho?'

\section{O objetivo}

Interrogamos sobre o objetivo da pessoa ou de sua afirmação. Exemplo: 'O que você ganha perguntando isto?'; 'O que você pretende fazer para solucionar o problema?'.

E assim por diante, trata-se de um conjunto de técnicas simples de influência que buscam desviar a atenção do problema ou o foco de concentração do outro, deslocar o nível de análise envolvido ou arrolar argumentos contrários a determinadas afirmações. Desta maneira, presume-se atingir uma situação de amenização de conflitos ou demover outros de suas posições.

Sobre um provável sentido manipulador destas técnicas, poderia-se afirmar que nenhuma técnica é neutra, dependendo de quem as utiliza. E que, assim como elas podem ser utilizadas para induzir posições nos outros, podem também ajudar a detectar esta intenção nos interlocutores e a desarmá-la. Podem ajudar, ainda, a modificar posições tidas como equívocas, negativas. Em relação, agora, ao falar vago, deve-se salientar que esta forma não pode ser absolutizada, pressupondo uma derivação permanente para o falar verdadeiro, e que, nesse caso, não se trata da transmissão de mensagens específicas, mas de generalizações que podem intensificar a geração de idéias novas e variadas, de utilidade para a negociação. Dito de outra maneira, nenhuma mensagem contrária ao ponto de vista do interlocutor é transferida; a resposta está no próprio ouvinte. O importante é resgatar que uma estratégia inteligente de combinação de falares deve estar subordinada à busca de um entendimento duradouro, que não signifique a negação absoluta de nenhuma da partes do jogo. 


\section{Considerações Finais}

Buscamos, aqui, apresentar a idéia de que a negociação é um processo de criatividade e de comunicação intensiva. A questão central é conseguir gerar a máxima quantidade de idéias ou opções capazes de ensejar acordos de alcance variado, para além da busca de uma única forma ou da fixação em um único tipo de resposta.

O modelo de negociação é altamente desestruturado, de difícil planejamento e controle. Depende das situações em jogo, dos tipos de negociador e de inúmeras variáveis subjetivas e objetivas. Mas um esforço pode ser feito no sentido de um planejamento mínimo, cujo objetivo seja o de chegar à negociação com alternativas.

Procuramos, no desenvolvimento da apresentação do modelo cooperativo, ajudar a instrumentalizar gerentes no exercício do mesmo, convictos de que, apesar da dinamicidade da negociação, o que significa assumir várias formas entrelaçadas e evolutivas, a possibilidade de um acordo duradouro, superior, insere-se na perspectiva do ganhar-ganhar.

Planejamento da negociação significa um mínimo de antevisão de possibilidades. Pode-se simulá-las mais facilmente utilizando um roteiro como o que apresentamos no Anexo, cujo único objetivo é gerar informação que pode ser útil, de acordo com cada caso real.

Terminamos aqui reafirmando a necessidade de um enfoque pragmático que combine argumentação e persuasão, esta última subordinada. Idealizamos, no entanto, um enfoque argumentativo, em que o livre e irrestrito exercício da comunicação crítica seja a tônica. Não deixa de ser uma boa causa.

\section{Referências Bibliográficas}

BANDLER, R. \& GRINDER, J. Atravessando. Passagens em Psicoterapia. São Paulo: Summus, 1981. (anexo final sobre o modelo Milton).

CHALVIN, D. LEntreprise Négociatrice. Paris: Dunod, 1997.

CHOMSKY, N. Aspects of the Theory of Sintax. Cambridge: MIT Press, 1965.

CUDÍCIO, C. Cómo Compreender la P.N.L. Introducción a la Programación Neurolinguística. Argentina: Granica, 1992. (Série Alternativa Management)

FISHER, R. \& URY, W. Como Chegar ao Sim. A Negociação de Acordos sem Concessões. Rio de Janeiro: Imago, 1982. 
FISHER, R. \& BROWN, S. Como Chegar a um Acordo. A construção do relacionamento que leva ao sim. Porto Alegre: Imago, 1990.

FISHER,R. \& ERTEL, D. Estratégias de Negociação. Um Guia Passo a Passo para Chegar ao Sucesso em Qualquer Situação. Rio de Janeiro: Ediouro, 1997.

KLUCZNY, J. NLP. Practitioner Training Manual. Seminário NLP in Rio, jan. 1993. (Mimeo.)

MATUS, C. PES. Guia de Análisis Teórico. Fundación Altadir. Venezuela, 1994 (Mimeo.)

MINTZBERG, H. Structure et Dinamique des Organizations. Paris: Les Éditions d'Organization, 1982.

RIVERA, F. J. U. Por um Contraponto Teórico-metodológico entre o Planejamento Estratégico-Situacional (PES) e o Controle da Qualidade Total (T.Q.C.) na Saúde Pública.. Rio de Janeiro, ENSP/Fiocruz, 1995. (Mimeo.)

URY, W. L.Supere o Não. Negociando com Pessoas Dificieis. São Paulo: Best-Seller, 1991.

ZAJDSZNAJDER, L. Teoria e Prática da Negociação - Política de Negociação. Rio de Janeiro: José Olympio, 1988.

ZAPIOLA, C. La Negociación. Un Enfoque Integral con Especificas Referencias a la Negociación Laboral. Bogotá: Ed. Macchi, 1992. 


\title{
(INTER)SUBJETIVIDADE, APRENDIZAGEM ORGANIZACIONAL E MUDANÇA: algumas ferramentas lúdico-pragmáticas
}

Francisco Javier Uribe Rivera

\begin{abstract}
Pretendemos, aqui, estabelecer correlações entre gestão e subjetividade e o fazemos pelo lado da aprendizagem. A determinação de correlacionar nos permite apresentar em grandes linhas entendimentos teóricos e proposições instrumentais típicos do paradigma gerencial da organização que aprende, que corresponde a uma expressiva metáfora organizacional.

Acrescentamos aqui dados sobre a visão mais atualizada de liderança daquele paradigma, entendendo que a liderança é uma categoria básica da gestão e dos processos de mudança organizacional que acentua o dilema entre o caráter subjetivo (ou individual) e o caráter social da condução desses processos.

Nosso objetivo não é o de negar a subjetividade inerente ao campo administrativo, mas de questionar o seu uso analítico como categoria ou instância separada dos processos de interação comunicativa que definem, do nosso ponto de vista, a essência da gestão administrativa.

Apresentamos, ainda, algumas ferramentas utilizadas pela organização que aprende e que se constituem em instrumentos de reflexão, de diálogo e de negociação, de questionamento dos fundamentos cognitivos e emocionais do perceber e do agir mesmos (em geral ocultos).

Apresentamos, finalmente, estratégias referentes a como encaminhar processos de mudança organizacional, fruto de desenvolvimentos recentes dos autores mais destacados da learning organization.
\end{abstract}

\section{Aprendizagem, Subjetividade e Planejamento}

A subjetividade na gestão é um tema que está na ordem do dia em função da relativa crise da gestão procedimental e da emergência de uma nova visão que 
destaca a importância da cultura (na formulação dos objetivos organizacionais), da liderança comunicativa e da aprendizagem organizacional. A organização passa a ser concebida como uma sociedade que aprende a aprender.

A aprendizagem, para os teóricos da learning organization, deve ser vista como um processo contínuo com as seguintes etapas: aprender a perceber ou a reinterpretar uma situação, aprender como aplicar esta percepção para a formulação de uma política e especificação de uma ação, aprender como implementar estas políticas e ações pretendidas, e aprender como manter estes três últimos itens ativos, vivos, e abertos a constante revisão (site www.zumble.com.br, seção aprendizagem e desempenho).

Esta definição é importante porque se aproxima significativamente do escopo do planejamento, área de trabalho dentro da qual desenvolvemos nossa reflexão desde uma perspectiva situacional e comunicativa. A coincidência que se coloca entre nosso enfoque de base e o da organização que aprende está relacionada à percepção da realidade como um processo mediatizado pelo nosso próprio recorte situacional, privilegiando aqui o ângulo de nossa cultura, de nossos valores e crenças. Esta percepção interessada da realidade, que extraímos de Matus (1993), confunde-se com a visão da realidade como processo que supõe o filtro de nossos próprios modelos mentais, termo caro aos teóricos da organização que aprende. Os modelos mentais são definidos por Senge et al. (1995) como pressupostos profundamente enraizados, generalizações ou imagens que temos, que influenciam o modo como percebemos o mundo e agimos sobre ele.

Maturana (1998) defende que a racionalidade é um plano constituído de premissas que aceitamos porque nos agradam (idéia que reforça o predomínio das emoções sobre o racional) e que o caminho que leva à percepção é o da objetividade entre parênteses, que significa que o ato de conhecer depende do observador e se estrutura enquanto um convite ao outro a um tipo de diálogo sobre a validade das coerências operacionais do conhecer mesmo. Esta posição reforça a idéia matusiana de que existem várias formas de explicar uma mesma realidade, de acordo com a perspectiva específica do observador.

Mitroff (1999) é outro autor que assinala haver uma profunda relação entre a forma de analisar problemas e determinados tipos psicológicos derivados de uma interpretação do ser humano baseada em Jung. De acordo com esses tipos, uma mesma realidade poderá ser apreendida de maneira mais sistemática ou de uma maneira fragmentada e detalhista, mais voltada para tecnicismos ou para aspectos humanos e sociais. A particular subjetividade dos indivíduos contribuirá para a geração de explicações diferenciadas e para soluções várias que não comportariam o critério da solução "certa". Todas poderão ser encaradas como certas. Nesta medida, o ato de analisar problemas implica a necessidade de in- 
corporar a maior parte dos envolvidos nos mesmos e de experimentar vários enunciados e explicações. Nesta linha da complexidade da análise de problemas, Mitroff formula, ainda, a idéia de que, atualmente, o paradoxo faz parte essencial da administração, pois a realidade reconhece inúmeras situações "onde mais pode levar a menos", como por exemplo, a corrida armamentista. A capacidade de lidar com paradoxos seria mais um atributo fundamental da arte da liderança. Chama a atenção, neste autor, a mesma preocupação manifestada por Maturana acerca da influência das emoções e da espiritualidade na possibilidade de lidar com os fenômenos administrativos e da cognição em geral.

Não existindo, portanto, um conhecimento absoluto independente do observador, a primeira etapa da aprendizagem (interpretativa) se constitui como possibilidade de interação lingüística voltada para o questionamento dos modelos mentais que presidem a percepção dos vários observadores. Neste particular, referimo-nos à aprendizagem como processo coletivo ou organizacional, que corresponde segundo Kim (1996) ao processo de transferência dos conteúdos da aprendizagem individual que redunda em um saber consensual, cristalizado como memória social tácita ou cultura. É este processo de socialização do saber que fundamenta, habermasianamente, a validade relativa a contextos concretos do saber como racionalidade.

É extremamente interessante perceber que, entre os teóricos da learning organization, o planejamento é um processo de aprendizagem que permite o afloramento e o questionamento dos modelos mentais dos agentes tendo em vista a possibilidade de uma visão compartilhada. Arie P. de Geus (1997) sustenta, assim, que o verdadeiro propósito do planejamento eficaz não é fazer planos, mas mudar o microcosmo, os modelos mentais que os tomadores de decisões carregam em suas mentes.

Nesta perspectiva, a idéia burocrática de gabinetes de planejamento cede o lugar a uma concepção dinâmica de laboratórios de aprendizagem, de oficinas de planejamento onde o o processo interessa mais do que o resultado.

Para Kim (1996), a aprendizagem supõe um ciclo que se inicia com a captação de novos dados, referentes a reações do ambiente a uma ação implementada, que prossegue com a consideração de lembranças de experiências passadas no processo de atribuir significado ou de concluir algo sobre esse novo fragmento de informação (aprendizagem individual) e que se encerra com o armazenamento desses significados sob a forma de modelos mentais individuais. Este autor destaca que há dois modos de aprendizagem: o operacional, relativo a como implementar processos de trabalho e rotinas (habilidades) e o conceitual, relativo ao porquê destes processos ou habilidades (conhecimento). Este último tipo seria o responsável pela introdução de novas realidades ao desafiar a natureza mesma dos processos existentes. A aprendizagem efetiva exigiria a presença de ambas as formas. 
O mesmo autor assinala a existência de ciclos incompletos de aprendizagem. A aprendizagem situacional corresponderia a uma situação em que mudanças no plano da percepção e da ação aconteceriam em contextos de muita especificidade, sem levar a modificações nos modelos mentais individuais (administração de crises). A aprendizagem fragmentada, que levaria à perda de conhecimento, corresponderia a um corte entre a aprendizagem individual e coletiva. Já a aprendizagem oportunista corresponderia a um tipo de orientação da ação que rompe seu vínculo com a memória organizacional.

A efetividade da aprendizagem dependeria de ir além da aprendizagem situacional e fragmentada e de se utilizar do aprendizado oportunista. Corrigir a aprendizagem situacional implicaria transferir as novas percepções específicas para mapas mais genéricos da realidade, situar esse novos dados em contextos de maior complexidade, caracterizados por um elenco mais abrangente e dinâmico de relações de causalidade (para o autor, os arquétipos sistêmicos de Senge podem ser de utilidade aqui). A superação do aprendizado fragmentado chama a atenção para a necessidade de laboratórios de aprendizagem onde se pratique, o diálogo, a simulação coletiva, a argumentação e a indagação. A utilização do aprendizado oportunista corresponderia a um apelo no sentido do planejamento através de cenários, entendido como uma possibilidade de alargamento de horizontes capaz de levar a uma superação relativa do determinismo da cultura prévia.

Dada a nossa formação cultural, pensamos que a aplicação criativa, flexível e simplificada do raciocínio do planejamento estratégico-situacional supre, em boa medida, as exigências implícitas no pensamento sistêmico de Jay Forrester e Peter Senge. Referimo-nos, como anunciamos, à idéia de uma explicação causal totalizadora (para além da compartimentalização do saber) e rigorosa, no sentido de apontar causas subjacentes e essenciais. Ora, também vemos na operacionalidade das oficinas de trabalho de planejamento processos ou laboratórios de aprendizagem em que a busca do consenso a partir das diferenças situacionais contribui para a superação do aprendizado fragmentado e para a geração de cultura ou de uma comunidade de idéias.

Pensamos, por outro lado, que o planejamento situacional matusiano deveria enfatizar uma importante opinião de Kim (1996), segundo a qual o modelo administrativo predominante de problema-solução pode levar a ofuscar a pertinência ou não do(s) problema(s) escolhido(s). Para este último, muito mais importante relativamente do que a própria problematização é a capacidade de articulação do problema, que corresponde à definição do mesmo como dependente de nossas premissas mais profundas ou modelos mentais. Assim, decompor um problema e descobrir um meio de rearticulá-lo pode prover melhores condições do que somente tentar redobrar esforços para solucioná-lo na forma em que se apresenta inicialmente. 
Uma das idéias que mais nos impressiona em teóricos da learning organization diz respeito à relativa fragilidade da experiência para prover elementos para aprendizagem. Isto tem a ver, como apontamos, com o conceito de complexidade dinâmica, que aprofundaremos mais adiante. Aqui podemos colocar de maneira simples que atualmente é muito difícil prever com algum grau de precisão as conseqüências de atos que praticamos hoje a partir de determinadas informações obtidas sobre problemas. Estas conseqüências podem ser remotas ou distantes no tempo e no espaço, devido à intermediação em um determinado ciclo informação-ação-resultados de muitos outros ciclos e agentes. Dada esta difícil previsibilidade dos fenômenos a partir da experiência passada, surge a necessidade de aprender do futuro, entendendo a técnica de cenários como um diálogo-narrativa do futuro que no fundo seria um diálogo sobre os modelos mentais ou os filtros que aplicamos na percepção do futuro (técnica de cenários enquanto "lembrança do futuro"). Esse diálogo pode ajudar a realinhar a visão. Não interessa tanto a probabilidade de uma dada narrativa. Ela poderá se constituir, como aprendemos de um aluno de um curso nosso, em uma espécie de "profecia autorealizável", pela força da convicção representada pelo compartilhamento.

Gostaríamos de terminar esta parte com considerações sobre a aprendizagem como fenômeno individual que depende da socialização e de uma interação mais ampla com o meio, bem como sobre a aprendizagem como mudança orientada para a ação.

Maturana (1998) define a aprendizagem como um processo contínuo de mudanças de comportamento induzido pela necessidade de um acoplamento estrutural entre indivíduo e meio. A aprendizagem corresponde às mudanças ocorridas ao longo da vida em função de uma rede de interações com os outros e o meio, que se orienta para a adaptação diante das demandas recorrentes. Neste processo histórico, tanto se dá a (re)produção do indivíduo quanto a do meio. A aprendizagem, como a cognição, está orientada para o fazer. Aprender é mudar para fazer. Aprender é fazer. Neste contexto interpretativo, o nosso discurso sobre planejamento como aprendizagem remete à contínua necessidade de percepção de situações para a delimitação de ações. Como afirma Matus (1993), o fenômeno do planejamento é a mediação entre o conhecimento e a ação.

Piaget (apud Freitag, 1985), ao se referir ao desenvolvimento ontogênico do indivíduo, sustenta a idéia de que essa evolução estaria caracterizada pelo fenômeno da "descentração". A "descentração" constitui um processo de socialização que levaria a criança do monólogo (autista) ao diálogo, da ação e interação às operações hipotético-dedutivas, da pré-moralidade à autonomia moral. Neste percurso, a criança faz um aprendizado em que passa distinguir o mundo externo do interno e subseqüentemente o mundo externo dos objetos do mundo social. A "descentração" reuniria dois movimentos concomitantes e complementares: o envolvi- 
mento crescente do indivíduo pelo grupo (socialização), traduzido em seu pensamento e sua linguagem socializada, e o distanciamento consciente do indivíduo com relação a seu grupo e às normas que regulamentam sua interação, traduzido em uma crescente individualização e autonomização (conscientização).

A aprendizagem, embora basicamente individual, pressupõe, assim, uma relação permanente para fora, uma intersubjetividade e uma relação com o objeto em geral, em situações de práxis. Dito de outro modo, as capacidades de cognição e de socialização que tipificam o mundo subjetivo ou da personalidade constituem estruturas que se alimentam principalmente da dinâmica das estruturas do mundo social, das normas e dos fatos sociais (Habermas, 1987).

A subjetividade, então, é indissociável da intersubjetividade. O dilema que pesa sobre a aprendizagem é a possibilidade de superação do aprendizado fragmentado e situacional pela ingerência do diálogo ou da argumentação crítica. Se a aprendizagem é primariamente individual, embora ocorra em contextos de acoplamento, a possibilidade de que ela venha a reverter em usos sistêmicos depende de sua transformação em concepções de mundo ou em sistemas de idéias dotados de legitimidade.

\section{As Correntes da Learning Organization}

Atualmente, identificam-se três correntes (Boyett, 1999):

- Uma abordagem que considera que o principal obstáculo ao aprendizado individual e organizacional corresponderia à dificuldade de explicitar e questionar ("desafiar") livremente os modelos mentais dos participantes de uma organização. Este enfoque estaria representado pelo trabalho dos professores Christopher Argyris (especialista em educação e comportamento organizacional de Harvard) e Donald Schön, do Massachutess Institute of Techology (MIT).

- Uma abordagem que se concentra nos problemas de aprendizado que ocorrem quando os modelos mentais do tipo 'se-então' estão incorretos por duas diferentes razões: primeiramente, porque atribuem um relacionamento causal a alguns eventos e esse relacionamento não existe e, em segundo lugar, porque não reconhecem esse relacionamento causal quando ele existe. Esta abordagem está mais associada aos trabalhos de Peter Senge, Jay W. Forrester e do Center for Organizational Learning, do MIT.

- Uma abordagem mais cultural, representada pelo trabalho do professor do MIT Edgard Schein, que explora as relações entre as possibilidades de aprendizagem organizacional e as condições necessárias do ponto de vista da cultura organizacional. 
O primeiro enfoque chama a atenção para a necessidade de desacelerar nossos processos mentais de modo a nos tornar conscientes de nossos modelos mentais, através da reflexão, e adquirir habilidades de indagação e de argumentação que colaborem para o questionamento de nossos modelos e dos modelos dos outros. Argyris (1997) sustenta que as pessoas têm a predisposição a tirar conclusões precipitadas acerca da conduta dos demais (a "subir a escada de inferência"), devido a uma leitura parcial dos dados da experiência e a uma interpretação enviesada desses dados em função de preconceitos ou crenças culturais arraigadas. Por outro lado, o autor assinala que o clima organizacional se caracteriza em geral pela presença de rotinas defensivas, que fazem parte de um modelo denominado da "incompetência qualificada"(Argyris, 1977) ou modelo 1, que apresenta alguns traços como:

- Tentar gerenciar o ambiente de trabalho, visando ao maior controle possível dos fatores que o afetam.

- Aprovar e elogiar os outros. Dizer sempre o que você acredita que fará com que as outras pessoas se sintam bem em relação a si mesmas. Não ferir seus sentimentos. Dizer sempre o quanto se preocupa com elas e, se possível, concordar quando dizem que outras pessoas agiram inadequadamente.

- Nunca confrontar as razões ou ações dos outros com as suas.

- Defender sua posição para vencer. Manter sua posição sempre. Temer reconhecer suas fraquezas (debilidade imprópria de uma liderança).

- Nunca dizer aos outros tudo o que você pensa ou sente.

- Manter seus princípios, valores e crenças.

Este autor sugere uma série de técnicas que visam a trazer à tona e questionar o não dito presente em situações de interação mal sucedida, e inserir em situações de diálogo um espírito de indagação, de autocolocação autêntica e de crítica, que possibilite aumentar a capacidade de avaliação do comportamento defensivo e das conseqüências negativas não reconhecidas. Essas técnicas ajudariam a promover uma evolução para o chamado Modelo 2, definido, por Amatucci (1999), como um modelo caracterizado:

- pela busca e elaboração de informação válida, testada, consagrada discursivamente;

- pela exploração desse material na fundamentação do processo de tomada de decisão, livre e informada;

- pelo comprometimento interno com a decisão e monitoramento constante da implementação.

Se o modelo 1 é um modelo de comunicação manipuladora, em que predominam a persuasão e a indução estratégica, marcado por um pretenso racionalis- 
mo e pela tentativa de uma proteção unilateral do outro, o modelo 2 é um modelo de raciocínio produtivo, em que não se trata de "salvar a cara" de ninguém, mas de promover um diálogo crítico que não abafe sentimentos e emoções, que persiga a verdade e a autenticidade, a proteção bilateral de si próprio e do outro (reciprocidade).

É notória a filiação da ciência da ação de Argyris, enfatizada por Amatucci, a uma Teoria Crítica da Sociedade, mais especificamente ao modelo da Teoria do Agir Comunicativo de Habermas (1987). Desta maneira, surge uma conexão interessante entre uma metateoria filosófica e uma escola de educação e comportamento organizacional que solidifica a metáfora das organizações que aprendem.

Senge é o autor que exerce a liderança mais forte dentro do campo da “organização que aprende”. Em obra de 1995 (Senge et al., 1995), ele condensa a contribuição de vários dos membros do movimento, ensejando aos leitores um acúmulo de técnicas pragmáticas ligadas à possibilidade do aprendizado. Este autor faz aportes específicos em duas áreas importantes de análise: a dinâmica de sistemas e a teoria da liderança.

Para Senge (et al., 1995), a dificuldade de reconhecimento dos relacionamentos de causalidade sistêmica se deve ao fato de que nossos modelos mentais traçam o quadro de um mundo unidirecional no qual um problema leva a uma ação que leva a uma solução. Nossos modelos mentais implicam uma estrutura simples como esta: informação sobre o problema $\rightarrow$ ação $\rightarrow$ resultado. No entanto, vivemos em um ambiente circular contínuo, onde cada ação baseia-se nas condições atuais. Essas ações afetam as condições e as condições alteradas tornam-se a base de futuras ações. O processo não tem começo nem fim. As pessoas são interconectadas. Muitos desses loops são interligados. Através de longas cadeias de ações em cascatas cada pessoa reage continuamente ao eco de suas ações anteriores, bem como das ações dos outros. O mundo é uma longa mola de causalidade onde causa e efeito giram continuamente. Esta mola pode girar de forma ordenada ou esticar-se fortuitamente, com longos lapsos de tempo entre ação e resultado. Nos sistemas compostos de feedbacks em interação e longos intervalos de tempo, as causas de um sintoma observado podem ser provenientes de uma parte inteiramente diferente do sistema, e muito afastada no tempo. Para confundir ainda mais as coisas, tais sistemas apresentam indícios que fomos condicionados a esperar. Mas, em geral, esses sintomas coincidentes ou causas aparentes surgem de uma causa distante. As pessoas são assim atraídas por ações que não são relevantes para solucionar o problema em questão.

Os autores propõem um treinamento no pensamento sistêmico, capaz de ajudar a melhorar as percepções desses relacionamentos de causalidade. Os principais elementos desse treinamento seriam: 
- A modelagem dinâmica de sistemas, que consiste em criar sistemas ou modelos no computador, simular seu comportamento, explorar como os modelos reagem ás mudanças na estrutura e nas políticas e comparar o comportamento do modelo com os sistemas reais que estão sendo apresentados. A modelagem de sistemas é uma atividade participativa na qual se aprende por tentativa e erro e pela prática. É o aprendizado pela surpresa dos erros cometidos.

- O uso dos chamados "arquétipos sistêmicos" (anexo a este capítulo), termo cunhado por Senge para denotar certas regularidades ou padrões de comportamento sistêmicos que se verificam continuamente nas situações de negócios. O reconhecimento do tipo particular de arquétipo correspondente a determinada situação problemática, assim como o exercício de uma estratégia de questionamento adequada a esse padrão de conduta, poderiam melhorar o raciocínio sistêmico e prover eventuais alternativas de ação.

- $\mathrm{O}$ uso de jogos de negócios,que consistem em verdadeiros simuladores de vôo, onde os participantes tomam decisões e avaliam os resultados em situações que não oferecem risco e que comprimem as dimensões de tempo e espaço. Estes jogos ajudariam a valorizar a interconexão dos eventos, a testar modelos mentais e a perceber o comportamento dinâmico de sistemas.

Temos certas resistências (Rivera, 2000b) à adoção de padrões interpretativos que não correspondem a nossos referenciais culturais. O desconhecimento dos elementos do pensamento sistêmico segundo a matriz de Forrester pode explicar esta reticência. Um certo incômodo nos gera a idéia de uns poucos arquétipos capazes de conter a diversidade de situações problemáticas vividas. Essa idéia nos sugere um certo reducionismo. No entanto, aderimos às idéias de fundo contidas na análise de Senge, que consistiriam, na nossa leitura, na possibilidade de:

- Desenvolver explicações complexas da realidade, capazes de apontar para as causas essenciais dos fenômenos e para a relação dinâmica das causas em geral. O modelo de uma explicação situacional ao estilo matusiano, de natureza auto-referencial, policêntrica, totalizadora e rigorosa, pode suprir a necessidade de um enfoque de causalidade como o apregoado por Senge.

- Estabelecer práticas de simulação que exercitem o raciocínio do tipo 'seentão'. Neste caso, referimo-nos ao planejamento estratégico de cenários, que nos permite simular a construção de situações futuras como conseqüência da interconexão do comportamento de várias variáveis-chave e da dinâmica dos atores sociais que as controlam, e que nos ajuda a pensar o que fazer em situações alternativas de futuro. Este raciocínio condicional seria um elemento do aprendizado organizacional de extrema importância, pois nos ajudaria a desenvolver a capacidade de mudar em função da 
circunstância real futura que pretendemos simular ex-ante com o nosso modelo. Nesta perspectiva, o confronto com várias possibilidades de futuro exerceria uma tensão contrária à rigidez de posições. Dado seu caráter redutor de variedade, preso ao essencial ou motriz, o planejamento de cenários seria também uma ferramenta auxiliar poderosa no desenvolvimento de um tipo de pensar voltado para a complexidade dinâmica, que definimos como uma narrativa que relativiza a extensividade do detalhe e que se prende ao movimento evolutivo de variáveis, tendências e relacionamentos realmente marcantes. Por fim, pensar o cenário futuro nos permitiria criar uma perspectiva oposta ao determinismo de nossa cultura, ao nos obrigar a pensar em novas possibilidades não claramente antevistas em função de nossa tradição.

- Estabelecer dinâmicas dialógicas que ajudem a discernir e a questionar os modelos de pensamento que subjazem às várias explicações possíveis de uma realidade. A radicalização da idéia de uma explicação situacional, que acentue o policentrismo e a necessidade de desvendar as premissas e os interesses valorativos que condicionam as leituras diferenciadas, insere-se nessa perspectiva.

Schein (2001) é o terceiro autor do movimento citado como formulador do enfoque cultural. A questão central que ele coloca é que tipo de cultura seria necessária à aprendizagem e como criá-la. A cultura necessária ao aprendizado apresentaria algumas características:

- Equilibra os interesse de todos os envolvidos: nenhum grupo domina o pensamento da gerência, pois é sabido que qualquer um desses grupos (clientes, funcionários, fornecedores, entre outros) pode atrapalhar e destruir a organização.

- Concentra-se nas pessoas, não nos sistemas: acredita-se na capacidade das pessoas de aprender, bem como de valorizar o aprendizado e a mudança.

- Faz as pessoas acreditarem na possibilidade de mudarem seu ambiente:o autor se coloca a seguinte questão: se acreditarmos que o mundo ao nosso redor não pode ser modificado, de que adianta aprender a aprender? Relaxe e não intervenha sobre algo predestinado.

- Encontra tempo para o aprendizado: um certo tempo de "folga"é desejável para ser usado para o aprendizado. Como diz o autor, ser enxuto e mau não é uma boa receita para o aprendizado organizacional.

- Adota uma abordagem holística dos problemas: estes apresentam dimensões múltiplas interconectadas e mecanismos de causalidade complexos.

- Estimula a comunicação aberta: há o compromisso com uma comunicação total e com a verdade. Desenvolveu-se um vocabulário comum que permite a comunicação. 
- Acredita no trabalho em equipe: a competição individualista não é vista como a resposta para todos os problemas.

- Tem líderes acessíveis, que reconhecem sua vulnerabilidade e incerteza e se colocam como professores e agentes de mudanças e não como carismáticos responsáveis pela decisão.

Schein (2001) reconhece que a cultura que predomina nas organizações é o contrário e que, em geral, pelas induções dessa cultura e de um modelo cético da natureza humana, não haveria espaço suficiente para o livre desenvolvimento do aprendizado coletivo. $\mathrm{O}$ autor sugere a necessidade da criação de "portos psicologicamente seguros" para o aprendizado ou de sistemas paralelos (dentro ou fora da organização) onde as pessoas teriam oportunidades de treinamento e prática, apoio e estímulo para superar o medo e a vergonha de cometer erros, treinamento e recompensas pelos esforços na direção certa, e normas que recompensem a inovação e a experimentação. Schein desiste do núcleo da organização como possibilidade de um ambiente seguro que opere como berço do aprendizado para a mudança e defende que esse sistema paralelo deveria ser criado bem no topo da organização, tendo o executivo como o principal aluno e sendo representado por um grupo em torno dele.

Observa-se uma importante contradição entre Schein e Senge, na medida em que este último considera um mito a ser combatido a idéia de que toda mudança importante vem de cima e sustenta uma visão ecológica da liderança, que subentende a necessidade de encarar toda a organização como a possibilidade de um ambiente seguro para o exercício da aprendizagem para a transformação. De qualquer maneira, subsiste a dúvida: como criar um ambiente seguro para a aprendizagem rompendo com o condicionamento de uma cultura impositiva sem apelar para induções externas?

Ocorre-nos aqui que: buscar formas de distanciar-se da cultura, ao olhá-la de fora (através de uma mudança ambiental e do diálogo interdisciplinar); intensificar os processos comunicativos voltados para o processamento de aspectos disfuncionais da cultura para o encaminhamento pragmático de problemas reais; assim como, a afirmação das diferenças representadas pelos aspectos individuais ou subjetivos ofuscados pela noção de cultura, podem representar pistas gerais para responder positivamente à questão anterior. Lembramos também da importância do planejamento a partir de cenários como forma de distanciamento da tradição e da experiência acumulada. 


\section{Liderança Individual ou Coletiva?}

Em capítulo anterior, discorremos sobre as habilidades básicas e as formas de desenvolvimento da liderança, segundo Senge. Chamamos a atenção para a capacidade da liderança de se constituir como processo de construção interativa da visão, sem anular os pontos de vista pessoais. A liderança, dentro desse entendimento, deveria saber administrar a diversidade dentro de uma mesma perspectiva e lidar criativamente com as antinomias e paradoxos. Destacamos, também, que o papel educativo da liderança consistiria em propiciar um ambiente de discernimento e de análise crítica dos modelos mentais individuais e sociais dos participantes de uma organização. Esta capacidade de possibilitar um mergulho nas estruturas interiores, profundas, das pessoas organizacionais é uma forma de resgate da importância do subjetivo nos processos administrativos.

No livro A Dança da Mudanças (1999), Senge desenvolve a versão mais atualizada de sua concepção de liderança. A partir da metáfora do jardim, o autor se contrapõe à imagem da liderança-herói. A liderança "jardineiro" não é aquele tipo que, prostrado sobre as plantas, implora: 'Cresçam, cresçam com afinco'. Esta liderança, ao contrário, reconhece que o crescimento das plantas depende de seu potencial e se decide a acompanhar seu ciclo natural, preocupando-se com as condições que reforçam e que limitam seu crescimento (água, solo, nutrientes, sol, outras árvores...). Por detrás desta imagem está a idéia de que as organizações devem ser vistas como sistemas biológicos e não como máquinas. No caso de uma concepção maquinal da organização, quando surge um problema, este é assimilado à condição de uma peça defeituosa que deve ser trocada. Na concepção biológica organizacional, lidamos com gente, com pessoas, que, assim como as plantas, não podem ser tratadas como peças de uma engrenagem. No caso do jardim, uma planta não morre para ser substituída por outra, simplesmente.O que acontece é que uma nova vai crescendo e acaba por tomar o lugar da velha. O mesmo ocorre com o comportamento. Se um comportamento novo é mais eficaz do que o antigo, então acaba conquistando espaço. Desta maneira, o líder-jardineiro seria aquele que tenta atuar sobre as condições limitadoras e promotoras do desenvolvimento potencial das pessoas organizacionais, especialmente sobre as condições básicas para uma aprendizagem coletiva solidária. Seriam estas condições de aprendizado, fatores propulsores ou realizadores do potencial de crescimento das pessoas, potencial esse que poderia ser tolhido em contextos impositivos e objetivantes.

A liderança, para Senge, não seria um fator individual. Ou apenas individual. Na sua visão ecológica de liderança, esta corresponde a uma capacidade coletiva para moldar as mudanças. $\mathrm{Na}$ organização, haveria vários líderes, em vários níveis, não necessariamente executivos. Destacam-se dentre eles os 'que portam 
a semente', aqueles que têm a capacidade de estabelecer redes mais ou menos informais de comunicação, de impulsionar, em todos os níveis, em relações de transversalidade, a possibilidade da transferência de habilidades e de conhecimentos. Estes líderes retirariam seu potencial da capacidade de estabelecer interconexões entre inovadores.

Para o autor, os grandes problemas que a mudança enfrenta são de tipo gerencial. Referem-se à incapacidade de gerar uma dinâmica de negociação de uma visão compartilhada, à dificuldade de trazer a tona temas "indiscutíveis" mediante o desenvolvimento de habilidades de reflexão e indagação, à tendência de evitar o enfrentamento das causas mais complexas dos problemas em prol de um tratamento sintomático, a um tipo de conduta defensiva que escamoteia medidas que podem afetar interesses etc.

Estas restrições, típicas da despreocupação dos dirigentes com a aprendizagem coletiva, podem ser compensadas através de estratégias de aprendizagem. Mas isto não é suficiente. A mudança exigiria uma maior concentração sobre os aspectos limitadores do crescimento, entendendo mudança não como troca ou substituição, ou produção de algo absolutamente novo, mas como crescimento (como evolução do novo a partir do antigo). A referência de Senge a Maturana: "a história é a transformação para a conservação", ou, dito de outra forma: "cada movimento está sendo inibido à medida que ocorre", corresponde ao reconhecimento de tendências naturais de compensação ou de limitação do crescimento, que deveriam ser o alvo privilegiado de uma reflexão estratégica sobre como agir para enfraquecer ou atenuar essas tendências e para adiar os momentos de inflexão compensadora. Toda esta reflexão aponta para a necessidade de pensar não em termos de impor mudanças, mas de cultivar mudanças.

Esta perspectiva não pretende afirmar que a liderança não seja individual.Trata, isso sim, das relações entre capacidades individuais e sociais.Tenciona reforçar a idéia de que líder é quem fomenta os processos de aprendizagem que podem gerar uma liderança disseminada, de que o desenvolvimento da liderança como instância individual depende de interações típicas do fenômeno social da aprendizagem.

Como vimos anteriormente, Motta (1991) formula que a essência da liderança consiste de capacidades de domínio do contexto (capacidades de análise estratégica do ambiente e dos problemas organizacionais, de intuição do futuro e de formulação da visão), capacidades de manejo intersubjetivo (comunicação e negociação) e individuais (como o bom conhecimento de si, a capacidade de socialização e a autenticidade). Reforçando a dimensão subjetiva, o autor se detém na importância do ilógico e da intuição na gestão administrativa, que explica o caráter às vezes pouco coerente e racional da tomada de decisão. Motta acrescenta que a intuição mistura elementos de racionalidade formal e informal e que 
esta se apóia fortemente na experiência acumulada pela liderança. Este destaque dado à dimensão subjetiva não-formal ou racional da liderança opera aqui como um argumento importante para não omitir sua natureza individual.

Em Bennis, também já explorado, encontramos, por fim, idéias importantes sobre a liderança como um fenômeno voltado prioritariamente para a mobilização das pessoas (e não necessariamente para a indução da motivação), para a reflexão futurista da grande visão em detrimento do detalhe operacional e para o desenvolvimento da inovação (Rivera, 2000a). Diferentemente da lógica do controle inerente à gestão tecno-burocrática clássica, o fenômeno da liderança atuaria como o exercício do poder para o desenvolvimento de dinâmicas de equipe e de interação disciplinar que favoreceriam a inovação e a mudança. A promoção da liderança dependeria muito de um tipo de aprendizado caracterizado pelo trânsito cultural entre disciplinas diferenciadas e informações aparentemente distantes. Esta linha de pensamento reforça, portanto, a idéia da liderança como processo de aprendizagem e como instância de mobilização das capacidades individuais e intersubjetivas da organização.

\section{Considerações Intermediárias a Título de Recapitulação}

O nexo que estabelecemos entre subjetividade e gestão corresponde ao entendimento da organização como sociedade que aprende e do planejamento como comunicação voltada para a discussão crítica dos vários modelos mentais (no limite individuais) envolvidos na análise de problemas.

A aprendizagem é entendida como processo individual de aquisição de conhecimentos e habilidades dependente da socialização e de processos de acoplamento com o meio, no sentido trabalhado por Maturana (1998) e por Piaget (apud Freitag, 1985) em relação ao processo de cognição em geral.

A aprendizagem como processo social corresponderia à superação do aprendizado fragmentado, que ocorre quando o aprendizado individual não implica na transferência de conteúdos para os grupos e organizações (ou no compartilhamento).

A subjetividade é, portanto, indissociável da intersubjetividade e se expressa na gestão por referência à última. Isto não implica sua dissolução ou anulação no ou pelo patrimônio social ou cultural. A diferença não pode ser negada, mas afirmada quando necessário.

A questão da liderança oferece um campo interessante para a reflexão sobre como características subjetivas e sociais ligadas à gestão organizacional se remetem mutuamente. Liderança é tanto uma capacidade individual como social, 
entendida a mesma tanto como resultado quanto como possibilidade da aprendizagem organizacional.

As capacidades de reflexão e de diálogo, de argumentação e de indagação, a capacidade de trazer à tona o não dito que condiciona a fala dos sujeitos organizacionais e de questionar os indiscutíveis de uma organização, o uso do planejamento de cenários como "lembrança do futuro" (análise dos filtros mentais que condicionam nosso olhar para o futuro) e aprendizado da capacidade de mudar, a análise de problemas como possibilidade de questionamento de nossas crenças são, entre outras, capacidades de aprendizagem que podem redundar em visões compartilhadas, superando o aprendizado fragmentado e gerando um saber comum que alimenta a cultura de uma organização.

A afirmação da individualidade e um distanciamento em relação à cultura podem significar, porém, a possibilidade da diferença inovadora.

\section{Algumas Técnicas da V Disciplina}

\section{A coluna da esquerda}

O objetivo desta técnica é tomar consciência dos supostos básicos que orientam nossa conversação e que contribuem para criar obstáculos em situações cotidianas, e desenvolver um modo de falar com mais clareza desses supostos.

Consta dos seguintes passos:

\section{Primeiro passo: escolher um problema}

Selecione um problema difícil que você tenha abordado recentemente, essas dificuldades interpessoais que muitos procuramos ignorar:

- não consegue chegar a um acordo com um colega;

- outra pessoa não se empenha suficientemente;

- você se acredita vítima de um trato injusto;

- $\quad$ você acredita que ninguém considera seu ponto de vista;

- a organização resiste (ou você acredita que resistirá) a uma mudança que você pretende implementar;

- você acredita que sua equipe não presta atenção ao problema fundamental. Escreva um parágrafo breve descrevendo a situação. Qual é o seu objetivo? Quem coloca entraves? O que poderia acontecer? 
Segundo passo: a coluna direita (o que foi dito)

Agora, lembre-se de uma conversação frustrante que você teve, ou imagine a conversação que você teria tido se tivesse tocado no tema.

Em um papel ou em vários, faça um quadro com duas colunas.

$\mathrm{Na}$ coluna da direita, escreva como foi o diálogo, ou anote-o como você acredita que seria se colocasse o problema. O diálogo pode continuar por várias páginas. Deixe a coluna esquerda em branco até terminar.

Terceiro passo: a coluna da esquerda (o que você pensava ou sentia)

Agora, na coluna da esquerda, escreva o que você pensava e sentia, mas não disse.

Quarto passo: reflexão (utilização da coluna da esquerda como recurso)

Podemos aprender muito ao registrar uma situação por escrito, guardar por uma semana e só então analisá-la. O caso se torna um instrumento que nos permite examinar nossos pensamentos como se fossem de outros.

Ao refletir, pergunte-se:

- O que me induziu a pensar e sentir dessa maneira?

- Qual era minha intenção? O que pretendia atingir?

- Alcancei os resultados que buscava?

- Como influenciaram meus comentários sobre as dificuldades?

- Por que não disse o que estava na coluna da esquerda?

- Que pressuposições tinha sobre a outra pessoa?

- Qual foi o preço de operar dessa maneira? Quais foram os frutos?

- O que me impediu de atuar de outra maneira?

- Como posso usar minha coluna da esquerda como recurso para melhorar nossas comunicações? 
Imagine minha interação com um colega, Bill, após ele ter feito uma apresentação extensa para nosso chefe, relativa a um projeto em que estamos trabalhando juntos. Não pude comparecer à apresentação, mas soube que havia sido mal recebida.

\section{$\mathrm{O}$ que estou pensando}

Todo mundo está dizendo que a apresentação foi 'uma bomba'. Será que ele sabe que foi ruim assim? Ou será que ele não está disposto a enfrentar o fato?.

Ele está realmente com medo de enfrentar a verdade. Se ele tivesse mais auto-confiança, provavelmente aprenderia alguma coisa com uma situação como esta.

Não posso acreditar que ele não perceba que a apresentação foi desastrosa para o prosseguimento do nosso trabalho.

Preciso achar um jeito de fazer este 'cara' acordar.

\section{O que é dito}

Eu : Como foi a apresentação?

Bill: Bom, não sei. É muito cedo ainda para dizer. Além do mais, estamos pisando em terreno novo.

Eu: Bom, o que você acha que a gente devia fazer? Creio que as questões que você levantou são importantes.

Bill: Não tenho tanta certeza assim. Vamos esperar e ver o que acontece.

Eu : Talvez você tenha razão, mas acho que talvez precisemos fazer mais do que simplesmente esperar

Fonte: Exemplo não problematizado apresentado por Senge et al., 1995.

\section{Os indiscutíveis}

Este exercício tem como objetivo aprender a partir de temas tabu, tão indiscutíveis que nem sequer se discute o fato de que sejam indiscutíveis.

Os passos são os seguintes: 


\section{Primeiro passo: compilando dados}

Cada participante da equipe recebe três cartões e canetas da mesma cor. Sem discussão nem colaboração, cada pessoa anota um problema indiscutível em cada cartão, descrevendo-o em detalhes para que todo mundo o entenda. Se a conduta de alguém faz parte do indiscutível, deve-se referir ao cargo e não ao nome da pessoa.

\section{Segundo passo: distribuindo os cartões}

Primeira opção: Alguém junta os cartões, embaralhando-os, e os distribui, ou faz uma pilha e deixa que a gente os extraia. Os membros da equipe colocam o cartão sobre a mesa, de cara para cima, à medida que os retiram da pilha.

Segunda opção: depois de cinco minutos, todos saem da sala, levando seus cartões. Um de cada vez, os membros da equipe entram na sala de reunião e escondem os cartões. Uma vez que todas tenham sido escondidas, as pessoas voltam para a sala e procuram achar três.

\section{Terceiro passo: revelando temas comuns}

Cada pessoa lê em voz alta os três cartões do passo 2 e os cola na parede. Quando todos os cartões tiverem sido lidas, os membros da equipe os agruparão por temas. A equipe deve decidir quantos temas serão abordados durante a reunião, deixando os outros para depois. É aconselhável começar pelos mais fáceis.

Estas perguntam ajudam a orientar o diálogo:

- Qual é a ameaça que se esconde atrás do indiscutível?

- Que modelo mental permitiu a persistência desta estrutura oculta?

- O que impede que este tema seja discutido com seriedade?

- Quais são as conseqüências indesejáveis do indiscutível, no passado, presente e futuro?

- Em que medida este indiscutível sustenta ou reduz nossa capacidade para a aprendizagem em equipe?

- Como se relaciona o indiscutível com a visão e os valores que subscrevemos?

- Que desejamos fazer com este indiscutível? 


\section{Perspectivas múltiplas}

O objetivo desta técnica é ampliar as perspectivas da equipe, os pontos de vista desde os quais seus membros examinam um problema. Trata-se de estimular a rotação de papéis de modo a permitir que os integrantes de uma equipe vejam um tema importante a partir da maior quantidade possível de perspectivas. Em primeiro lugar, deve definir-se o problema ou o tema a ser analisado e escrever em tarjetas o cargo ou a posição dos vários atores representados nesta equipe. Deveriam ser convocados os vários atores implicados no problema.

Os participantes tirariam, um de cada vez, um cartão da pilha embaralhada e se deslocariam para a posição representada por ela. Assumindo esta posição, eles fariam comentários sobre o problema, sobre como analisá-lo, e/ou sobre como abordá-lo. Os comentários devem ser necessariamente registrados.

Em algum ponto você se deparará com descrições completas de cada perspectiva. Nesse momento, a equipe pode comentar a situação desde cada uma delas. Podemos concluir, por exemplo, que a perspectiva do representante das finanças inclui três pontos de vista ou que a posição das finanças comporta três perspectivas. Cada uma dessas perspectivas poderá vir a ser analisada em separado, a partir de várias óticas.

\section{Escrevendo sendo leal}

O exercício tem dois objetivos: ajudar a identificar com maior clareza os modelos mentais que você tem acerca das pessoas-chave de sua organização e abordar uma dificuldade a partir de várias perspectivas. Também pode ajudar a adquirir habilidade política.

O exercício consiste em escrever três versões de um relatório ou memorando e em analisar em seguida as diferenças.

Você teria de escolher uma situação difícil com a qual se depara, sobre a qual escreverá um memorando. Enumere algumas pessoas às quais você espera ser leal quando escreva esse texto. Algumas podem ser simbólicas ou hipotéticas. Em seguida, escolha duas pessoas ou grupos de pessoas que leriam o texto quando concluído. Escolha, também mentalmente, sua lealdade à verdade tal como você a vê.

Escreva, inicialmente, uma descrição da situação como se a verdade fosse sua única lealdade. Utilize, de preferência, três parágrafos:

- Apresentação: Imagine que as pessoas lerão seu relatório em um futuro distante. De que maneira desejaria atrair sua atenção? O que poderia dizer de interessante para que elas continuassem lendo? O que você acha que as pessoas gostariam de saber primeiro? 
- Núcleo (parágrafo central): Aqui deve constar o núcleo do relatório : que ocorreu, a quem, onde, quando, por que e para quê? Que ocorreu, o que significa, quem participou?

- Encerramento (parágrafo final): O que é que você quer que as pessoas do futuro sintam quando tenham terminado de ler o relatório? Como espera que reajam? Qual é sua mensagem? O que lhe sugere o texto? Existe alguma moral da história ou algum plano de ação implícitos?

Quando tiver terminado, 'esqueça' o relatório por uns dois dias. Este trabalho será seu grupo-testemunha.

Escreva, agora, os relatórios correspondentes às duas pessoas escolhidas, pensando nas imagem das mesmas lendo as palavras do relatório. Aja como se não fosse mostrar a elas esses resultados. Observe a sugestão de três parágrafos, a partir das perguntas anteriores.

Você tem agora três relatórios. Analise-os pela primeira vez e responda a estas perguntas:

Observe primeiro o memo "à verdade" :

- Que impressão lhe causa o autor do memo?

- Que dados (do texto) o levam a esta conclusão?

- Que impressão você obtém apenas a partir do memo, da história e dos fatos respectivos? Quão importantes são estes fatos?

- Que frases específicas gerariam essa impressão?

Agora observe os outros dois memos (um depois do outro):

- Que impressão você obtém, a partir do primeiro memo, da pessoa A?

- Que parte do texto o leva a essa impressão? Por exemplo, que elementos figuram aqui que estão excluidos dos outros?

- Observando o parágrafo inicial, o que acredita o autor que interessará a $A$ ?

- O que o autor deseja que A ignore? Que dados ou detalhes são omitidos?

- A que conclusão o autor quer que chegue A? Como quer que reaja $A$ ?

- Agora imagine que você mostra o resultado a A. Aceitaria A o tipo de avaliação e as premissas? Ele se sentiria confortado ou mortificado?

- É possível verificar as premissas que levaram a essas respostas? Existe alguma razão pela qual possam não estar certas?

Você deve escrever, ainda, um relatório final a partir das três versões iniciais, escolhendo novos parágrafos a partir dessas. Concentre-se nessas versões e veja se é possível sintetizá-las. Revise esta versão final, levando em conta novas lealdades. Identifique as mudanças necessárias para tornar o memo 'digerível' para todos. 
Finalmente, entregue estas quatro versões às pessoas $\mathrm{A} e \mathrm{~B}$, perguntando a elas que versão prefeririam, que material deveria ser enfatizado na versão definitiva.

\section{Projetor e telas}

O objetivo deste exercício é observar a mente coletiva em ação; ver duas perspectivas polarizadas e aprender a distanciar-se de posições tradicionais rígidas. Cada participante representa o papel de alguém que enfrenta um dilema e dois pontos de vista sobre esse problema.

Um membro de cada equipe se propõe como projetor.Ele deve expor seu dilema e as duas alternativas. Este dilema deveria corresponder a algo real, iminente, a ser resolvido. O projetor escolhe que pessoa representará cada aspecto do dilema, atuando esta pessoa como tela sobre a qual projetará seus pensamentos.

As 'telas' devem compenetrar-se do papel atribuído, procurando debater o dilema não a partir de seu ponto de vista pessoal, mas a partir do ponto de vista que cada uma encarna (da melhor forma possível). O projetor fica em silêncio, refletindo.

O projetor comunica às 'telas' o que sentiu enquanto as escutava e os três membros de cada equipe começam a ver as pressuposições e pensamentos do dilema suspensos diante deles.

Finalmente, as várias equipes vão se reunir e fazer um resumo geral.

\section{Protocolos de discussão especialista (hábil)}

É útil escrever os protocolos em cartões para que os membros da equipe de discussão os tenham à mão durante as reuniões.

Sugestões para os conteúdos dos cartões:

- Preste atenção a suas intenções: O que desejo com esta conversação? Estou disposto a receber influências?

- Equilibre a argumentação com a indagação: $\mathrm{O}$ que o/a levou a esse ponto de vista ? O que significa esse ponto de vista?

- Elabore um sentido compartilhado: Quando usamos a palavra , o que queremos dizer?

- Fique consciente de sua reações: O que estou pensando? O que estou sentindo? $\mathrm{O}$ que quero neste momento? $\mathrm{O}$ que me impede de buscar o que eu quero? 
- Explore os estrangulamentos: Quais são nossos pontos de acordo e em que dissentimos?

Preparar o terreno para uma discussão deste tipo significa:

- Procurar um terreno neutro para discussão, onde não haja símbolos de poder e prestigio e os membros da equipe se tratem como colegas.

- Atuar de maneira a criar um clima de confiança e franqueza.

- Estimular e recompensar a introdução de novas perspectivas, incorporando eventualmente fontes externas de novas perspectivas

- Planeje bem a pauta (divulgada com antecedência) e o contexto da discussão, evitando distrações e uma jornada muito extensa.

O desenvolvimento da capacidade de escuta durante uma reunião deste tipo implica observar alguns requisitos:

- Deixe de falar com os outros e consigo mesmo. Aprenda a silenciar sua voz interior.

- Imagine o ponto de vista de outra pessoa. Coloque-se na posição do outro, no contexto do outro.

- Preste real atenção e demonstre interesse.

- Observe a conduta não-verbal para captar outros significados.

- Não interrompa. Aumente seu nível de tolerância.

- Busque as 'entrelinhas'. Leve em conta as figuras da linguagem. Capte as omissões do discurso, as coisas não ditas que, pela lógica, deveriam estar presentes. Pergunte sobre elas.

- Não critique enquanto escuta. Evite comentários críticos e intempestivos nesse momento. Limite-se a respostas construtivas até que o contexto tenha mudado e as críticas possam ser apresentadas sem que pareçam acusações.

- Escute ativamente, reproduzindo, com outras palavras, o que os outros disserem durante a conversa.

- Deixe de falar. Faça um voto de silêncio por um tempo.

\section{Aquário}

O objetivo desta técnica é afinar nosso estilo de comunicação em um âmbito de discussão especialista (hábil).

Descrição: a metade da equipe (o círculo interno) discute um tema, enquanto a outra (o círculo externo) observa. A crítica se realiza em duplas, não no grupo todo, de modo que as pessoas se sentem mais à vontade para trocar comentários. 
Aborde um tema difícil: um problema recorrente, uma racionalização, um fracasso, um “indiscutível"....

Passos:

\section{Primeiro passo: estabelecendo uma conexão}

Cada membro da equipe escolhe um colaborador em quem confie. Os colaboradores se sentam em duplas e se fazem as seguintes perguntas:

- Que opiniões contundentes você tem (como indivíduo) sobre este tema?

- Que dados observáveis (fatos, não opiniões) você pode trazer para a discussão?

- Está aberto a influências?

- Qual é a sua visão para um desfecho satisfatório da discussão?

O objetivo desta resenha é garantir que ambos os colaboradores entendam os supostos, valores e aspirações do outro.

\section{Segundo passo: grupo A, no centro (20 $\mathrm{min})$}

Disponha as cadeiras em dois círculos concêntricos, sem mesas.Um colaborador de cada grupo se integra ao grupo A e o outro ao B. Estes se revezam na conversa e na observação. Os falantes se sentam no círculo interno (grupo A) e iniciam a conversa. Seguem os protocolos da discussão especialista, definindo o tema e abordando-o do modo que considerem conveniente. Os membros do grupo B adotam o papel de observadores/instrutores. Sentam-se do lado dos colaboradores, de modo que possam ver-se e ouvir-se com facilidade. Quando seja a sua vez como observador/instrutor, use estas perguntas como parâmetros; tome nota sobre exemplos específicos (comentários incluídos) que ilustrem sua percepção da perícia do colaborador.

Quando seu colaborador argumentava, quantas vezes...?

- Expôs suas opiniões e idéias com tanta clareza que quem escutava podia vê-las mentalmente?

- Expôs as pressuposições nas que baseava suas opiniões e idéias?

- Contribuiu com dados observáveis para sustentar e esclarecer um raciocínio?

- Convidou os outros a enriquecer suas idéias?

- Absteve-se de ser defensivo quando o questionavam? 
Quando seu colaborador indagava, quantas vezes...?

- Fez perguntas sobre os supostos e dados que os outros traziam sem gerar uma atitude defensiva?

- Fez perguntas que aumentaram a compreensão do grupo sobre as opiniões de alguém?

- Escutou, suspendendo o julgamento (atentamente e sem interrupções), enquanto outros falavam?

Terceiro passo: a primeira crítica $(5 \mathrm{~min})$

Ao cabo de 20 minutos, dissolva o grupo e volte às duplas. Em cinco minutos, os observadores revisam suas notas com o falante. Ao fazer críticas, utilize os protocolos da discussão especialista. Por exemplo, ao invés de dizer 'você ficou na defensiva', diga: 'interpretei este comentário como defensivo'.

Quarto passo: refinamento e nova crítica (de 25 a $30 \mathrm{~min}$ )

O grupo A retorna à discussão. Ao final, o grupo B procede à crítica.

Quinto passo: grupo B no centro (duas sessões e duas críticas)

O grupo B assume o papel de falante e o grupo A de observador.

Sexto passo: auto-observação e resolução com todo o grupo

Todo o grupo delibera (após um descanso que permita refletir sobre as reações dos participantes ) sobre a competência do mesmo para gerar uma compreensão mais ampla de sua própria conduta e tenta chegar a um consenso resolutivo sobre a temática em pauta. 


\section{Protocolos de diálogo}

Exponha seus processos mentais (suba lentamente a escada de inferências) (Figura 1).

Figura 1 - Protocolos para melhorar a argumentação.

\begin{tabular}{|c|c|}
\hline Que fazer & Que dizer \\
\hline $\begin{array}{l}\text { Exponha suas premissas e descreva } \\
\text { os dados que o levaram às mesmas }\end{array}$ & $\begin{array}{l}\text { 'Eu penso da seguinte forma, e aqui está o } \\
\text { que me levou a pensar assim....' }\end{array}$ \\
\hline Explique suas premissas & 'Parti do pressuposto de que...' \\
\hline Torne explícito seu raciocínio & 'Assumi esta posição porque...' \\
\hline $\begin{array}{l}\text { Explique o contexto do seu ponto } \\
\text { de vista: quem será afetado pelas } \\
\text { suas propostas, como será afetado e } \\
\text { por quê }\end{array}$ & $\begin{array}{l}\text { 'Para ter uma imagem clara do que eu digo, } \\
\text { imaginem que vocês são a clientela que será } \\
\text { afetada...' }\end{array}$ \\
\hline $\begin{array}{l}\text { Forneça exemplos do que você } \\
\text { propõe, mesmo que sejam } \\
\text { hipotéticos ou metafóricos } \\
\text { Enquanto fala, tente imaginar a } \\
\text { perspectiva dos outros acerca do } \\
\text { que você diz }\end{array}$ & $\begin{array}{l}\text { 'Aqui estão alguns exemplos do tipo de } \\
\text { coisas que eu tinha em mente quando } \\
\text { cheguei a conclusão de que...' }\end{array}$ \\
\hline
\end{tabular}

Submeta suas conclusões e pressupostos ao julgamento dos outros.

\begin{tabular}{|l|l|}
\hline $\begin{array}{l}\text { Estimule os demais a explorar seu } \\
\text { modelo, suas premissas e seus dados }\end{array}$ & $\begin{array}{l}\text { 'Qual é sua opinião sobre o que acabei de } \\
\text { dizer?' } \\
\text { 'Identificou alguma falha no meu } \\
\text { raciocínio?' } \\
\text { 'Gostaria de acrescentar alguma coisa?' }\end{array}$ \\
\hline $\begin{array}{l}\text { Revele os detalhes que lhe pareçam } \\
\text { menos claros. Esta atitude, ao invés } \\
\text { de enfraquecê-lo, desativa a força } \\
\text { dos opositores e é um convite à } \\
\text { melhoria }\end{array}$ & $\begin{array}{l}\text { 'Eis aqui um aspecto que vocês poderiam } \\
\text { ajudar-me a resolver...' }\end{array}$ \\
\hline $\begin{array}{l}\text { Mesmo no meio de sua } \\
\text { argumentação, escute com atenção e } \\
\text { estimule os demais a apresentar suas } \\
\text { perspectivas }\end{array}$ & 'Alguém vê a situação de outra maneira?' \\
\hline
\end{tabular}

Fonte: Senge et al., 1995. 
Figura 2 - Protocolos para melhorar a indagação.

Peça aos outros que exponham seus modelos mentais.

\begin{tabular}{|l|l|}
\hline \multicolumn{1}{|c|}{ Que fazer } & \multicolumn{1}{c|}{ Que dizer } \\
\hline $\begin{array}{l}\text { Acompanhe os demais pela escada de } \\
\text { inferências e confira que dados } \\
\text { utilizam }\end{array}$ & $\begin{array}{l}\text { 'Como chegou a essa conclusão..?' } \\
\text { 'De que dados você dispõe para sustentar } \\
\text { essa conclusão..?' } \\
\text { 'O que o levou a dizer isso?' } \\
\text { 'Como isso se relaciona com seus } \\
\text { interesses..?' } \\
\text { 'Para onde vai seu raciocínio?' }\end{array}$ \\
\hline $\begin{array}{l}\text { Não seja agressivo na sua linguagem } \\
\text { com a gente não familiarizada com } \\
\text { esses métodos. Suas perguntas não } \\
\text { devem induzir a atitudes defensivas }\end{array}$ & $\begin{array}{l}\text { Ao invés de perguntar: 'A que você se } \\
\text { refere..? 'ou: 'Que provas você tem } \\
\text { disso..?', pergunte: 'Você pode me ajudar } \\
\text { a compreender suas idéias a respeito?' }\end{array}$ \\
\hline $\begin{array}{l}\text { Explique suas razões para a indagação } \\
\text { e como sua indagação se relaciona } \\
\text { com os seus próprios interesses, } \\
\text { expectativas e necessidades }\end{array}$ & $\begin{array}{l}\text { Pergunto quais são as suas premissas } \\
\text { porque...' }\end{array}$ \\
\hline $\begin{array}{l}\text { Induza os demais a explanar-se. } \\
\text { Confira por que dizem o que dizem }\end{array}$ & \\
\hline
\end{tabular}

Fonte: Senge et al., 1995.

Compare as próprias premissas com as alheias.

\begin{tabular}{|l|l|}
\hline $\begin{array}{l}\text { Verifique o que os outros dizem, } \\
\text { pedindo que contextualizem o dito e } \\
\text { que forneçam exemplos }\end{array}$ & $\begin{array}{l}\text { 'Isto é semelhante a?' } \\
\text { 'Quais seriam as conseqüências desta } \\
\text { proposta?' } \\
\text { 'Quem seria afetado por ela, como e por } \\
\text { quê?' }\end{array}$ \\
\hline $\begin{array}{l}\text { Verifique se vocês compreenderam o } \\
\text { que os outros disseram }\end{array}$ & $\begin{array}{l}\text { 'Será que entendi bem o que você disse?' } \\
\text { 'Se entendi corretamente, você está } \\
\text { dizendo que...' }\end{array}$ \\
\hline $\begin{array}{l}\text { Preste atenção à nova compreensão } \\
\text { que pode surgir. Não se empenhe em } \\
\text { destruir a argumentação do outro ou } \\
\text { em promover a própria }\end{array}$ & \\
\hline
\end{tabular}

Fonte: Senge et al., 1995. 
Figura 3 - Protocolos para lidar com um ponto de vista discordante.

\begin{tabular}{|l|l|}
\hline \multicolumn{1}{|c|}{ Que fazer } & \multicolumn{1}{c|}{ Que dizer } \\
\hline $\begin{array}{l}\text { Mais uma vez, pergunte ao outro } \\
\text { como chegou a esse ponto de vista }\end{array}$ & $\begin{array}{l}\text { 'Como chegou a essa conclusão?' } \\
\text { 'Você está levando em conta dados de que } \\
\text { eu não disponho?' }\end{array}$ \\
\hline $\begin{array}{l}\text { Confira se você realmente } \\
\text { compreendeu }\end{array}$ & $\begin{array}{l}\text { 'Vejamos se eu compreendi...Você está me } \\
\text { dizendo que...?' }\end{array}$ \\
\hline $\begin{array}{l}\text { Explore, escute, apresente sua } \\
\text { opiniões de maneira aberta. Esteja } \\
\text { alerta ao sentido mais amplo que } \\
\text { pode surgir da exposição franca de } \\
\text { outros modelos mentais }\end{array}$ & 'Você já pensou em...?' \\
\hline $\begin{array}{l}\text { Utilize sua coluna da esquerda como } \\
\text { recurso }\end{array}$ & $\begin{array}{l}\text { 'Quando você diz... Preocupo-me } \\
\text { porque...ou temo que isso implique...' }\end{array}$ \\
\hline $\begin{array}{l}\text { Manifeste suas preocupações e } \\
\text { esclareça o motivo de tê-las }\end{array}$ & $\begin{array}{l}\text { 'Tenho grande dificuldade em entender } \\
\text { isso porque...' }\end{array}$ \\
\hline
\end{tabular}

Fonte: Senge et al., 1995.

Figura 4 - Protocolos para momentos de estrangulamento.

\begin{tabular}{|l|l|}
\hline \multicolumn{1}{|c|}{ Que fazer } & \multicolumn{1}{|c|}{ Que dizer } \\
\hline $\begin{array}{l}\text { Admita que há um impasse e } \\
\text { procure superá-lo com humor( (a } \\
\text { concentração nos dados pode guiá- } \\
\text { lo pela escada de inferências) }\end{array}$ & $\begin{array}{l}\text { 'Que sabemos com certeza?’ } \\
\text { 'Existe algo que nos pareça certo, mas que } \\
\text { não esteja confirmado pelos dados?’ }\end{array}$ \\
\hline $\begin{array}{l}\text { Busque informação que nos ajude a } \\
\text { ir em frente }\end{array}$ & $\begin{array}{l}\text { 'Que coisas estamos ignorando?’ } \\
\text { 'O que é impossível de conhecer ?' }\end{array}$ \\
\hline $\begin{array}{l}\text { Pergunte se não há uma forma de } \\
\text { desenhar juntos um experimento ou } \\
\text { uma indagação que proporcione } \\
\text { novas informações. Escute as idéias } \\
\text { como se fosse a primeira vez. }\end{array}$ & $\begin{array}{l}\text { 'Em que pontos concordamos e em que } \\
\text { pontos discordamos?’ }\end{array}$ \\
\hline $\begin{array}{l}\text { Considere o modelo mental da outra } \\
\text { pessoa como um fragmento de um } \\
\text { quebra-cabeças maior }\end{array}$ & $\begin{array}{l}\text { 'Estamos partindo de dois pressupostos } \\
\text { muito diferentes?' }\end{array}$ \\
\hline $\begin{array}{l}\text { Pergunte que dados ou que lógica } \\
\text { poderiam modificar essas } \\
\text { perspectivas }\end{array}$ & $\begin{array}{l}\text { 'O que teria que acontecer para você } \\
\text { considerar uma alternativa.?’ }\end{array}$ \\
\hline $\begin{array}{l}\text { Peça a ajuda do grupo para re- } \\
\text { elaborar a situação. Não permita que } \\
\text { a conversação se detenha com “um } \\
\text { acordo sobre o desacordo” }\end{array}$ & $\begin{array}{l}\text { 'Parece que chegamos a um impasse e } \\
\text { receio que sairemos daqui sem nos } \\
\text { entender... Alguém tem idéias que nos } \\
\text { ajudem a esclarecer o nosso pensamento?’ }\end{array}$ \\
\hline $\begin{array}{l}\text { Evite promover seus argumentos } \\
\text { quando alguém fala desde outro } \\
\text { ponto de vista }\end{array}$ & $\begin{array}{l}\text { Não compreendo o porquê de nossa } \\
\text { desavença.' }\end{array}$ \\
\hline
\end{tabular}

Fonte: Senge et al., 1995. 


\section{Estratégias para Enfrentar Desafios da Mudança Organizacional}

No livro A Dança das Mudanças (2000), Senge e os outros autores assumem como objetivo apresentar técnicas e estratégias que possam ajudar a equacionar uma série de desafios que o processo de transformação organizacional comportaria. Alguns destes desafios seriam: a falta de tempo dos dirigentes e gestores da mudança; a carência de esquemas de ajuda ou de tutoria dos grupos envolvidos no processo; a dificuldade de apresentar a mudança como questão relevante; os obstáculos à difusão das informações e dos resultados inerentes ao processo; um certo isolamento e espírito de arrogância dos grupos-piloto que leva a uma polarização entre fanáticos da mudança e descrentes; a incapacidade de agir conforme o discurso; o medo e a ansiedade inerentes a todo processo de transformação; a dificuldade de formular indicadores do processo de apreciação e medição da mudança; o desafio de adquirir maior autonomia enquanto grupo-piloto da mudança e de passar a ser parte do esquema de poder reconhecido pelo organização (governança); o desafio de possibilitar uma permanente definição crítica da estratégia e do propósito organizacionais.

Diante destes desafios, alguns princípios estratégicos podem ser articulados:

\section{A necessidade de flexibilizar o tempo}

A questão fundamental é como gerar mais tempo para permitir uma concentração maior nos processos inovadores e de mudança.Isto dependeria de várias orientações:

- Confiar às pessoas uma possibilidade maior de controle de uso do próprio tempo, como condição de possibilidade de níveis maiores de confiança.

- Valorizar o tempo não estruturado, um tempo "livre" voltado para a reflexão e o diálogo, para o "sonhar acordado" individual e coletivo, para a discussão dos aspectos ambíguos da estratégia, da mudança e da aprendizagem informal, para a busca de maior inovação e de maior coesão organizacionais.

- Procurar integrar várias iniciativas diferentes em uma única, especialmente quando estas demandam capacidades relacionadas para a mudança.

- Dizer não à politicagem, ao jogo de poder e ao lixo burocrático.

- Desenvolver uma maior concentração estratégica sobre aqueles aspectos ligados às iniciativas de mudança, gerando a capacidade de dizer não às 
questões não essenciais e de eliminar tarefas desnecessárias. Isto implica uma conformação racional da agenda que supõe algumas técnicas: examinar se os compromissos assumidos para os próximos meses tem a ver com elementos da visão organizacional (para você mesmo, para o grupo-piloto da mudança e para a organização) ou não; avaliar, com colaboradores próximos, uma listagem de aspectos a que o dirigente dá atenção demais e de aspectos a que o mesmo não dá atenção suficiente ; questionar-se acerca das tarefas com as quais você não gostaria de se preocupar, delegando-as, das tarefas que você não deveria fazer, e das tarefas com as quais poderia lidar com muito menos supervisão; classificar as iniciativas ou sugestões de alternativas de ação de acordo com a facilidade de realização e o impacto sobre a organização.

- Esta capacidade de flexibilização implica em poder parar algo antes de começar algo novo e em abandonar determinadas atividades consideradas relevantes (mesmo após uma depuração) por um certo tempo, para concentrar-se no que seria relativamente mais importante ("negligência planejada").

\section{A necessidade de ser um exemplo de abertura e de cultivar a moderação e o gradualismo para combater o medo e a ansiedade inerentes à mudança}

O medo e a ansiedade derivariam de um "hiato de abertura", de uma tensão entre as crescentes exigências de franqueza e de abertura do grupo envolvido e as reais capacidades das pessoas de toda a organização. Estes sentimentos poderiam ser enfrentados com as seguintes estratégias:

- O dirigente tem de ser um exemplo de abertura, no sentido de reconhecer sua vulnerabilidade, sua capacidade de cometer erros que devem ser encarados como oportunidades. O comprometimento com a verdade e a aceitação da diversidade como algo de valor, dentro de um ambiente de escuta das várias visões, colaboram para aumentar a confiança das pessoas e para estimular sua própria liderança.Da mesma maneira opera a percepção de que a participação em processos de mudança é uma questão de escolha e não de coerção.

- É melhor começar pequeno e tomar impulso antes de confrontar-se com situações difíceis. É mais eficaz ir aos poucos, lidando com pequenos medos e ansiedade e construindo a capacidade durante a longa caminhada na direção dos grandes medos e ansiedades.

- Evite "investidas frontais". O medo não pode ser "expulso" ou dominado. O que se pode fazer é criar condições favoráveis para o surgimento grada- 
tivo da confiança, considerada um aspecto essencial da dinâmica organizacional. Tal situação depende do estabelecimento lento de redes de ajuda entre as pessoas com base no entendimento interativo e na oferta por parte da direção de uma malha de segurança psicológica.

- Como dirigente, evite atirar nos seus próprios pés ao pretender radicalizar o processo de mudança ("agora ou nunca")e exigir das pessoas condutas avançadas, absolutamente transparentes e dialógicas.

- Como dirigente, você deve deixar claro que espera um progresso constante, mas que você também sabe que haverá retrocessos e desventuras. Isto corresponde a não querer diminuir o hiato entre o "onde estamos" e o "onde queremos estar" de uma só vez, mas pouco a pouco.

- Lembrar permanentemente que o medo e a ansiedade são respostas naturais e que a inexistência deles é indicativo de falta de aprendizagem (de falta de dúvidas) e de pouco avanço (ou de direção incorreta) no processo de mudança.

\section{A necessidade de sensibilizar estrategicamente os gerentes- chave acerca da relevância da mudança e de construir a capacidade de se entrosar com a organização como um todo desde 0 início}

A possibilidade de evitar um engajamento fanático que leve ao isolamento diante de manifestações naturais de descrença organizacional e a solidificação da idéia da relevância do "deve ser" do processo de mudança dependem de várias estratégias:

- Buscar, desde o início, apoio nos níveis da gerência instituída e trabalhar em parceria representam antídotos para a sensação de "falta de ajuda" que acomete os processos de mudança.

- Tornar-se "bicultural": a liderança da mudança deve saber proteger as iniciativas de mudança, ciente de que elas precisam de "incubadoras" para se desenvolverem, mas deve, ao mesmo tempo, saber aprender da experiência da tradição. Em grande medida, a eficácia da mudança depende da possibilidade de trânsito ou de cruzamento de fronteiras entre a subcultura emergente e a cultura pré-existente. Ou da possibilidade de comportar-se nos termos definidos pelas chefias e simultaneamente estimular, nos grupos envolvidos na mudança, habilidades em desafiar verdades e acreditar.

- Desenvolver a negociação e a diplomacia de modo a incorporar no processo os vários afetados e construir ligações mais permanentes com toda a 
organização. Os grupos inovadores mais bem-sucedidos correspondem àqueles que desenvolvem uma "orientação para fora", ao invés de se concentrarem exclusivamente no desenvolvimento interno. Dentro deste espírito, é importante ter paciência com os chefes e procurar fazer com que as prioridades dos grupos executivos façam parte do pensamento criativo do seu grupo.

- Cultivar a franqueza reflexiva ou a disposição para saber lidar produtivamente com o conflito, no sentido da possibilidade da criatividade, é um anteparo para a tendência à arrogância. Da mesma maneira, assumir que você não tem de convencer as pessoas é um desafio correspondente a ensejar a possibilidade da coexistência de "múltiplas realidades" como estratégia de liderança.

\section{Saber cruzar fronteiras}

A governança depende essencialmente da capacidade de saber cruzar estrategicamente as fronteiras, da possibilidade de trabalhar com grupos multifuncionais (e de transformar os mesmos de grupos temporários em grupos mais permanentes de poder), e do desenvolvimento de estruturas específicas que a protejam de "ficar à mercê" do autoritarismo.

A governança depende das questões anteriores relativas à relevância da mudança e a como evitar o isolamento, e de outras orientações, tais como:

- A liderança da mudança deve desenvolver a capacidade de perceber suas próprias fronteiras e programar uma expansão gradual de sua influência no sentido de encontrar ligações com a estrutura de governança existente. Esta expansão depende, em boa parte, do desenvolvimento de um espírito de investigação dos efeitos que os projetos inovadores ocasionam em outras áreas e da disposição para convidar essas áreas a problematizar esses efeitos. Quando se trabalha com um grupo multidimensional de várias áreas da organização, um esforço especial deverá ser feito no sentido de responsabilizar os gerentes dessas áreas. Saber atravessar fronteiras delicadas depende da capacidade de reconhecimento das mesmas, do diálogo e da capacidade de responsabilizar as outras áreas.

- A criação de colegiados de gestão e de comitês de consulta, assim como o desenvolvimento da supervisão geral de suporte ao micro gerenciamento, são estratégias permanentes de confrontação das tendências de refluxo à hierarquia.

- É importante na busca de uma desconcentração de poder realizar experiências com grupos multifuncionais. Evite falar sobre conexões permanentes 
inicialmente ;isto poderia assustar. Primeiro demonstre resultados, para a seguir negociar uma transição do grupo temporário para algo permanente, patrocinado pelos superiores.

- Nunca subestime o poder de pequenas mudanças em situações complexas - se elas forem as mudanças certas. As questões de governança, como as questões de mudança social, são desencorajadoras porque são complexas. Pequenos ganhos, por exemplo no nível da autonomia local, podem fazer uma grande diferença, de modo que essas questões devem ser colocadas.

- A base da governança é se preparar para uma longa viagem, não embarcando sozinho. Desenvolver um projeto de governança na base da visão é um processo árduo de construção de consenso. Deste processo deve fazer parte se não todo, pelo menos parte do sistema de poder executivo vigente. A construção do consenso não significa unanimidade, mas solidariedade, harmonia, colaboração, para buscar soluções comuns. O processo é inevitavelmente lento e cheio de concessões ao passado, pois o autoritarismo é um traço forte e os vários grupos envolvidos muito diferenciados. Avançar mentalmente rumo ao autocontrole é um processo que requer muita maturidade, que supõe um questionamento contínuo da idéia fácil da governança como controle externo. O desafio é estabelecer um projeto de governança que dificulte que qualquer um faça as coisas funcionarem em causa própria. Isto implica projetar sem ter uma idéia dos seus futuros papéis, afastando o autofavorecimento.

\section{Difusão da importância do processo e dos resultados inovadores}

Em boa medida, a eficácia do processo de mudança depende da possibilidade de difundir a todos os setores da organização a ordem de importância do processo e os resultados inovadores apresentados. O desafio da difusão comporta algumas estratégias, como:

- Reconhecer e explorar os líderes de rede, os grupos de líderes que apresentam alta capacidade de transferência de conhecimentos e habilidades, e de produção de idéias inovadoras.

- Desenvolver a capacidade de colocar "todo o sistema" em uma sala, de mobilizar todas as partes para um processo de indagação coletiva, especialmente sobre questões relacionadas a como estão criando coletivamente situações nas quais ninguém vence. $\mathrm{O}$ objetivo deste processo é ajudar a 'cimentar' a percepção de que nossas ações dependem das ações dos outros, assim como podem causar problemas para os outros. 
- Aprender a divulgar informações sobre inovações com menos restrições, buscando não estimular a competitividade, mas criar um "mercado aberto" para a inovação, apoiada na colaboração.

- Fazer da pesquisa e da experimentação e da pesquisa uma responsabilidade executiva, partindo da pressuposição de que a criação de conhecimento e de inovação representa uma vantagem competitiva, na medida em que as novas idéias sejam implementáveis.

- Tentar derrubar as fronteiras organizacionais através do desenvolvimento de um tipo de "indagação apreciativa", que assim como o processo de negociação consiste em uma aproximação à problemática do outro que implica colocar-se na situação do outro e em saber perguntar e questionar para permitir a evolução da posição do outro.

- A difusão é também uma questão de usar a linguagem conscientemente, buscando ser compreendido pelos demais.

\section{Fazer da apreciação uma prioridade}

O processo de mudança exige o desenvolvimento de formas de medição do avanço. Basicamente, o desafio da medição comporta a necessidade de fazer da apreciação e do desenvolvimento de novas capacidades de apreciação uma prioridade entre os defensores da mudança. A questão central consiste em gerar esta "cultura" a partir da criação de um sentido de responsabilidade sobre a avaliação, o qual subentende definições participativas. A necessidade de aprender a reconhecer e apreciar o progresso da mudança está ligada à apresentação de resultados que ajudem a alavancar o mesmo, criando novos níveis de motivação. Há o desafio de produzir consensualmente indicadores de apreciação diferentes dos tradicionais e de aprender a apreciar as defasagens de tempo envolvidas na mudança profunda, pois os resultados as vezes não são imediatos. A problematização que deveria acompanhar o reconhecimento destas defasagens é um instrumento importante de aprendizado do raciocínio sistêmico. 


\section{Discussão da estratégia e do propósito como possibilidade coletiva. A necessidade de desenvolver a questão da discussão da estratégia e do propósito como uma possibilidade coletiva, entendendo a estratégia como conversação}

Algumas estratégias podem ser visualizadas para enfrentar este desafio:

- Usar o "pensamento por cenários" para investigar pontos cegos e sinais de acontecimentos inesperados. O recurso a este enfoque se explica pela necessidade de criar nas pessoas uma maior abertura de posições, ao mostrar a possibilidade de vários futuros, alicerçados em várias premissas diferentes. Desta maneira, criar-se-ia uma tensão contrária a defesa irrestrita, fixa, de posições. Os cenários não seriam encarados, então, como previsões.

- Combinar o pensamento por cenários com a exploração do propósito organizacional. Combinar a reflexão sobre cenários (trazendo à tona as forças externas que podem afetar o futuro) com a visão compartilhada (aspirações coletivas das pessoas organizacionais) pode trazer alívio às escolhas que a organização tem de fazer e ao impacto que essas escolhas podem ter. A questão desafiadora consiste em mostrar um "caminho para cima" (o voluntarismo propositivo da visão) e um "para baixo" (de induções contextuais), contrastados, procurando fazer com que as pessoas gravitem em direção ao caminho para cima, construindo escolhas fundamentadas no contexto e apoiadas na intenção de agir sobre o mesmo como condição para a produção de circunstâncias favoráveis á visão.

- Assumir que o foco consiste em melhorar a capacidade de pensamento estratégico e pensamento ético. O objetivo do planejamento não seria produzir as melhores estratégias e planos, mas estimular o envolvimento de todos em processos conversacionais que ajudem a desenvolver capacidades de aprendizagem e de raciocínio estratégico, e a construir escolhas apoiadas no critério legitimidade.

- Assumir que o mais importante é expor e testar as premissas subjacentes às estratégias. Isto significa que as estratégias, como os cenários, não podem ser vistas como previsões deterministas, mas como apostas fundamentadas em uma série de argumentos sobre os atores aliados e oponentes, sobre as necessidades e problemas da situação, sobre o impacto das ações etc.. A qualidade da análise desses argumentos é de fundamental importância para a escolha das estratégias. 


\section{Referências Bibliográficas}

AMATUCCI, M. Aprendizado organizacional: encontro de tradições aponta para o futuro. In: LAS CASAS, A. Novos Rumos da Administração. Petrópolis: Vozes, 1999.

ARGYRIS, C. Double-loop learning in organizations. Harvard Business Review, 2(4), set/out.1977

BOYETT, J. O Guia dos Gurus. Os Melhores Conceitos e Práticas de Negócios. Rio de Janeiro: Campus, 1999.

FREITAG, B. Piaget. Encontros e Desencontros.Rio de Janeiro: Tempo Brasileiro, 1985.

GEUS, A. P. Planejamento como aprendizado. In: STARKEY, K. (Org.) Como as Organizacõos Aprendem. Relatos do Sucesso das Grandes Empresas. São Paulo: Zumble/Futura, 1997.

GRUPO ZUMBLE CONSULTORIA. Seção aprendizagem organizacional. Disponível em <http://www.zumble.com.br>. Acesso em 18/06/2001.

HABERMAS, J. Teoria de la Acción Comunicativa. Madri: Taurus, 1987.

KIM, D. Administrando os ciclos de aprendizado organizacional. In: WARDMAN, K. T. (Org.) Criando Organižações que Aprendem. São Paulo: Zumble/Futura, 1996.

KIM, D. Loops de criação de paradigmas: como as percepções moldam a realidade. In: WARDMAN, K. T. (Org.) Criando Organizações que Aprendem. São Paulo:Zumble/Futura, 1996.

MATUS, C. Política, Planejamento e Governo. Brasília: Ipea,1993.

MATURANA, H. Emoções e Linguagem na Educação e na Politica. Belo Horizonte: EditoraUFMG, 1998.

MITROFF, I.Tempos Dificeis.Soluçöes Inovadoras. A Arte de Fazer as Perguntas Certas $e$ Resolver os Problemas Certos. Rio de Janeiro: Campus,1999.

MOT'TA, P. R. Gestão Contemporânea. A Ciência e a Arte de Ser Dirigente. Rio de Janeiro: Record, 1991.

SCHEIN, H. E. Guia de Sobrevivência da Cultura Corporativa. Rio de Janeiro: José Olympio, 2001.

SENGE, P. O novo trabalho do líder. In: STARKEY, K. (org.) Como as Organizações Aprendem. São Paulo: Zumble/Futura,1997. 
SENGE, P. et al. La Quinta Disciplina en la Práctica. Estrategias y Herramientas para Construir la Organización Abierta al Aprendizaje.Barcelona: Granica, 1995.

SENGE, P. et al. A Dança das Mudanças. Os Desafios de Manter o Crescimento e o Sucesso em Organizações que Aprendem. Rio de Janeiro: Campus/Zumble, 2000.

RIVERA, F. J. U. Cultura e Liderança Comunicativa - A Gestão pela Escuta 1. Ensp/Fiocruz, 2000a. (Mimeo.)

RIVERA, F. J. U. Reflexões sobre a Organização que Aprende - A Gestão pela Escuta 3 -Algumas Ferramentas Lúdico-Pragmáticas. Ensp/Fiocruz, 2000b (Mimeo.)

\section{Anexo: Arquétipos de sistemas de mais ampla e difundida relevância (Senge, 1997)}

- Equilibrando processos com atraso: Neste arquétipo, os tomadores de decisões deixam de considerar os atrasos envolvidos à medida que rumam em direção ao objetivo. Como resultado, eles ultrapassam o objetivo, podendo até gerar ciclos recorrentes. Exemplo clássico: construtoras que não param de iniciar novos projetos até que o mercado começa a se estabilizar, momento em que os projetos ainda em construção já representam excesso de oferta.

- Limites ao crescimento: Um ciclo de reforço de crescimento pára, podendo até mesmo se reverter, ao se aproximar dos limites. Tais limites podem ser de insuficiência de recursos ou repostas externas ou internas ao crescimento. Exemplos clássicos: ciclos de vida de produto que atingem prematuramente seu máximo por baixa qualidade ou serviço precário, o crescimento e queda da comunicação numa equipe gerencial, e a difusão de um novo movimento.

- Transferencia de responsabilidade: Uma "solução" de curto prazo é usada para corrigir um problema, com resultados imediatos aparentemente positivos. À medida que esse corretivo é usado outras vezes, as medidas corretivas fundamentais de longo prazo são cada vez menos usadas. Com o tempo, os mecanismos de solução fundamental podem se atrofiar ou se perder, intensificando ainda mais o uso de soluções sintomáticas. Exemplo clássico: usar pessoal de recursos humanos para resolver problemas locais de pessoal, impedindo assim que os gerentes desenvolvam habilidades interpessoais próprias. 
- Metas declinantes: Quando nada mais funciona, abaixe os seus padrões. Algo parecido com a "transferência de responsabilidade", exceto pelo fato de que a solução imediatista envolve deixar que um objetivo fundamental, tal como o padrão de qualidade ou nível do moral dos funcionários, se atrofie. Exemplo clássico: empresa que responde aos seus problemas de entrega dilatando continuamente seus prazos de entrega estimados.

- Escalada: Duas pessoas ou duas organizações, as quais vêem seu bem-estar como dependente de uma relativa vantagem sobre a outra, reagem continuamente aos avanços da outra. Sempre que um dos lados avança, o outro se sente ameaçado, sendo levado a agir mais agressivamente para reconquistar sua vantagem, o que faz com que outro se sinta ameaçado, e assim por diante. Exemplos clássicos: corrida armamentista, guerras entre gangues, guerras de preços.

- Tragédia dos comuns: Indivíduos continuam intensificando seu uso de um recurso comumente disponível porém limitado, até que todos começam a ter retornos cada vez menores. Exemplos clássicos: criadores que não param de aumentar seus rebanhos até que eles acabam com o pasto compartilhado; divisões de uma empresa que compartilham uma equipe de vendas e que competem pelo uso dos vendedores mediante a elevação das suas metas de vendas, até que a equipe de vendas se exaure por sobrecarga.

- Crescimento e subinvestimento: O crescimento rápido se aproxima de um limite que poderia ser eliminado ou empurrado para o futuro, porém somente através de substancial investimento sem recursos físicos e humanos. As metas ou padrões declinantes ocasionam investimentos muito pequenos, ou muito lentos, e os clientes vão ficando cada vez mais insatisfeitos, desacelerando o crescimento da demanda, fazendo o investimento requerido (aparentemente) desnecessários ou impossível. Exemplo clássico: incontáveis empresas, outrora passando por um bem-sucedido crescimento, que permitiram o declínio da qualidade dos produtos ou serviços e foram incapazes de gerar suficiente receita para investir em corretivos. 

Anexo:

\section{A gestão estratégica hospitalar}

\section{Roteiro para a Análise Estratégica do Perfil Assistencial das Especialidades Médicas}

Este documento é uma tentativa de adaptação e de simplificação do guia da démarche estratégica francesa, metodologia de definição da missão hospitalar, idealizada por M. Cremadéz e F.Grateau e aplicada pelo Centro Hospitalar Regional e Universitário de Lille (CHRU). Contém um roteiro de preenchimento das principais matrizes ou formatos do enfoque e o conjunto dos formatos ou instrumentos propriamente ditos. Os 14 formatos se referem às principais fases do método:

- Análise do Existente

- Segmentação Estratégica

- Análise da Posição Estratégica (Valor e Competitividade) dos Segmentos

- Porta-fólio de Atividades e Estratégia

- Plano de Ação

\section{Análise do existente}

É a primeira fase da démarche estratégica. É um diagnóstico que consiste de vários elementos:

- uma descrição das patologias tratadas e das tecnologias atualmente utilizadas na especialidade, assim como de suas relações;

- uma descrição das modalidades assistenciais da oferta de atividades por especialidade; 
- uma descrição da distribuição da oferta de atividades por especialidade e por segmento (quando necessário), considerando a rede de serviços de saúde da área;

- uma descrição dos parceiros e dos concorrentes por segmento.

\section{Levantamento de patologias e tecnologias}

\section{Patologias (formato I)}

Este inventário permite conhecer as atividades do serviço. Devem ser descritas todas as patologias tratadas desde as mais simples até as mais complexas. Pode-se indicar o tipo genérico de atividade envolvido no enfrentamento das patologias. Por exemplo: diagnóstico, acompanhamento, tratamento, atividade pedagógica, nível de complexidade pertinente etc.

\section{Tecnologias (formato 2)}

Este inventário inclui equipamentos, técnicas de apoio diagnóstico e terapêutico, técnicas pedagógicas ou atividades educativas, tecnologias de trabalho assistencial em equipe multiprofissional, o parecer de experts de outras especialidades, ou ainda, para os serviços de Medicina, o savoir-faire de um cirurgião cuja colaboração represente uma competência distintiva da especialidade (suporte em conhecimento de outras especialidades).

\section{Distribuição da oferta de atividades por especialidade pela rede de serviços}

Consiste em relacionar as atividades realizadas na especialidade do hospital-sede da aplicação do enfoque, aquelas atividades realizadas fora da especialidade (embora pertinentes à mesma) mas no mesmo hospital, aquelas realizadas fora do hospital e finalmente as atividades não disponíveis na área de referência, que podem ser necessárias. Neste roteiro, adaptou-se este item, tendo em vista a aplicação do enfoque na AP2.1 da cidade do Rio de Janeiro, com a finalidade primordial de coordenar atividades entre os hospitais da Lagoa e de Ipanema, sem perder de vista o conjunto. Neste contexto, o formato específico de levantamento de informação proposto (formato 3) consta de quatro quadrantes: um referente à listagem dos conjuntos agregados de atividades realizadas na especialidade do hospital-sede (Lagoa), outro à das atividades do hospital de Ipane- 
ma, o terceiro referente às atividades dos outros hospitais da rede (se necessário discriminar) e o quarto referente a atividades não disponíveis, porém necessárias.

Em relação à distribuição da oferta, propõe-se ainda um outro formato, que consiste em determinar as atividades típicas do hospital, as atividades típicas da concorrência, o que é comum e as atividades não disponíveis na área (formato 4).

Quando necessário, sugere-se a realização do mesmo tipo de levantamento por segmento de atividade. Isto supõe utilizar os formatos 3 e 4 após a segmentação estratégica, assumindo como unidade de comparação cada segmento de atividade.

\section{Cruzamento entre patologias e tecnologias (formato 5)}

Este quadro estabelece a relação existente entre patologias e tecnologias a partir dos subconjuntos identificados nos quadros anteriores, especificamente os formatos 1 e 2 .

Indicaremos aqui as tecnologias específicas a determinadas patologias dentro da matriz correspondente. Para tanto, utilizaremos a simbologia conforme segue:

- D - Tecnologia utilizado no diagnóstico e/ou acompanhamento

- $\mathrm{T}$ - Tecnologia utilizada no tratamento

Poderemos, também, representar a freqüência da utilização da tecnologia da seguinte maneira:

- $\mathrm{D}+/ \mathrm{T}+$ - Utilização quase sistemática

- $\mathrm{D} \pm / \mathrm{T} \pm$ - Utilização freqüente (em torno de 50\%)

- D-/T- - Utilização excepcional

\section{Análise das modalidades de atendimento}

Esta matriz está destinada a identificar as características assistenciais das diferentes atividades das tabelas anteriores e definir subgrupos homogêneos de atividades em termos da prática médica. Os critérios da análise das modalidades são:

\section{Programabilidade}

- Eletivo - Podemos considerar como eletivo todo ato que possa ser previsto com três dias de antecedência ou articulado a um ato que possa ser previsto com três dias de antecedência. 
- Não-Eletivo - Podemos considerar não-eletivo todo ato que não possa ser previsto ou programado com três dias de antecedência.

\section{Necessidade de hospitalização}

- H - Hospitalização de um ou mais dias necessária

- $\quad \mathrm{NH}$ - Hospitalização não necessária

\section{Duração da hospitalização}

- D - Hospitalização igual ou inferior a 24 horas

- S - Hospitalização superior a 24 horas e inferior a 5 dias

- SS - Hospitalização superior a 5 e inferior a 15 dias

- $\quad$ P - Hospitalização superior a 15 dias

\section{Necessidade de tecnologia}

- In - Tecnologia disponível no Serviço

- $\mathrm{SH}$ - Tecnologia disponível em outro serviço do hospital

- Ex - Tecnologia não disponível no hospital, compartilhada com outros serviços externos

A análise das modalidades assistenciais implica o preenchimento prático de duas matrizes:

- matriz de segmentação de patologias (formato 6)

- matriz de segmentação de tecnologias (formato 7)

\section{Relacionar os parceiros e concorrentes por segmento (formato 9)}

Consiste em relacionar as instituições que realizam atividades comuns ou específicas referidas ao segmento, classificando-as em parceiras ou concorrentes. É importante destacar que este item pressupõe a realização da segmentação estratégica (fase seguinte). 


\section{A Segmentação Estratégica (formato 8)}

O objetivo desta etapa é definir subgrupos homogêneos de atividade, chamados segmentos. Estes seriam os produtos básicos de uma especialidade (formato 6).

A segmentação é uma análise multicritérios, que visa a avaliar as semelhanças e diferenças entre as atividades existentes em uma especialidade. Cada um dos subgrupos escolhidos deve compreender um grupo de atividades caracterizadas pelas semelhanças em função dos critérios de análise. Estes critérios, embora numerosos a priori, são reduzidos, na prática, a um elenco mais limitado. Este recorte é situacional, ou seja, depende do projeto político da direção de cada hospital (e da coordenação da Área Programática), dos projetos e motivações dos profissionais das especialidades envolvidas, das necessidades de diferenciação estratégica em função dos referidos projetos/objetivos e, ainda, das demandas/necessidades levantadas na área populacional atendida pelos hospitais.

Os critérios de segmentação são:

- as patologias: tipo e localização da patologia, nível de complexidade, imbricações;

- as condições de atendimento: necessidade de internação convencional ou específica (leitos de isolamento), programabilidade;

- as tecnologias implementadas: necessidade de dispor de uma capacidade técnica específica;

- as competências requeridas: grau de sofisticação dentro da especialidade, recurso à competência de diversos especialistas;

- a concorrência: número de profissionais exercendo a atividade e meios a sua disposição;

- o tipo de população envolvida (idade...);

- olugar da atividade em uma rede de cuidados: emergência, diagnóstico, tratamento, acompanhamento, educação e prevenção.

Ao final do processo de segmentação, será necessário verificar que nenhum elemento importante de heterogeneidade subsista dentro de cada segmento definido, e que, ao contrário, não exista similitude muito flagrante entre dois segmentos.

Um segmento estratégico validado será composto de atividades que podem ser avaliadas globalmente sob o prisma do interesse que representam para o hospital e sob o ângulo das competências necessárias para se ter uma posição de excelência. 


\section{Análise do Valor ou da Capacidade de Atração do Segmento (formato 10)}

A análise do valor supõe uma análise multicritérios, orientada por perguntas específicas. Os critérios valorados são:

\section{Possibilidade de crescimento (importância social do segmento e capacidade de desenvolvimento tecnológico)}

A aplicação deste critério supõe a seguinte pergunta básica: Quais são as possibilidades de progressão da atividade no futuro:

- $\quad$ em função dos fatores de risco (idade, sexo, grupo social, situação epidemiológica...)

- $\quad$ em função da evolução tecnológica ou do savoir-faire (novas terapêuticas)? Aqui deve-se considerar o potencial de crescimento teórico em função dos cenários epidemiológico e tecnológico que condicionam a demanda potencial. Restrições ao crescimento como a capacidade instalada, os equipamentos e outros deveriam ser contempladas por referência a outros critérios.

Nota alta: Forte crescimento

Nota baixa: Diminuição importante

\section{Intensidade da concorrência}

Neste caso, trata-se de saber a quantidade de concorrentes existentes na área de referência. Perguntas como as seguintes devem ser formuladas: Quantas instituições públicas e privadas exercem uma atividade similar na zona de influência do hospital? Qual é a sua contribuição à rede de cuidados (o que fazem)? Quantos concorrentes estão já instalados? Quais são seus meios materiais e financeiros? Qual é a previsão da instalação de novos concorrentes?

Nota forte: poucos concorrentes

Nota baixa: muitos concorrentes 


\section{Investimento (como barreira à entrada)}

Aqui procuramos saber se o investimento necessário (em instalações, equipamentos e competências médicas específicas) para ser competitivo no segmento específico constitui ou não uma barreira à nossa entrada a à de concorrentes eventuais. Quando o tamanho do investimento a ser feito é grande e não há previsão (ou condições) de realizá-lo, considera-se difícil penetrar no segmento ou continuar a desenvolvê-lo. Neste caso, de não controle de um investimento necessário elevado, haveria uma desvalorização do segmento no tocante a este critério. Em relação a este critério, teria de ser dada uma nota baixa ao segmento. Quando se considera que não haveria barreiras à nossa entrada pelo fato de controlarmos o investimento necessário elevado, a nota a ser dada teria de ser forte. Neste caso, o grande investimento realizado e a ser complementado no futuro opera como uma vantagem competitiva nossa e como eventual barreira á entrada de concorrentes.

Nota alta: Investimento necessário elevado controlável

Nota baixa: Investimento necessário fracamente controlável

Quando o investimento necessário não é considerável (não constitui uma barreira) e é controlado por nós, prefere-se uma nota mais intermediária, menor relativamente à nota dada a um tipo de investimento necessário elevado controlado. Isto porque, nesse caso, todos podem realizar com facilidade o investimento necessário, isto é, o tamanho do investimento necessário não é barreira à entrada dos outros, configurando-se uma situação em que nosso nível de investimento não representa uma provável vantagem comparativa.

\section{Sinergias}

Procura-se saber:

- se, no nível da atividade, existe (ou poderia existir) alguma forma de integração ou de política de colaboração com outros serviços do hospital (competências compartilhadas);

- $\quad$ se, no nível da atividade, é possível a utilização em comum de locais e de meios logísticos com outros serviços (do hospital).

Nota alta: colaboração elevada/equipamentos e infra-estruturas compartilhados

Nota baixa: não colaboração/não há utilização comum 


\section{Motivação interna}

Interessa a vocês particularmente a atividade do segmento? Estão vocês dispostos a transferir recursos para desenvolver estas atividades? Há um nível de comprometimento razoável em relação ao segmento?

Nota forte: motivação forte

Nota baixa: motivação fraca

\section{Possibilidades de parceria externa}

A atividade permite estabelecer uma rede de colaboração com instituições ou profissionais externos ou com outros especialistas da disciplina específica? (incluir aqui os serviços que referem pacientes para o hospital).

Nota alta: potencial elevado

Nota baixa: não colaboração prevista

\section{Potencial regional}

Este segmento compreende uma atividade importante de atração de clientela municipal?

Nota alta: poder de atração municipal ou estadual

Nota baixa: poder de atração somente local (área)

\section{Potencial local}

O segmento desenvolve uma atividade local importante (dentro da área programática)?

Nota alta: forte poder de atração local

Nota baixa: fraco poder de atração local

\section{Potencial de ensino e pesquisa}

Este segmento compreende um volume de atividade importante de ensino e de pesquisa?

Nota alta: atividade de ensino e pesquisa

Nota baixa: rotina 


\section{Contribuição para o projeto político (ou para o projeto de missão) do hospital}

Em que medida o desenvolvimento do segmento é coerente com a definição geral da missão do hospital? O desenvolvimento do segmento foi pensado como prioritário para o projeto geral defendido para o hospital? Neste caso, considerar a natureza do Hospital - se é geral, especializado ou uma combinação de ambos.

Nota alta: segmento funcional ao projeto geral de missão

Nota baixa: segmento redundante, não prioritário

\section{Contribuição para a imagem externa}

Este segmento permite criar ou desenvolver uma imagem positiva diante da ambiência (sistema de referência, redação de jornais científicos, grande público, decisores locais...)?

Nota alta: contribuição à imagem forte

Nota baixa: sem impacto sobre a imagem

Os técnicos franceses utilizam outros critérios eventuais:

- Capacidade de transferir tecnologia

- Capacidade de incorporação tecnológica através de uma parceria com centros de ponta

- Capacidade de trazer recursos externos

- Custo variável da atividade (nota alta para um custo relativamente menor)

O investimento poderia ser desdobrado em equipamentos/tecnologia, recursos humanos especializados e capacidade instalada (o que corresponderia a trabalhar com três subcritérios).

$\mathrm{O}$ potencial de pesquisa e ensino também podem ser separados.

Cada critério tem um peso percentual (p) definido anteriormente. Este peso percentual corresponderia ao grau de aplicabilidade, à importância ou à pertinência de cada critério em função das características concretas da Especialidade, tais como a natureza político-administrativa do hospital onde se insere, o nível de complexidade, o nível de concorrência na área, a visão política da direção estratégica, etc. Este peso é dado situacionalmente pelo grupo em função da Especialidade e é um peso uniforme para todos os Segmentos da Especialidade. A cada critério corresponde uma nota de 0/20 (n), dado a cada Segmento da Especialidade. O valor global do segmento dependerá dos scores específicos, é o somatório dos mesmos ( $\mathrm{S}=\mathrm{p} \times \mathrm{n})$. 
Na definição do peso (ou distribuição de 100 pontos pelos critérios), algumas perguntas podem ser formuladas:

- O crescimento é um objetivo que faça parte de seu projeto de trabalho? Em que medida se espera um crescimento relevante ou não da especialidade no futuro?

- Em que medida a concorrência afeta a sua especialidade? Aplica-se este critério a sua realidade? Quando não há muita concorrência, é indicado atribuir pouco peso ao critério. Correlativamente, o critério possibilidade de crescimento pode ganhar mais importância.

- O investimento necessário à sua especialidade é elevado? (em tese, não importa se você o controla ou não). Priorize equipamentos e tecnologias. Quando a especialidade não precisa de um investimento muito elevado (pouco peso), pode ganhar importância relativa o fator motivação dos recursos humanos.

- O potencial de sinergias e parceiras externas é elevado? Ou a sua especialidade dispensa ou precisa de poucas sinergias e parcerias?

- Que tipo de potencial de atração de clientela a sua especialidade prioriza?

- Em que medida a sua especialidade é vista pela direção estratégica como um dos carros-chefe do Hospital? Sua especialidade contribui de maneira decisiva para melhorar a imagem externa do hospital?

- As atividades de ensino e de pesquisa adquirem relevância dentro da especialidade?

\section{Análise da Posição Competitiva (da Detenção dos Fatores Estratégicos de Êxito) do Segmento (formato II)}

\section{Consiste em:}

- Listar de 5 a 10 (sem rigidez) fatores estratégicos de êxito do segmento em pauta. São vantagens, condições positivas para desempenhar com êxito a atividade.

São exemplos: a existência de um bom sistema de emergência que atenda no domicílio e nas ruas, para a Neurologia, onde o fator tempo é essencial no transporte de pacientes; um bom relacionamento com profissionais e instituições da rede, capazes de encaminhar pacientes; um bom sistema de acolhimento, aumentando a qualidade de atendimento; a disponibilidade de equipamentos, como um tomógrafo computadorizado; um bom sistema laboratorial; etc. 
São condições cuja posse permite discriminar entre estabelecimentos em termos de posição de vanguarda. Em geral, são capacidades ou competências profissionais, capacidades tecnológicas e financeiras, relacionais, de efeito discriminante. Estas condições ou recursos não são necessariamente controlados por nós. São fatores necessários idealmente ao desenvolvimento de um tipo de atendimento de alto nível de qualidade, de ponta.

- Avaliar, dando nota $(0 / 20)$, o grau de controle de cada um destes fatores por parte do hospital.

- Estimar o valor global da posição competitiva do segmento, considerando que a cada fator deve ser atribuído um peso $(\%)$ determinado.

- Fazer o mesmo em relação aos concorrentes.

\section{Porta-Fólio de Atividades (formato 12)}

É um gráfico cuja abcissa corresponde à posição competitiva, e a ordenada, ao valor dos segmentos. Os segmentos são posicionados neste gráfico, dividido em quatro quadrantes. A partir da análise do porta-fólio deve ser definida a estratégia que consiste em estabelecer três possibilidades de objetivos por segmento:

- desenvolver, priorizar um segmento;

- estabilizar um segmento;

- diminuir o recrutamento de clientela para um segmento (formato 13).

O porta-fólio permite uma visão de conjunto da especialidade, comparar a posição estratégica dos segmentos e estabelecer prioridades entre os mesmos. Ele deveria dar lugar a uma reflexão sobre o plano de desenvolvimento específico de cada segmento, sobre o tipo de estratégia a ser seguida em cada caso: diferenciação; custos e/ou focalização de atividades.

\section{O Plano de Ação (formato 14)}

Inclui as atividades visando ao cumprimento da estratégia derivada da análise do portafólio. Precisa recursos, produtos, resultados e indicadores de acompanhamento das ações.

Mais considerações sobre Estratégia e Plano: 
Tipos de estratégia:

- Desenvolver um segmento: identificar as atividades que deve ser expandidas, priorizadas, desenvolvidas particularmente. Este objetivo em geral se confunde com a estratégia de diferenciação ou de agregação de um plus de valor percebido como melhora de qualidade, podendo implicar mais custos, em investimentos específicos para enfrentar os pontos fracos típicos dos FCS. O desafio, aqui, seria buscar a estratégia de diferenciação que envolvesse relativamente menos custos.

- Manter ou estabilizar um segmento: definir os segmentos que devem ser mantidos em "banho-maria", no mesmo nível de desenvolvimento histórico, se possível reduzindo custos. Aqui podem constar segmentos de alta competitividade e valor, os quais poderiam ser apenas mantidos na atual posição, reduzindo custos e liberando recursos para outras atividades.

- Reduzir o recrutamento da clientela para um segmento: definir quais segmentos seria necessário recortar ou focalizar, desestimular, diminuir, negociando a transferência parcial ou total de atividades para a rede (entende-se por focalização privilegiar um determinado tipo de usuário ou nosologia).

Para Porter (1982), haveria três estratégias genéricas, maisbem discutidas adiante a partir da obra de Crémadez \& Grateau (1997): diferenciação, que implicaria definir uma oferta única, exclusiva, diferenciada, percebida por todos como superior qualitativamente, cujo acesso também poderia ser diferenciado; liderança no custo, que representaria diminuir custos para liberar recursos para outros segmentos, sem comprometer a qualidade; focalização (que pode cursar como estratégia de custos e/ou diferenciação).

\section{Elaboração dos Planos de Ação}

Os planos incluem os esforços a serem realizados para agir sobre a rede de médicos de consultório (que referem pacientes), para implementar associações, para formar médicos e pessoal paramédico, para comunicar o savoirfaire controlado, para adquirir novas tecnologias, para implementar novos modos de atenção etc.

O Plano de Ação é o 'que fazer' para implementar a Estratégia. Consistiria em um conjunto de atividades, tais como:

- Formas de apropriação/desenvolvimento dos fatores-chave de sucesso visando a enfrentar os pontos fracos identificados na análise incorporação de tecnologias e de recursos humanos, treinamentos, desenvolvimento de fatores de qualidade etc. 
- Ações de negociação e de comunicação internas ao hospital e com a rede, incluindo o estabelecimento de sinergias e parcerias externas.

- Ações visando a revalorizar um segmento, a intervir sobre algum critério da análise do valor de baixo score, passível de intervenção (quando a decisão política é de buscar aumentar o valor).

- Ações visando a modificar o modelo assistencial, as formas de atendimento que caracterizam um determinado segmento, o perfil de tecnologias utilizadas.

- Ações de natureza social e intersetorial.

- Ações que desenvolvam objetivos tipicamente médicos, como determinadas pesquisas.

A consolidação de um plano de ação é um contínuo retomar da análise estratégica do valor e da posição competitiva, visando aumentar o controle dos FCS, para melhorar a posição estratégica geral.

O plano culmina com a definição dos indicadores de monitoramento das ações para que seja possível acompanhar as mudanças propostas. 
Formato 1

Descrição das Atividades

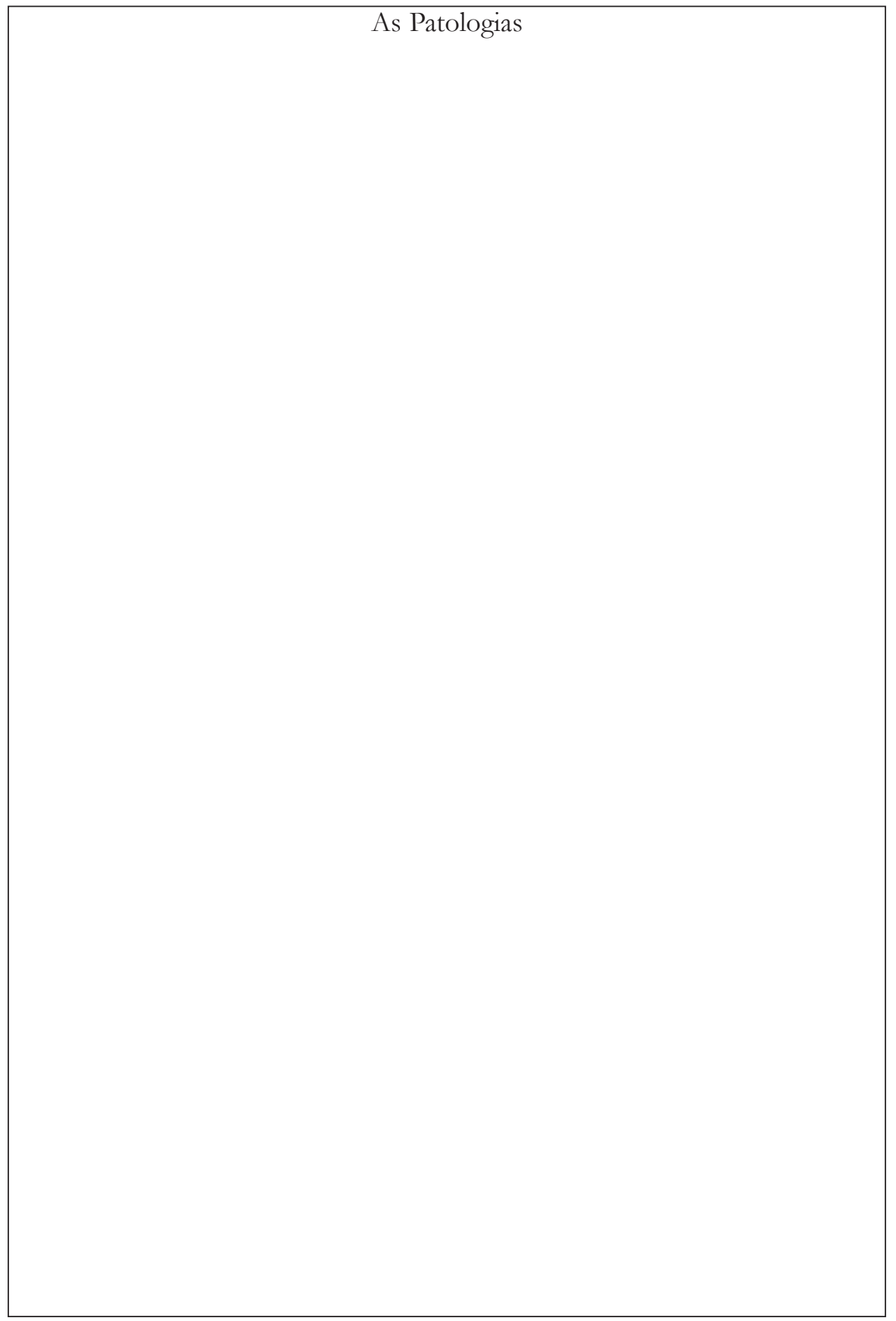


Formato 2

Descrição das Atividades

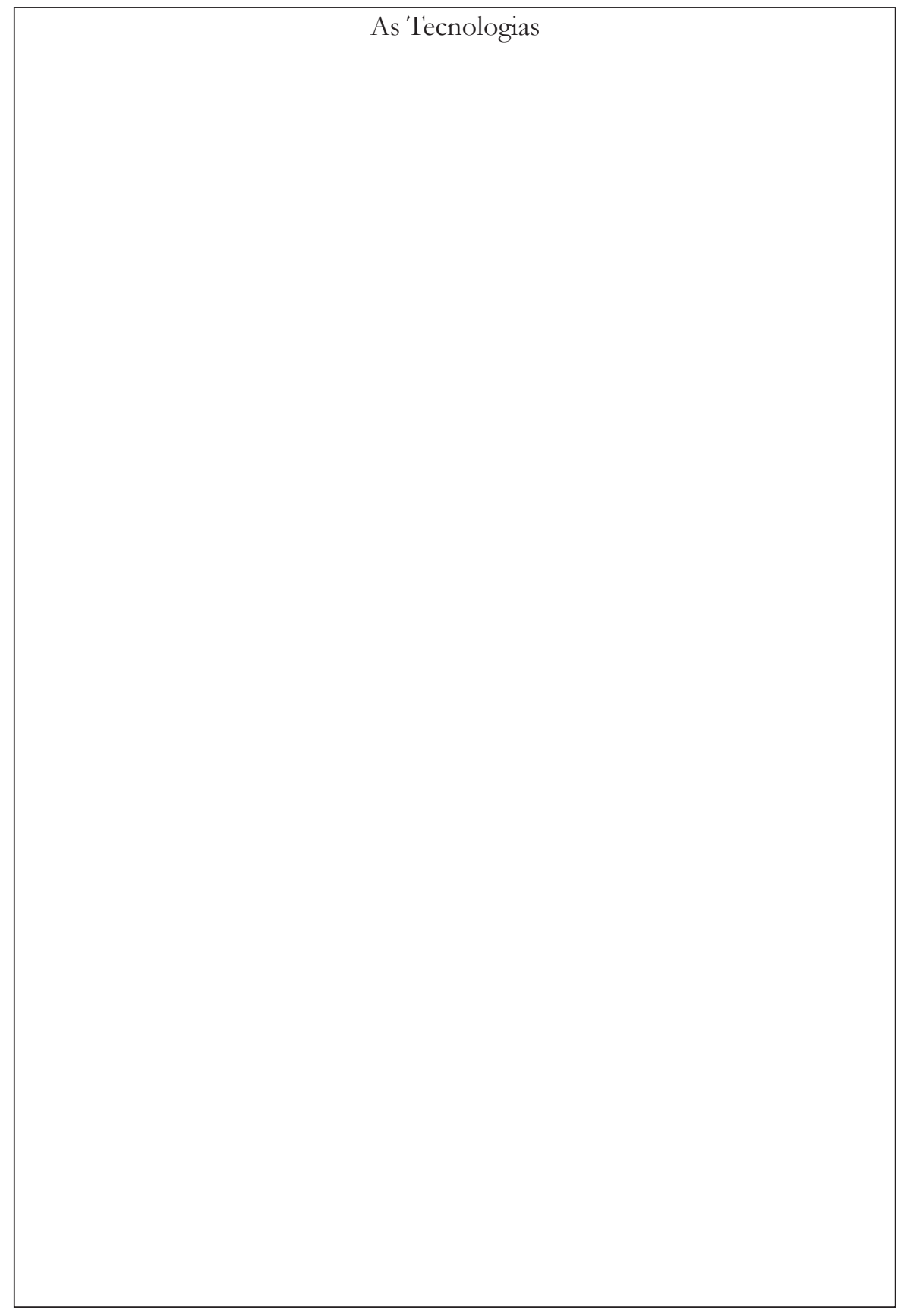


Formato 3

Quadro da Oferta de Atividades 1 (por especialidade)

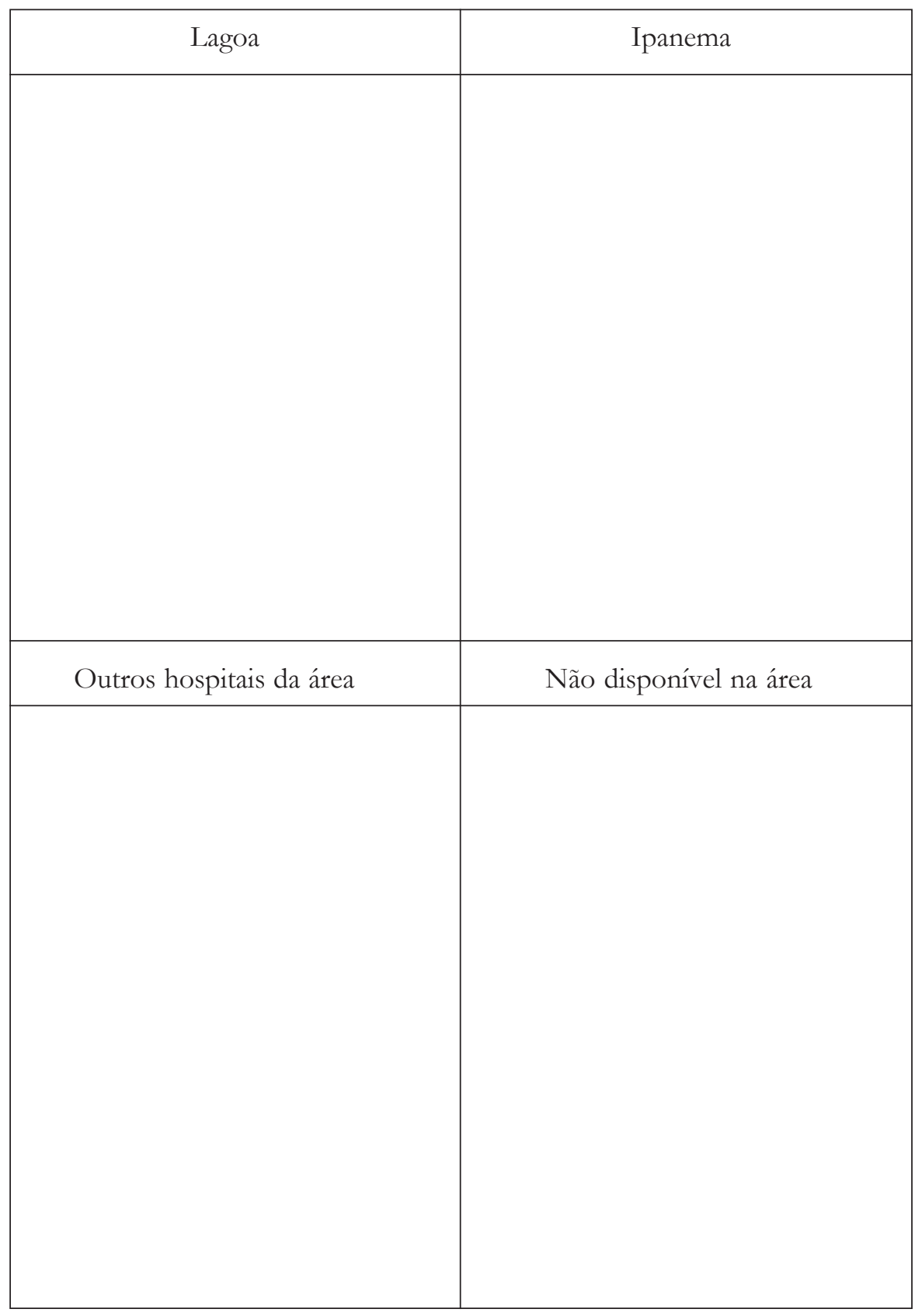


Formato 4

Quadro da Oferta de Atividades 2 (por especialidade)

\begin{tabular}{|l|l|}
\hline Comum hospital/concorrência & Específico à concorrência \\
\hline Específico ao hospital & \\
\hline & \\
\hline & \\
\hline & \\
\hline
\end{tabular}


Formato 5

Matriz Patologias/Tecnologias

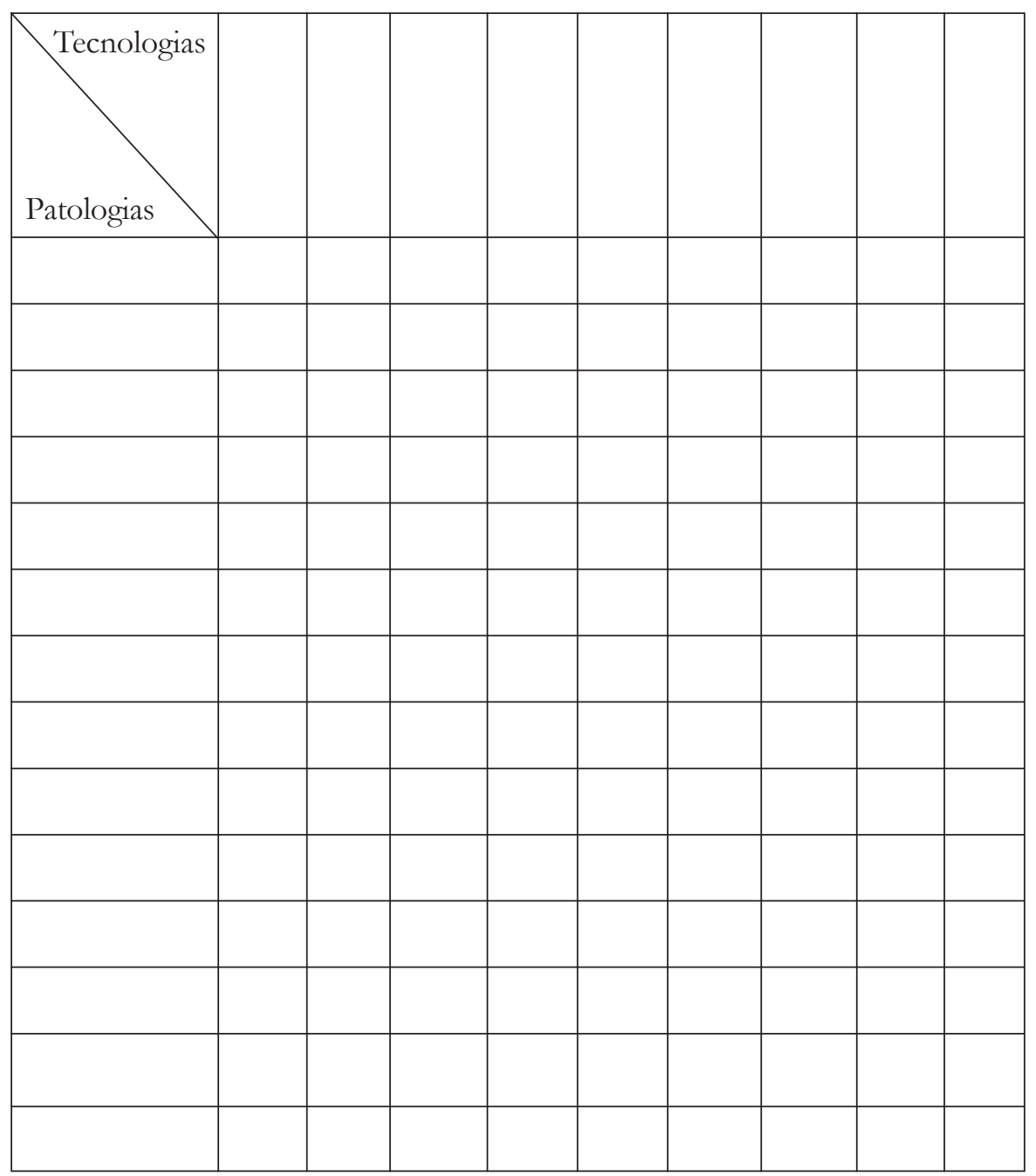

Classificar as tecnologias, utilizando os seguintes símbolos:

D - Tecnologia utilizada no diagnóstico e/ou no acompanhamento

$\mathrm{T}$ - Tecnologia utilizada no tratamento

Poderá incluir também a freqüência da utilização da tecnologia

$\mathrm{D}+/ \mathrm{T}+$ - Utilização quase sistemática

$\mathrm{D} \pm / \mathrm{T} \pm$ - Utilização freqüente (ao redor de $50 \%$ )

D-/T - Utilização excepcional 
Formato 6

Matriz de Segmentação de Patologias

\begin{tabular}{|c|c|c|c|c|}
\hline Componentes & 1)E/NE & 2) $\mathrm{H} / \mathrm{NH}$ & 3) $\mathrm{D} / \mathrm{S} / \mathrm{SS} / \mathrm{P}$ & 4)IN/SH/EX \\
\hline & & & & \\
\hline & & & & \\
\hline & & & & \\
\hline & & & & \\
\hline & & & & \\
\hline & & & & \\
\hline & & & & \\
\hline & & & & \\
\hline & & & & \\
\hline & & & & \\
\hline & & & & \\
\hline
\end{tabular}

1) Eletivo/Não-Eletivo

2) Necessidade de Hospitalização (Hospitalização/Não Hosp.)

3) Duração da Hospitalização (dia (D), semanal (S), até duas semanas (SS), prolongada (P))

4) Disponibilidade interna ou externa (à especialidade) das tecnologias necessárias ou implementadas. 
Formato 7

Matriz de Segmentação de Tecnologias

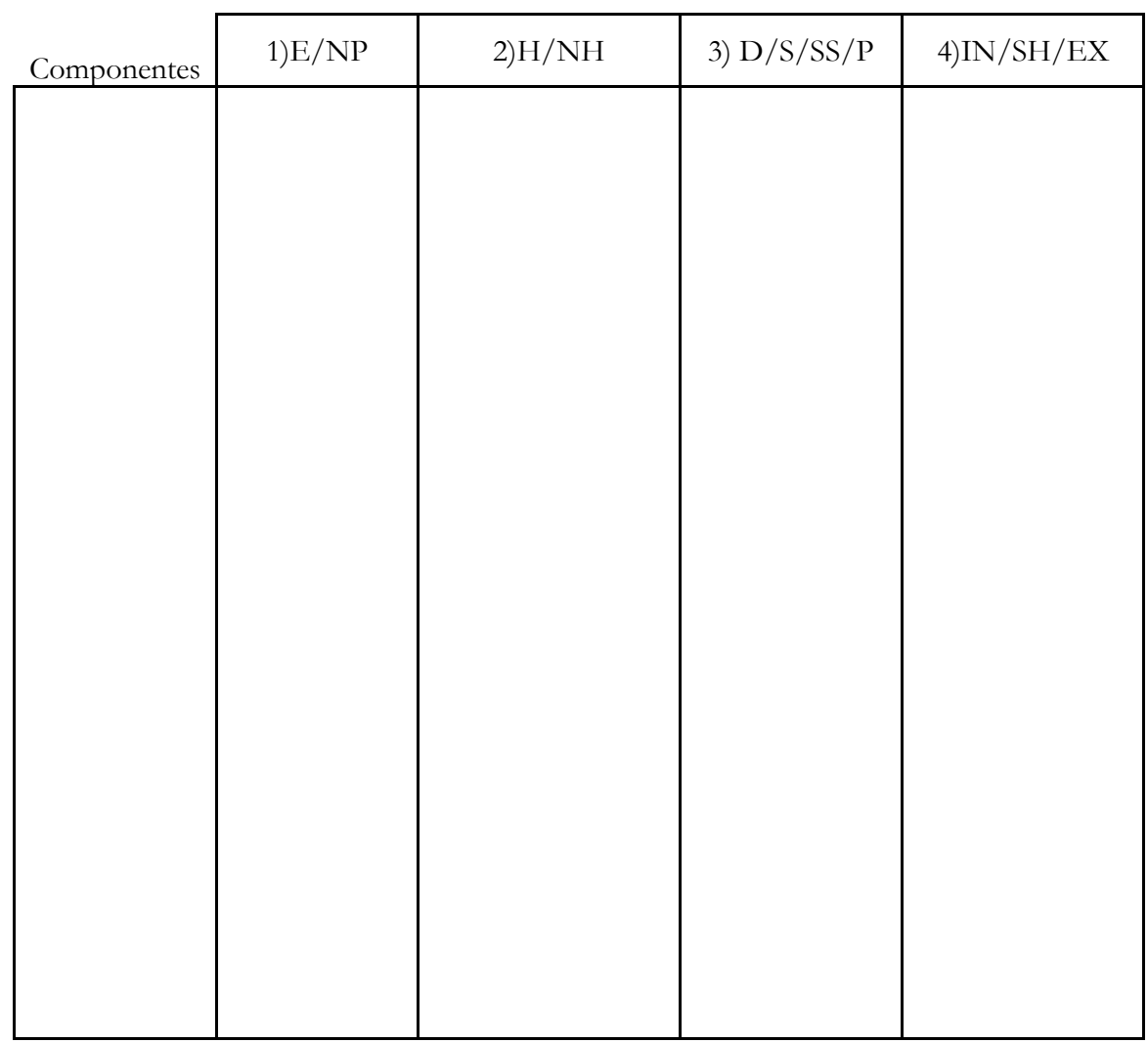

1) Eletivo/Não-Eletivo

2) Necessidade de Hospitalização (Hospitalização/Não Hosp.)

3) Duração da Hospitalização (dia (D), semanal (S), até duas semanas (SS), prolongada $(\mathrm{P}))$

4) As tecnologias necessárias estão disponíveis no Serviço (IN), no Hospital (SH) ou externamente (EX) 
Formato 8

Segmentação Estratégica

Serviço:

Segmentos:

1)

2)

3)

4) 
Formato 9

Quadro de Parceiros e Concorrentes (por segmento)

\begin{tabular}{|c|c|c|}
\hline Instituição & $\mathrm{P}$ & $\mathrm{C}$ \\
\hline & & \\
\hline & & \\
\hline & & \\
\hline & & \\
\hline & & \\
\hline & & \\
\hline & & \\
\hline & & \\
\hline & & \\
\hline & & \\
\hline & & \\
\hline & & \\
\hline & & \\
\hline & & \\
\hline & & \\
\hline & & \\
\hline & & \\
\hline
\end{tabular}

Parceiros: $\mathrm{P}$

Concorrentes: $\mathrm{C}$ 
Formato 10

Avaliação do Valor (Capacidade de Atração) do Segmento

\begin{tabular}{|l|c|c|c|}
\hline \multicolumn{1}{|c|}{ Critérios de avaliação } & $\begin{array}{c}\text { Peso } \\
\%\end{array}$ & $\begin{array}{c}\text { Nota } / \\
20\end{array}$ & $\begin{array}{c}\text { Score } \\
(=\mathrm{p} \text { x n })\end{array}$ \\
\hline Possibilidades de crescimento & & & \\
\hline Intensidade da concorrência & & & \\
\hline Investimento (barreiras à entrada) & & & \\
\hline $\begin{array}{l}\text { Sinergias (no nível de competências e infraestruturas } \\
\text { compartilhadas) }\end{array}$ & & & \\
\hline Motivação interna & & & \\
\hline Possibilidades parceria externa & & & \\
\hline Potencial regional & & & \\
\hline Potencial local & & & \\
\hline Potencial de ensino e pesquisa & & & \\
\hline Contribuição para o projeto político geral do hospital & & & \\
\hline Contribuição para a imagem externa & & & \\
\hline
\end{tabular}

Valor Segmento

100

0,0 


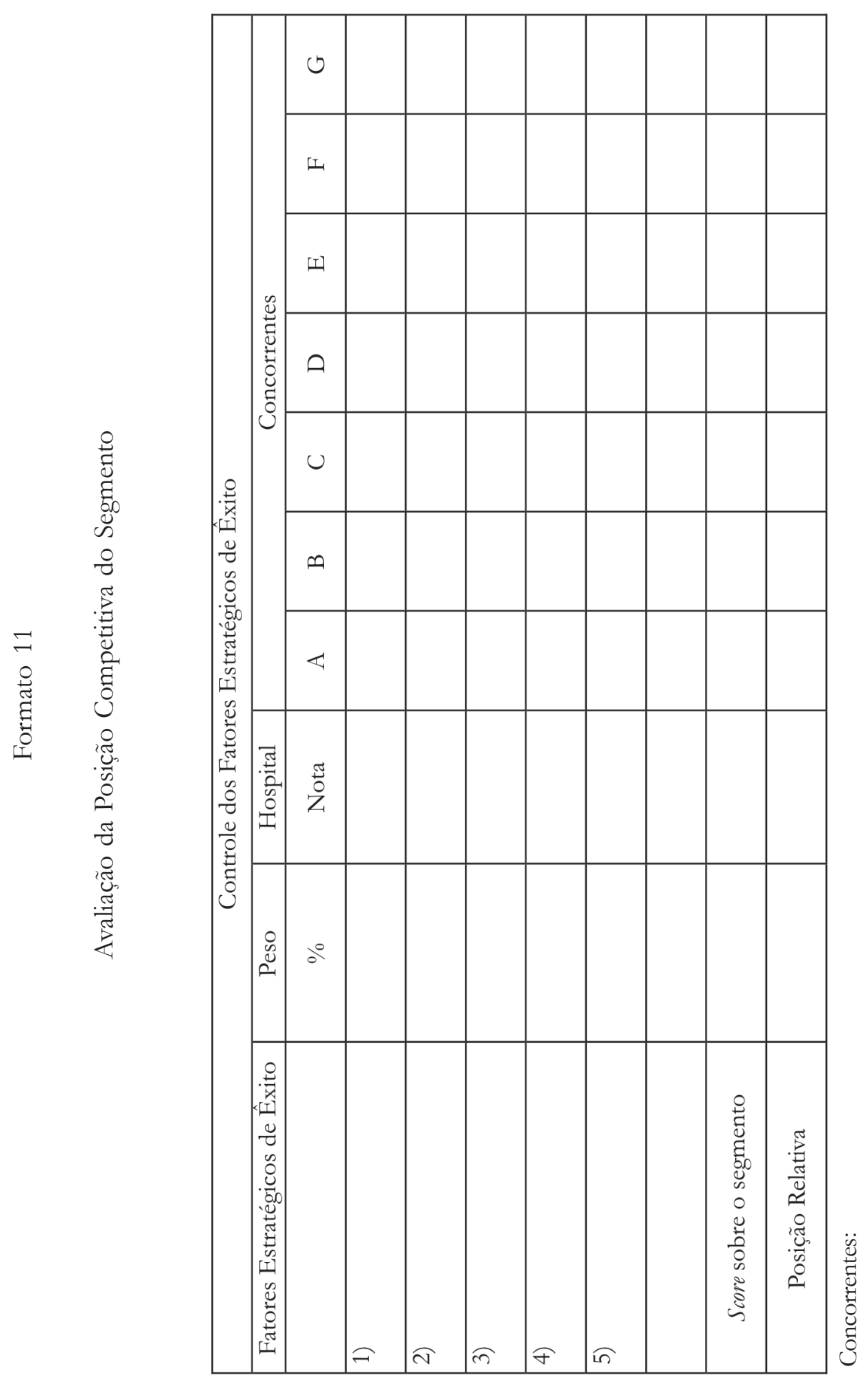


Formato 12

Porta-Fólio de Atividades

Serviço ou Especialidade

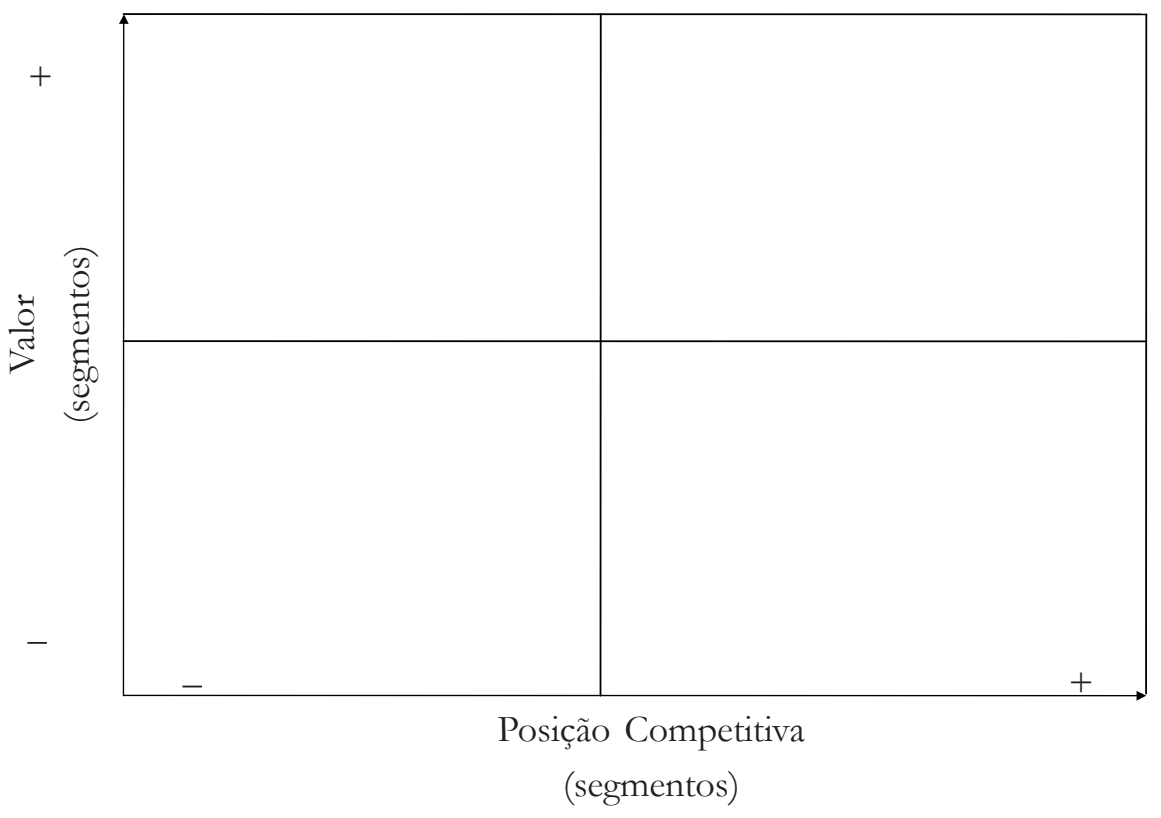


Formato 13

Estratégia de Atuação (Objetivos)

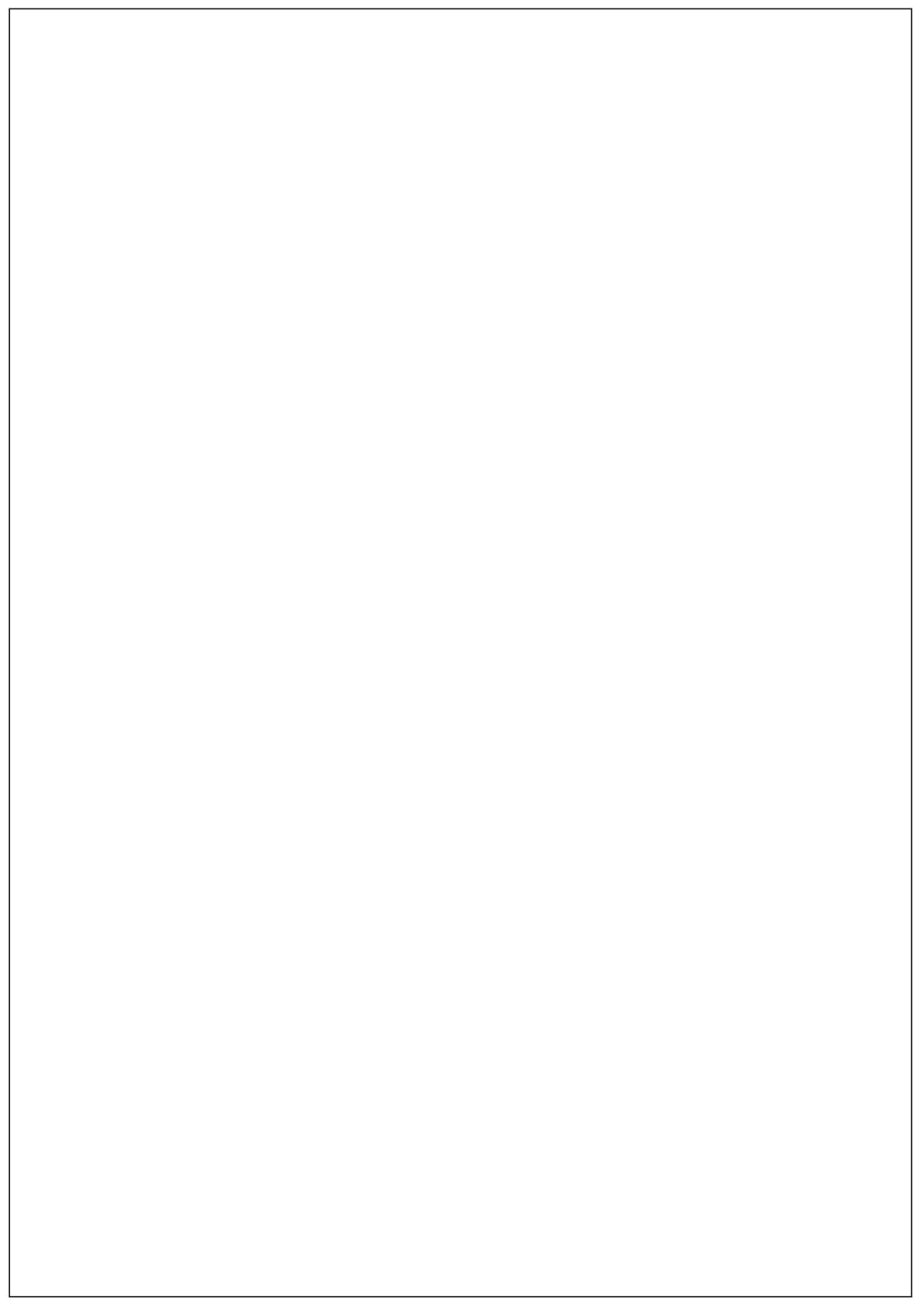




$$
\tilde{I I I I}
$$




Formato: $16 \times 23 \mathrm{~cm}$

Tipologia: Garamond

Papel: Pólen bold $70 \mathrm{~g} / \mathrm{m}^{2}$ (miolo)

Cartão supremo $250 \mathrm{~g} / \mathrm{m}^{2}$ (capa)

Fotolitos: Laser vegetal (miolo)

Engenho \& Arte Editoração Gráfica Ltda. (capa)

Impressão e acabamento: Millennium Print Comunicação Visual Ltda.

Rio de Janeiro, junho de 2003.

Não encontrando nossos títulos em livrarias, contactar a EDITORA FIOCRUZ:

Av. Brasil, 4036 - 1o andar - sala 112 Manguinhos

21040-361 - Rio de Janeiro - RJ.

Tel.: (21) 3882-9039 e 3882-9041

Telefax: (21) 3882-9006

http://www.fiocruz.br/editora

E-mail: editora@fiocruz.br 